\title{
₹USGS
}

science for a changing world

Prepared in cooperation with the U.S. Fish and Wildifie Serviee

Scjence to Support Adaptive Habjtat llanagement: Overton Botfoms IJorth Unit, Bitg JلJuddy National

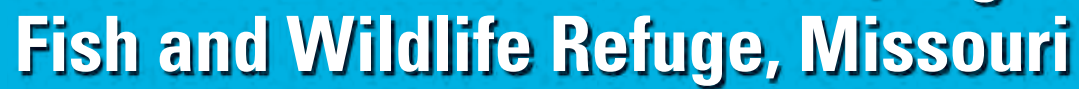

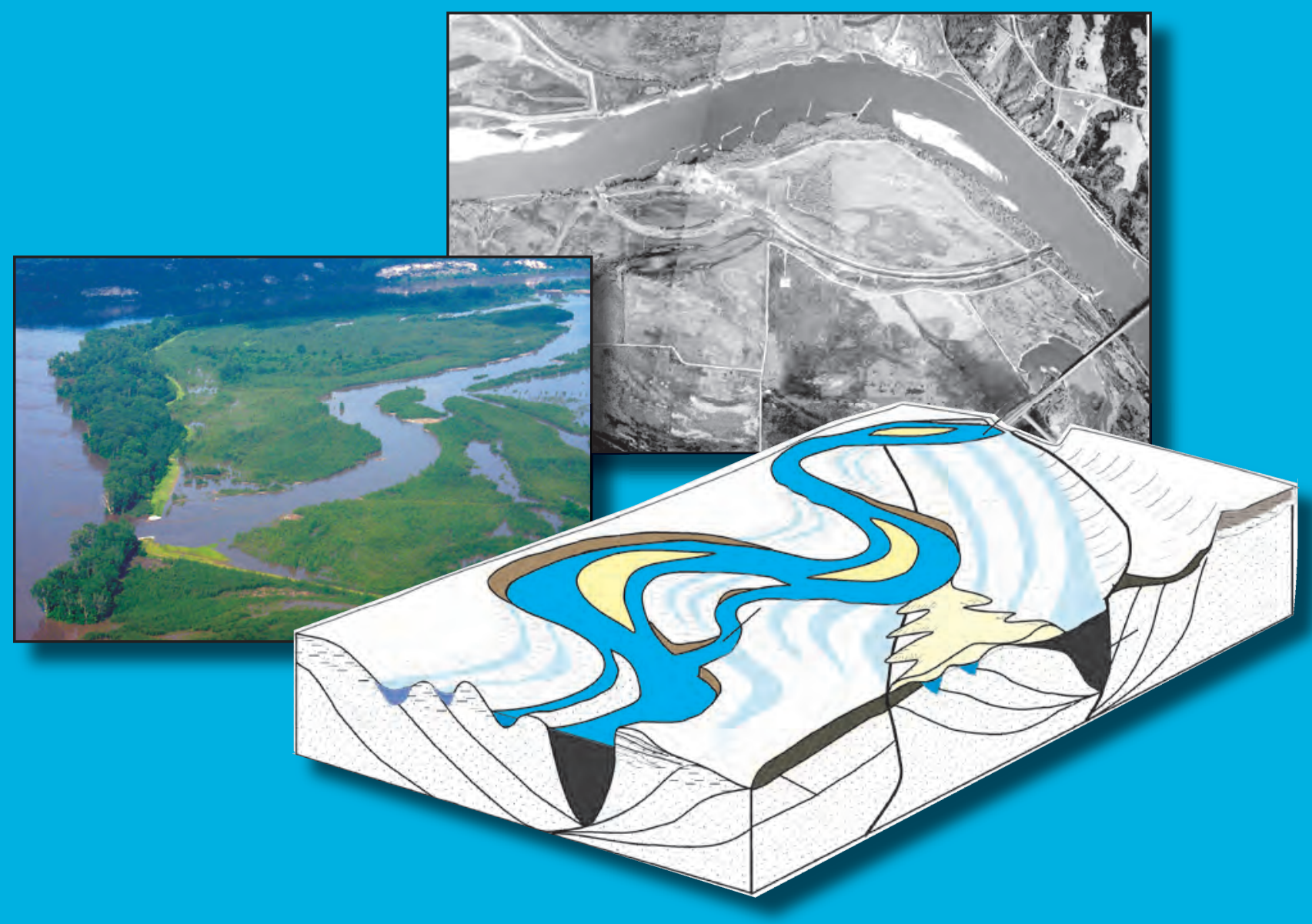

Scientific Investigations Report 2006-5086 
Cover: Top-Areal view of Overton Bottoms North Unit, Big Muddy National Fish and Wildlife Refuge, Missouri; Left-Areal view of the first-generation side-channel chute at Overton Bottoms North Unit; Right-Architecture of the Lower Missouri River Valley bottom. 


\section{Science to Support Adaptive Habitat Management: Overton Bottoms North Unit, Big Muddy National Fish and Wildlife Refuge}

Edited by Robert B. Jacobson

Volume comprises Chapters 1, 2, 3, 4, 5, and 6

Prepared in cooperation with the U.S. Fish and Wildlife Service

Scientific Investigations Report 2006-5086 


\section{U.S. Department of the Interior \\ P. Lynn Scarlett, Acting Secretary}

\section{U.S. Geological Survey \\ P. Patrick Leahy, Acting Director}

U.S. Geological Survey, Reston, Virginia: 2006

For product and ordering information:

World Wide Web: http://www.usgs.gov/pubprod

Telephone: 1-888-ASK-USGS

For more information on the USGS--the Federal source for science about the Earth, its natural and living resources, natural hazards, and the environment:

World Wide Web: http://www.usgs.gov

Telephone: 1-888-ASK-USGS

Any use of trade, product, or firm names is for descriptive purposes only and does not imply endorsement by the U.S. Government.

Although this report is in the public domain, permission must be secured from the individual copyright owners to reproduce any copyrighted materials contained within this report.

Suggested citation:

Jacobson, R.B., ed., 2006, Science to support adaptive habitat management-Overton Bottoms North Unit, Big Muddy National Fish and Wildlife Refuge, Missouri: U.S. Geological Survey, Scientific Investigations Report 2006-5086, 116 p. 


\section{Foreword}

Many of the current issues faced by land and water management agencies are complex and often have resulted from past management practices and the competition among users for limited resources. Decisions about resource use often require an understanding of the potential results of alternative management actions. This understanding is based upon knowledge about the interactions of the many components which make up a watershed or ecosystem, and the science necessary to develop this foundation requires experts from many disciplines working together. At USGS, our mission to provide reliable scientific information is enhanced through this interdisciplinary approach to science problems and provides managers with a more complete understanding on which to base their decisions. This report is the result of applying an interdisciplinary approach to the issues of ecosystem function in the channel and flood plain of the Lower Missouri River.

Thomas J. Casadevall

Regional Director, Central Region

U.S. Geological Survey

\section{Acknowledgements}

The authors thank the U.S. Fish and Wildlife Service, Big Muddy National Fish and Wildlife Refuge (Refuge) for access to the Overton Bottoms North Unit. Our work on the Refuge was facilitated by Thomas Bell, Refuge Manager, and Maureen Gallagher, who was the Refuge Biologist during this study. We also benefited from access to adjacent areas of Overton Bottoms managed by the Missouri Department of Conservation. Many of the ideas in this report developed through numerous discussions with scientists and managers working on the Lower Missouri River. In particular, the authors benefited from discussions and coordination with staff from the Kansas City District, U.S. Army Corps of Engineers, and the departments of Forestry, and Fish and Wildlife, University of Missouri. Dale Blevins, Milan Pavich, Randy Orndorff, and Pamela Haverland, helped in planning, executing, and publishing the project. Peer reviews of chapters were graciously provided by Wedge Watkins, Margaret Guccione, Richard Langford, Scott Lundstrom, Jonathan Friedman, Esther Stroh, David Galat, Carl Korschgen, Michael Starbuck, Gary Krizanich, Mike Kleeschulte, and Robert Buchmiller. Jeanne Heuser and Katherine Laub provided copyediting, and Jeanne Heuser prepared the report for publication. This project could not have been completed without the funding support from the USGS Central Region Integrated Science Program (CRISP) and other USGS Bureau Programs. 


\section{Volume Contents}

1. Introduction: Science to Support Adaptive Habitat Management, Overton Bottoms North Unit, Big Muddy National Fish and Wildlife Refuge, Missouri 1

by Robert B. Jacobson

2. Surficial Alluvium and Topography of the Overton Bottoms North Unit, Big Muddy National Fish and Wildlife Refuge in the Missouri River Valley and its Potential Influence on Environmental Management

by John Holbrook, Greg Kliem, Chima Nzewunwah, Zen Jobe, and Ron Goble

3. Hydrologic Interactions Among Rainfall, Side-Channel Chutes, the Missouri River, and Ground Water at Overton Bottoms North, Missouri, 1998-2004

by Brian P. Kelly

4. Retrospective Analysis of Land Cover at Overton Bottoms, Missouri by Jeffrey D. Spooner and Keith F. Landgraf

5. Cottonwood (Populus deltoides) Growth Response to Hydrologic Alteration, Overton Bottoms North, Missouri River Flood Plain 91

by Thomas M. Faust, Robert B. Jacobson, and Stephen G. Pallardy

6. Implications for Adaptive Habitat Management of the Overton Bottoms North Unit, Big Muddy National Fish and Wildlife Refuge, Missouri

by Carol A. Finn and Robert B. Jacobson

Glossary and Acronyms

\section{Conversion Factors}

\begin{tabular}{|c|c|c|}
\hline Multiply & By & To obtain \\
\hline \multicolumn{3}{|c|}{ Length } \\
\hline centimeter $(\mathrm{cm})$ & 0.3937 & inch (in) \\
\hline meter $(\mathrm{m})$ & 3.281 & foot (ft) \\
\hline kilometer $(\mathrm{km})$ & 0.6214 & mile (mi) \\
\hline \multicolumn{3}{|c|}{ Area } \\
\hline hectare (ha) & 2.471 & acre (ac) \\
\hline hectare (ha) & 0.003861 & square mile $\left(\mathrm{mi}^{2}\right)$ \\
\hline square mile $\left(\mathrm{mi}^{2}\right)$ & $2.590 \times 10^{0}$ & square kilometer $\left(\mathrm{km}^{2}\right)$ \\
\hline square kilometer $\left(\mathrm{km}^{2}\right)$ & 247.1 & acre (ac) \\
\hline square kilometer $\left(\mathrm{km}^{2}\right)$ & 0.3861 & square mile $\left(\mathrm{mi}^{2}\right)$ \\
\hline acre-foot (acre-ft) & $1.223 \times 10^{-6}$ & cubic kilometer $\left(\mathrm{km}^{3}\right)$ \\
\hline \multicolumn{3}{|c|}{ Flow rate } \\
\hline cubic meters per second $\left(\mathrm{m}^{3} / \mathrm{s}\right)$ & 35.31 & cubic foot per second $\left(\mathrm{ft}^{3} / \mathrm{s}\right)$ \\
\hline
\end{tabular}




\section{Introduction: Science to Support Adaptive Habitat Management, Overton Bottoms North Unit, Big Muddy National Fish and Wildlife Refuge, Missouri}

By Robert B. Jacobson

Chapter 1 of

Science to Support Adaptive Habitat Management: Overton Bottoms North Unit, Big Muddy National Fish and Wildlife Refuge, Missouri

In cooperation with the U.S. Fish and Wildlife Service

Scientific Investigations Report 2006-5086 


\section{Contents}

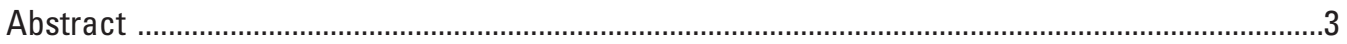

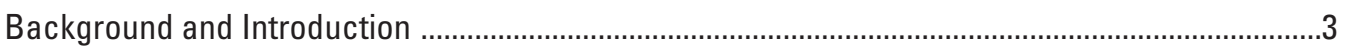

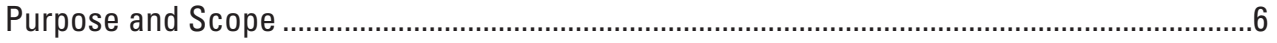

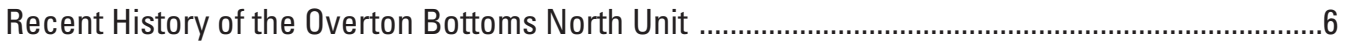

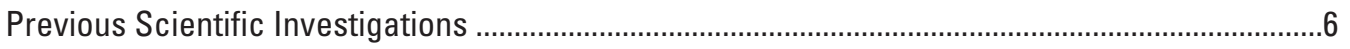

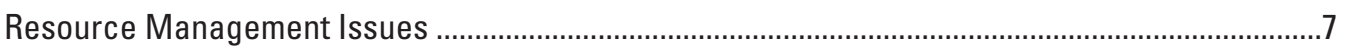

Overton Bottoms North Unit Case Study .........................................................................

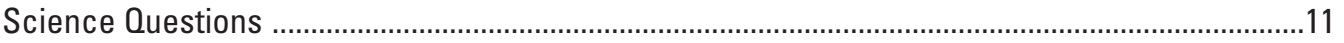

Surficial Geologic Framework ........................................................................................11

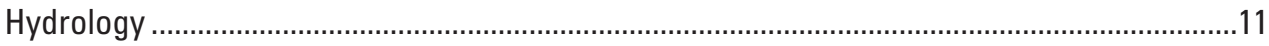

Selected Ecological Responses .....................................................................................12

The Role of Science in Adaptive Resource Management ........................................................12

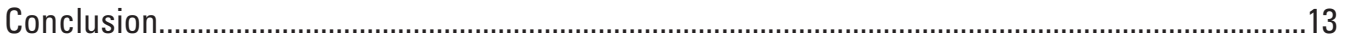

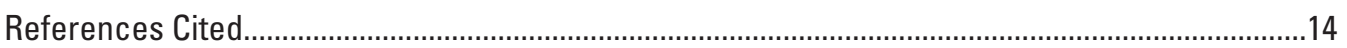

\section{Figures}

\section{1-2. Maps showing-}

1. The Lower Missouri River ....................................................................................

2. The location of the Overton Bottoms North Unit ...................................................

3. Hydrograph of the Missouri River at Boonville, Missouri, 1992-2005...............................7

4. Map showing the locations of the side-channel chutes ...............................................

5. Map, photograph, and graphs of chute re-excavation ...............................................10

6. Schematic showing conceptual model of water levels and tree growth .......................13

\section{Tables}

1. Types of rehabilitation activities in the Lower Missouri River corridor .8 


\title{
Chapter 1 \\ Introduction: Science to Support Adaptive Habitat Management, Overton Bottoms North Unit, Big Muddy National Fish and Wildlife Refuge, Missouri
}

\author{
By Robert B. Jacobson
}

\section{Abstract}

Extensive efforts are underway along the Lower Missouri River to rehabilitate ecosystem functions in the channel and flood plain. Considerable uncertainty inevitably accompanies ecosystem restoration efforts, indicating the benefits of an adaptive management approach in which management actions are treated as experiments, and results provide information to feed back into the management process. The Overton Bottoms North Unit of the Big Muddy National Fish and Wildlife Refuge is a part of the Missouri River Fish and Wildlife Habitat Mitigation Project. The dominant management action at the Overton Bottoms North Unit has been excavation of a side-channel chute to increase hydrologic connectivity and to enhance shallow, slow current-velocity habitat. The sidechannel chute also promises to increase hydrologic gradients, and may serve to alter patterns of wetland inundation and vegetation community growth in undesired ways. The U.S. Geological Survey's Central Region Integrated Studies Program (CRISP) undertook interdisciplinary research at the Overton Bottoms North Unit in 2003 to address key areas of scientific uncertainty that were highly relevant to ongoing adaptive management of the site, and to the design of similar rehabilitation projects on the Lower Missouri River. This volume presents chapters documenting the surficial geologic, topographic, surface-water, and ground-water framework of the Overton Bottoms North Unit. Retrospective analysis of vegetation community trends over the last 10 years is used to evaluate vegetation responses to reconnection of the Overton Bottoms North Unit to the river channel. Quasi-experimental analysis of cottonwood growth rate variation along hydrologic gradients is used to evaluate sensitivity of terrestrial vegetation to development of aquatic habitats. The integrated, landscapespecific understanding derived from these studies illustrates the value of scientific information in design and management of rehabilitation projects.

\section{Background and Introduction}

The channel form and flow regime of the Lower Missouri River have been substantially altered to promote economic development, but at the expense of fish and wildlife habitat (National Research Council, 2002). The Lower Missouri River (generally defined as the Missouri River downstream of Gavins Point Dam at Yankton, South Dakota, fig. 1) drains $1,300,000 \mathrm{~km}^{2}$ (square kilometers) at its mouth (U.S. Army Corps of Engineers, 1998). The river has been regulated since 1954 by the Missouri River Reservoir system, the nation's largest reservoir system with nearly $93 \mathrm{~km}^{3}$ (cubic kilometers) of storage. Engineering of the Lower Missouri River began in the 1830's with clearing, snagging, and bank stabilization to improve conditions for steamboat navigation. Most of the river's engineering structures date from the Missouri River Bank Stabilization and Navigation Project, first authorized in the Rivers and Harbors Act of 1912 and followed by an additional six acts of Congress in 1917, 1925, 1927, 1930, 1935, and 1945 (Ferrell, 1995). Wing dikes and revetments stabilized the riverbanks, and narrowed and focused the thalweg to maintain a self-dredging navigation channel from Sioux City, Iowa, $1,200 \mathrm{~km}$ downstream to St. Louis, Missouri. These engineering structures created a narrow, swift, and deep channel from what was historically a shallow, shifting, braided river, resulting in the loss of as much as $400 \mathrm{~km}^{2}$ of river-corridor habitats (Funk and Robinson, 1974; Hesse and Sheets, 1993; NRC, 2002; Galat and others, 2005).

Recognition of the scope of habitat loss has increased interest on rehabilitating parts of the Missouri River to help recover native biota (Latka and others, 1993). The U.S. Army Corps of Engineers (USACE) began implementing the Missouri River Fish and Wildlife Mitigation Project (Mitigation Project) in 1986. Initial authorization for mitigation along the Lower Missouri River was for 48,100 acres; an additional 118,650 acres were authorized in 1999 (USACE, 2004c). In 


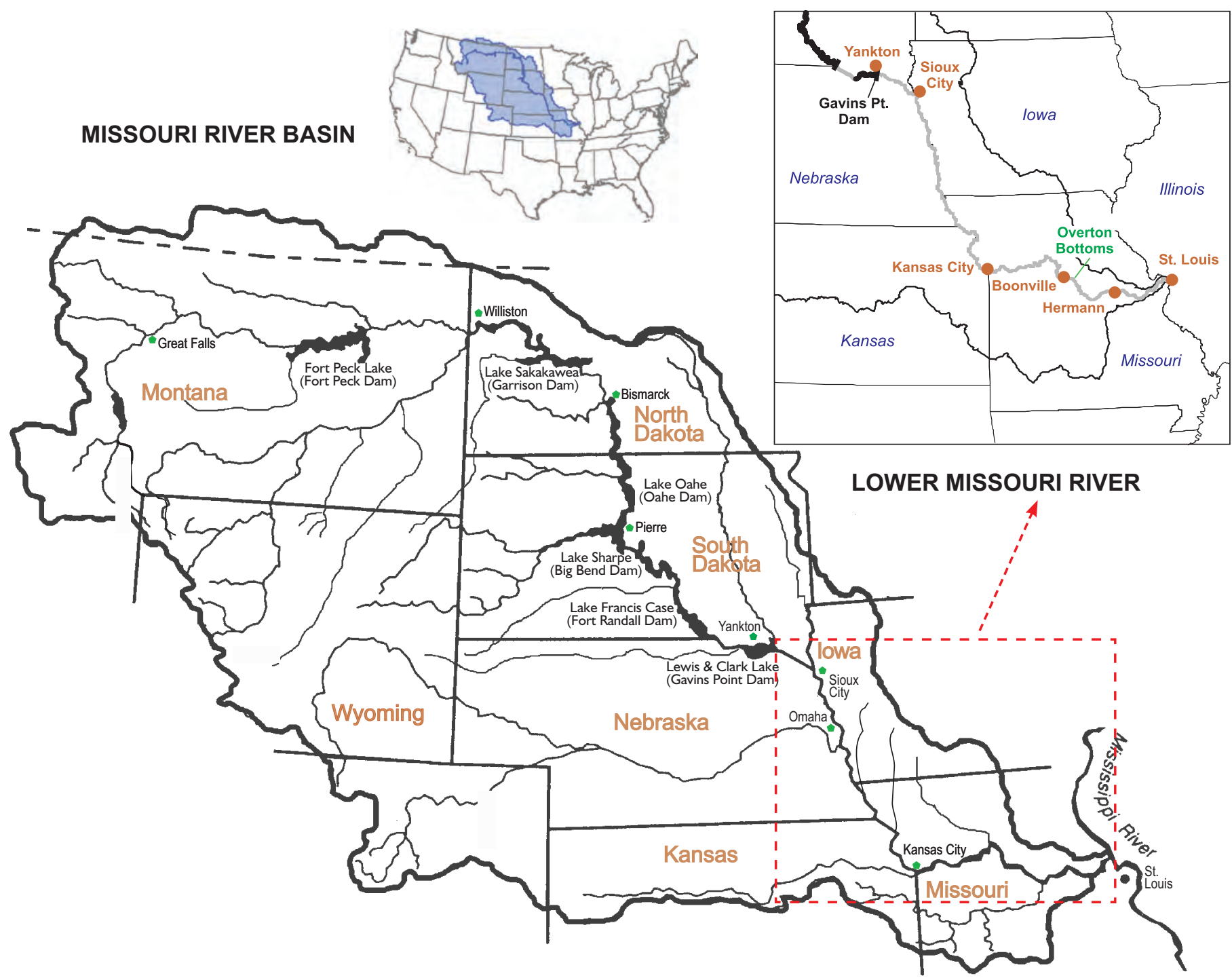

Figure 1. Lower Missouri River. The Lower Missouri River is defined as the 1,340 km of river from Yankton, South Dakota to St. Louis, Missouri. It starts downstream from the lower-most mainstem dam and ends at the confluence with the Mississippi River. The downstream 1,175 km is heavily engineered with wing dikes and revetments to form a stable, self-maintaining navigation channel from Sioux City, lowa to St. Louis.

1994, the U.S. Fish and Wildlife Service (USFWS) created the Big Muddy National Fish and Wildlife Refuge (Refuge) to acquire 60,000 acres of Missouri River bottomland between St. Louis and Kansas City, Missouri for habitat rehabilitation. Following the "Great Flood" of 1993, numerous landowners sold their flood-damaged lands to the USFWS, USACE, and other government agencies.

The Overton Bottoms North Unit of the Refuge (fig. 2) was originally acquired by the USACE as part of the Mitigation Project. Subsequently, the Refuge also purchased some adjacent land that was incorporated into the Overton Bottoms North Unit. Following the Mitigation Project model, the USACE-owned area was developed by the USACE and turned over to the USFWS for management.

Like many ecological restoration efforts, the Overton
Bottoms North Unit Rehabilitation Project involves considerable uncertainty (USACE, 1999; Wissmar and Bisson, 2003). Because levee breaks have opened the area to flow from the Missouri River, ecological responses are affected strongly by stochastic hydrologic events. Poorly predictable hydrologic events are further modulated by complex interactions between surface water and ground water. Ground-water hydraulics are also strongly controlled by poorly understood stratigraphy and sedimentology of surficial materials. Many have argued that management of natural resources in the context of uncertainty requires an adaptive management approach in which management actions are treated as experiments, and results are incorporated back into management strategies (Federal Interagency Stream Restoration Working Group, 1998; Downs and others, 2002; Palmer and others, 2005). 


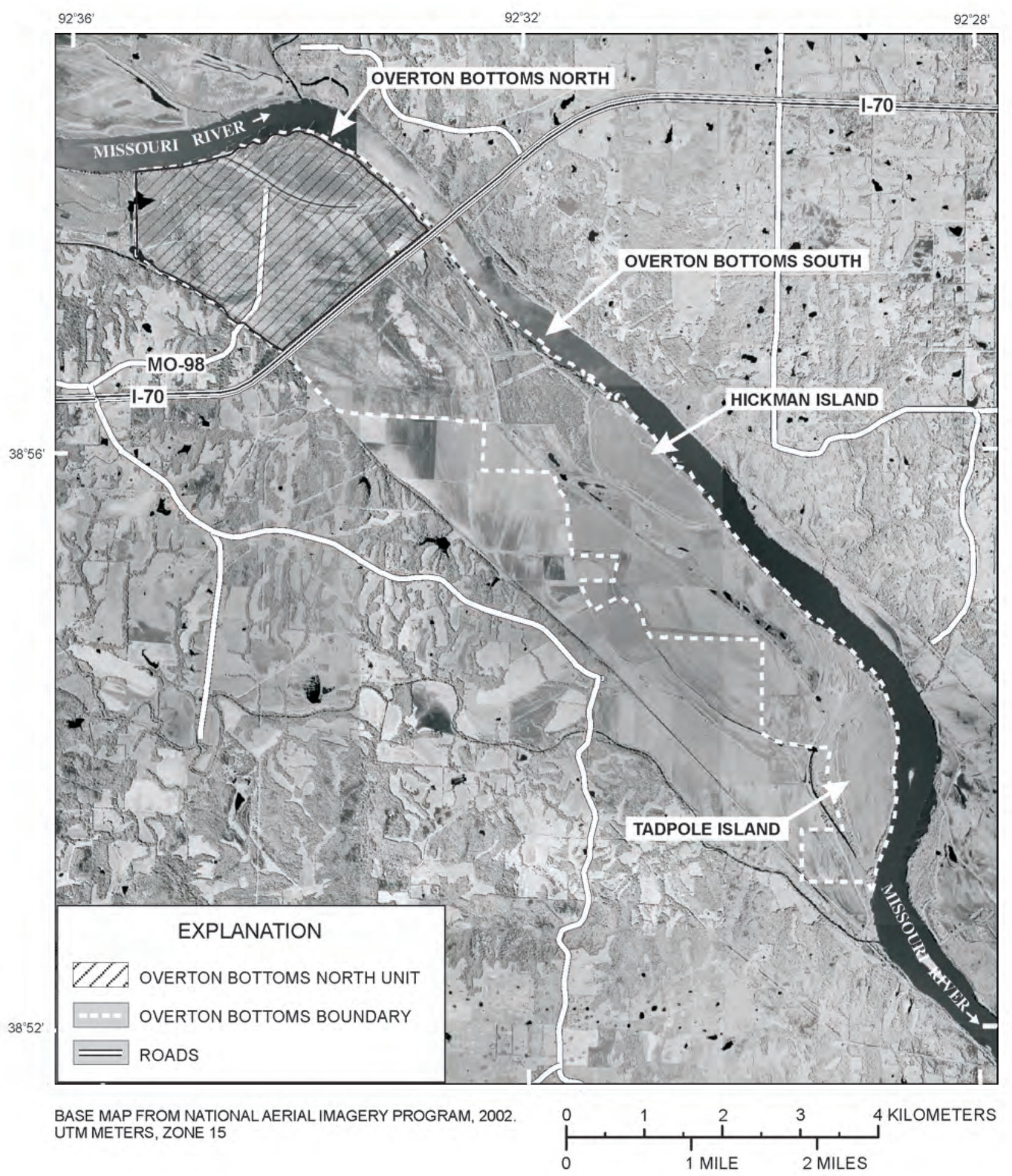

Figure 2. Location of the Overton Bottoms North Unit, Big Muddy National Fish and Wildlife Refuge, Missouri. The Overton Bottoms North and South Units are part of the U. S. Army Corps of Engineers Missouri River Fish and Wildlife Mitigation Project. The North Unit is managed by the U.S. Fish and Wildlife Service; the South Unit is managed by the Missouri Department of Conservation. 


\section{Purpose and Scope}

This report presents a case history of application of scientific investigations to adaptive management of a rehabilitation project along the Lower Missouri River. In the case of the Overton Bottoms North Unit, a key management question is how vegetation communities will respond to hydrologic alterations imposed by reconnection of the flood plain with the channel and side-channel chute construction. The trade-offs between aquatic habitat enhancement in the side-channel chute and potential degradation of flood-plain and wetland communities are of concern to Refuge managers (M. Gallagher, oral commun., 2002). The underlying scientific questions involve interaction of surface water and ground water, modulation of ground-water hydraulics by complex surficial geology, and the extent to which the target vegetation communities are sensitive to the altered hydrologic gradients. We chose vegetation as the biologic response variable because it is an element of habitat for many other biologic assemblages, it is directly manageable, and it is relatively easy to measure its distribution and processes.

This report is partitioned into six chapters that include:

1. This introduction.

2. Geologic and topographic context of the Overton Bottoms North Unit.

3. Ground water and surface water hydrology of the Overton Bottoms North Unit.

4. Broad-scale vegetation community responses to altered hydrology.

5. Fine-scale cottonwood growth-rate responses to altered hydrology.

6. Implications of scientific investigations for the adaptive management of the Overton Bottoms North Unit.

\section{Recent History of the Overton Bottoms North Unit}

Before the summer of 1993, the Overton Bottoms North Unit area was mostly farmland used for production of corn and soybeans. The peak daily mean flow during the 1993 flood was 20,400 cms (cubic meters per second) measured $16 \mathrm{~km}$ upstream at Boonville, Missouri. This discharge nearly matched the estimated 0.002 chance flood (that is, 500-year recurrence interval) for the Boonville gaging station (USACE, 2004a). The flood waters overtopped and breached levees at Overton Bottoms, flooded the valley from bluff to bluff, eroded a deep scour hole under the Interstate 70 bridge approach, and deposited extensive sand splays on the flood plain in the Overton Bottoms South area (fig. 2).
The 1993 flood was followed by six years of relatively high flows during which Overton Bottoms flooded multiple times (fig. 3). Six floods during this period were near or exceeded the estimated 0.2 chance flood (5-year recurrence interval) and 11 floods were near or exceeded the 0.5 chance flood (2-year recurrence interval). Long duration of the 1993 flood, recurring flooding, and un-repaired levees made the area nearly impossible to farm. During 1994-1997, the USACE and USFWS completed purchase of most of the Overton Bottoms North Unit, which eventually totaled 800 ha (hectares) (USACE, 1999).

The main habitat rehabilitation effort for the Overton Bottoms North Unit was construction of a flow-through sidechannel chute to provide aquatic habitat (USACE, 1999). Roads and parking lots were designed to afford access to the public. Management of the remaining 683 ha was originally intended to be low maintenance with managers relying on natural processes to recover flood-plain habitats to pre-agricultural conditions (USACE, 2002). However, some active planting of mast-bearing trees and invasive plant control efforts have been undertaken.

\section{Previous Scientific Investigations}

The 1993 flood also resulted in a new emphasis on ecological research on the Lower Missouri River. Numerous studies were undertaken to improve understanding of the role of flooding in sustaining populations and ecosystem processes (see for example, Galat and others, 1998). These studies illuminate the complex interactions between the water and land and the subsequent response of biota. Studies included:

- Integrative studies of flood-plain ecosystem processes including relations among hydrology, limnology, fish, shorebirds, and invertebrates (Chapman and others, 2004; Havel and others, 2000).

- Wetlands and waterfowl abundances (Ehrhardt, 1996; Humburg and others, 1996; McColpin, 2002).

- Vegetation community establishment and growth (Mazourek, 1998).

- Nutrient processing and limnology of the Missouri River and flood-plain wetlands (Knowlton and Jones, 1997, 2000, 2003; Blevins, 2004).

- Alluvial aquifer ground-water flow and relations between surface-water discharges and ground water (Kelly, 2000, 2001; Jacobson and Kelly, 2004a).

- Fish communities in scours and shallow-water habitats marginal to the main channel (Galat and others, 1997; Grady and others, 1999; Sargent and Galat, 2002). 


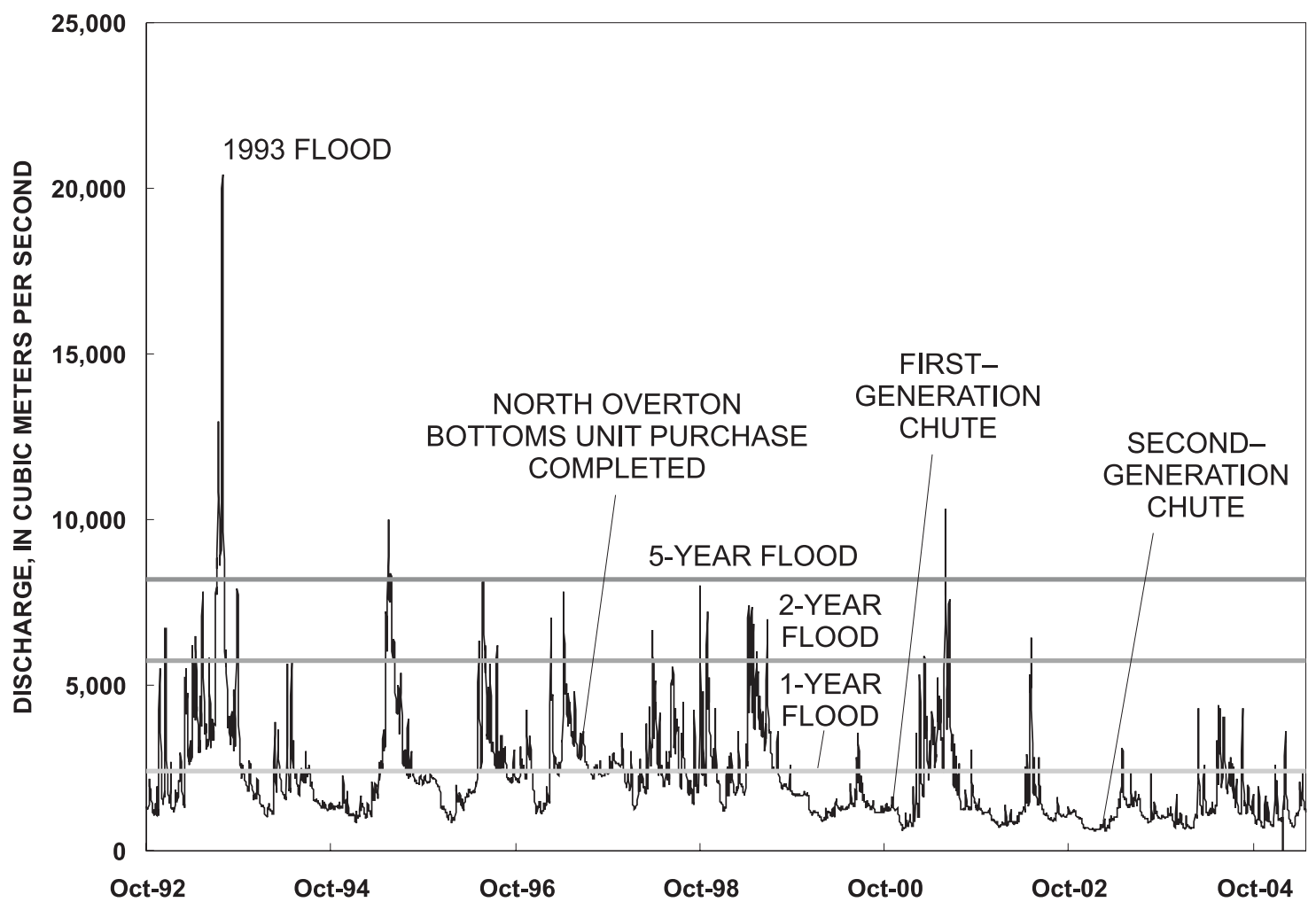

Figure 3. Missouri River at Boonville, Missouri, 1992-2005. Discharge recurrence intervals and events in the construction of the Overton Bottoms North Unit are noted. Recurrence intervals were calculated from the U.S. Army Corps of Engineers (2003).

- Life histories and habitat use of flood-plain dwelling turtles and mammals (Bodie and others, 2000; Bodie and Semlitsch, 2000a,b; Williams and others, 2001).

- Hydrology and geomorphology of the Lower Missouri River, including hydrology and geomorphic evolution of side-channel chutes (Jacobson and others, 1999; Galat and Lipkin, 2000; Jacobson and others, 2001; Jacobson and Heuser, 2002; Jacobson and others, 2004a, b).

\section{Resource Management Issues}

Rehabilitation strategies on the Missouri River fall into several distinct categories, covering a range of passive to intensive approaches (table 1).

The intent of all these rehabilitation strategies is to naturalize the river corridor (see Rhoads and others, 1999) by increasing the diversity and dynamic range of habitats. However, the scientific basis for design of such projects is poor. Most designs are based on the premise that any change that increases topographic and hydrologic variability will be an improvement. This approach assumes that once the new physical system is in place, there will be desirable biological results. Experience in monitoring physical aspects of several existing rehabilitation projects has demonstrated that stochastic hydrology and poorly understood sediment and woody-debris transport systems combine to produce substantial uncertainty in how the physical template will evolve (Jacobson and others, 2001; 2004b; Chapman and others, 2004). Moreover, general understanding of the inherent complexity of riverine ecosystems indicates that biotic responses are likely to be complex and unpredictable (Hilderbrand and others, 2005; Wissmar and Bisson, 2003).

The large uncertainties associated with performance of rehabilitation projects dictates an adaptive management approach in which performance monitoring and analysis are used to adjust project design, enhance maintenance, and/or realign project objectives (Downs and others, 2002). Within the adaptive management framework, rehabilitation projects become large-scale field experiments that have great potential for exploration of complex ecosystem responses to imposed manipulations (NRC, 1999, 2002; Allen and others, 2001). 
Table 1. Types of rehabilitation activities in the Lower Missouri River corridor

\begin{tabular}{lcc}
\hline \multicolumn{1}{c}{ Type } & Objectives & Approach \\
\hline $\begin{array}{l}\text { Intensively managed } \\
\text { wetlands }\end{array}$ & $\begin{array}{c}\text { Provide specific wetland habitats and associated } \\
\text { food sources at specific times of the year to } \\
\text { support, mostly, waterfowl production. }\end{array}$ & $\begin{array}{c}\text { Construct leveed wetland compartments; } \\
\text { manipulate interior drainage; pump or drain } \\
\text { as needed to optimize water levels; plant food } \\
\text { crops for water fowl }\end{array}$ \\
$\begin{array}{l}\text { Passive wetlands } \\
\text { Side-channel chutes }\end{array}$ & $\begin{array}{l}\text { Provide general wetland habitats at least cost. } \\
\text { Provide off-channel aquatic habitats; increase } \\
\text { hydrologic connection of valley bottom to } \\
\text { main channel. }\end{array}$ & $\begin{array}{c}\text { Remove levees to increase frequency of flooding } \\
\text { Construct off-channel chute; inlets and outlets } \\
\text { variably designed to achieve hydroperiod and } \\
\text { sediment transport objectives }\end{array}$ \\
$\begin{array}{c}\text { Shallow-water within } \\
\text { channel }\end{array}$ & $\begin{array}{c}\text { Provide shallow, slow current-velocity habitat } \\
\text { along margins of main channel. }\end{array}$ & $\begin{array}{c}\text { allow lateral erosion; manipulate wing dikes to } \\
\text { achieve diversity of habitat. }\end{array}$ \\
\hline
\end{tabular}

\section{Overton Bottoms North Unit Case Study}

Habitat rehabilitation at the Overton Bottoms North Unit provided an opportunity to use management actions as adaptive management experiments. The two major management activities at the Overton Bottoms North Unit were construction of the side-channel chute and relatively passive management of vegetation communities in the remaining area.

The long-term geomorphic evolution of the side-channel chute, the types of habitats it produces, and effects on adjacent flood-plain areas and the main channel of the Missouri River are primary management concerns at Overton Bottoms North (USACE, 1999). Jacobson and others (2004b) described hydrologic characteristics, hydraulics, habitats, and geomorphic evolution of four side-channel chutes on the Lower Missouri River, including the Overton Bottoms North Unit side-channel chute; the following description is from that report. The initial construction of the chute was in 2000 (fig. 4). Because of a very conservative design, the first generation of the side-channel chute was remarkably stable despite being designed as a pilot side-channel chute and being subjected to multiple floods with a 2-5 year recurrence intervals (fig. 3). After three years of existence, the Overton Bottoms North Unit side-channel chute had produced little natural aquatic habitat and was in danger of filling in with sediment in the downstream half. To correct this situation the side-channel chute was re-aligned and re-excavated during spring 2003. Excavation deepened, steepened, and enlarged the chute (figs. 4, 5). Placement of excavation spoil at the top of vertical banks was intended to promote bank instability and accelerate geomorphic adjustment. Compared to the first-generation design, re-engineering of the side-channel chute in 2003 reflected a much less risk-averse attempt to promoting dynamic habitats. The extreme change in side-channel chute form produced the opportunity to investigate the effect of hydrologic gradients on ecological processes as pursued in this report. Ongoing U.S. Geological Survey investigations are documenting geomorphic adjustment of the side-channel chute.

Vegetation community changes also are of particular interest to Refuge managers at the Overton Bottoms North Unit as they comprise fundamental habitat attributes for many other biotic components (Thomas Bell, oral commun., 2000). One frequently cited management goal for riverine areas is enhancement of hard mast-producing trees such as oaks and hickories to provide food sources for deer and turkeys (Grossman and others, 2003). An alternative management goal could be to restore the presettlement vegetation of the valley bottom. The early successional stages of cottonwood/willow communities that dominate much of the valley-bottom conservation lands affected by the 1993 flood were also dominant in pre-settlement time (Harlan and Denny, 2003) and have been shown to be important habitat for other bird species, including neotropical migrants (Swanson, 1999). The successional trajectory of flood-plain communities is therefore an important question for managers: should the communities be actively managed with planting, burning, or thinning, or can management values be achieved through low-maintenance, passive approaches?

A related vegetation issue is how to manage or control invasive species. Johnson grass (Sorghum halepense), for example, is an aggressive non-native species that grows prolifically in open areas of the Overton Bottoms North Unit 


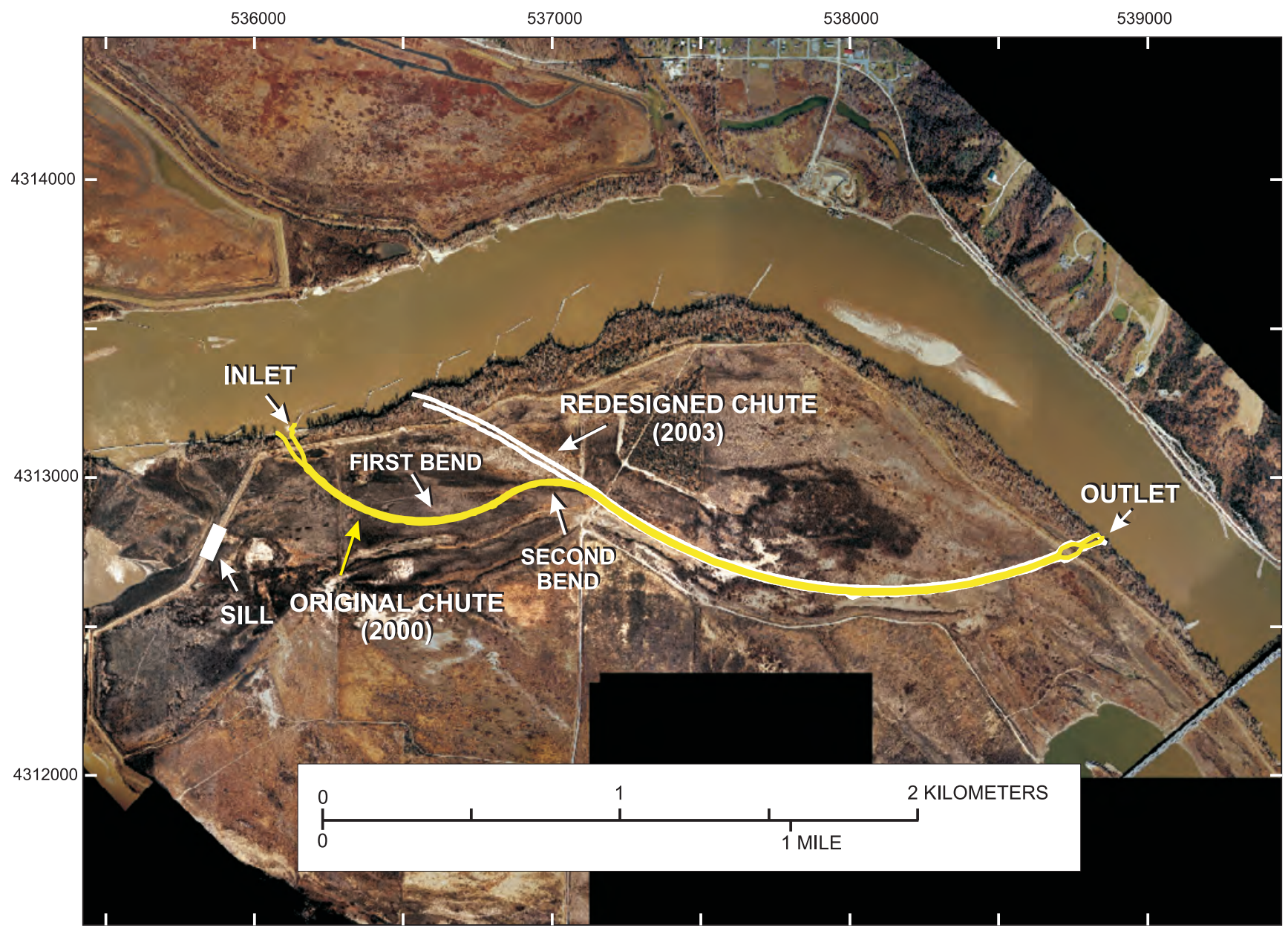

DIGITAL BASE MAP DATA, UTM METERS, ZONE 15

AERIAL PHOTOGRAPH, U.S. ARMY CORPS OF ENGINEERS, 2000, UNPUBLISHED DIGITAL DATA.

Figure 4. Locations of the side-channel chutes and features at Overton Bottoms North.

(Barbara Moran, oral commun., 2000). Managers would like to know whether Johnson grass invasion is a transient phenomenon that will eventually succumb to shading from tree communities, or whether Johnson grass will require a long-term management strategy. Understanding of the surficial geology and hydrology of the Overton Bottoms North Unit landscape may also demonstrate spatial controls on distributions of invasive species and therefore indicate ways to maximize management efforts.

In addition to terrestrial habitat management questions, there is considerable interest in aquatic habitats, especially as they promote recovery of threatened and endangered species. In 2003, the USACE began creating shallow, slow current-velocity habitat (SWH) intended to provide nursery and rearing habitat for young native fishes, and in particular to benefit the endangered pallid sturgeon (Scaphirhynchus albus) (USFWS, 2003; USACE, 2004b). SWH is defined as water 0 to 5 feet deep $(0-1.5 \mathrm{~m}$ [meter]) and 0 to 2 feet per second $(0-0.75 \mathrm{~m} / \mathrm{s}$ [meter per second]) current velocity. The side-channel chute at the Overton Bottoms North Unit and additional areas adjacent to the Refuge on the margins of the main channel (fig. 2) have been considered part of the SWH enhancement effort. Development of aquatic habitat, however, necessarily involves a trade-off: the loss of some flood-plain or wetland habitat. For example, development of SWH in the main channel adjacent to the Refuge in 2004 resulted in the loss of approximately 8 ha (hectares) of woody riparian corridor. Mature cottonwood trees in the area may have provided roosting and nesting sites for bald eagles and other birds. A central question addressed by this volume is the extent to which development of the side-channel chute affects wetland hydrology, and consequently, flood-plain vegetation community patterns, growth rates, and associated habitats for other species. 


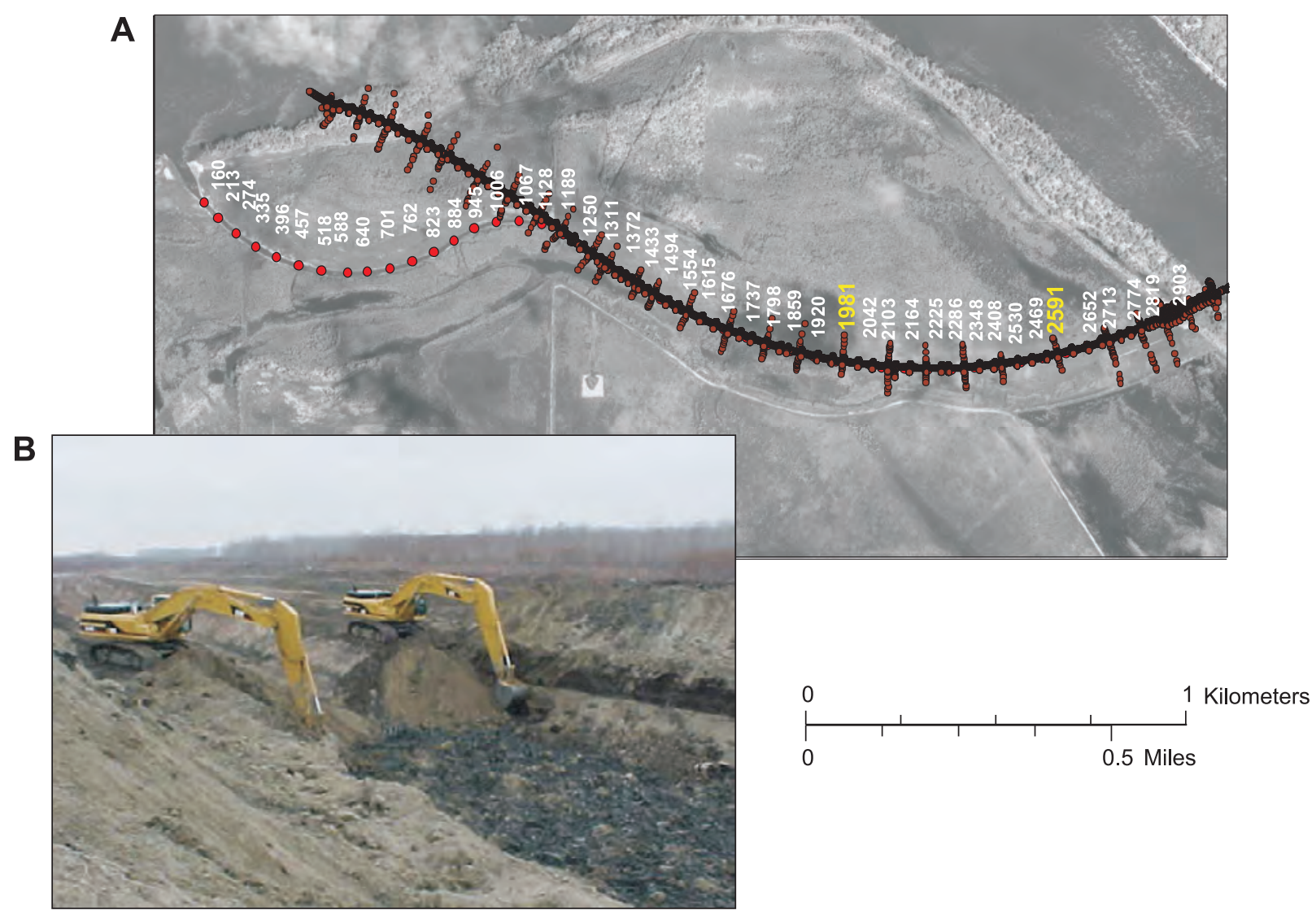

C
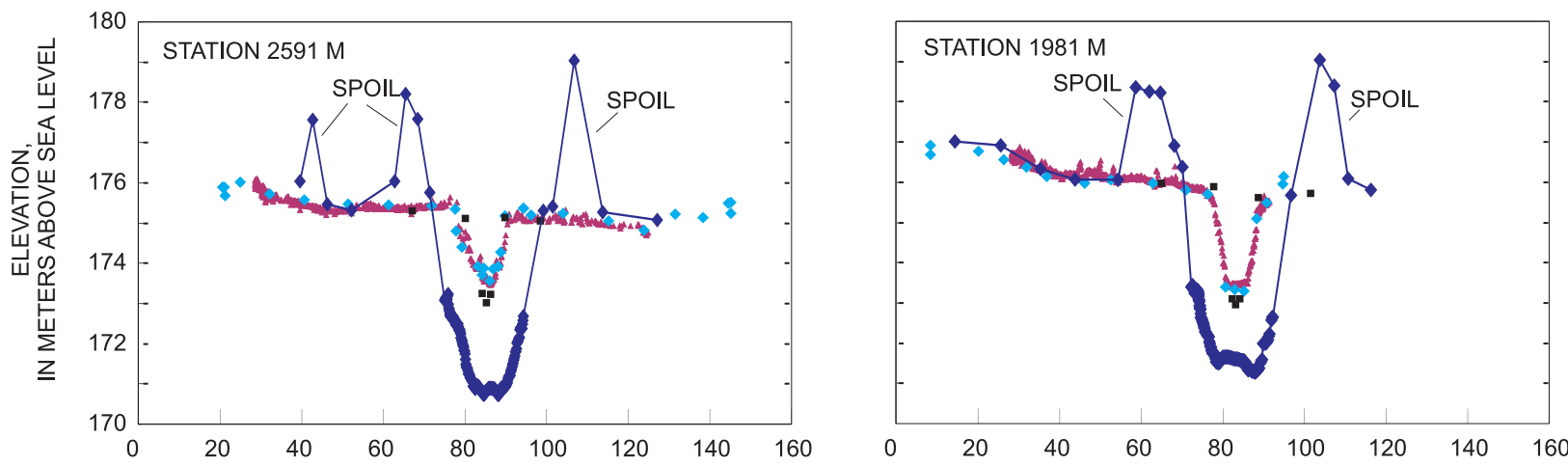

DISTANCE ALONG TRANSECT, METERS

\section{EXPLANATION}

As-Built Original Survey October 2000

USGS Total Station Survey October 23, 2001
- USGS Hydroacoustic Survey May 15, 2002

USGS Re-Designed Survey, Hydroacoustics \& Total Station May 13, 2003

Figure 5. Adaptive re-excavation of Overton Bottoms North chute. A. Map of first-generation and second-generation chutes showing cross-section monitoring locations. B. Excavation of chute in spring 2003. C. Representative cross sections showing first generation of chute and the extent of deepening, steepening, and enlargement by re-excavation. 


\section{Science Questions}

Although a great deal is understood in general about the value of connections between rivers and their flood plains (Junk and others, 1989; Bayley, 1995; Sparks and others, 1998), scientific understanding is insufficient to provide specific guidance for rehabilitation design and to evaluate resource trade-offs. This volume addresses some of the fundamental science questions underlying rehabilitation design in context of a specific landscape.

\section{Surficial Geologic Framework}

Surficial geology refers to the study of the rocks and mainly unconsolidated materials that lie at or near the land surface (Ruhe, 1975). Surficial geology encompasses the topography of the land surface and the stratigraphy, sedimentology, geochronology, and pedology of the underlying sediments (Jacobson and others, 2003). Only recently have substantive efforts been applied to describing and mapping the surficial geology of the Lower Missouri Valley (see publications cited in this volume, chapter 2).

Understanding of the surficial geologic record has two fundamental applications to adaptive management of bottomland resources. The sediments that comprise the alluvial valley fill, their properties and stratigraphic sequence, and their characteristic surface morphologies are strong controls on ground- and surface-water distributions. Surficial geologic maps and sub-surface data, therefore, are rich in information with a direct bearing on habitat capability of the landscape. In addition, the historical information that can be interpreted from understanding of surficial geology presents a unique perspective on long-term landscape behavior. The geologic record of how river deposition and erosion have responded to hydroclimatic and anthropogenic events can be important in understanding the range of disturbances a river is subject to under present-day conditions (Jacobson and others, 2003).

Scientific questions being addressed through surficial geologic investigations include:

- What are the effects of late Pleistocene and Holocene climatic events on hydrology, sediment supply, sediment transport, erosion, and deposition of the Lower Missouri River?

- What are the valley-scale controls on preservation, stratigraphy, and sedimentology of the alluvial valley fill?

- How do hydraulic properties, stratigraphy, and surface morphology correlate among mappable allostratigraphic units?
While the direct role of surficial geologic studies at the Overton Bottoms North Unit are in application to groundwater hydraulics and wetland distributions, the surface and subsurface data collected at Overton Bottoms North Unit for this project adds to a growing body of information on surficial geology of the Lower Missouri River.

\section{Hydrology}

Breaching of levees and construction of the side-channel chute at the Overton Bottoms North Unit increased the opportunity for hydrologic connection between the channel and the rest of the river corridor. Connectivity was increased for floods ranging from bankfull to those that would have overtopped the pre-existing levees with 1.5 to 10 year recurrence intervals. Flooding pathways provided by levee breaches and the chute, however, also may speed drainage from the flood plain after a flood, thereby decreasing length of inundation. In addition, the side-channel chute may allow for greater infiltration or drainage from the alluvial aquifer than would have existed without it. Because of complex interactions between surface and ground water, the net affect of rehabilitation activities involves considerable scientific uncertainty.

Science questions related to hydrology include:

- How do inundated area, residence times, depths, and current velocities vary with discharge?

- How are spatial patterns of inundation controlled by topography?

- How sensitive are surface-water flow patterns to hydraulic roughness induced by vegetation communities, and how do roughness effects change as communities undergo successional change?

- How do surface water and ground water interact to influence near-surface moisture distributions and water quality?

- To what extent do surficial geologic strata control permeabilities, transmissivities, and ground-water levels?

- How do topographic alterations associated with rehabilitation activities affect the overall hydrologic response of river bottoms?

The Overton Bottoms North Unit provides a field setting for exploration of these hydrologic questions and for evaluating how surface- and ground-water interactions may change over the long term as geomorphic and vegetation adjustments proceed. Although this report does not address all these questions exhaustively, it provides the framework for quantifying hydrologic alteration at the Overton Bottoms North Unit. 


\section{Selected Ecological Responses}

Biotic changes associated with hydrologic alteration of the Overton Bottoms North Unit have the potential to be widespread as hydrology is a fundamental driver of rivercorridor ecosystem processes. Responses may be direct responses to how much, how long, and how frequently a site is inundated, or responses may be complex and indirect in relation to vegetation and/or water-quality alterations. Moreover, biotic responses may be measurable at many different trophic levels, from primary productivity to population characteristics of vertebrate species.

Evaluations of ecological restoration projects must often confront which biotic indicators are most effective for performance assessment (Palmer and others, 2005). In some cases, performance may be best assessed in terms of physical/chemical parameters like residence time of water, carbon retention, or nitrogen processing. In many cases, however, there is a need to demonstrate performance in terms of biotic responses. Although vegetation communities are not a universal indicator of ecosystem performance, they are effective indicators because of the relative ease of sampling vegetation in the field and through remote sensing, and because vegetation often contributes substantially to habitat quality for other biota.

Dominant scientific questions related to vegetation communities are:

- What are the successional trajectories and time frame for flood-plain vegetation communities?

- Are trajectories toward steady state vegetation communities (measured in terms of species composition) different depending on the antecedent land cover?

- Are vegetation communities different depending on topographic and surficial geologic characteristics of the valley bottom?

- Are typical flood-plain vegetation communities sensitive to the scale of hydrologic alteration in floodplain rehabilitation projects?

Because substantial areas at the Overton Bottoms North Unit have entirely new vegetation communities since the 1993 flood, the area serves as a long-term experiment for evaluating successional trajectories. In addition, active manipulation of the side-channel chute provides opportunities for experimental evaluation of sensitivity of tree communities to steepened hydrologic gradients.

\section{The Role of Science in Adaptive Resource Management}

The concept of adaptive management has been promoted as a way to deal with uncertainties in natural resource management. In its simplest form, adaptive management is a structured process of "learning by doing" (Walters, 1986, 1997), but it is also used to describe more formal processes of systems modeling and iterative hypothesis testing (Blumenthal and Jannink, 2000). Adaptive management is usually described as a formal, multi-step process (Walters, 1986):

1. Identification of management problems.

2. Setting of management objectives through the lens of the ecosystem/basin stakeholder vision and goals.

3. Integration of existing information on how the system operates into dynamic models to predict how alternative management decisions will alter the system.

4. Testing and selection of management experiments through the aforementioned models.

5. Design of actual field experiments.

6. Implementation of management experiments.

7. Monitoring and evaluation of experiments and their affects on system performance.

8. Feedback to update models, reassessment, update of management actions.

9. Repeat as necessary to achieve objectives, goals and vision.

The rehabilitation project at Overton Bottoms North Unit did not follow this formal process. In particular, the design of management experiments around scientific models, steps $3-5$, was omitted. Step 7 (including work described in this report and several other projects) was pursued opportunistically rather than being an integral part of the rehabilitation project. The assessment and modeling aspects of step 8 have not occurred. Re-excavation of the side-channel chute in 2003 could be interpreted as adaptive management, but it did not occur within the context of systematic evaluation of ecological performance of the system. Finally, whether adaptive management is institutionalized (step 9) in the future remains to be seen. Nevertheless, the Overton Bottoms North Unit Rehabilitation Project fulfills the fundamental descriptor of adaptive management as "learning by doing".

In retrospect, two simple conceptual models define the Overton Bottoms North Unit Rehabilitation Project experiment. The first conceptual model (or hypothesis) is that allowing hydrologic connection to the Overton Bottoms North Unit will create patches of vegetation communities that will evolve along successional trajectories defined by their position on the landscape and the underlying surficial geologic materials. Over a multi-decade time frame, these patches will provide spatially varied and dynamic habitats. The data and analyses presented in chapters $2-4$ of this volume develop this model in greater detail.

The second conceptual model involves the detailed interaction between surface water and ground water adjacent 
to the side-channel chute. The model (or hypothesis) states that steep hydrologic gradients induced by the side-channel chute will affect hydroperiod in adjacent wetlands and growth rates of native tree species (fig. 6). Whether this conceptual model is valid or not depends, at least, on permeability of the alluvial materials and the sensitivity of tree species to the new hydrologic gradients. This model is explored in this volume, chapter 5 .

Realistically, the rehabilitation project at the Overton Bottoms North Unit cannot be considered a formal experiment as it does not involve complete randomization of treatments and sampling; rather, the evaluation is a quasi-experiment similar to conventional before-after/control-impact designs (Block and others, 2001). Although quasi-experiments do not have the inferential power of completely randomized experiments, they are much more practical in typical field situations. In the case of the Overton Bottoms North Unit Rehabilitation Project, we consider retrospective analysis tracking vegetation community growth over time and evaluation of growth rates related to hydrologic gradients as exploratory quasi-experiments that can yield useful knowledge about process and broad constraints on possible effects. As such, they are especially useful in developing detailed hypotheses relevant to the existing landscape for subsequent testing under more rigorous conditions. While these experiments have not been designed to have the inferential power to reject hypotheses with any degree of statistical significance, they are intended to provide useful knowledge for management decisions.

\section{Conclusion}

The overall objective of the chapters in this volume is to provide scientific information that will be useful in adaptive management of Lower Missouri River rehabilitation projects. Adaptive management recognizes the important role of science in iteratively refining understanding and decreasing management uncertainties (for example, NRC, 2003). Science is most effective in resource management when it is demonstrably relevant, comes from authoritative sources, and comes from trusted institutions. These are the characteristics of salience, credibility, and legitimacy recognized in sustainable development theory (Cash and others, 2003).

Adaptive management projects also provide important opportunities for scientists to explore new ideas at landscape scales, to demonstrate the relevance of those ideas to management issues, and to communicate ideas to a broad audience. Under the best adaptive management scenario, substantial benefits will accrue to both scientists and managers. Hopefully, this report will achieve the goals of saliency, credibility, and legitimacy of science, and as such, it will contribute to the continued involvement of science in adaptive management of rehabilitation projects on the Lower Missouri River.

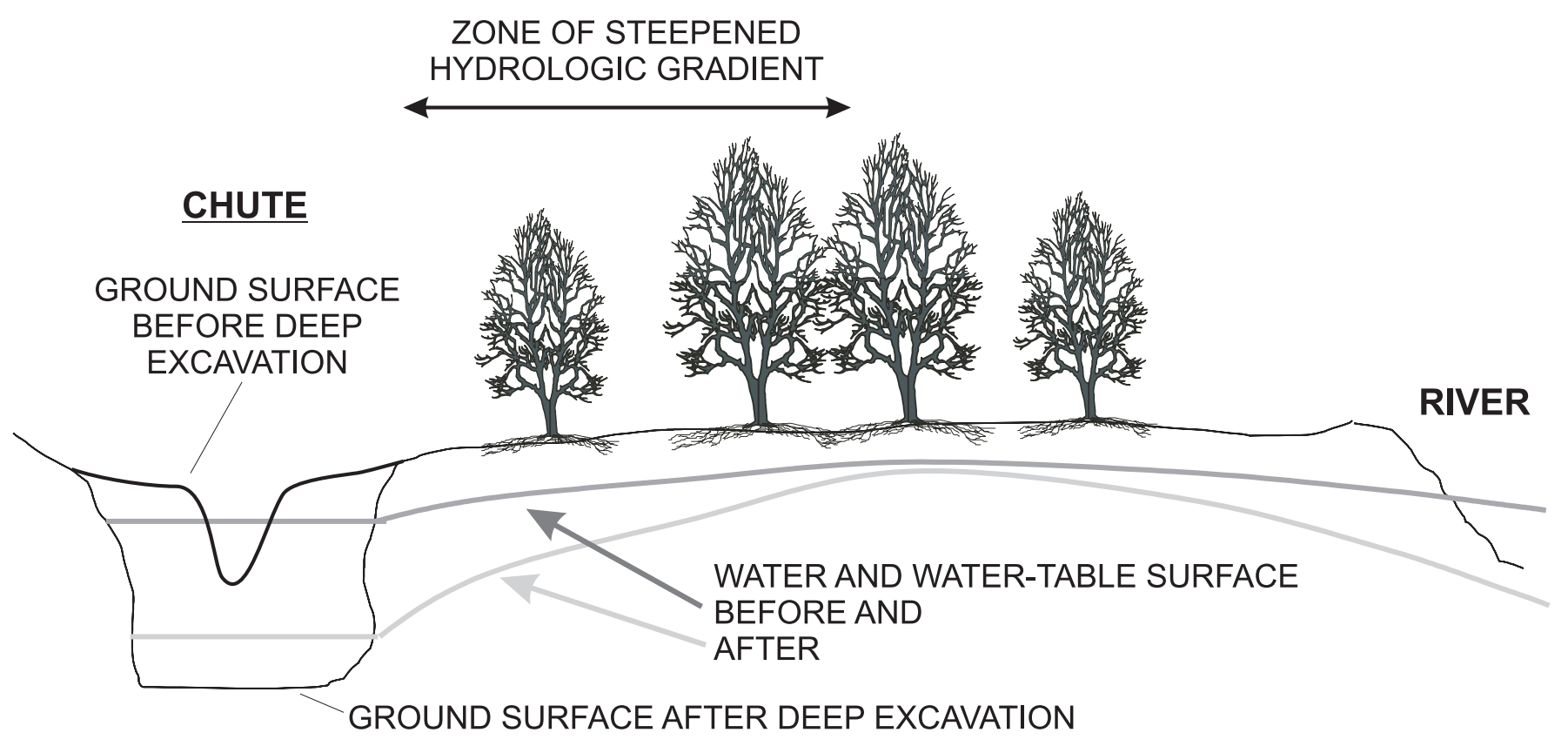

Figure 6. Conceptual model of how water levels, hydrologic gradients, and tree-growth rates might be expected to vary with deepening of the chute at Overton Bottoms North. 


\section{References Cited}

Allen, E.B., Covington, W.W., and Falk, D.A., 2001, Developing the conceptual basis for restoration ecology: Restoration Ecology, v. 5, p. 275-276.

Bayley, P.B., 1995, Understanding large river-floodplain ecosystems: BioScience v. 45, p. 153-158.

Blevins, D.W., 2004, Hydrology and cycling of nitrogen and phosphorus in Little Bean Marsh-a remnant riparian wetland along the Missouri River in Platte County, Missouri, 1996-97: U.S. Geological Survey Scientific Investigations Report, 2004-5171, 78 p.

Block, W.M., Franklin, A.B., Ward, J.P. Jr., Ganey, J.L., and White, G.C., 2001, Design and implementation of monitoring studies to evaluate the success of ecological restoration on wildlife: Restoration Ecology, v. 9, p. 293-303.

Blumenthal, D., and Jannink, J.L., 2000, A classification of collaborative management methods: Conservation Ecology, v. 4, 21 p., accessed February, 2006, at URL http://www. consecol.org/vol4/iss2/art13.

Bodie, J.R., Semlitsch, R.D., and Renken, R.B., 2000, Diversity and structure of turtle assemblages-associations with wetland characters across a floodplain landscape: Ecography, v. 23, p. 444-456.

Bodie, J.R., and Semlitsch, R.D., 2000a, Spatial and temporal use of floodplain habitats by lentic and lotic species of aquatic turtles: Oecologia, v. 122, p. 138-146.

Bodie, J.R., and Semlitsch, R.D., 2000b, Size-specific mortality and natural selection in freshwater turtles: Copeia, v. 2000 , p. $732-739$.

Cash, D.W., Clark, W.C., Alcock, F., Dickson, N.M., Eckley, N., Guston, D.H., Jager, J., and Mitchell, R.B., 2003, Knowledge systems for sustainable development: Proceedings of the National Academy of Sciences, v. 100, 7 p.

Chapman, D.C., Ehrhardt, E.A., Fairchild, J.F., Jacobson, R. B., Kelly, B.P., Mabee, W.R., Poulton, B.C., and Sappington, L.C., 2004, Ecological dynamics of wetlands at Lisbon Bottom, Big Muddy National Fish and Wildlife Refuge, Missouri: U.S. Geological Survey Open-File Report 20041036, 160 p., accessed February, 2006, at URL http://www. cerc.usgs.gov/pubs/MoRiver/OFR_2004-1036.htm.

Downs, P.W., Kondolf, G.M., Keough, M.J., Lake, P.S., Mapstone, B.D., and Quinn, G.P., 2002, Post-project appraisals in adaptive management of river channel restoration: Environmental Management, v. 29, p. 477-496.

Ehrhardt, E., 1996, Abundance and distribution of waterbirds of three habitats of Missouri River floodplain following a major flood: Columbia, Mo., University of Missouri, Master's thesis, $111 \mathrm{pp}$.
Federal Interagency Stream Restoration Working Group, 1998, Stream corridor restoration-principles, processes, practices: Washington, D.C., USDA, Natural Reseources Conservation Service, variously paginated.

Ferrell, J., 1995, Soundings-100 years of the Missouri River navigation project: U.S. Army Corps of Engineers, U.S. Government Printing Office, 1996-555-110, 171 p.

Funk, J.L., and Robinson, J.W., 1974. Changes in the channel of the Lower Missouri River and effects on fish and wildlife: Jefferson City, Mo., Missouri Department of Conservation, $52 \mathrm{p}$.

Galat, D.L., Kubisiak, J.F., Hooker, J.B., and Sowa, L.M., 1997, Geomorphology, distribution, and connectivity of Lower Missouri River floodplain waterbodies scoured by the flood of 1993: Verh. Internat. Verein. Limnolo., v. 26, p. 869-878.

Galat, D.L., Fredrickson, L.H., Humburg, D.D., Bataille, K.J., Bodie, J.R., Dohrenwend, J., Gelwicks, G.T., Havel, J.E., Helmers, D.L., Hooker, J.B., Jones, J.R., Knowlton, M.F., Kubisiak, J., Mazourek, J., McColpin, A.C., Renken, R.B., and Semlitsch, R.D., 1998, Flooding to restore connectivity of regulated, large-river wetlands: Bioscience, v. 48, p. 721-733.

Galat, D. L., and Lipkin, R., 2000, Restoring the ecological integrity of great rivers-historical hydrographs aid in defining reference conditions for the Missouri River: Hydrobiologia, v. 422/423, p. 29-48.

Galat, D.L., Berry, C.R., Peters, E.J., and White, R.G., 2005, Missouri River basin, in, Benke, A., and Cushing, C., eds., Rivers of North America: New York, Elsevier Academic Press, p. 427-480.

Grady, J., Milligan, J., Chapman, D., Ehrhardt, E., Dieterman, D., Galat, D., Hooker, J., Kubisiak, J., Delonay, A., Little, E., Robinson, J., and Tibbs, J., 1999, Fishes of Missouri River, chute, and flood-plain habitats, Chapter 4 of Humburg, D.D., and Burke, V.J., eds., Initial Biotic Survey of Lisbon Bottom, Big Muddy National Fish and Wildlife Refuge: U.S. Geological Survey, Biological Resources Division Biological Science Report, USGS/BRD/BSR-2000-0001, $76 \mathrm{p}$.

Grossman, B.C., Gold, M.A., Dey, D.C., 2003, Restoration of hard mast species for wildlife in Missouri using precocious flowering oak in the Missouri River floodplain: USA Agroforestry Systems, v. 2003, p. 3-10.

Harlan, J.D., and Denny, J.M., 2003, Atlas of Lewis and Clark in Missouri: Columbia, Mo., University of Missouri Press, 152 p., accessed February, 2006, at URL http://lewisclark. geog.missouri.edu/website/moriver1/viewer.htm. 
Havel, J.E., Eisenbacher, E.M., and Black, A.A., 2000, Diversity of crustacean zooplankton in riparian wetlands-colonization and egg banks: Aquatic Ecology, v. 34, p. 63-76.

Hesse, L.W., and Sheets, W., 1993, The Missouri River hydrosystem: Fisheries, v. 18, p. 5-14.

Hilderbrand, R.H., Watts, A.C., and Randle, A. M., 2005, The myths of restoration ecology: Ecology and Society, v. 10, 11 p., accessed February, 2006, at URL http://www. ecologyandsociety.org/vol10/iss1/art19.

Humburg, D.D., Graber, D.A., Havera, S.P., Fredrickson, L., and Helmers, D.L., 1996, What did we learn from the great flood of 1993, in Ratti, J.T., ed., Proceedings of the 7th international waterfowl symposium: Memphis, Tenn., p. $139-148$.

Jacobson, R.B., Laustrup, M.S., Ehrhardt, E., Niebur, C, Arvidson, R., 1999, Physical setting of Lisbon Bottom in the Big Muddy National Fish and Wildlife Refuge, Chapter 1 of Humburg, D.D., and Burke, V.J., eds., Initial biotic survey of Lisbon Bottoms, Big Muddy National Fish and Wildlife Refuge: U.S. Geological Survey Biological Sciences Report USGS/BRD/BSR-2000-0001, p. 1-20, accessed February, 2006, at URL http://www.cerc.usgs.gov/pubs/center/pdfDocs/Lisbon.pdf.

Jacobson, R.B., and Heuser, J.L., 2002, Visualization of flow alternatives, Lower Missouri River: U.S. Geological Survey Open-File Report 02-122, unpaginated, accessed February, 2006, at URL http://www.cerc.usgs.gov/rss/visualize/visualize.htm.

Jacobson, R.B., Laustrup, M.L., and Chapman, M.D., 2001, Fluvial processes and passive rehabilitation of the Lisbon Bottom side-channel chute, Lower Missouri River, in, Dorava, J.M., Montgomery, D.L., Fitzpatrick, F.A., and Palcsak, B.B., eds., Fluvial processes and physical habitat: American Geophysical Union Water Science and Application Series, v. 4, p. 199-216.

Jacobson, R.B., O'Connor, J.E., and Oguchi, T., 2003, Surficial geologic tools in fluvial geomorphology, in Kondolf, G.M. and Piegay, H., eds., Tools in Fluvial Geomorphology: New York, Wiley Interscience, p. 25-57.

Jacobson, R.B. and Kelly, B.P., 2004a, Hydrology, in, Chapman, D.C., Ehrhardt, E.A., Fairchild, J.F., Jacobson, R.B., Kelly, B.P., Mabee, W.R., Poulton, B.C., and Sappington, L.C., Ecological dynamics of wetlands at Lisbon Bottom, Big Muddy National Fish and Wildlife Refuge, Missouri: U.S. Geological Survey Open-File Report 2004-1036, p. 13-36, accessed February, 2006, at URL http://www.cerc. usgs.gov/pubs/MoRiver/OFR_2004-1036.htm.

Jacobson, R.B., Johnson, H.E., Laustrup, M.S., D’Urso, G.J., and Reuter, J.M., 2004b, Physical habitat dynamics in four side-channel chutes, Lower Missouri River: U.S. Geological
Survey Open-File Report 2004-1071, 60 p., accessed February, 2006, at URL http://www.cerc.usgs.gov/pubs/MoRiver/ OFR_2004-1071.htm.

Junk, W.J., Bayley, P.B., and Sparks, R.E., 1989, The flood pulse concept in river-floodplain systems: Canadian Special Publication Fisheries and Aquatic Sciences, v. 106, p. 110-127.

Kelly, B.P., 2000, Effects of alternative Missouri River management plans on ground-water levels in the Lower Missouri River flood plain: U.S. Geological Survey WaterResources Investigations Report 2000-4052, 128 p.

Kelly, B.P., 2001, Relations among river stage, rainfall, ground-water levels, and stage at two Missouri River floodplain wetlands: U.S. Geological Survey Water Resources Investigative Report 01-4123, 18 p.

Knowlton, M.F., and Jones, J.R., 1997, Trophic status of Missouri River flood plain lakes in relation to basin type and connectivity: Wetlands, v. 17, p. 468-475.

Knowlton, M.F., and Jones, J.R., 2000, Seston, light, nutrients and chlorophyll in the Lower Missouri River, 1994-1998: Journal of Freshwater Ecology, v. 15, p. 283-297.

Knowlton, M.F., and Jones, J.R., 2003, Connectivity influences temporal variation of limnological conditions in Missouri River scour lakes: Lake and Reservoir Management, v. 19 , p. $160-170$.

Latka, D.C., Nesteler, J., and Hesse, L.W., 1993, Restoring physical habitat in the Missouri River-a historical perspective, in Hesse, L.W., Stalnaker, C.B., Benson, N.G., and Zuboy, J.R., eds., Proceedings of the symposium on restoration planning for the rivers of the Mississippi River ecosystem: National Biological Survey Report 19, p. 350-359.

Mazourek, J.C., 1998, Dynamics of seed bank and vegetation communities in existing and potential emergent marshes in the Missouri River flood plain: Columbia, Mo., University of Missouri, Master's thesis, $131 \mathrm{p}$.

McColpin, A., 2002, Waterbird use of lower Missouri River floodplain wetlands: Columbia, Mo., University of Missouri, Master's thesis, $256 \mathrm{p}$.

National Research Council, 1999, Downstream-adaptive management of Glen Canyon Dam and the Colorado River Ecosystem: Washington, D.C., National Academies Press, $230 \mathrm{p}$.

National Research Council, 2002, The Missouri River ecosystem-exploring the prospects for recovery: Washington, D.C., National Academies Press, 176 p.

National Research Council, 2003, Science and the greater Everglades ecosystem restoration-an assessment of the critical ecosystem studies initiative: Washington, D.C., National Academies Press, 87 p. 
Palmer, M.A., Bernhardt, E.S., Allen, J.D., Lake, P.S., Alexander, G., Brooks, S., Carr, J., Clayton, S., Dahm, C.N., Follstad Shah, J., Galat, D.L., Gloss, S., Goodwin, P., Hart, D.D., Hassett, B., Jenkinson, R., Kondolf, G.M., Lave, R., Meyer, J.L., O'Donnell, T.K., Pagano, L., and Sudduth, E., 2005, Standards for ecologically successful river restoration: Journal of Applied Ecology, v. 42, p. 208-217.

Rhoads, B.L., Wilson, D., Urban, M.L., and Herricks, E.E., 1999, Interaction between scientists and nonscientists in community-based watershed management-emergence of the concept of stream naturalization: Environmental Management, v. 24, p. 297-308.

Ruhe, R.V., 1975, Geomorphology-geomorphic processes and surficial geology: Boston, Houghton Mifflin Company, $246 \mathrm{p}$.

Sargent, J.C., and Galat, D.L., 2002, Fish mortality and physiochemistry in a managed wetland along the Lower Missouri River: Wetlands Ecology and Management, v. 10, p. 113-119.

Sparks, R.E., Nelson, J.C., and Yin, Y., 1998, Naturalization of the flood regime in regulated rivers: BioScience, v. 48, p. 706-720.

Sparks, R.E., 1995, Need for ecosystem management of large rivers and their flood plains: BioScience v. 14, p. 168-182.

Swanson, D.L., 1999, Avifauna of an early successional habitat along the Middle Missouri River: Jamestown, N. Dak., Prairie Naturalist, v. 31, p. 145-164, accessed February, 2006 at URL http://www.npwrc.usgs.gov/resource/birds/ avihab/avihab.htm.

U.S. Army Corps of Engineers, 1998, Reservoir regulation studies-daily routing model studies, in, Master Water Control Manual Missouri River Review and Update Study, v. 2A: Omaha, Nebr., U.S. Army Corps of Engineers, Northwest Division Missouri River Region, 139 p.

U.S. Army Corps of Engineers, 1999, Missouri River bank stabilization and navigation fish and wildlife mitigation project, definite project report with integrated environmental assessment-Overton Bottoms mitigation site, Volume 1: Kansas City, Mo., U.S. Army Corps of Engineers, Kansas City District, 53 p.

U.S. Army Corps of Engineers, 2002, Missouri River fish and wildlife mitigation project, draft supplemental environmental impact statement: Kansas City, Mo., U.S. Army Corps of Engineers, Kansas City District, 258 p.

U.S. Army Corps of Engineers, 2004a, Upper Mississippi River system flow frequency study final report: Rock Island, Ill., 40 p. + appendices.
U.S. Army Corps of Engineers, 2004b, Missouri River shallow water habitat report: Omaha, Nebr., U.S. Army Corps of Engineers, Northwestern Division, 57 p.

U.S. Army Corps of Engineers, 2004c, Missouri River bank stabilization and navigation project, fish and wildlife mitigation project, annual implementation report 2004: U.S. Army Corps of Engineers, Omaha and Kansas City District, 63 p.

U.S. Fish and Wildlife Service, 2003, Amendment to the 2000 biological opinion on the operation of the Missouri River Main Stem Reservoir system, operation and maintenance of the Missouri River Bank Stabilization and Navigation Project, and operation of the Kansas River Reservoir System: Minneapolis, Minn., U.S. Fish and Wildlife Service, 308 p.

Walters, C., 1986, Adaptive management of renewable resources: New York, Macmillan Publishers, 374 p.

Walters C., 1997, Challenges in adaptive management of riparian and coastal systems: Conservation Ecology, v. 1, 22 p., accessed February, 2006 at URL http://www.consecol. org/vol1/iss2/art1.

Williams, A.K., Ratnaswamy, M.J., and Renken, R.B., 2001, Impacts of a flood on small mammal populations of Lower Missouri River flood plain forests: American Midland Naturalist, v. 146, p. 217-221.

Wissmar, R.C., and P.A., Bisson, eds., 2003, Strategies for restoring river ecosystems: sources of variability and uncertainty in natural and managed systems: Bethesda, Md., American Fisheries Society, 263 p. 


\section{Surficial Alluvium and Topography of the Overton Bottoms North Unit, Big Muddy National Fish and Wildlife Refuge in the Missouri River Valley and its Potential Influence on Environmental Management}

By John Holbrook, Greg Kliem, Chima Nzewunwah, Zen Jobe, and Ron Goble

Chapter 2 of

Science to Support Adaptive Habitat Management: Overton Bottoms North Unit, Big Muddy National Fish and Wildlife Refuge, Missouri

In cooperation with the U.S. Fish and Wildlife Service

Scientific Investigations Report 2006-5086

U.S. Department of the Interior

U.S. Geological Survey 


\section{Contents}

Abstract
Introduction nowi Valley and its Alluvium
The Missouri
The Bedrock Valley

\section{Figures}

1. Map showing Missouri River Overton Bottoms area ....................................................... 20

2. Schematic, block diagram of the Lower Missouri River Valley bottom .......................... 22

3-4. Geologic maps showing-

3. Surficial deposits in the Rocheport, Missouri 7.5' quadrangle ..................................23

4. Overton Bottoms North Unit ......................................................................................24

5-6. Charts showing-

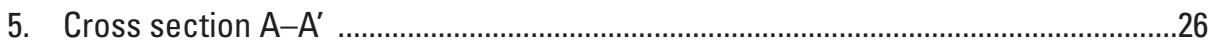

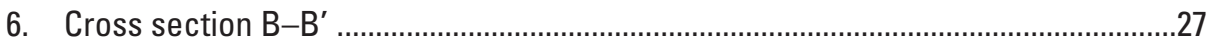

7-8. Photographs showing-

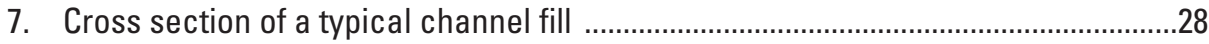

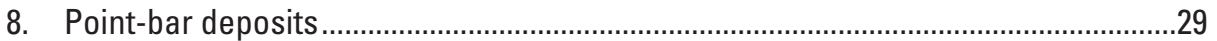

\section{Tables}

1. Optically stimulated luminescence results from Overton Bottoms North Unit

Holbrook, J., Kliem, G., Nzewunwah, C., Jobe, Z., and Goble, R., 2006, Surficial alluvium and topography of the Overton Bottoms North Unit, Big Muddy National Fish and Wildlife Refuge in the Missouri River Valley and its potential influence on environmental management, chap. 2 of Jacobson, R.B., ed., Science to support adaptive habitat management-Overton Bottoms North Unit, Big Muddy National Fish and Wildlife Refuge, Missouri: U.S. Geological Survey, Scientific Investigations Report 2006-5086, p. 17-31. 


\title{
Chapter 2 \\ Surficial Alluvium and Topography of the Overton Bottoms North Unit, Big Muddy National Fish and Wildlife Refuge in the Missouri River Valley and its Potential Influence on Environmental Management
}

\author{
John Holbrook', Greg Kliem', Chima Nzewunwah², Zane Jobe', and Ron Goble ${ }^{3}$
}

\begin{abstract}
We mapped surficial sediments in the Overton Bottoms North Unit of the Big Muddy National Fish and Wildlife Refuge in Missouri using allostratigraphic techniques. This entailed identification of surficial features indicative of sedimentary allounits from remote-sensed data, then testing these predicted units by drilling for anticipated sediments. From the mapping we concluded that Overton Bottoms is characterized by numerous cross-cutting meander-loop allounits. Each meander-loop allounit contains a channel-fill unit and a pointbar unit, and most are dissected by numerous chute-channelfill units.
\end{abstract}

Surficial mapping of flood-plain deposits in the Missouri River Valley provides insights into channel history, and has implications for management of environmental resources. The deposits of the Missouri River in the Overton Bottoms area record deposition from a low-sinuosity meandering system which was prone to development of numerous side-channel chutes. These side-channel chutes commonly enclosed islands, giving the channel an appearance similar to that recorded in late 19th century maps. Further, the distribution of channel-fill and point-bar units has a potentially strong effect on interaction of surface and ground water. Channel fills are characterized by up to $7 \mathrm{~m}$ (meters) of fine-grained low-permeability strata which can provide a substantial barrier to infiltration of surface water. The thinner and more permeable section of finegrained deposits that tends to cap point-bar units is more conducive to communication of surface and ground waters. The areas above channel-fill units are thus better candidates for natural and engineered wetlands and are more likely to support

\footnotetext{
${ }^{1}$ University of Texas at Arlington, Arlington, Texas

${ }^{2}$ University of Texas, El Paso, Texas

${ }^{3}$ University of Nebraska, Lincoln, Nebraska
}

standing water needed for wetland biota. The point-bar units will be more prone to rapid infiltration of surface waters, and will tend toward comparatively xeric species.

\section{Introduction}

The surficial alluvium of the Missouri River Valley in Overton Bottoms forms the foundation for the physical and the biological aspects of the flood-plain ecosystem. It determines the parent material within which soils form, determines the moisture retention and infiltration capacity of that soil, determines the local potential and rate of surface- and ground-water interaction, and provides the medium through which shallow ground water flows. Through these physical controls, surficial alluvium serves as an important control on habitat distributions.

The surficial alluvium is formed from the long-term channel and flood-plain processes of the Missouri River, and is thus a partial record of landforms generated and destroyed as the channel migrated across its valley. In this respect, the alluvium and the topography of the flood plain are closely related. Together, the alluvium and topography of the flood plain provide a record of recent river form and processes.

This study examines the surficial flood-plain stratigraphy of the Overton Bottoms North Unit of the Big Muddy National Fish and Wildlife Refuge (fig. 1) and evaluates its effects on biotic and physical processes at and just beneath the flood-plain surface. This chapter addresses three key questions: What is the distribution of surficial materials within the Overton Bottoms North Unit and what is its relationship to flood-plain topography? What channel processes controlled this distribution? What potential effects can surficial alluvium and topography impose upon present-day ecosystems and land management? 


\section{The Missouri Valley and its Alluvium}

\section{The Bedrock Valley}

In Kansas and Missouri, the Missouri River Valley is incised through a series of mixed carbonate and siliciclastic bedrock formations of late Paleozoic age. In the Overton Bottoms area, bedrock is dominantly Mississippian limestone. The bedrock valley floor is reported to reach maximum depths of 30-36.5 m beneath the flood-plain surface (Emmett and Jeffery, 1969).

The modern drainage of the Missouri River formed as continental ice sheets diverted north and east-flowing streams in Montana, the Dakotas, Kansas, Iowa and Missouri, allowing them to be captured by the south- and south-easterly flowing melt water system along the glacial ice front (Bluemle, 1972; Prather and others, 1998; Galloway, 2005). The present-day bedrock valley in the Overton Bottoms area is assumed to be at the position of an ice-front channel that drained the melt water from repeated southward-advancing Pleistocene ice sheets (Heim and Howe, 1963). Prior to the Pleistocene, a smaller channel with headwaters in western Missouri and eastern Kansas is thought to have passed eastward through this valley toward the modern St. Louis area (Heim and Howe, 1963). Detailed information on the early bedrock valley in the Overton Bottoms reach does not exist, but records of time and location of sediment input into the Gulf of Mexico suggest that the Missouri River likely coursed through this reach throughout Pleistocene time (Prather and others, 1998; Galloway, 2005).

\section{The Alluvial Valley Fill}

The surficial alluvium described over most of the Lower Missouri River Valley consists of medium-sand to clay-sized sediments of Holocene age, deposited over coarser sand and gravel deposits (Kelly and Blevins, 1995; Emmett and Jeffery, 1969). These coarser sand and gravel deposits are presumed to be accumulated outwash strata (Dahl, 1961), although no dates exist to confirm this through the Missouri segments of the river. Indirect evidence, however, supports this assertion. Sheets of Pleistocene wind-blown loess, presumed to have been derived from outwash deposits, flank the Missouri River

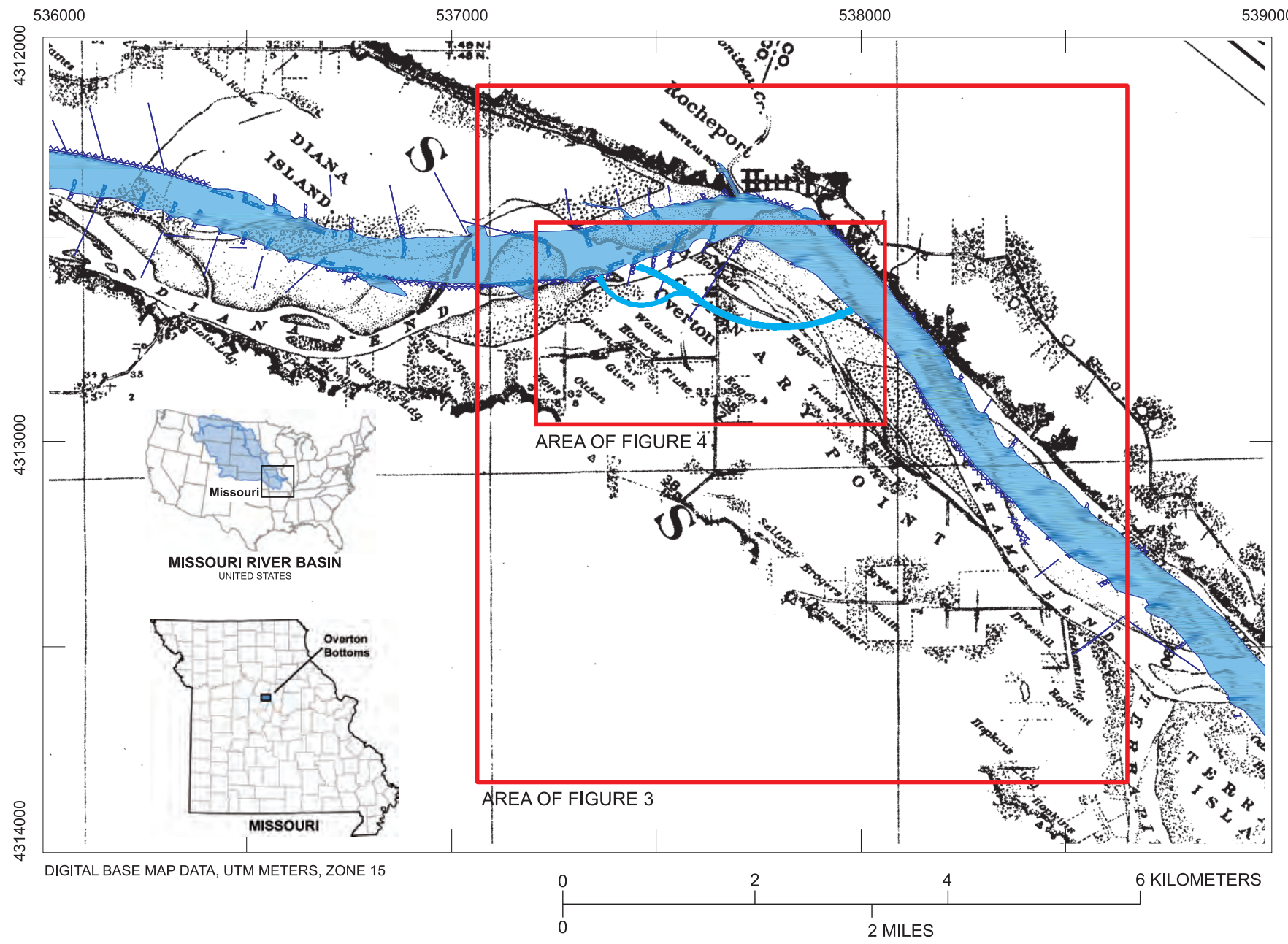

Figure 1. The modern Missouri River in the Overton Bottoms area is superimposed on an historic map of the pre-modification channel. (Modified after: Missouri River Commission, 1894) 
Valley throughout Missouri, and are cited as indirect evidence that Pleistocene outwash once passed through the valley locally (Ruhe, 1983; Grimley, 2000; Forman and Pierson, 2002). Furthermore, the first confirmed channel deposits of Pleistocene age were recently mapped roughly $200 \mathrm{~km}$ (kilometers) upstream near the town of Carrollton, Missouri (Dolde and others, in press; Main and others, 2005). In addition, fine alluvium that is capped by Peoria Loess (Bretz, 1965) and carbon dated at approximately $25 \mathrm{ka}$ (thousands of years before present; Nzewunwah, 2003) are recognized in the valley near Malta Bend, Missouri, and are presumed to record some form of Pleistocene slackwater deposition within the valley (Bretz, 1965; Nzewunwah, 2003). Together, these confirm that large Pleistocene rivers did pass down the valley and that their deposits have been preserved in places at the surface. This supports the assumption that Pleistocene outwash deposits exist beneath surficial Holocene sediments.

Holocene sediments dominate the surficial strata within the valley, indicating that river migration has been effective in eroding or covering most of the surficial Pleistocene deposits in most areas. The complete thickness of the Holocene section is unknown in most parts of the Missouri River Valley. The Holocene section, however, is at least $10 \mathrm{~m}$ thick, based on the maximum recorded depth of surficial channel fills (Amadi, 2004).

Surficial Holocene strata record a history of transition from a meandering river to what has traditionally been referred to as an island-braided river in a $50 \mathrm{~km}$ alluvial reach between Lexington, Missouri and Miami Station, Missouri, approximately $200 \mathrm{~km}$ upstream of Overton Bottoms (Nzewunwah, 2003; Amadi, 2004; Holbrook and others, 2005). Deposits between approximately $3.5 \mathrm{ka}$ and at least $5.0 \mathrm{ka}$ within this alluvial part of the valley were deposited within a singlechannel high-sinuosity meandering river system (Holbrook and others, 2005). Starting somewhat abruptly at $3.5 \mathrm{ka}$, the river here began to take on a more island-rich form. By approximately $1.5 \mathrm{ka}$, the river had adapted the dominantly island-braided appearance known to be typical of the historic pre-modification channel (fig. 1). Variation of the channel patterns over time in narrow, bedrock-confined reaches like that at Overton Bottoms is unknown, and is the subject of current research.

\section{Methods}

We mapped surficial strata in the Overton Bottoms during two field seasons using allostratigraphic techniques. Allostratigraphy defines allounits (map units) based on recognition and delineation of their bounding discontinuities (for example, erosional contacts, or traceable soil horizons; NACSN, 1983; Jacobson and others, 2003). Examples of discontinuity-bound sedimentary bodies that may be mapped as allostratigraphic units include: ox-bow lake/channel fills, point-bar fills, natural levees, levee splays, buried alluvial deposits from a previous stage of river history, deposits underlying terraces, and a combination of such allounits.

The first step in the mapping procedure entails observation of topographic maps, aerial photographs, digital elevation models, satellite imagery, and existing soil maps for recognition of landforms characteristic of likely depositional units and landform affinities. Basic assumptions of depositional style derived from these observations are used in conjunction with established sedimentary architectural models to identify likely allostratigraphic mapping units within the valley alluvium. Construction of a series of "hypothesis maps" of allostratigraphic units follows based on the sedimentary models and landforms.

The architectural model used to define allounits in the Missouri River Valley bottom is based on Miall, 1996. Miall defines a series of seven discontinuity-bound allounits that make up the depositional elements of fluvial flood plains. These units are defined by their geometry and their fill, and include: channel fills, lateral-accretion elements, downstream macroforms, overbank fines, gravity flows, sandy bedforms, and laminated sand sheets. The most common features mappable at the 1:24,000 scale in the flood plain of a large meandering-to-braided system, such as the Missouri River, are channel fills, point-bar units that were deposited by lateral accretion, and overbank fine sediments. These units are illustrated and described in figure 2. Overbank fines were only distinguished from underlying deposits where they were consistently over 2 $\mathrm{m}$ thick or where splays were identified from the topography. In cases where overbank fine-sediment thickness was less than $2 \mathrm{~m}$, fine sediments were not mapped separately, but were included with the underlying allounit. Adjacent channel-fill and point-bar allounits were commonly grouped into a single meander-loop allounit. A meander-loop allounit consists of the point-bar allounit combined with the channel fill of the outer bend of the point bar, and smaller channel fills which incise into the top of the point bar.

The next step in surficial mapping was to test landformbased hypotheses by sampling and describing sediments in drill holes. Allounits defined on hypothesis maps typically imply characteristic grain-size distributions and sedimentary origin. For instance, an arc-shaped swale is usually inferred to be an abandoned channel which is nearly filled. The fill is expected to have a fine-grain-size distribution dominated by silt- and clay-sized grains (fig. 2). If drilling confirms this prediction, the abandoned-channel-fill hypothesis is supported. If not, it is falsified and a new hypothesis is required. Continued hypothesis testing eventually results in a unique solution that is prepared as a final map of allounit distribution and grainsize characteristics.

Mapping during the first season focused on developing a general 1:24,000-scale map for the entire Rocheport 7.5' quadrangle (Nzewunwah and others, 2004; fig. 3). Aerial photographs were used with digital elevation models to assess areas consistent with allounit definitions. These map units were each tested by drilling using hand augers. Drilling samples were logged at $10 \mathrm{~cm}$ (centimeters) intervals and described for 


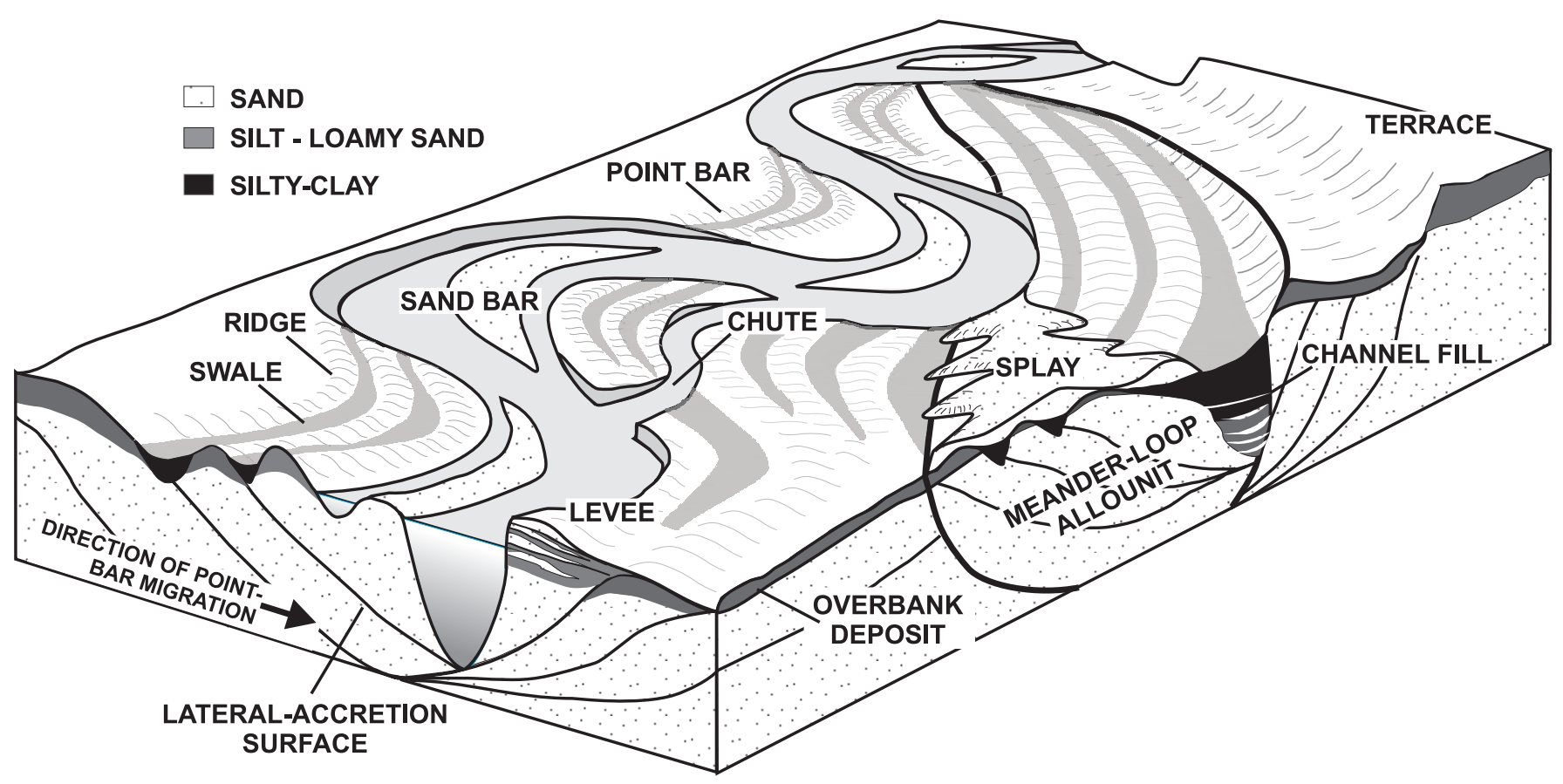

Figure 2. Architecture of the Lower Missouri River Valley bottom, after Miall (1996). Meander loops are formed by lateral migration of point bars and smaller lateral bars that are attached to the channel boundary on the inside of meander loops. Lateral migration occurs in stages, producing a series of lateral-accretion surfaces. Ridges and swales on point bars occur approximately parallel to the channel, and likely result from a combination of processes, including flow separation accompanying lateral migration during individual floods, preferential deposition in vegetation bands (McKenney and others, 1995), and erosion in overflow channels or chutes. Point bars tend to decrease in grain size upward from sand to fine gravel at the base to silt and clay at the top because shear stress of the flow decreases up the lateral accretion surface on which the bar grows. As banks are topped by floodwaters, the coarsest part of the suspended load is deposited along the channel margins forming natural levees, and the finer part of the suspended load is deposited more evenly across the point bars as clay-rich overbank mud veneers. Sandrich parts of point bars are typically veneered by both silt-rich natural levee and clay-rich overbank deposits. Periodically, flood waters locally breach the natural levee (or engineered levees), and suspended load and bed load sediments will escape the channel and spread out onto the adjacent point bars to form a delta-type deposit known as a crevasse splay. Point bars are typically terminated on their outer bend against a channel-fill allounit, and are defined on their inner side by a sharp surface that truncates other deposits and marks a change in ridge-andswale trend. Channel fills record sedimentation in channels that have been abandoned from the active flow by local meander-bend cut off, or shifting of the entire channel to a new location on the flood plain (avulsion). Channels will be cut off or avulse because a new location provides a steeper and more favorable course for channel flow. Flow is strongest in the abandoned channel during the early parts of the abandonment phase. Channel fills are thus generally floored with the coarse material typical of the bed load normally carried by the active river. If the channel is abandoned abruptly, and active flow does not return, the remainder of the channel will fill with clay and silt deposits in an ox-bow lake setting. If the channel is periodically reoccupied by the main channel, fill may be of any grain size carried by the river, and will alternate in grain size in direct proportion to flow strength during reoccupation. Channel fills are recognized as long arcuate-tostraight swales with widths equal to or less than the forming channel. Channels with dimensions substantially less than the full size of the modern Missouri River, as well as contemporary channel fills, are identified as chute channels. Apparent channels which follow ridge-and-swale topography, but are no wider than other swales, or include only silt and clay fill, are considered to be overbank-swale fills rather than channels. 
grain size (as soil-textural class; Soil Survey Division Staff, 1993), color, oxide and salt content, and organic components. Field work during the second season was performed as a class project at the University of Texas at Arlington, and entailed construction of a detailed surficial geologic map and two cross sections depicting allounits through the central part of the Overton Bottoms North Unit area (figs. 4-6). Cross sections were constructed from 36 hand-auger drill holes, and were used as the basis for refining the surficial map of the prior year. The cross sections were oriented to provide information useful to coordinated ground-water and vegetation studies.

Four sand samples were collected during the second year for optically stimulated luminescence (OSL) dating (figs. 4-6). We collected each sample from fine sand layers in the upper part of point-bar allounits using a Missouri sampler, a device specifically designed for collecting OSL samples from drill holes within the Missouri River Valley. The Missouri sampler attaches to the bottom of the Dutch auger system, and employs a check-valve system to retain saturated sand samples within an attached opaque PVC pipe, which is driven into and then extracted from the sediment at the bottom of the auger hole.

OSL samples were processed at the University of Nebraska Luminescence Geochronology facility. Sample preparation was carried out under amber-light conditions. Samples were wet sieved to extract the 90-150 $\mu \mathrm{m}$ (micrometer) fraction, and then treated with acid to remove carbonates. Quartz and feldspar grains were extracted by flotation and treated again with acid. Samples were then resieved and the $<90 \mu \mathrm{m}$ fraction discarded to remove residual feldspar grains. The remaining etched quartz grains were mounted on $1 \mathrm{~cm}$

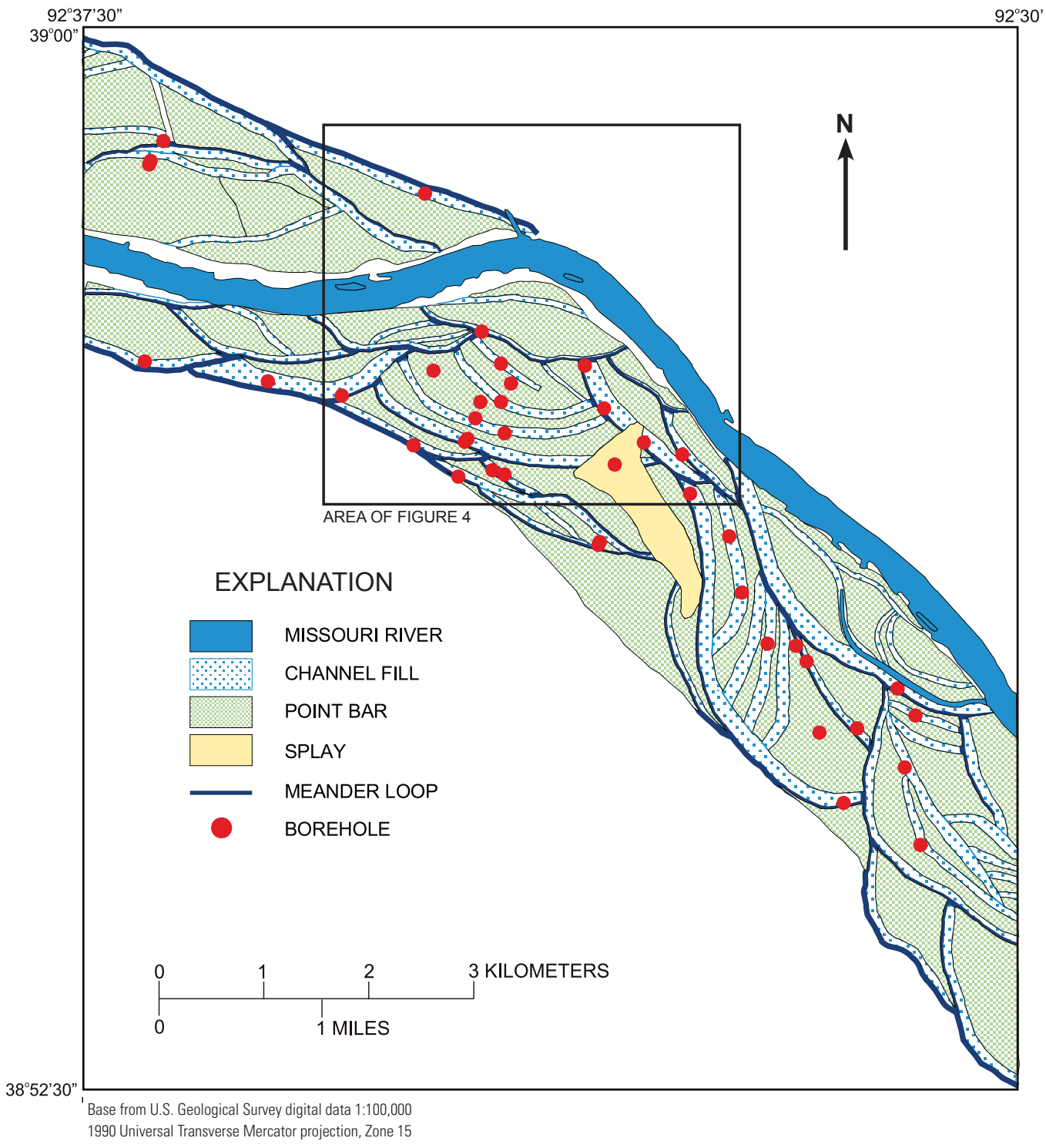

Figure 3. Surficial deposits in the Rocheport, Missouri 7.5' quadrangle. Blue linear features record channel-fill allounits, and green records point-bar allounits. Dark outlines define meander-loop allounits. (Nzewunwah and others, 2004) 
aluminum disks for analysis. Chemical analyses were carried out by Chemex Labs, Inc., Sparks, NV, using a combination of Inductively Coupled Plasma Mass Spectrometry and Inductively Coupled Plasma Atomic Emission Spectrometry. Dose-rates were calculated using the method of Aitken (1998) and Adamiec and Aitken (1998). The cosmic contribution to the dose-rate was determined using the techniques of Prescott and Hutton (1994).

OSL analyses were carried out on a Riso Automated OSL Dating System Model TL/OSL-DA-15B/C, ${ }^{1}$ equipped with blue and infrared diodes, using the Single Aliquot Regenerative Dose technique (Murray and Wintle, 2000). A preheat of $240^{\circ} \mathrm{C}$ for 10 seconds was used, with a cutheat of $160^{\circ} \mathrm{C}$, based upon a preheat plateau test between 180 and $280^{\circ} \mathrm{C}$ on calibra- tion sample UNL988 (table 1). A dose-recovery test (Murray and Wintle, 2003) on another sample (UNL985) recovered $2.49 \pm 0.06$ Gray (Gy, a measure of optical dose, or $1 \mathrm{~J} / \mathrm{kg}$, joules per kilogram) from an applied dose of $2.52 \mathrm{~Gy}$. Thermal transfer for the same sample was $0.04 \pm 0.03 \mathrm{~Gy}$. Examination of the growth curves for the samples showed the samples to be well below saturation. Optical ages were based upon a minimum of 20 aliquots. Individual aliquots were monitored for quality control and those deemed unacceptable were discarded from the data set prior to averaging.

\footnotetext{
${ }^{1}$ Any use of trade, product, or firm names is for descriptive purposes only and
} does not imply endorsement by the U.S. Government.

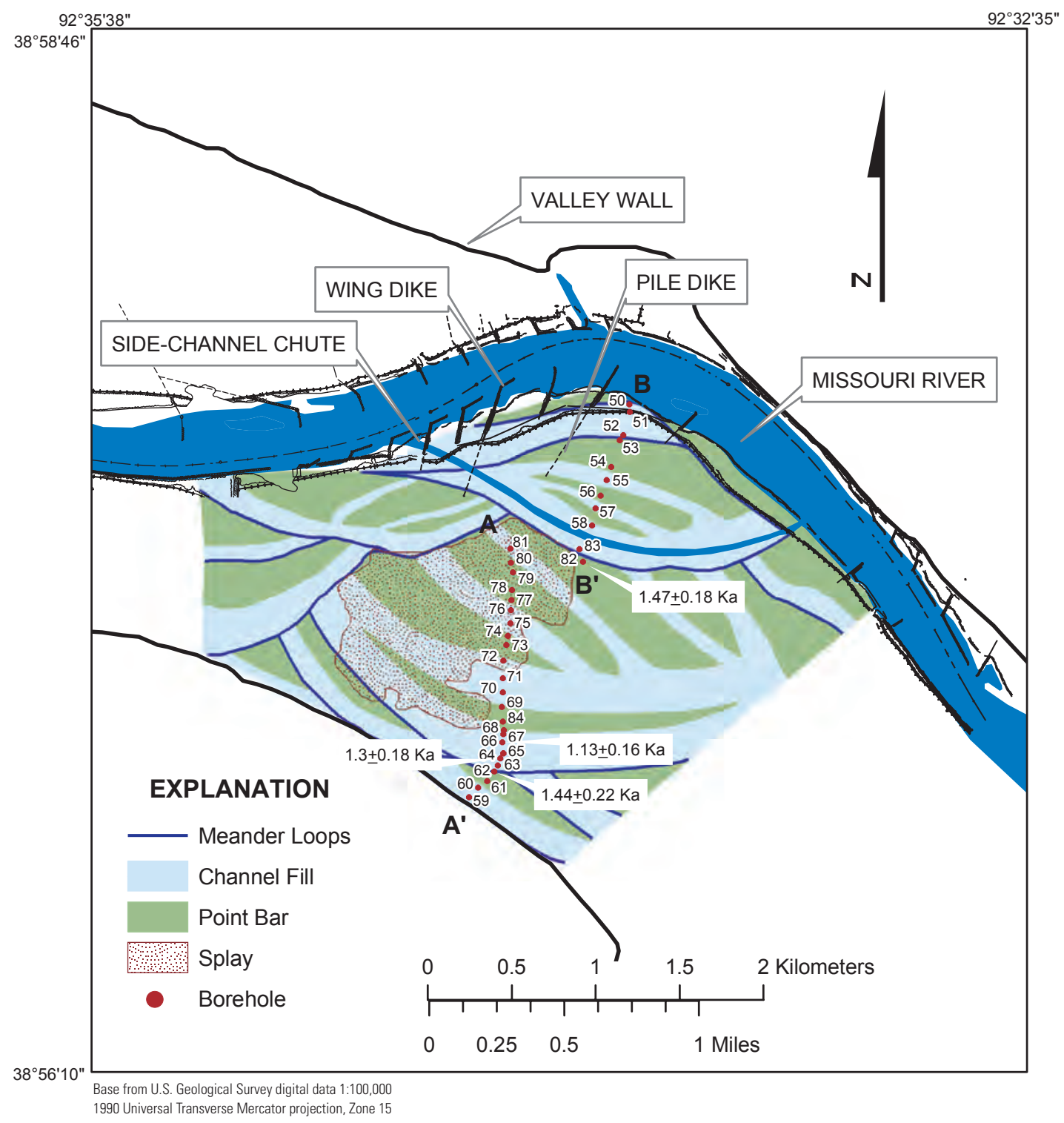

Figure 4. Overton Bottoms North Unit. Blue linear units are channel-fill allounits, and green units are point-bar allounits. Dark lines outline meander-loop allounits. Dots on the map are locations of boreholes used for this study. The location of cross sections $A-A^{\prime}$ and $B-B^{\prime}$ are indicated on the map by the equivalent trend of borehole locations. 


\section{Results}

The generalized map (fig. 3) shows approximately 21 meander-loop allounits. Each meander loop is defined on the outside arc by a channel-fill allounit that wraps around a single point-bar allounit. The point-bar allounit typically has multiple smaller channel-fill allounits within it. These units represent fill in side-channel chutes or over-flow channels on point-bar swales. Channel-fill allounits within a point-bar allounit are typically oriented parallel to one another, but at angles to those in adjacent meander loops.

The detailed map and cross sections of Overton Bottoms North offer a higher-resolution view of the surficial stratigraphy of the area (figs. 4-6). The thickest channel-fill allounits within any meander loop are those defining the outer arc of the loop. These may be up to $7 \mathrm{~m}$ thick, but are usually less than 5 $\mathrm{m}$. Channel fills crossing the point bar are generally thinner $(<$ $4 \mathrm{~m}$ ), and incise the underlying point-bar surface. Channel fills tend to comprise mixtures of fine-grained sediments, grading from loam to loamy sand at the base, to clay to silt loam in the upper parts. Most channel-fill allounits also include a definable stratigraphy with layers of contrasting and alternating grain sizes (figs. 5-7). In contrast to chute-channel fills, swalefills are substantially thinner $(<1.5 \mathrm{~m})$, and drape point bars without local incision. In many cases swale-fills grade laterally into clayey, overbank units that cap point bars.

Point-bar allounits are floored by well-sorted to slightly loamy cross-bedded fine sand (fig. 8). These units are thicker than our ability to auger and the total depth of the units is unknown. Point-bar allounits typically grade upward into loam and silt loam layers that are usually between 1-2 m thick. Silty layers are commonly capped abruptly by mud veneers composed of clay and silty clay, or layers with highly mixed textures. Thickness of these capping units is highly variable, but is typically less than $2 \mathrm{~m}$, and is mostly less than $1 \mathrm{~m}$. These units constitute overbank, fine deposits which were combined with point-bar allounits for mapping purposes, as they generally are of insufficient thickness and extent to warrant mapping as a separate allounits. A large splay deposit is grouped with overbank fines and is indicated by a stippled pattern on the map (fig. 4). The splay is well defined topographically and the sandy sediment associated with it is apparent in cores, however it has been mixed with finer sediment, apparently through deep plowing, and does not have clearly definable stratigraphic contacts with underlying sediments.

The detailed cross section A-A' (fig. 5) is on the south and west side of the recently excavated side-channel chute, and crosses two meander-loop allounits. The meander loop closest to the valley wall is dated at $1.4 \pm 0.22 \mathrm{ka}$ based on an OSL date from sand collected on the oldest preserved pointbar remnants beneath the truncating channel of a younger loop at $5 \mathrm{~m}$ depth in borehole 62 (table 1). The channel-fill allounit bounding this meander loop is up to $7 \mathrm{~m}$ thick (boreholes 59-60); it is composed mostly of loam and silt-loam sediment, with a $1 \mathrm{~m}$ thick unit at the base composed mostly of loam to sandy loam.

Moving toward the present-day channel, the next meander loop is bounded by a channel-fill allounit that is as much as $6 \mathrm{~m}$ thick (boreholes 62-67). This channel-fill allounit is dominantly loamy sediment, similar to the channel in boreholes 59-60, but it has a distinct clay unit between the loamy and sandy sediment (boreholes 62 and 63). This channel fill is separated on the surface from an adjacent and large chutechannel fill (boreholes 70-72) by a segment of point-bar allounit (boreholes 68, 84, and 69; fig. 5). The chute-channel fill is only $4 \mathrm{~m}$ thick; it is dominated by clay and silty clay sediment, and merges upstream and downstream with the larger channel fill penetrated by boreholes 62 and 63 (fig. 4). The point-bar allounit is crossed diagonally by two narrow chute channels (fig. 5) of no more than $4 \mathrm{~m}$ thickness each that are dominated by sandy-loam sediments. The youngest part of this meander loop is dated in boreholes 64 and 66 at $1.13 \pm 0.16 \mathrm{ka}$ and $1.3 \pm 0.18 \mathrm{ka}$, respectively (fig. 5, table 1). The oldest part of this point bar is dated in borehole 82 within cross section B-B' at $1.47 \pm 0.18 \mathrm{ka}$ (fig. 6 , table 1 ). The point-bar allounits in both meander loops are capped by $<2$ $\mathrm{m}$ of fine-grained silt-loam-to-clay overbank sediment. These capping sediments are stratified and include a layer of clay to silty clay overlain by a layer of highly mixed strata with variable grain size. A topmost muddy unit above this mixed layer, which is not sufficiently thick to be distinguished on this cross section, overlies agriculturally disturbed soil horizons, and is probably overbank sediment from floods since 1993.

Table 1. Optically stimulated luminescence results from Overton Bottoms North Unit.

[m, meters; \%, percent; ppm, parts per million; Gy, optical dose in grays; ka, thousands of years; s.d., standard deviation]

\begin{tabular}{|c|c|c|c|c|c|c|c|c|c|c|c|}
\hline $\begin{array}{l}\text { Univ. of Nebraska } \\
\text { Lincoln lab } \\
\text { number }\end{array}$ & $\begin{array}{l}\text { Univ. of Texas } \\
\text { Arlington } \\
\text { field number }\end{array}$ & $\begin{array}{c}\text { Burial } \\
\text { depth } \\
\text { (m) }\end{array}$ & $\begin{array}{c}\mathrm{H}_{2} \mathrm{O}^{*} \\
\text { content } \\
(\%)\end{array}$ & $\begin{array}{c}\mathrm{K}_{2} \mathbf{O} \\
\text { content } \\
(\%)\end{array}$ & $\begin{array}{c}\mathrm{U} \\
\text { content } \\
\text { (ppm) }\end{array}$ & $\begin{array}{c}\text { Th } \\
\text { content } \\
\text { (ppm) }\end{array}$ & $\begin{array}{c}\text { Cosmic } \\
\text { dose } \\
\text { (Gy) }\end{array}$ & $\begin{array}{c}\text { Dose } \\
\text { rate } \\
\text { (Gy/ka) }\end{array}$ & $\begin{array}{l}\text { Equivalent } \\
\text { dose } \\
\text { (Gy) }\end{array}$ & $\begin{array}{l}\text { Recup- } \\
\text { eration } \\
(\%)\end{array}$ & $\begin{array}{c}\text { Age } \\
(\mathrm{ka} \pm 2 \text { s.d. })\end{array}$ \\
\hline UNL985 & MOV OB-62 & 5.0 & 20.1 & 1.70 & 1.1 & 4.7 & 0.11 & $1.72 \pm 0.09$ & $2.47 \pm 0.11$ & 8.6 & $1.44 \pm 0.11$ \\
\hline UNL986 & MOV OB-64 & 3.7 & 13.0 & 1.87 & 1.3 & 5.2 & 0.13 & $2.06 \pm 0.09$ & $2.67 \pm 0.11$ & 7.5 & $1.30 \pm 0.09$ \\
\hline UNL987 & MOV OB-66 & 3.5 & 7.3 & 1.99 & 1.2 & 4.7 & 0.14 & $2.23 \pm 0.09$ & $2.59 \pm 0.10$ & 7.0 & $1.13 \pm 0.08$ \\
\hline UNL988 & MOV OB-82 & 3.7 & 6.5 & 1.82 & 1.1 & 4.3 & 0.13 & $2.06 \pm 0.08$ & $3.02 \pm 0.11$ & 4.4 & $1.47 \pm 0.09$ \\
\hline
\end{tabular}

\footnotetext{
* In-place moisture content
} 
Cross section B-B' crosses the excavated side-channel chute and continues north and east across the island that was formed by chute excavation (figs. 4,6 ). The excavated side-channel chute roughly follows a 6-7 m thick channelfill allounit that marks the outer boundary of a meander loop. This channel-fill unit (boreholes 58 and 83) has a complex layered fill of clay- and loam-dominated sediment, and is contiguous with two smaller branching chute channels (boreholes 55 and 57) that cross the island. Observations in the chute walls indicate that over most of its length, the side-channel chute was excavated through the channel-fill sediments into underlying fine-to-medium point-bar sand. The two smaller contiguous chute-channel units are approximately 3-4 m thick, respectively, and coarsen downward from loam to loamy sand. The unit in borehole 57 also has a prominent clay layer.

Another channel-fill allounit is prominent on the northwest margin of the island (boreholes 50 and 51). This channel-fill unit is visible in cross section at the western end of the wall of the excavated chute (fig. 7). In the boreholes, this channel is filled by loam, but in the chute cross section it is seen to contain large amounts of silt- and clay-size sediment, illustrating the amount of spatial variability that can be seen within channel-fill allounits.

Point-bar allounits on B-B' have slightly different stratigraphy than those on cross section $\mathrm{A}-\mathrm{A}^{\prime}$. The clay-rich overbank and the splay stratum capping point bars in cross section A-A' are absent from B-B'. The meander loops in cross section $\mathrm{B}-\mathrm{B}^{\prime}$ also cross cut the meander loops in cross section A-A', and are therefore stratigraphically younger. Presence of pile dikes that were buried in these strata and exposed during 2003 chute excavation support the idea that deposition of the sediments shown in section B-B' was still in process during channel modification of the early 1900's.

Some additional relations are apparent from these cross sections. The depth to generally well-sorted and permeable sand is highly variable across cross sections $\mathrm{A}-\mathrm{A}^{\prime}$ and $\mathrm{B}-\mathrm{B}$ '. $\mathrm{Up}$ to $7 \mathrm{~m}$ of fine-grained strata may be encountered in channel fills, but well-sorted sand is found generally about $2 \mathrm{~m}$ or less above point bars. Further, some relationship between topography and allounit is apparent. Cross section A-A' was constructed near the access road, where some topographic highs have been beveled by road construction activities. The

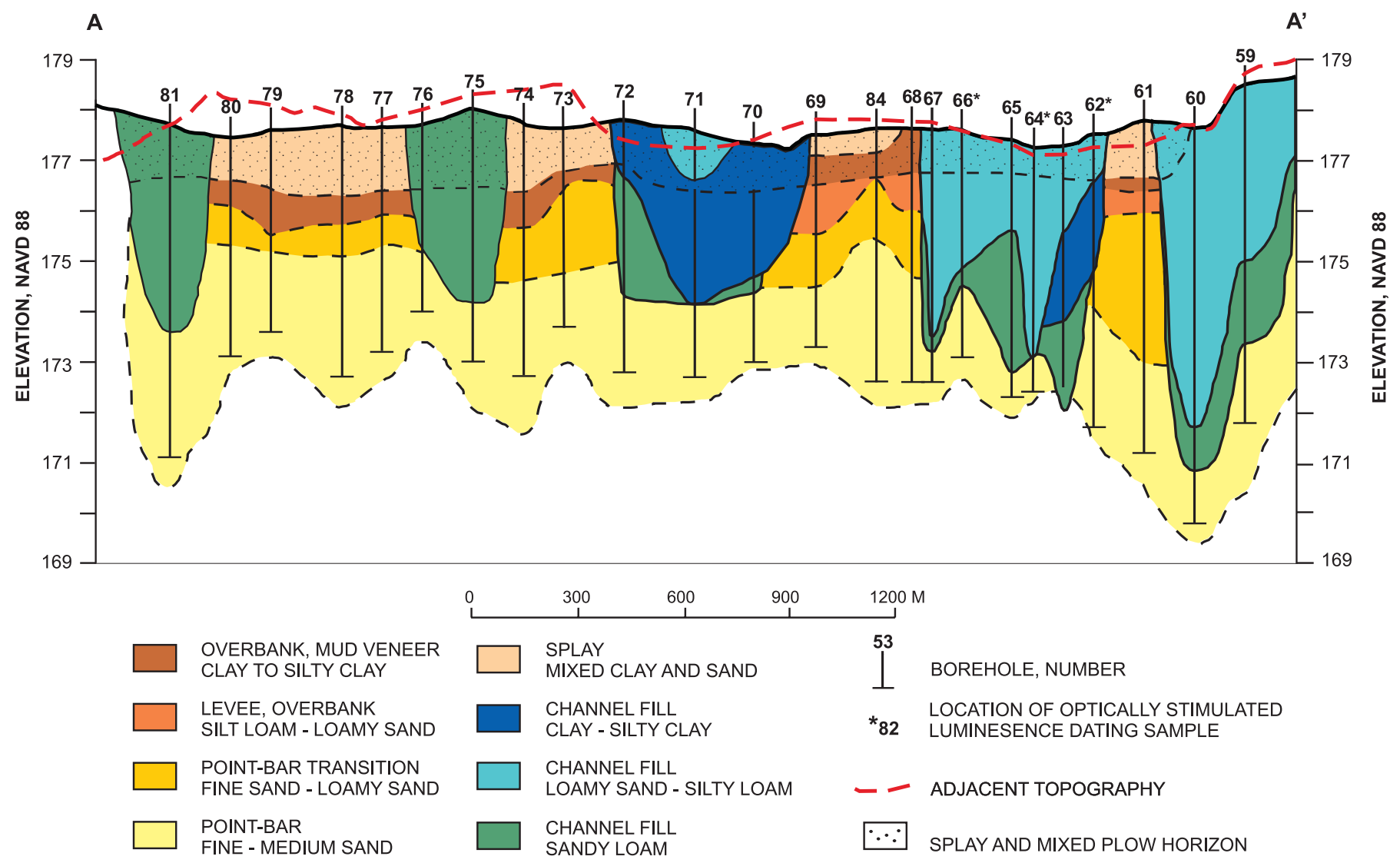

Figure 5. The cross section A-A' indicates channel-fill, point-bar, and meander-loop allounits mapped, and the grain-size and depositional environments which comprise these allounits. Mixed splay and underlying deposits are indicated with a stippled pattern that overlaps other unit designations. Splay deposits were not always clearly demarcated by contacts with underlying fine sediment, although particle size and topography indicated their presence. Sandy splay deposits from multiple deposition events were probably mixed with underlying sediments by agricultural plowing. 
dotted profile on this cross section illustrates the trend of topography away from the road where the topography is more intact. This profile and the accompanying map illustrate a very subtle coincidence between channel-fill allounits and lower topography.

\section{Depositional Model for Surficial Strata}

The surficial alluvium maps and cross sections at Overton Bottoms North provide insight into a general depositional model for this part of the Lower Missouri River Valley. Meander loops record point-bar growth and lateral shift of the channel, and thereby provide fundamental insight into river mechanics. Compared to surficial geology of the Lower Mississippi River Valley (for example, Fisk, 1944), Missouri River meander loops have lower amplitudes, are less sinuous, and are dominated by channel fills with coarser sediment. Mississippi River meander loops more typically migrated until they reached a threshold amplitude, after which the channel would cut across the flood plain to leave an ox-bow lake that would fill with clayey sediment. In contrast, meander-loop geometry of the Missouri River indicates that old channels mostly were abandoned gradually as new channels were formed by subparallel chutes. This process permitted weakened flow to be maintained through old channels as flow was steadily lost to a newly forming chute. The fill of gradually abandoned channels is thus a mixture of grain sizes, reflecting the intermittent flows. Local thick clay deposits (e.g., borehole 62 and 63 , cross section $\mathrm{A}-\mathrm{A}^{\prime}$ ) record intervals where a channel was temporarily blocked at the neck, and filling occurred in waters that remained still for extended periods. Channels dominantly filled by such "still water" conditions are rare and were only confirmed at two locations on the Rocheport quadrangle (fig. 3).

Dissection of point-bar allounits with numerous chutechannel-fill allounits (figs. 3, 4) indicate that a multi-channel river with many islands existed during most of the time represented by deposition of these sediments (1.47 ka). No substantial evidence for large in-channel bar formation typical of true braided rivers was found. Apparent islands record segments of previously developed point bars isolated between chute and

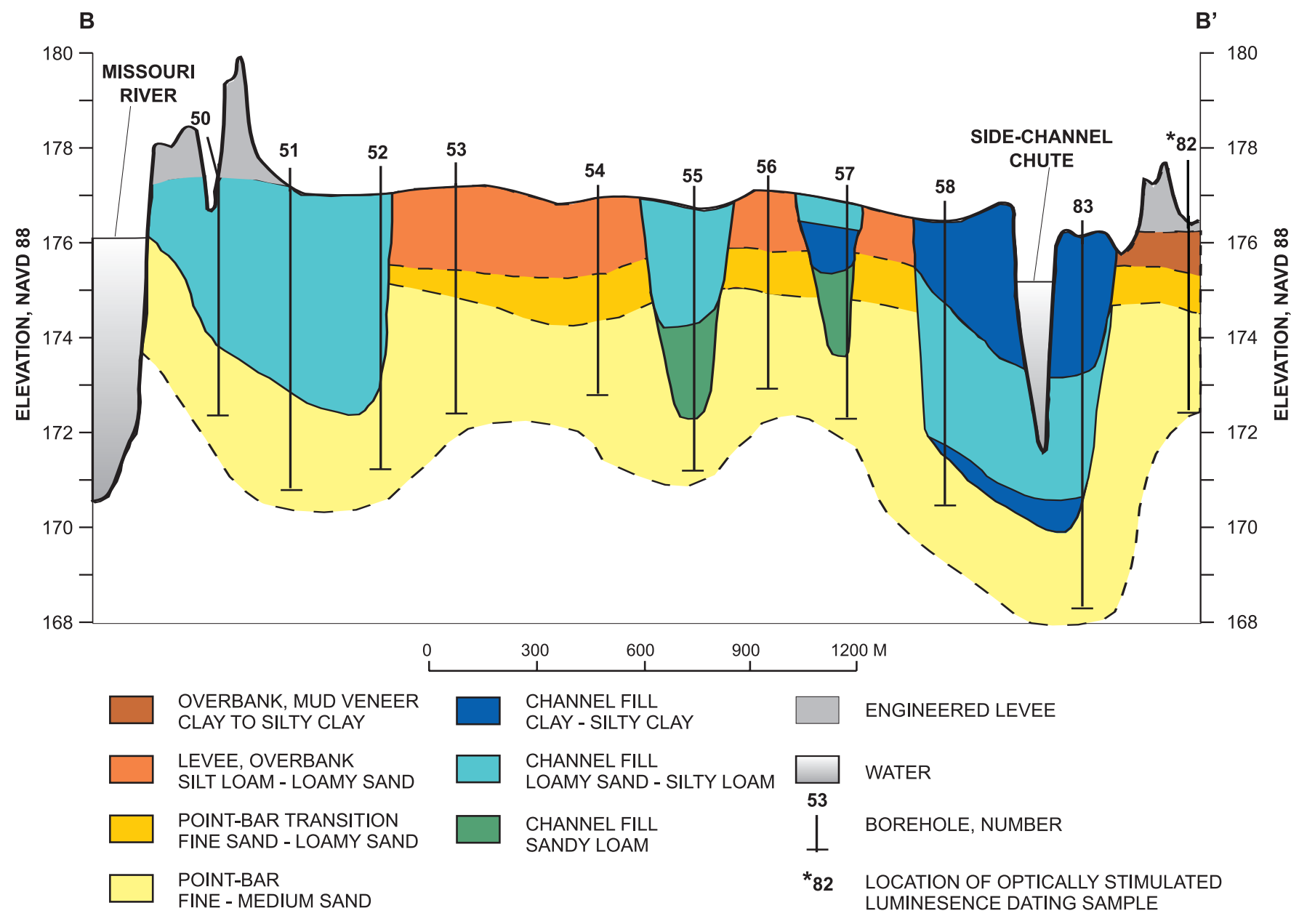

Figure 6. The cross section B-B' indicates channel-fill, point-bar, and meander-loop allounits mapped, and the grain-size and depositional environments which comprise these allounits. 


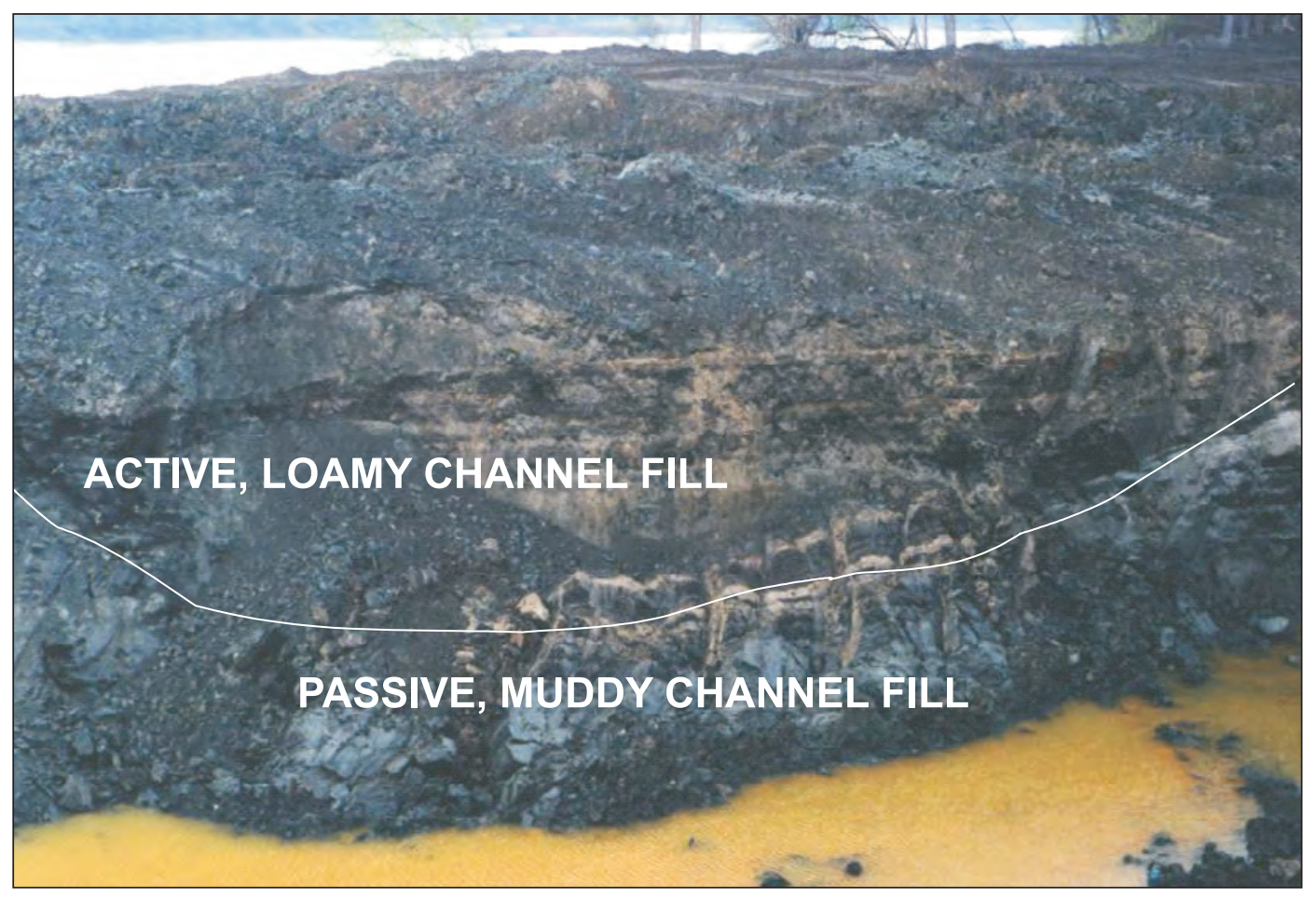

Figure 7. Cross section of a typical channel fill. This cross section was cut at the west end of the excavated chute channel and records the channel drilled in boreholes 50 and 51, cross section B-B'. Height of the bank is about $4 \mathrm{~m}$.

main channels. The system in the Overton area would thus not be a true island-braided system, but would better be characterized as a meandering system with abundant islands developed by side-channel chute initiation. This multi-channel form persisted up to historical documentation in the 1800's (fig. 1). Flood-plain strata upstream near Carrollton, Missouri reveal a similar multi-channel form at that location that dates back to about $1.5 \mathrm{ka}$ (Holbrook and others, 2005). However, older surficial alluvial deposits near Carrollton reveal varying dominance of a single-thread channel form prior to $1.5 \mathrm{ka}$. Whether the river near Overton Bottoms had a single-thread pattern prior to $1.5 \mathrm{ka}$ as well cannot be resolved because previous alluvial deposits have been eroded.

Point-bar units at Overton Bottoms North fine upward from fine-to-medium, clean, cross-bedded sand to loamy fine sand, and are covered in most places by a thin veneer of clay to silty clay of variable thickness (typically $<1.5 \mathrm{~m}$ ). The sandy part of the fining-upward succession records active bar growth on the inside channel bend during channel migration (fig. 8). The silty interval at the top of the point-bar deposits sits directly atop this point-bar succession and records levee and overbank deposition coeval with point-bar growth. The mud veneers which cover these deposits in cross section A-A' were deposited later during overbank flooding events. It appears that the younger, mostly historical-age strata in B-B' have not experienced the extent of overbank flooding recorded by the layer of mud veneer above silty levee deposits in A-A'. This likely reflects the younger age and shorter flood history of point-bar deposits in B-B'.

The stippled unit labeled as splay sand on top of A-A' conforms with topographic expression of a large splay form, and overlaps with areas of known sand-splay deposition that resulted from the 1993 flood. Cross section boreholes did not reveal distinct contacts of sand units on overbank fines, however. This observation suggests that episodically deposited splay sand has probably been mixed with underlying fine sediment in overbank and channel-fill deposits by deep agricultural plowing.

\section{Implications of Surficial Mapping for Environmental Management}

Previous studies have described the surficial alluvium of the Missouri River Valley simply as 6-9 m of fine "top stratum" overlying as much as $25 \mathrm{~m}$ of sandy and gravelly bottom stratum (Emmett and Jeffery 1969; Kelly and Blevins, 1995). Our study served to differentiate units within the surficial alluvium at a finer scale of resolution. The top stratum definition includes channel-fill allounits and the upper levee, overbank, and splay parts of point-bar allounits of this study. The lower 
sandy parts of our point-bar allounits are part of the underlying coarse "bottom stratum," much of which is assumed to be Pleistocene outwash. The coarse and permeable bottom stratum deposits form the alluvial aquifer deposit of the Missouri River Valley.

The thickness of the top stratum is highly variable, and determined by local presence of point-bar or channel-fill allounits. Point bars have much thinner top-stratum caps whereas channel-fill allounits can be as much as $9 \mathrm{~m}$ thick. Where the top stratum forms a sufficient permeability barrier, and the water table impinges on its base, these finer units have the potential to confine the water table.

Areas where this top-stratum is more permeable will be areas where the alluvial aquifer can be recharged directly from the flood-plain surface. Conversely, the ability of the top stratum to slow infiltration will determine the capacity of the flood plain to retain water on the surface. The capacity of the top stratum to inhibit infiltration is largely controlled by its thickness and texture, which is in turn controlled by allounit distribution.

Generally, channel-fill allounits will be better at retaining surface water than point-bar units. Channel fills are thick accumulations of mostly low-permeability deposits; they are thick enough that they are unlikely to develop secondary permeability from desiccation cracks or animal burrows that could connect to the underlying sand deposits. In addition channel fills tend to occur in topographic depressions and have internal bedding that is concave up, thereby increasing their ability to pond water (figs. 5-7).

In comparison, point-bar allounits comprise mostly permeable sand, and have thinner deposits of low-permeability top stratum. Some of these point-bar units are capped by relatively impermeable mud-rich overbank deposits, but others are capped only by silty levee deposits that may not impede infiltration. Thin overbank mud deposits capping point-bar deposits may be breached by desiccation cracks or bioturbation processes, however, and so may not always provide the infiltration barrier expected. Mud drapes can be expected to form on point-bar accretion surfaces during slower flows that follow major flooding events (figs. 2, 8). Such mud drapes, however, will tend to be of local occurrence and their concave down orientation may not provide an effective barrier to infiltration. Point-bar units therefore are areas of enhanced recharge to the alluvial aquifer, especially where the overlying top stratum is thin, and the water table is not at the surface. Such areas do not have high potential for engineered wetlands, and they present opportunities for enhanced contamination of the aquifer in the event of chemical spills.

Because of their topographic position and low permeability, channel-fill allounits have high potential for natural wetlands and would provide good opportunities for construction of engineered wetlands. Channel-fill units tend to occupy low areas on the flood plain inherited from their origin as channels. Thick sections of impermeable deposits within channel fills can slow infiltration sufficiently to support ponding of surface water.

Flood-plain biota can be highly affected by surficial geology and its influences on distributions of water and nutrients. Because sediments in Overton Bottoms are extremely young $(<1.5 \mathrm{ka})$, the texture, $\mathrm{pH}$, and nutrient content of the soil will be strongly determined by the distribution of sediment parent material. Distribution of plants with strong affinities for specific soil conditions may therefore be controlled by the distribution of allounits. Perhaps more important, allounit distribution can have a strong effect on biota distribution through the

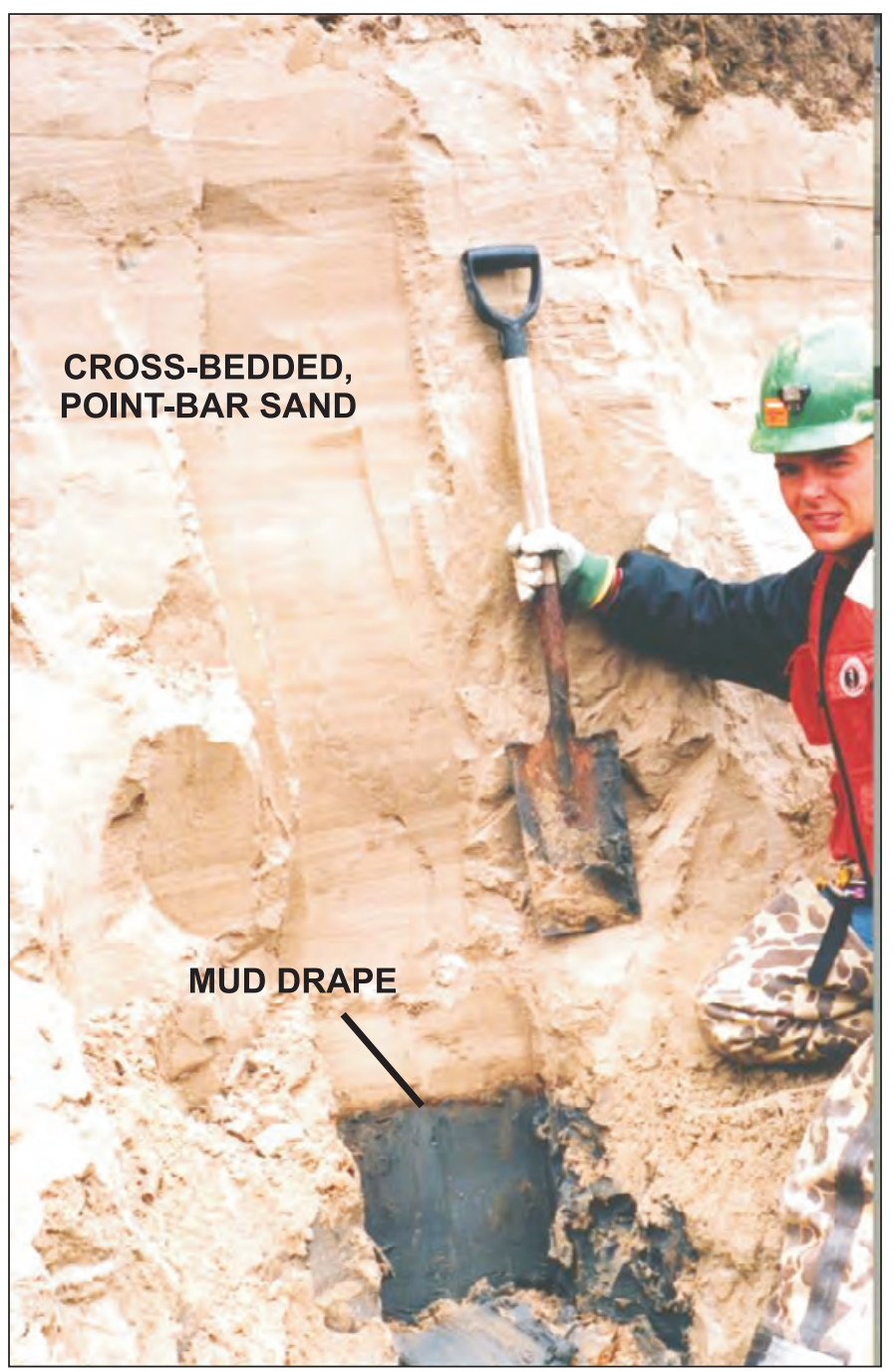

Figure 8. Point bar deposits exposed in excavated chute beneath strata of the channel fill drilled in boreholes 58 and 83 , cross section B-B'. The section is of well sorted, planar crossbedded sand, except for one thick clay drape in the lower part of the section. The location of the picture is approximately where cross section $A-A^{\prime}$ would intersect the excavated chute, if $A-A^{\prime}$ were extended toward the excavated chute. 
effects on surficial water retention (for example, see Faust and others, this volume, chapter 5). Clearly, channel-fill allounits would be expected to retain water and enhance conditions for wetland plant species whereas point-bar allounits would be more conducive to comparatively xeric species. By extension, animals that depend on wetland habitats would also be expected to be associated with channel-fill units. The surficial geology thus strongly defines the mosaic of flood-plain habitat characteristics.

Understanding of surficial geology may also provide improved guidance for design of off-channel aquatic habitat rehabilitation projects. Channel-fill allounits indicate areas where the active river once flowed as a side-channel chute or main channel. As such, they can serve as natural design templates for new channel excavation. A three-dimensional view of channel-fill geometry would also be useful in design to either minimize or maximize ground-water connection. For example, the recently excavated side-channel chute at Overton Bottoms North Unit is excavated locally through the prior channel fill and into an underlying point-bar allounit, thereby potentially enhancing ground-water exchange between the chute and alluvial aquifer. Closer adherence to the thalweg of the old chute could have minimized connection with groundwater if this were desired. Excavation into the easily erodible sand, however, should also enhance widening and channel migration.

\section{References Cited}

Adamiec, G., and Aitken, M., 1998, Dose-rate conversion factors-update: Ancient TL, v. 16, p. 37-50.

Aitken, M. J., 1998, An introduction to optical dating: Oxford, Oxford University Press, 267 p.

Amadi, F., 2004, Factors influencing morphological changes in an alluvial reach of the Missouri River Valley during the late Holocene-implications for river sensitivity to climate change: Cape Girardeau, Mo., Southeast Missouri State University, Masters thesis, $151 \mathrm{p}$.

Bluemle, J.P., 1972, Pleistocene drainage development in North Dakota: Geological Society of America Bulletin, v. 83, p. 2189-2194.

Bretz, J.H., 1965, Geomorphic history of the Ozarks of Missouri: Missouri Geological Survey and Water Resources, 2nd ser., v. 41, 147 p.

Dahl, 1961, Missouri River studies-alluvial morphology and Quaternary history: Iowa State University, dissertation, 248 p.

Dolde, J., Macklin, L., Amadi, F., Pagen, S., and Holbrook, J., in press, Surficial materials geologic map of the Carrollton West 7.5' quadrangle, Missouri: Missouri Division of Geology and Land Survey, Open-File Report, scale 1:24,000.
Emmett, L.F., and Jeffery, H.G., 1969, Reconnaissance of the ground-water resources of the Missouri River alluvium between Jefferson City and Miami, Missouri: U.S. Geological Survey Hydrologic Investigations Atlas HA-340, 1 sheet, scale 1:125,000.

Fisk, H.N., 1944, Geologic investigation of the alluvial valley of the lower Mississippi River: Vicksburg, Miss., U.S. Army Corps of Engineers, 78 p.

Forman, S.L., and Pierson, J., 2002, Late Pleistocene luminescence chronology of loess deposition in the Missouri and Mississippi river valleys, U.S.: Palaeogeography, Palaeoclimatology, Palaeoecology, v. 186, p. 25-46.

Galloway, W.E., 2005, Gulf of Mexico basin depositional record of Cainozoic North American drainage basin evolution, in Blum, M.D., Marriott, S.B., and Leclair, S.F., eds., Fluvial Sedimentology VII. IAS Special Publication 35: Blackwell Scientific Press, p. 409-423.

Grimley, D.A., 2000, Glacial and nonglacial sediment contributions to Wisconsin episode loess in the central United States: Geological Society of America Bulletin, v. 112, p. 1475-1495.

Heim, G.E. Jr., and Howe, W.B., 1963, Pleistocene drainage and depositional history in northeastern Missouri: Transactions of the Kansas Academy of Science, v. 66, p. 378-392.

Holbrook, J., Goble, R., Amadi, F., Nzewunwah, C., and Main, D., 2005, An integrated record for late Holocene climate in the northern U.S. western interior from strata of the Lower Missouri River-evidence for a regional climate shift at 3500 b.p. [abs]: Salt Lake City, Geological Society of America annual meeting, v. 37, p. 122.

Jacobson, R.B., O’Connor, J.E., and Oguchi, T., 2003, Surficial geologic tools in fluvial geomorphology, in Kondolf, G.M. and Piegay, H., eds., Tools in fluvial geomorphology: New York, Wiley Interscience, p. 25-57.

Kelly, B.P., and Blevins, D.W., 1995, Vertical hydraulic conductivity of soil and potentiometric surface of the Missouri River alluvial aquifer at Kansas City, Missouri and Kansas-August 1992 and January 1993: U.S. Geological Survey Open-File Report 95-322, 19 p.

Main, D.J., Holbrook, J., Jobe, Z., Caster, J., and Avdeev, B., 2005, First record of late Pleistocene deposits from the Missouri River Valley, Norborne quadrangle, Missouri [abs.]: Geological Society of America, southwest section annual meeting, San Antonio, Tex., v. 37, p. 34.

McKenney, R., Jacobson, R.B., and Wertheimer, R.C., 1995, Woody vegetation and channel morphogenesis in low-gradient, gravel-bed streams in the Ozarks Region, Missouri and Arkansas: Geomorphology, v. 13, p. 175-198. 
Miall, A.D., 1996, The geology of fluvial deposits: New York, Springer-Verlag, $582 \mathrm{p}$.

Missouri River Commission, 1894, Missouri River Commission survey maps - 1879: Missouri River Commission, scale $1: 63,360$.

Murray, A.S., and Wintle, A.G., 2000, Luminescence dating of quartz using an improved single-aliquot regenerative-dose protocol: Radiation Measurements, v. 32, p. 57-73.

Murray, A.S., and Wintle, A.G., 2003, The single aliquot regenerative dose protocol-potential for improvements in reliability: Radiation Measurements, v. 37, p. 377-381.

North American Commission on Stratigraphic Nomenclature (NACSN), 1983, North American stratigraphic code: American Association of Petroleum Geologists Bulletin, v. 67, p. 841-875.

Nzewunwah, C., 2003, A pilot study of the Missouri River valley fill: Cape Girardeau, Mo., Southeast Missouri State University, Master's thesis, 104 p.

Nzewunwah, C., Tanksley, N., and Holbrook, J., 2004, Surficial material map of the Malta Bend 7.5' quadrangle, Saline County, Missouri: Missouri Division of Geology and Land Survey, Open-File Report, scale 1:24,000.

Prather, B.E., Booth, J.R., Steffens, G.S., and Craig, P.A., 1998, Classification, lithologic calibration, and stratigraphic succession of seismic facies of intraslope basins, deep-water Gulf of Mexico: American Association of Petroleum Geologists Bulletin, v. 82, p. 701-728.

Prescott, J.R., and Hutton, J.T., 1994, Cosmic ray contributions to dose rates for luminescence and ESR dating-large depths and long-term time variations: Radiation Measurements, v. 23, p. 497-500.

Ruhe, R.V., 1983, Depositional environments of late Wisconsin loess in the midcontinent United States, in, Porter, S.C., ed., Late-Quaternary environments of the United States. V.1, the Pleistocene: Minneapolis, Minn., University of Minnesota Press, p. 130-137.

Soil Survey Division Staff, 1993, Soil survey manual-handbook 18: Washington, D.C., U.S. Government Printing Office, $437 \mathrm{p}$. 
This page intentionally blank. 


\section{Hydrologic Interactions Among Rainfall, Side-Channel Chutes, the Missouri River, and Ground Water at Overton Bottoms North, Missouri, 1998-2004}

By Brian P. Kelly

Chapter 3 of

Science to Support Adaptive Habitat Management: Overton Bottoms North Unit, Big Muddy National Fish and Wildlife Refuge, Missouri

In cooperation with the U.S. Fish and Wildlife Service

Scientific Investigations Report 2006-5086 


\section{Contents}

Abstract

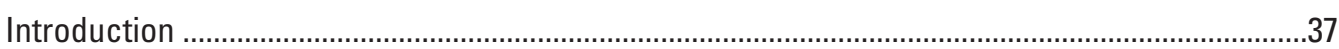

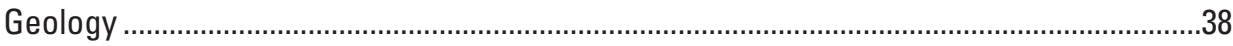

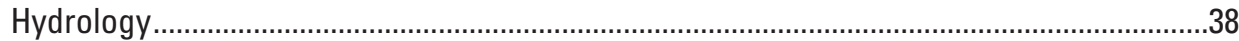

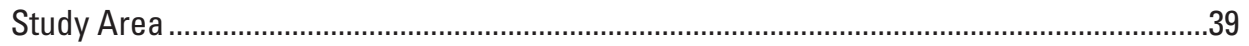

Hydrologic Investigations at Overton Bottoms North .....................................................39

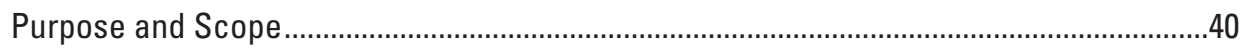

Methods of Hydrologic Data Collection and Analysis ...................................................................

Rainfall, River Altitude, and Ground-Water Altitude ..................................................................4

Potentiometric Surfaces and Depth to Ground Water ..................................................................46

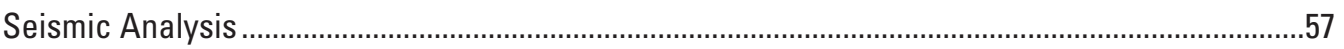

Relations Among Chute Size, River Altitude, and Ground-Water Altitude ......................................60

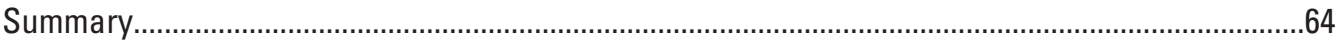

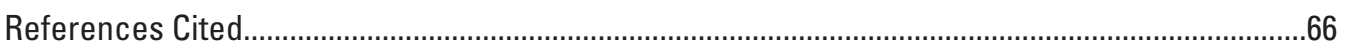

\section{Figures}

1-2. Maps showing-

1. Study area, chute orientations, and well locations at Overton Bottoms North ...... 38

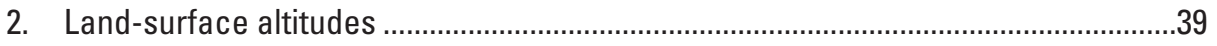

3-4. Graphs showing-

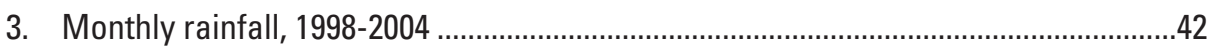

4. Missouri River altitude and ground-water level measurement, 1998-2004..............43

5-6. Hydrographs showing-

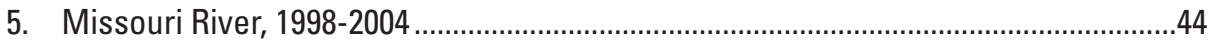

6. Missouri River altitude and chute inlet and outlet altitudes, 2001-2004...................45

7-15. Maps showing potentiometric contours from-

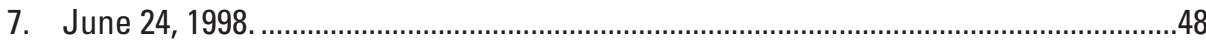

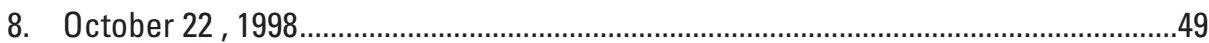

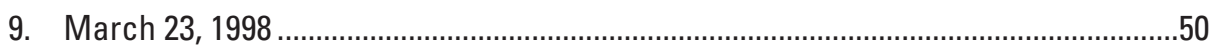

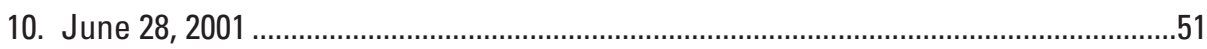

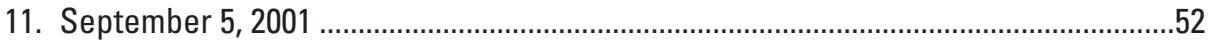

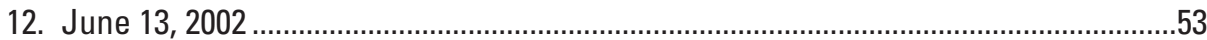

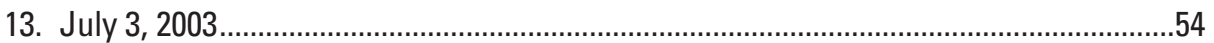

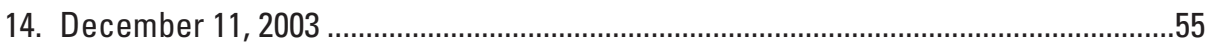

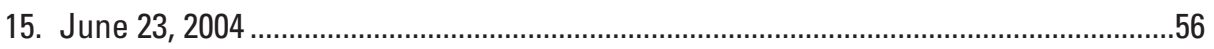

16. Location map of seismic refraction sites, April 9, 2004 ..................................................58

17-19. Graphs showing-

17. Interpreted seismic sections and velocities of sound, April 9, 2004 .......................59

18. The difference between measured ground-water altitude and river altitude .........62

19. Chute and ground-water altitude for wells 1,4 , and 5 ...........................................65 


\section{Tables}

1. Well depths and summary of water-level measurement frequency ……........................41

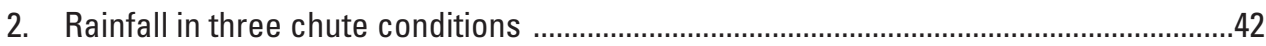

3. Compressional velocity of sound in common Earth materials .........................................57

4. Comparison of seismic-velocity-interface and water-level data, April 9, 2004 ..............60

5. Change in media difference between ground-water and river altitude ..........................61 
This page intentionally blank. 


\title{
Chapter 3 \\ Hydrologic Interactions Among Rainfall, Side-Channel Chutes, the Missouri River, and Ground Water at Overton Bottoms North, Missouri, 1998-2004
}

\author{
By Brian P. Kelly
}

\section{Abstract}

In 2000, the U.S. Army Corps of Engineers (USACE) constructed a side-channel chute at Overton Bottoms North, near Overton, Missouri, to provide shallow water habitat in the Missouri River for native fish. The U.S. Geological Survey collected hydrologic data between 1998 and 2000 before chute construction; between 2001 and 2002 after construction of the first-generation chute; and between 2003 and 2004 after construction of a wider and deeper second-generation chute.

Rainfall during the study had little effect on ground water altitudes. Water flow in the first-generation chute occurred less frequently than in the second-generation chute. Depth to ground water was least for pre-chute conditions, greater for first-generation-chute conditions, and greatest for second-generation-chute conditions at most wells. Ground-water response depended on topography and distance from the chute or river. The median difference between ground-water and river altitude from pre-chute to second-generation-chute conditions at a low-lying wetland area near the chute increased $0.09 \mathrm{~m}$ (meter), but decreased $-0.61 \mathrm{~m},-0.89 \mathrm{~m}$, and $-0.49 \mathrm{~m}$ at three areas of higher land-surface altitudes, indicating lowering of the ground-water altitude relative to the river.

Chute construction breached the levee at the chute inlet and outlet, allowed more frequent inundation of the area at a lower river stage, allowed more frequent surface recharge to the aquifer from flood inundation in low-lying areas, added another river channel in the study area more inland from the main river channel, decreased the difference between groundwater and river altitude from pre-chute to second-generationchute conditions, increased the effect of river altitude changes on ground-water altitude, and increased ground-water altitude variability. During low river stages, lack of inundation and a lower ground-water altitude will decrease water available to wetlands. During high river stages more frequent flooding and recharge of the aquifer through the chute banks will increase water available to wetlands. Therefore, chute construction at Overton Bottoms North will make wetlands drier during low river stage and wetter during high river stage.

\section{Introduction}

Historically, the Lower Missouri River flood plain contained oxbow lakes, seasonally flooded wetlands, and wooded sloughs. These wetlands were continually created and destroyed by the unregulated meandering and flooding of the Missouri River. Channelization and flood-control projects have stabilized and narrowed the river, making the creation of new wetlands rare, thereby reducing flood-plain habitat for fish and wildlife (Funk and Robinson, 1974). In addition, levees and a series of upstream flood-control reservoirs have altered the historic flooding and sedimentation patterns that affect the flood plain.

Recent efforts to mitigate the effects of management of the Lower Missouri River have centered on techniques for reconnecting wetland habitats to the main channel. The techniques include purchasing and converting farmland into more-natural ecosystems by a range of engineered and passive approaches. Catastrophic damage resulting from the large magnitude Missouri River flooding of 1993 prompted an acceleration of mitigation activities as more land became available for purchase by conservation agencies. One of these tracts of land acquired is Overton Bottoms North in central Missouri (fig. 1).

The availability and distribution of surface water and ground water are important factors controlling the composition and spatial distribution of restored flora and fauna in the Missouri River flood plain. The frequency, duration, and timing of flooding; amount and timing of precipitation; amount of runoff from local tributaries; amount of ground water lost or gained; evapotranspiration rates; ice thickness; and wetland water depth, exert strong controls on flood-plain and wetland ecosystem functions. These functions include sediment trapping, nutrient removal, flood-water storage, wildlife habitat, vegetative types, ecosystem stability, and water turbidity (Blevins, 2004). The availability of various flood-plain habitats and wetland types affects the use, distribution, and habitat for fish and wildlife. The size, habitat diversity, and proximity to other habitat types affect migratory and resident wildlife use locally and regionally. 


\section{Geology}

The Missouri River flood plain is underlain by alluvial deposits of Quaternary age consisting of clay, silt, sand, gravel, cobbles, and boulders (Holbrook and others, this volume, chapter 2; Kelly and Blevins, 1995). These unconsolidated deposits overlie shale, limestone, and sandstone bedrock and form the alluvial aquifer. The nature and extent of the alluvial deposits have been greatly affected by numerous changes in discharge, sediment load, and river course during the Quaternary. The present course of the Missouri River in Missouri approximates the southernmost limit of continental glaciation.

Numerous investigations have presented lithologic cross sections showing a 6- to 9-m silt/clay cap that overlies the thick sand and gravel units in the middle of the alluvium in most parts of the Lower Missouri River flood plain (Emmett and Jeffery, 1968, 1969a, 1969b, 1970; Kelly and Blevins, 1995). The cap of fine sediment (top stratum) in the study area is mostly about $2.5 \mathrm{~m}$ thick, although channel fills of 7-8 m thickness have also been documented (this volume, chapter 2). The top stratum may limit water flow between the land surface and the alluvial aquifer. Typically, a thin layer of sandy gravel, gravel, and boulders is at the base of the Missouri River alluvial aquifer.

\section{Hydrology}

The humid continental climate of the study area is characterized by large variations and sudden changes in temperature and precipitation. The study area receives about $0.94 \mathrm{~m}$ of rainfall per year (Gann and others, 1971). The source of water is important to the ecological function of flood plains and flood-plain wetlands; the four potential sources of water are: direct precipitation, runoff from the surrounding uplands, flooding from the river channel, and ground water. Changes in wetland stage from direct precipitation are typically minimal and are limited by rainfall (Jacobson and Kelly, 2004). Runoff from the surrounding uplands can provide water to wetlands near the base of the river-valley walls where upland streams enter the flood plain or in wetlands located in or near drainage channels. Flooding from the river channel can affect the entire flood plain during infrequent large floods, but is most frequent in flood-plain areas unprotected by levees and nearest the river channel. Fluctuations in river stage cause changes in groundwater levels in the Missouri River alluvium (Kelly, 2001). The movement of ground water into wetlands in response to rising river stage has the greatest effect on wetlands that are deep enough to intersect the water table.
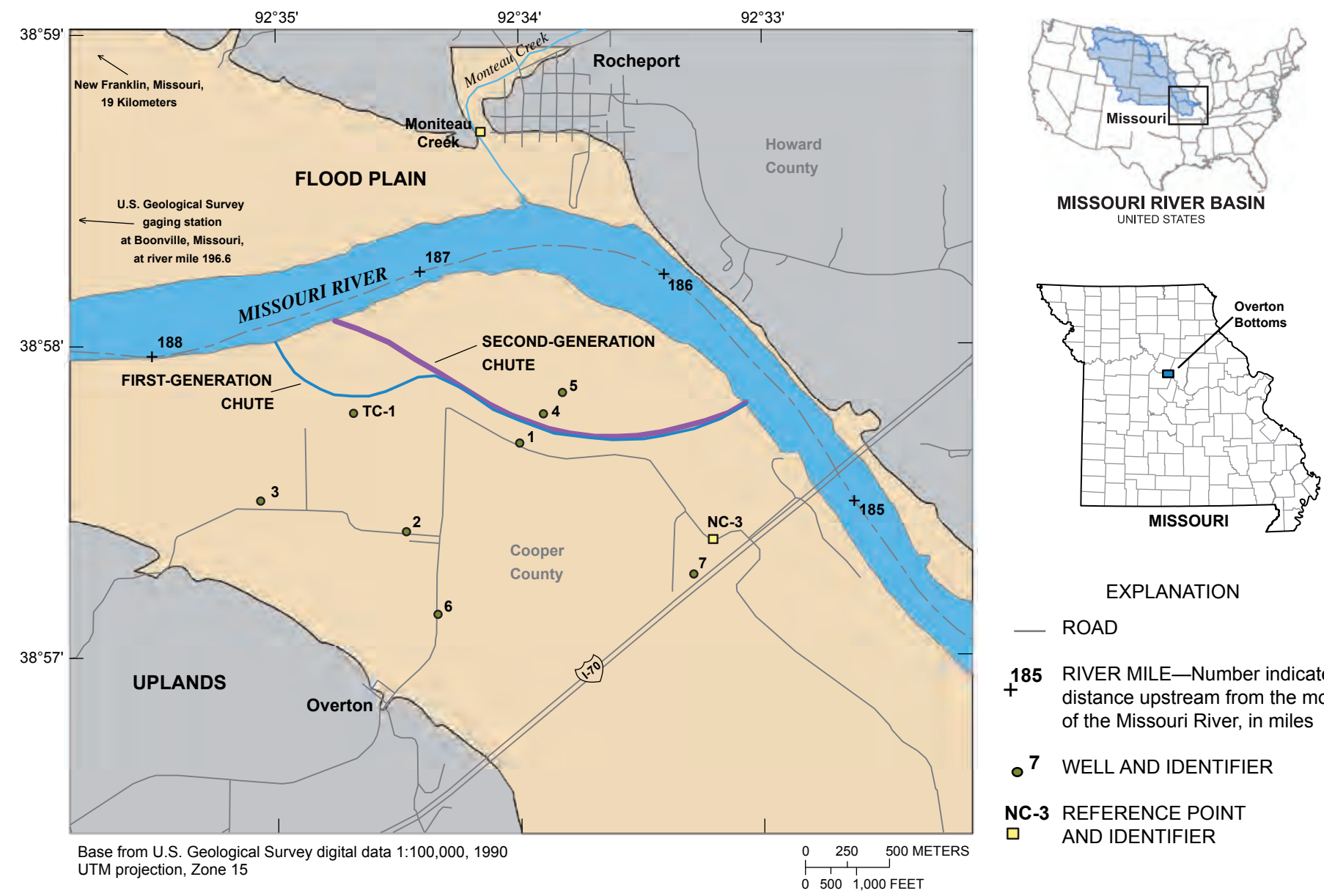

EXPLANATION

- ROAD

$+18$

RIVER MILE-Number indicates distance upstream from the mouth of the Missouri River, in miles

$0^{7}$ WELL AND IDENTIFIER

NC-3 REFERENCE POINT $\square \quad$ AND IDENTIFIER

Figure 1. Study area, chute orientations, and well locations at Overton Bottoms North, Missouri. 


\section{Study Area}

Overton Bottoms is approximately 2,143 ha (hectares) of river bottom along the south bank of the Missouri River in Cooper and Moniteau Counties, Missouri, between river mile 188 and 177. The study area is the upstream portion of Overton Bottoms (Overton Bottoms North) between river mile 188 and 185 (fig. 1). The Overton Bottoms North Unit was purchased as part of the interagency Missouri River Fish and Wildlife Mitigation Project and is administered by the Big Muddy National Fish and Wildlife Refuge, U.S. Fish and Wildlife Service (USFWS; Jacobson, this volume, chapter 1).

The Missouri River alluvial valley has generally subdued topography in the study area (fig. 2); however, highway embankments along Interstate 70 and pre-existing levees are 3-5 $\mathrm{m}$ above the surface of the alluvial valley in some areas. Total relief within the study area is approximately $10 \mathrm{~m}$ with the highest altitude between 182 and $183 \mathrm{~m}$ above North American Vertical Datum of 1988 (NAVD 88) near Interstate 70 and along remaining tops of levees. The lowest altitude on the flood plain (about $173 \mathrm{~m}$ above NAVD 88) is along the south bank of the Missouri River. Low-lying areas collect surface runoff during wet periods causing standing water to remain for some time where soils are poorly drained.

\section{Hydrologic Investigations at Overton Bottoms North}

Hydrologic data have been collected at numerous locations along the Missouri River from the Missouri-Iowa border to St. Louis, Missouri, during recent studies. Previous studies of the hydrology at Overton Bottoms North before and after construction of the side-channel chute (hereafter referred to as the chute) have provided information about the interaction of river stage, wetland stage, ground-water levels, and rainfall at the site (Kelly, 2001).

The USACE began designing a pilot chute at Overton Bottoms North in 1998. The primary design objective was to provide shallow water habitat accessible to native Missouri River fishes (fig. 1). The U.S. Geological Survey (USGS), in cooperation with the USACE, installed three monitoring wells (wells 1, 2, and 3; fig. 1) to provide ground-water level data, and a staff gage in a deep scour hole (NC-3; fig. 1) to provide stage data in support of the design and construction of the first-generation chute. In addition, a reference point located near Rocheport, Missouri, on a bridge over Moniteau Creek near the mouth was used to record Missouri River stage (from backwater on Moniteau Creek) to determine the slope of the Missouri River surface between the Boonville streamflow gage

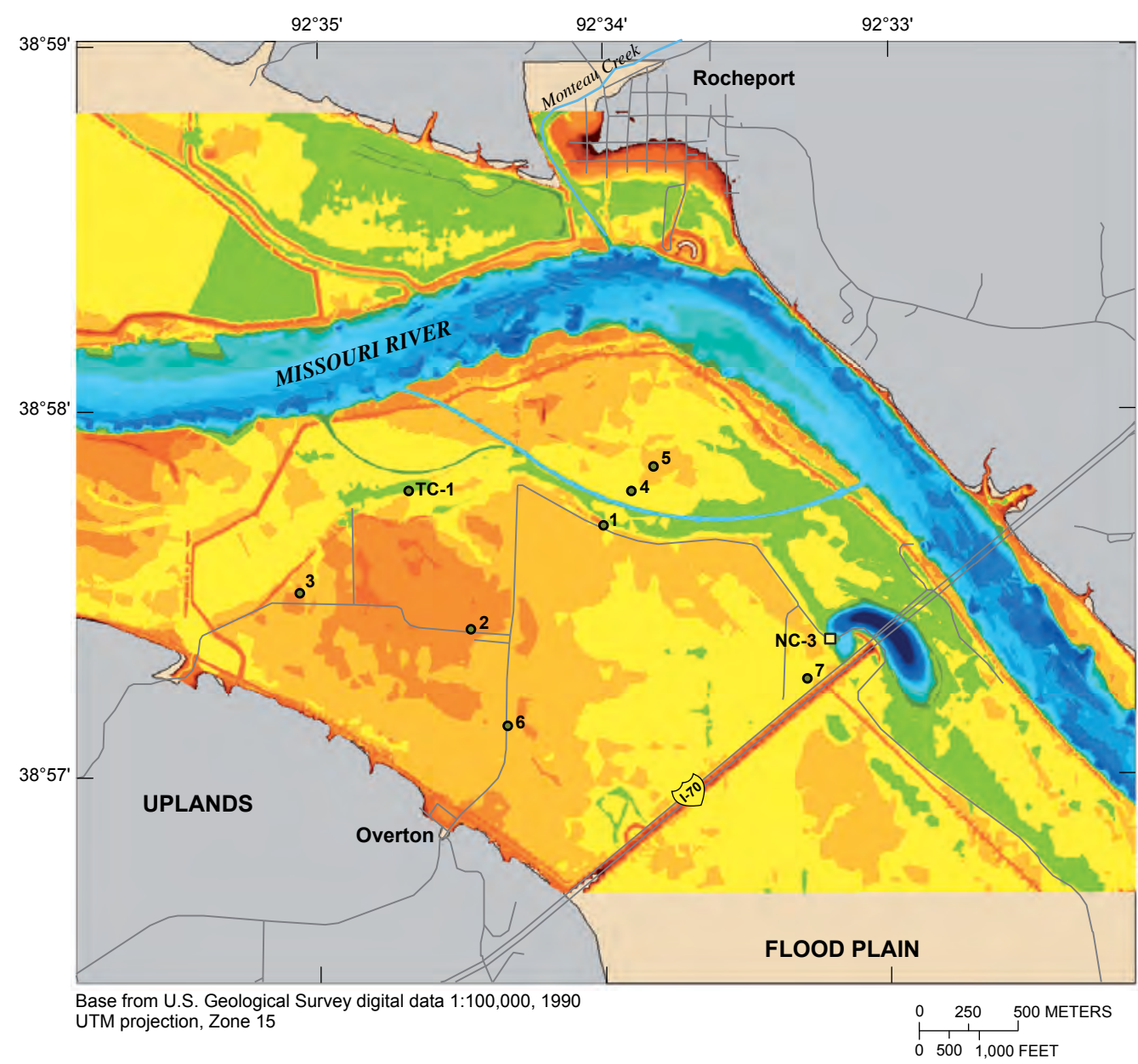

EXPLANATION

LAND-SURFACE ALTITUDE, IN METERS. VERTICAL DATUM IS NAVD 88

\begin{tabular}{|l|l|l|}
\hline & 158.5 to 159 \\
\hline 159.1 to 160 & 171.1 to 172 \\
\hline 160.1 to 161 & 172.1 to 173 \\
\hline 161.1 to 162 & 173.1 to 174 \\
\hline 162.1 to 163 & 174.1 to 175 \\
\hline 163.1 to 164 & 175.1 to 176 \\
\hline 164.1 to 165 & 176.1 to 177 \\
\hline 165.1 to 166 & 177.1 to 178 \\
\hline 166.1 to 167 & 178.1 to 179 \\
\hline$\square$ & 179.1 to 180 \\
\hline 167.1 to 168 & 180.1 to 181 \\
\hline 168.1 to 169 & 181.1 to 182 \\
\hline$\square$ & 182.1 to 183 \\
\hline 169.1 to 170 & 183.1 to 184
\end{tabular}

- ROAD

○ 7 WELL AND IDENTIFIER

NC-3 REFERENCE POINT $\square \quad$ AND IDENTIFIER

Figure 2. Land-surface altitudes for Overton Bottoms North, Missouri. 
(USGS stream-gaging station number 06909000) and Overton Bottoms North (fig. 1). River stage, ground-water levels, and wetland stage data were collected monthly between June 1998 and May 1999 to provide potentiometric surface maps for the area where the new chute was constructed. In 1999, a study by the USGS, in cooperation with the U.S. Environmental Protection Agency (USEPA), evaluated the hydrology of two wetlands (Kelly, 2001). One of the wetlands, TC-1, is located at Overton Bottoms North (fig. 1). River stage, ground-water levels, wetland stage, and rainfall were measured hourly at both wetland sites between June 1999 and July 2000 to characterize the spatial and temporal relations among river stage, ground-water levels, wetland stage, and rainfall. Well TC-1 was installed at Overton Bottoms North for this study. Study results indicated shallow wetlands were most affected by rainfall and flood inundation, whereas deeper wetlands and scours were most affected by ground-water fluctuations caused by river-stage changes below flood stage.

The USACE completed construction of the pilot chute in Spring 2001. This small first-generation chute was approximately 3,000-m long, 12-m wide, and 2-m deep. The inlet design elevation was $174 \mathrm{~m}$, and the outlet design elevation was $172.8 \mathrm{~m}$. Geomorphic evolution of the first-generation chute is documented in Jacobson and others (2004) and this volume, chapter 1 . Water-level recorders were installed in wells TC-1, 1, 2, and 3, and stage recorders were installed in wetland TC- 1 and $\mathrm{NC}-3$ by the USGS, in cooperation with the USFWS to continue hydrologic monitoring at Overton Bottoms North between June 2001 and June 2002 after the first-generation chute was constructed.

In 2003, the USACE modified the first-generation chute by shortening its length and increasing its depth and width to increase the duration of flow in the chute and prevent the accumulation of large woody debris that had blocked the original first-generation chute by 2002 (fig. 1). This second-generation chute is approximately 2,500-m long, 21-m wide, and 6-m deep. The inlet elevation is $170.4 \mathrm{~m}$ and the outlet elevation is $170.8 \mathrm{~m}$. The potential change in hydrology of Overton Bottoms North caused by the large change in chute dimensions provided the impetus to continue assessment of the hydrologic interactions among water levels in the Missouri River, the chute, ground water, and adjacent wetlands.

\section{Purpose and Scope}

The hydrologic assessment at Overton Bottoms North is part of a multidisciplinary USGS effort to link hydrology, geology, and vegetative communities (this volume, chapter 1). The Overton Bottoms North Unit provided an opportunity to evaluate hydrologic effects of this rehabilitation design by comparing hydrologic functions in the flood plain before and after chute construction.

The objectives of the study were to measure and determine the characteristics of and relations among river stage, chute stage, ground-water levels, and rainfall; and to determine whether or not chute construction altered the hydrology at Overton Bottoms North. The purpose of this report is to present the results of this study including river-stage and chutestage data, well hydrographs, potentiometric surface maps, depth to ground-water maps, and hydrologic cross sections for pre-chute, first-generation-chute, and second-generation-chute conditions. The data used were collected from 1998 to 2004.

\section{Methods of Hydrologic Data Collection and Analysis}

Rainfall, chute and river altitude, and ground-water altitude were measured at Overton Bottoms North from June 1998 to May 1999, June 2001 to June 2002, and June 2003 to October 2004. These three periods correspond to pre-chute, first-generation-chute, and second-generation-chute conditions.

Daily rainfall data for the study period were obtained from the National Weather Service site at New Franklin, Missouri, approximately $19 \mathrm{~km}$ (kilometers) upstream from Rocheport, Missouri (fig. 1) (National Oceanic and Atmospheric Administration, 1998, 1999, 2000, 2001, 2002, 2003, 2004). Hourly river stage at Overton Bottoms North was estimated using linear regression between river stages measured to the nearest $0.003 \mathrm{~m}$ at the USGS streamflow-gaging station at Boonville, Missouri (river mile 196.6) and monthly measurements of Missouri River stage at the Overton Bottoms North reference point on Moniteau Creek (Kelly, 2001; fig. 1). Twelve measurements at the reference point were compared to corresponding measurements at Boonville. The coefficient of determination $\left(\mathrm{r}^{2}\right)$ of the linear regression is 0.979 . The 95 percent confidence interval for the estimated altitude is plus or minus $0.003 \mathrm{~m}$. River stage at other locations in the vicinity of Overton Bottoms North was estimated using the regression equation and linear interpolation along the river between the river gage at Boonville, Missouri and the reference point at Moniteau Creek. Chute stage was estimated by linear interpolation of Missouri River stage between the upstream and downstream ends of the chute.

Wells TC-1, 1, 2, and 3 were installed during previous studies. Wells 4 and 5 were installed in March 2003 during the modification of the chute. Wells 6 and 7 were installed after chute modification in August 2003. Pressure transducers and data recorders were installed in wells TC-1, 1, 2, 3, 4, and 5 in July 2003, and in wells 6 and 7 in September 2003. Water levels within wells were measured continually using a vented pressure transducer to 0.009-m accuracy (Global Water Instrumentation, Inc., 2002). Water levels were recorded hourly by a data logger and were checked with monthly manual measurements made using an electric water-level measuring tape to the nearest $0.003 \mathrm{~m}$. All well measuring points were surveyed from a nearby benchmark to 0.003 -m accuracy with respect to NAVD 88. Water levels were converted to altitude above NAVD 88 and reported to 0.003-m accuracy. Well depth and 
summary of water-level measurement frequency are listed in table 1.

Topographic data were obtained from the USACE and were produced from aerial photography (USACE, written commun., 2003). The horizontal datum for this mapping is North American Datum of 1983 (NAD 83). The projection is Universal Transverse Mercator Zone 15. The vertical datum is National Geodetic Vertical Datum of 1929 (NGVD 29), and the units of measurement are feet. The vertical datum was converted to NAVD 88 for this study.

The potentiometric surface is defined by the altitude to which water will rise in a tightly cased well. Potentiometric contour maps were created using well water-level data and surface-water stage data. The potentiometric surface at wells where depth to water was measured was used to estimate the potentiometric surface in distant areas from measured wells, but with similar geologic and topographic characteristics.

Seismic refraction surveys were conducted with a Geometrics Geode Seismic module and a 12 geophone array. Small explosive charges were used to produce the signal source for the surveys. Geophone spacing was 7.5 and $10 \mathrm{~m}$. Because of the short spacing, each survey array is considered a point assessment of seismic stratigraphy. Shot-point locations were surveyed with a hand-held Global Positioning System (GPS) unit. Analysis of seismic-refraction data using the SIPQC V4.0 software package ${ }^{1}$ (Rimrock Geophysics, Inc., 1999) provided thickness and seismic velocities for subsurface layers.

${ }^{1}$ Any use of trade, product, or firm names is for descriptive purposes only and does not imply endorsement by the U.S. Government.

Table 1. Well depths and summary of water-level measurement frequency.

[m, meters; -, no data]

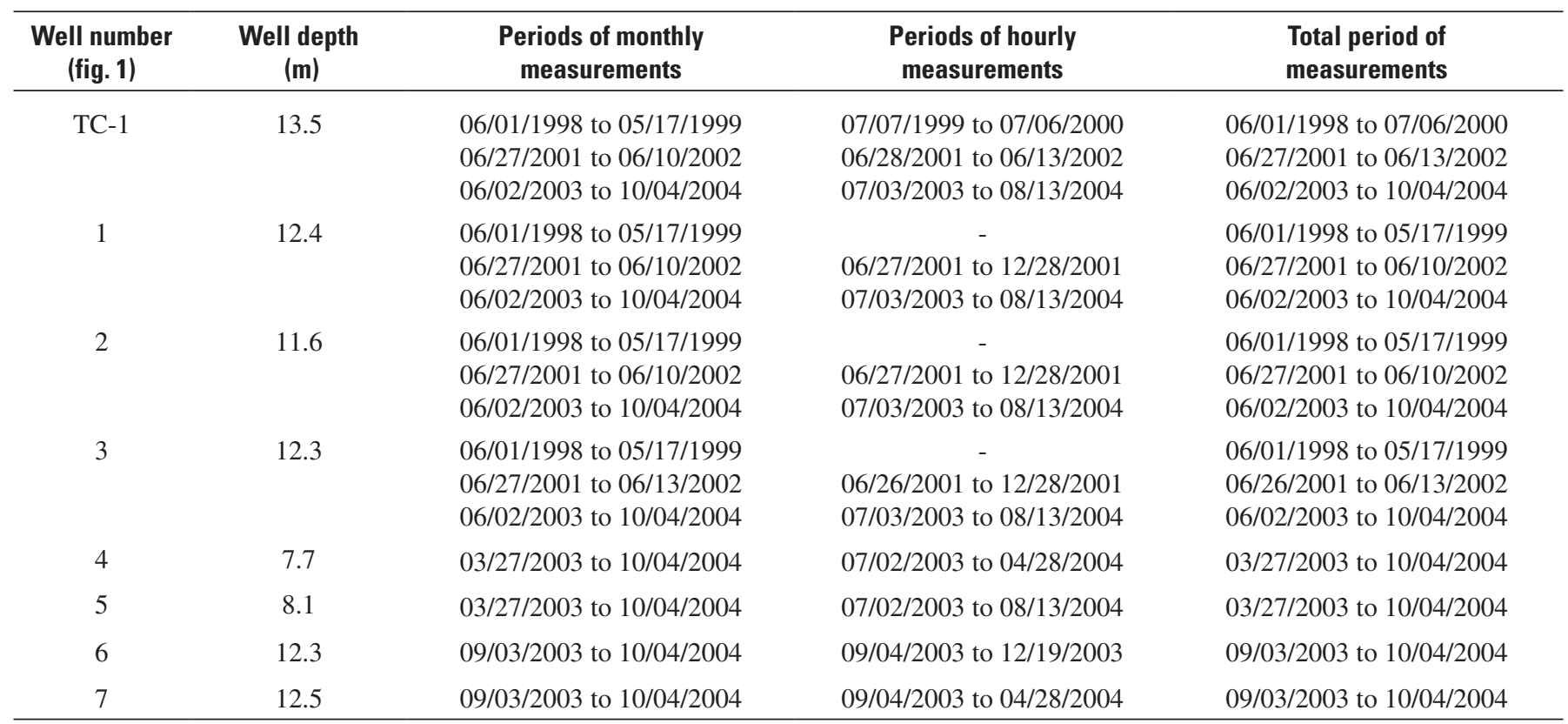




\section{Rainfall, River Altitude, and Ground-Water Altitude}

Monthly rainfall from January 1998 to October 2004 is shown in figure 3. Total rainfall, normal rainfall, and the departure from normal rainfall for pre-chute, first-generationchute, and second-generation-chute conditions are listed in table 2.

The hydrograph for the Missouri River at Overton Bottoms North and monthly ground-water-level measurement dates at Overton Bottoms North are shown in figure 4. Median river altitude was $173.9 \mathrm{~m}$ during pre-chute conditions, 172.2 $\mathrm{m}$ during first-generation-chute conditions, and $171.9 \mathrm{~m}$ during second-generation-chute conditions. Water-level data for the Missouri River and wells TC-1, 1, 2, and 3 for pre-chute, first-generation-chute, and second-generation-chute conditions and water-level data for wells 4, 5, 6, and 7 for secondgeneration-chute conditions are shown in figure 5. All data are digitally stored in the USGS National Water Information System (NWIS) database and are available at http://nwis. waterdata.usgs.gov. For pre-chute, first-generation-chute, and second-generation-chute conditions, when hourly groundwater altitude was recorded, the shape of the well hydrograph is a subdued image of the Missouri River hydrograph as ground-water altitude generally rose and fell with Missouri River altitude. Ground-water altitude for wells TC-1, 1, 2, and 3 consistently was above Missouri River altitude for pre-chute conditions, except when river altitude rose rapidly on June 24, 1998. Ground-water altitude during first-generation-chute conditions, like pre-chute conditions, was normally above river altitude, except when river altitude rose rapidly on September 19, 2001. For second-generation-chute conditions, ground-water altitudes for wells TC-1, 1, 2, and 3 also were above river altitude, except for several periods when river altitude rose rapidly. Ground-water altitudes for wells 4, 5, 6, and 7 were lower than for wells TC-1, 1,2, and 3 for most of the period of measurement during second-generation-chute conditions; however, ground-water altitude for well 6 was less variable with change in river altitude than wells 4,5 , and 7.

Table 2. Total rainfall, normal rainfall, and departure from normal rainfall for pre-chute, first-generation-chute, and secondgeneration-chute conditions.

$[\mathrm{m}$, meters $]$

\begin{tabular}{lccc}
\hline & $\begin{array}{c}\text { Total } \\
\text { rainfall } \\
(\mathbf{m})\end{array}$ & $\begin{array}{c}\text { Normal } \\
\text { rainfall } \\
(\mathbf{m})\end{array}$ & $\begin{array}{c}\text { Departure from } \\
\text { normal rainfall } \\
(\mathbf{m})\end{array}$ \\
\hline $\begin{array}{l}\text { Pre-chute } \\
\text { June 1998 to May 1999 }\end{array}$ & 1.41 & 0.94 & 0.47 \\
$\begin{array}{l}\text { First-generation chute } \\
\text { June 2001 to June 2002 }\end{array}$ & 1.24 & 1.08 & .16 \\
$\begin{array}{l}\text { Second-generation chute } \\
\text { June 2003 to October 2004 }\end{array}$ & 1.57 & 1.46 & .11 \\
\hline
\end{tabular}

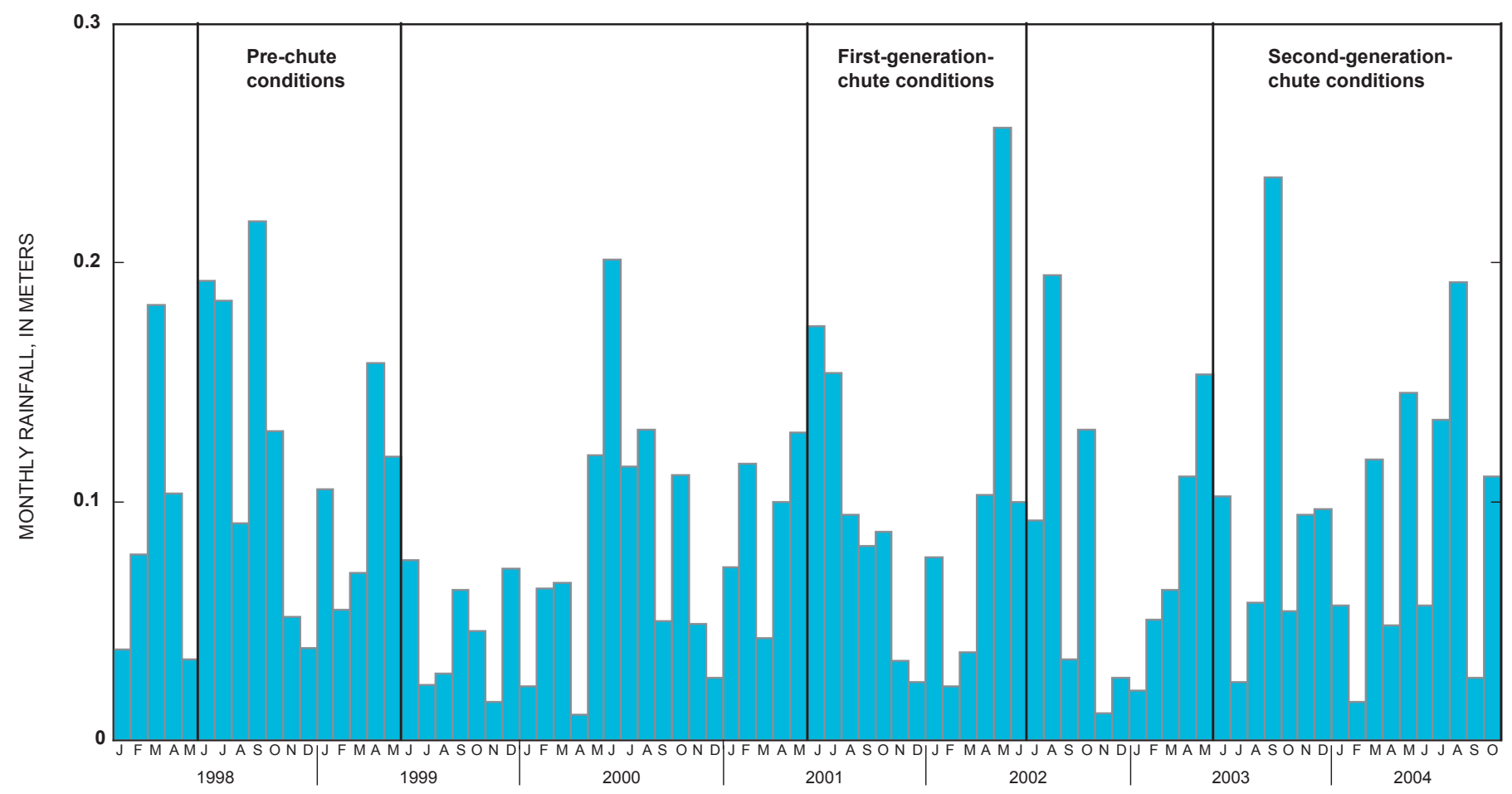

Figure 3. Monthly rainfall during pre-chute, first-generation-chute, and second-generation-chute conditions at or near Overton Bottoms North, Missouri, 1998-2004. 


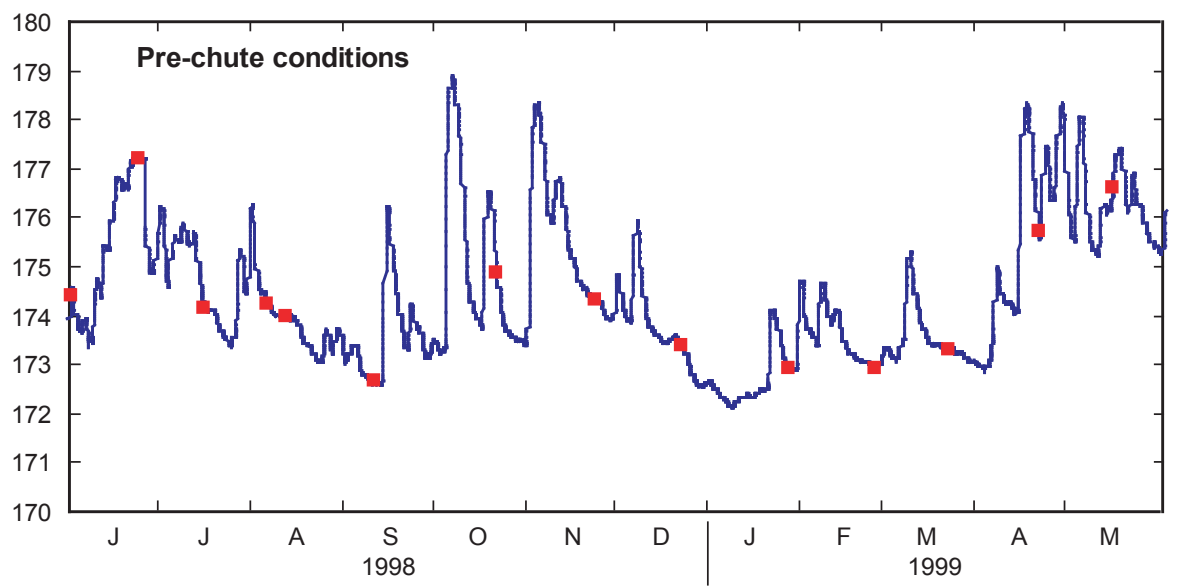

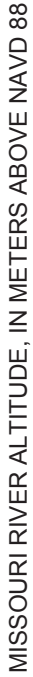
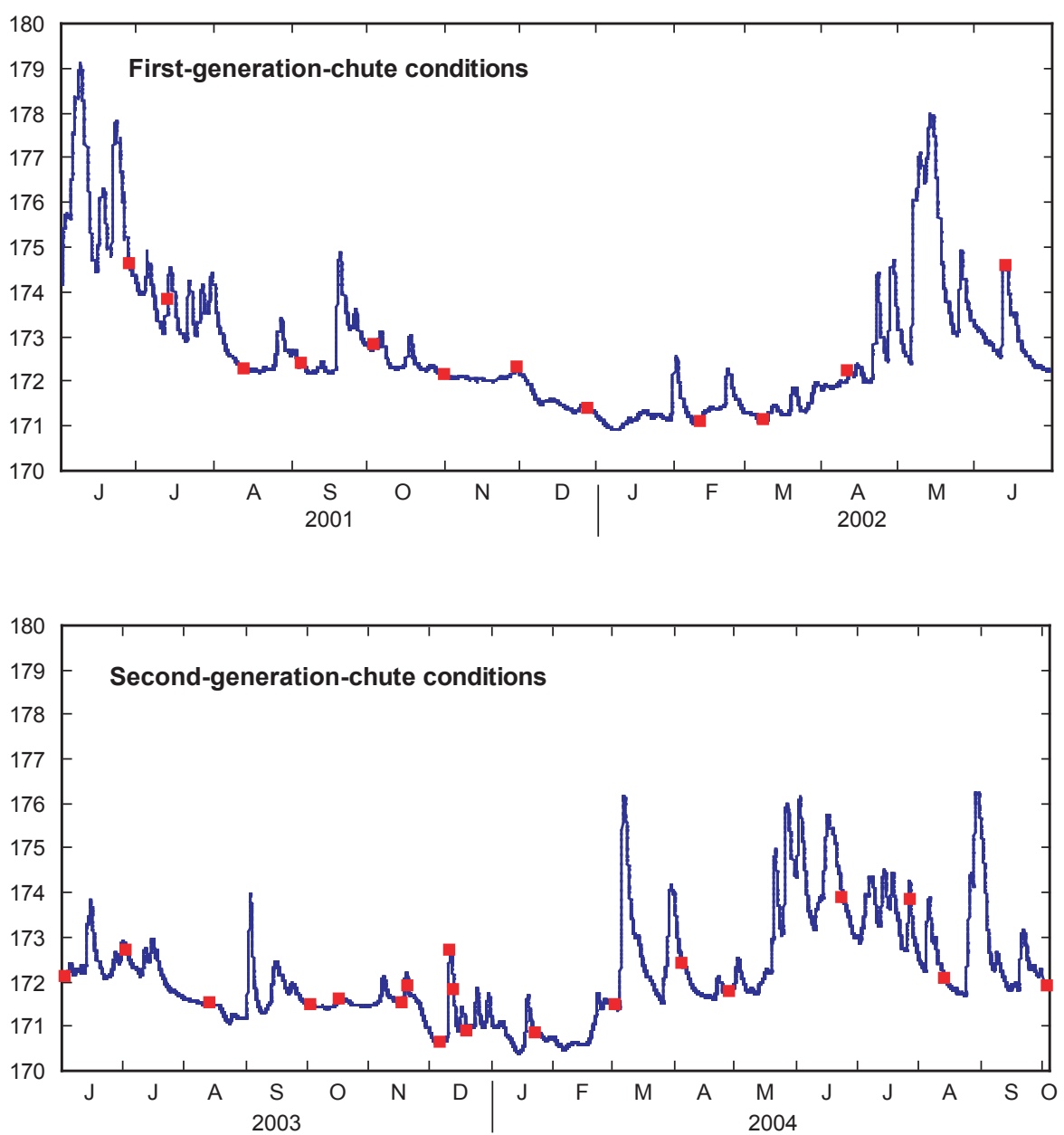

EXPLANATION

MISSOURI RIVER ALTITUDE

- GROUND-WATER LEVEL MEASUREMENT DATE

Figure 4. Missouri River altitude and ground-water level measurement dates for pre-chute, first-generation-chute, and second-generation-chute conditions at Overton Bottoms North, Missouri, 1998-2004. 

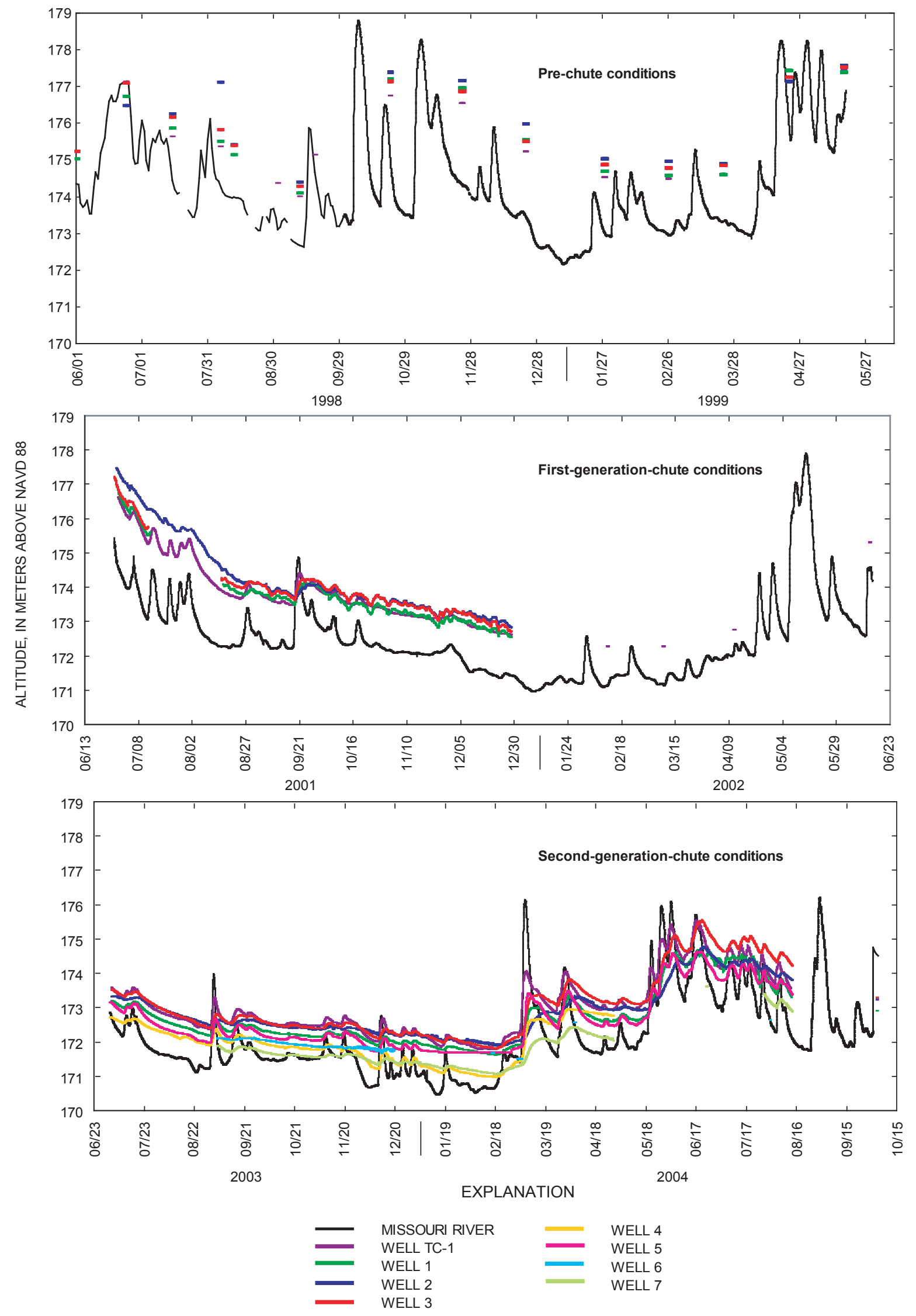

Figure 5. Missouri River at Moniteau Creek with wells for pre-chute, first-generation-chute, and secondgeneration-chute conditions at Overton Bottoms North, 1998-2004. 
Water flowed in the first-generation chute much less frequently than in the second-generation chute. The deeper and wider second-generation chute allows the Missouri River to enter the chute at a lower river stage. During first-generation-chute conditions, water entered the chute only during high Missouri River stage (fig. 6); design specifications were to allow flow into the inlet 30 percent of the time, and into the outlet about 53 percent of the time (Jacobson and others, 2004). The inlet and outlet altitudes of the second-generation chute allows water to flow almost continuously and during second-generation-chute conditions, river stage at the secondgeneration chute inlet always was above the bottom of the chute.
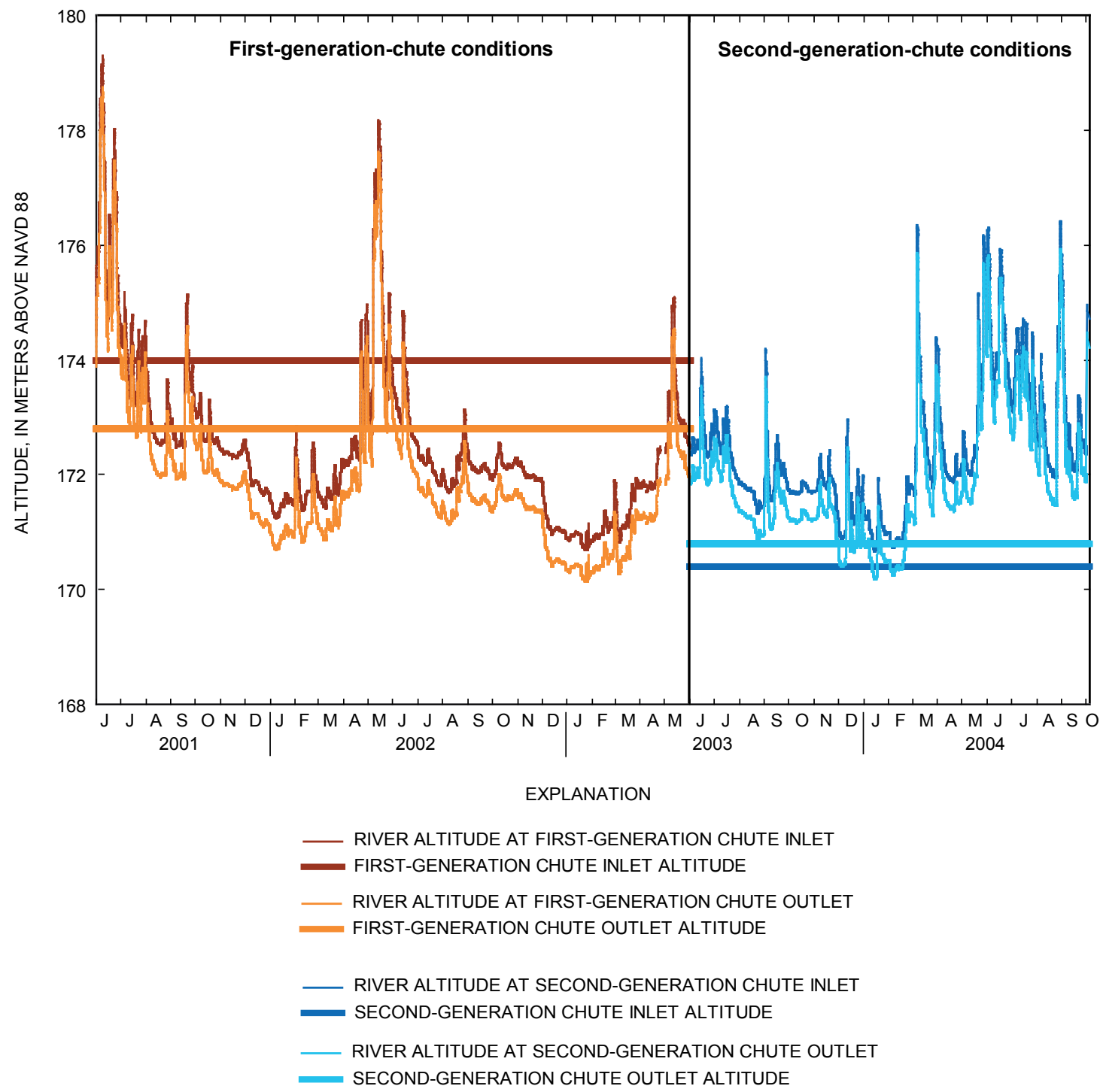

Figure 6. Missouri River altitude and chute inlet and chute outlet altitudes for first-generationchute and second-generation-chute conditions at Overton Bottoms North, Missouri, 2001-2004. 


\section{Potentiometric Surfaces and Depth to Ground Water}

Synoptic ground-water level and surface-water altitude data were used to prepare potentiometric surface maps for pre-chute, first-generation-chute, and second-generation-chute conditions to quantify and characterize changes in the potentiometric surface caused by construction and deepening of the chute. Depth to ground-water maps were constructed by subtracting the altitude of the potentiometric surface from landsurface altitude. The depth to ground water depicted on the depth to ground-water maps was calculated from interpolated potentiometric surfaces. Because there is uncertainty in the creation of a potentiometric surface, there also is uncertainty in the depth to ground-water maps created using potentiometric surfaces; these maps are approximate in nature.

The potentiometric surface and depth to ground water for pre-chute conditions on June 24, 1998, October 22, 1998, and March 23, 1999, are shown in figures 7, 8, and 9. On June 24, 1998, the low-lying areas of Overton Bottoms North, including the area that would become the chute, were inundated (fig. 7); however, had the pre-1993 levee been intact flooding would not have occurred. River altitude increased about $3.5 \mathrm{~m}$ from the first week of June 1998 until June 24, 1998, when the river was at $177.19 \mathrm{~m}$ (fig. 3). Depth to ground water was $3 \mathrm{~m}$ or less for the entire study area and for more than one-half of the study area, depth to ground water was less than $1 \mathrm{~m}$. The highest ground-water altitudes were near the river, and the lowest were near the southwest edge of the flood plain close to Interstate 70 , the farthest distance from the river, indicating recharge to the aquifer from the river. Hydrologic section A-A' (fig. 7) shows the potentiometric surface slightly sloping away from the river.

On October 22, 1998, Missouri River altitude was about $175 \mathrm{~m}$, and a larger part of Overton Bottoms North was inundated (fig. 8). Missouri River altitude was decreasing from a peak of $178.8 \mathrm{~m}$ on October 7, 1998 (fig. 3). Depth to ground water was less than $3 \mathrm{~m}$ for most of Overton Bottoms North, and for more than one-half of the study area, depth to ground water was less than $1 \mathrm{~m}$. The largest depths to ground water were along the bank of the Missouri River, where groundwater altitudes were lowest and land-surface altitude was higher along the remnant levee. The highest ground-water altitude was near the town of Overton, Missouri, and the lowest ground-water altitude was near the Missouri River. Hydrologic section A-A' (fig. 8) shows the potentiometric surface sloped towards the river as river stage was decreasing and water drained from the aquifer into the river.

On March 23, 1999, the ground-water altitudes were substantially less than previous measurements, and less than land-surface altitude for the entire study area (fig. 9). Missouri River altitude decreased from about $175.28 \mathrm{~m}$ on March 10 to $173.32 \mathrm{~m}$ by March 23, but remained stable for the week before ground-water level measurements made on March 23 (fig. 3). Depth to ground water was between 1 and $5 \mathrm{~m}$ for most of the study area, and between 2 and $3 \mathrm{~m}$ for more than one-half of the study area. As of October 22, 1998, the highest ground-water altitudes were near the town of Overton; the lowest were near the Missouri River. The potentiometric surface sloped towards the river along hydrologic section $\mathrm{A}-\mathrm{A}^{\prime}$ as river stage was decreasing and water drained from the aquifer into the river.

The potentiometric surface and depth to ground water for June 28, 2001, September 5, 2001, and June 13, 2002 are shown in figures 10,11 , and 12 for first-generation-chute conditions. On June 28, 2001 (fig. 10), low-lying areas of Overton Bottoms North were still inundated from the Missouri River inundation on June 8, 2001, when the river was $179.02 \mathrm{~m}$ (fig. 3). Depth to ground water was less than $3 \mathrm{~m}$ for most of the study area, and less than $1 \mathrm{~m}$ for more than one-half of the study area. The highest ground-water altitude was located near the town of Overton and, although ground-water level was not measured, a ground-water mound most likely was centered on the island that was created with the construction of the firstgeneration chute. A steep ground-water gradient is indicated by the closely spaced potentiometric contours on both sides and parallel to the first-generation chute compared to the slight gradient between the uplands and well 1. Hydrologic section A-A' (fig. 10) shows the potentiometric surface sloped towards the first-generation chute and the Missouri River as water drained from the aquifer.

On September 5, 2001, the depth to ground water was greater than $3 \mathrm{~m}$ for most of the study area and below the channel bottom of the first-generation chute (172.8 to $174 \mathrm{~m})$ (fig. 11). The altitude of the Missouri River along the Overton Bottoms North reach had decreased from about $173.4 \mathrm{~m}$ on August 27, 2001 to $172.38 \mathrm{~m}$ on September 5, 2001 (fig. 3). Depth to ground water was between 1 and $2 \mathrm{~m}$ below the bottom of the first-generation chute. The highest ground-water altitude was near the town of Overton; the lowest was near the Missouri River. Hydrologic section A-A' (fig. 11) shows the potentiometric surface sloped towards the river as river stage was decreasing and water drained from the aquifer into the river.

On June 13, 2002, the depth to ground water was greater than $1 \mathrm{~m}$ for most of the study area, but was between 0 and $1 \mathrm{~m}$ near the first-generation chute and other low-lying areas near well TC-1. Water was flowing in the first-generation chute (fig. 12). The altitude of the Missouri River had increased from about $172.56 \mathrm{~m}$ on June 11, 2002 to 174.58 m on June 13, 2002 (fig. 3). Highest ground-water altitude was near well 3; the lowest was near the Missouri River. The deflection of the potentiometric contours near the first-generation chute indicates ground water was draining from the aquifer into the chute from both sides. The large space between potentiometric contours indicates a low ground-water gradient. Hydrologic section A-A' (fig. 12) shows the potentiometric 
surface sloped towards the first-generation chute and the Missouri River as water drained from the aquifer, although the slope of the ground-water surface was very slight.

The potentiometric surface and depth to ground water for July 3, 2003, December 11, 2003, and June 23, 2004, are shown in figures 13,14 , and 15 for second-generationchute conditions. On July 3, 2003, the depth to ground water was greater than $3 \mathrm{~m}$ for most of the study area and greater than $4 \mathrm{~m}$ for more than one-half of the study area (fig. 13). The altitude of the Missouri River had decreased from about $173.83 \mathrm{~m}$ on June 15 to $172.69 \mathrm{~m}$ by July 3 (fig. 3). Depth to ground water was less than $3 \mathrm{~m}$ for low-lying areas adjacent to the second-generation chute and well TC-1. Depth to ground water was less than $2 \mathrm{~m}$ along the upstream part of the old channel of the first-generation chute. Highest ground-water altitude was between well 3 and the edge of the flood plain to the southwest. A ground-water mound centered on the island created by the construction of the second-generation chute most likely formed during higher river-altitude conditions of June 2003. Lowest ground-water altitude, adjacent to the Missouri River and the second-generation chute, indicates drainage from the aquifer as river altitude decreased. The large distance between potentiometric contours indicates a low ground-water gradient across the study area. Hydrologic section A-A' (fig. 13) shows the potentiometric surface sloped towards both the Missouri River and the second-generation chute as ground water drained from the aquifer.

On December 11, 2003, after a period of low river altitude, the depth to ground water was greater than $3 \mathrm{~m}$ for almost the entire study area, and greater than $5 \mathrm{~m}$ for more than one-half of the study area (fig. 14). The altitude of the Missouri River slowly had decreased from $172.19 \mathrm{~m}$ on November 19 to $170.68 \mathrm{~m}$ on December 9 then increased rapidly to $172.72 \mathrm{~m}$ on December 11, 2003 (fig. 3). Depth to ground water was between 2 and $3 \mathrm{~m}$ in most low-lying parts of the study area, and less than $2 \mathrm{~m}$ along the upstream part of the old channel of the first-generation chute. Highest ground-water altitude was adjacent to the Missouri River and the second-generation chute as water moved into the aquifer from the river. The two areas of low ground-water altitude were caused by the higher river altitude raising ground-water altitude near the river and the chute. Lowest ground-water altitude was on the south side of the study area near Interstate 70 , and a ground-water depression was centered on the island created by the construction of the second-generation chute. The large distance between potentiometric contours indicates a low ground-water gradient over most of the study area. The steeper gradient near the Missouri River and the second-generation chute indicates rapid recharge to the aquifer was occurring as ground-water altitude adjusted to the rapid change in river stage. Hydrologic section A-A' (fig. 14) shows the potentiometric surface sloped away from the Missouri River and the second-generation chute as surface water recharged the aquifer.

On June 23, 2004, the depth to ground water was less than $4 \mathrm{~m}$ for almost the entire study area, and less than $3 \mathrm{~m}$ for about one-half of the study area (fig. 15). The altitude of the Missouri River increased from $171.81 \mathrm{~m}$ on May 8 to more than $175.71 \mathrm{~m}$ on June 16 , and decreased to $173.81 \mathrm{~m}$ on June 23, 2004 (fig. 3). Depth to ground water was less than $2 \mathrm{~m}$ for low-lying parts of the study area. Highest ground-water altitude was centered near well TC-1, and may indicate focused recharge near the wetland or low permeability resulting in a perched water table. A ground-water mound was centered on the island created by the construction of the second-generation chute most likely formed during higher river-altitude conditions of May 2004. The large distance between potentiometric contours indicates a low ground-water gradient over most of the study area. The steeper ground-water gradient between well 1 and the second-generation chute was caused by the recent decrease in river altitude. Hydrologic section A-A' (fig. 15) shows the potentiometric surface sloped towards the Missouri River and the second-generation chute as ground water drained from the aquifer.

Comparing depth to ground water and potentiometric surfaces for pre-chute, first-generation-chute, and second-generation-chute conditions shows the variability of the surfacewater/ground-water interaction at the study site. Although the effect of chute construction on ground-water flow is shown by the drainage of ground water into the chute, especially during second-generation-chute conditions, the constantly changing river stage, variable rainfall, and rapid response of ground water to these changes illustrate the constantly changing nature of ground-water flow at the study site. 


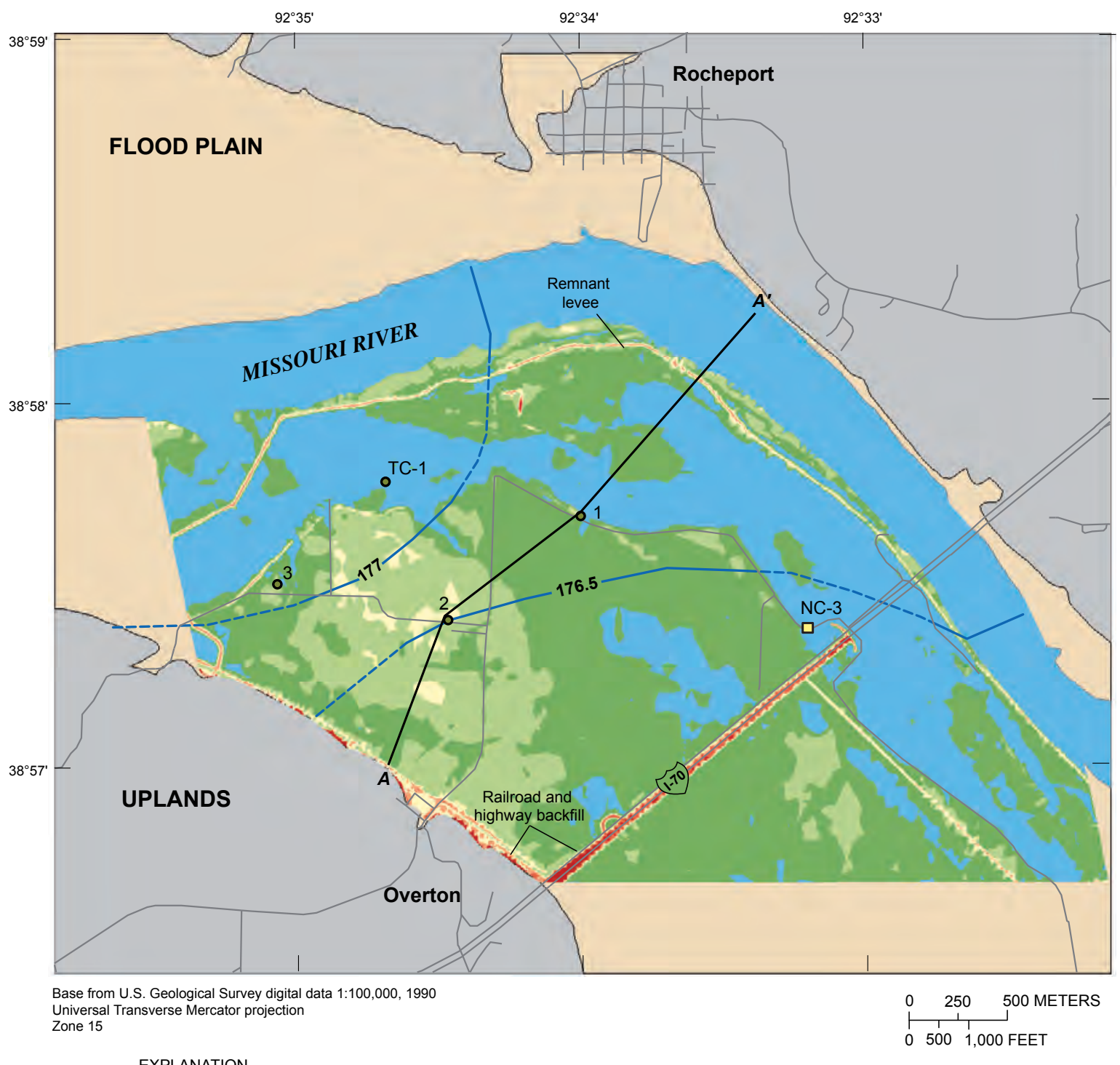

DEPTH TO GROUND WATER, IN METERS

\begin{tabular}{|c|c|}
\hline & Surface water \\
\hline & 0 to 1 \\
\hline & Greater than 1 to 2 \\
\hline & Greater than 2 to 3 \\
\hline & Greater than 3 to 4 \\
\hline & Greater than 4 to 5 \\
\hline & Greater than 5 \\
\hline & ROAD \\
\hline & $\begin{array}{l}\text { POTENTIOMETRIC CONTOUR-Shows } \\
\text { altitude at which water would have stood } \\
\text { in a tightly cased well. Dashed where } \\
\text { approximately located. Contour interval } \\
0.5 \text { meter. Datum is NAVD } 88\end{array}$ \\
\hline
\end{tabular}

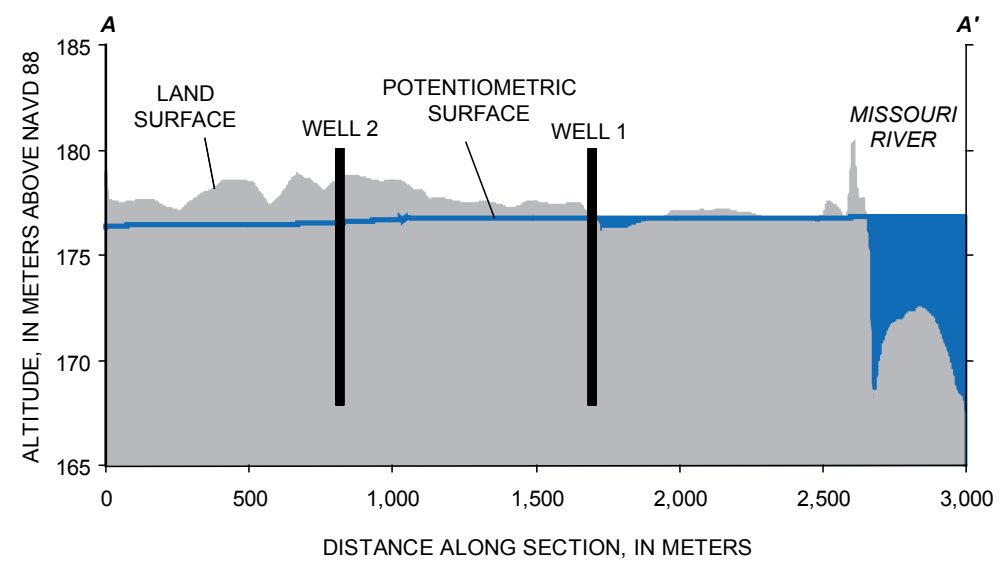

$0^{3}$ WELL AND IDENTIFIER

$\square^{\text {NC-3 }}$ REFERENCE POINT AND IDENTIFIER

Figure 7. Potentiometric contours, depth to ground water, and hydrologic section $\mathrm{A}-\mathrm{A}^{\prime}$ for pre-chute conditions, Overton Bottoms North, Missouri, June 24, 1998. 


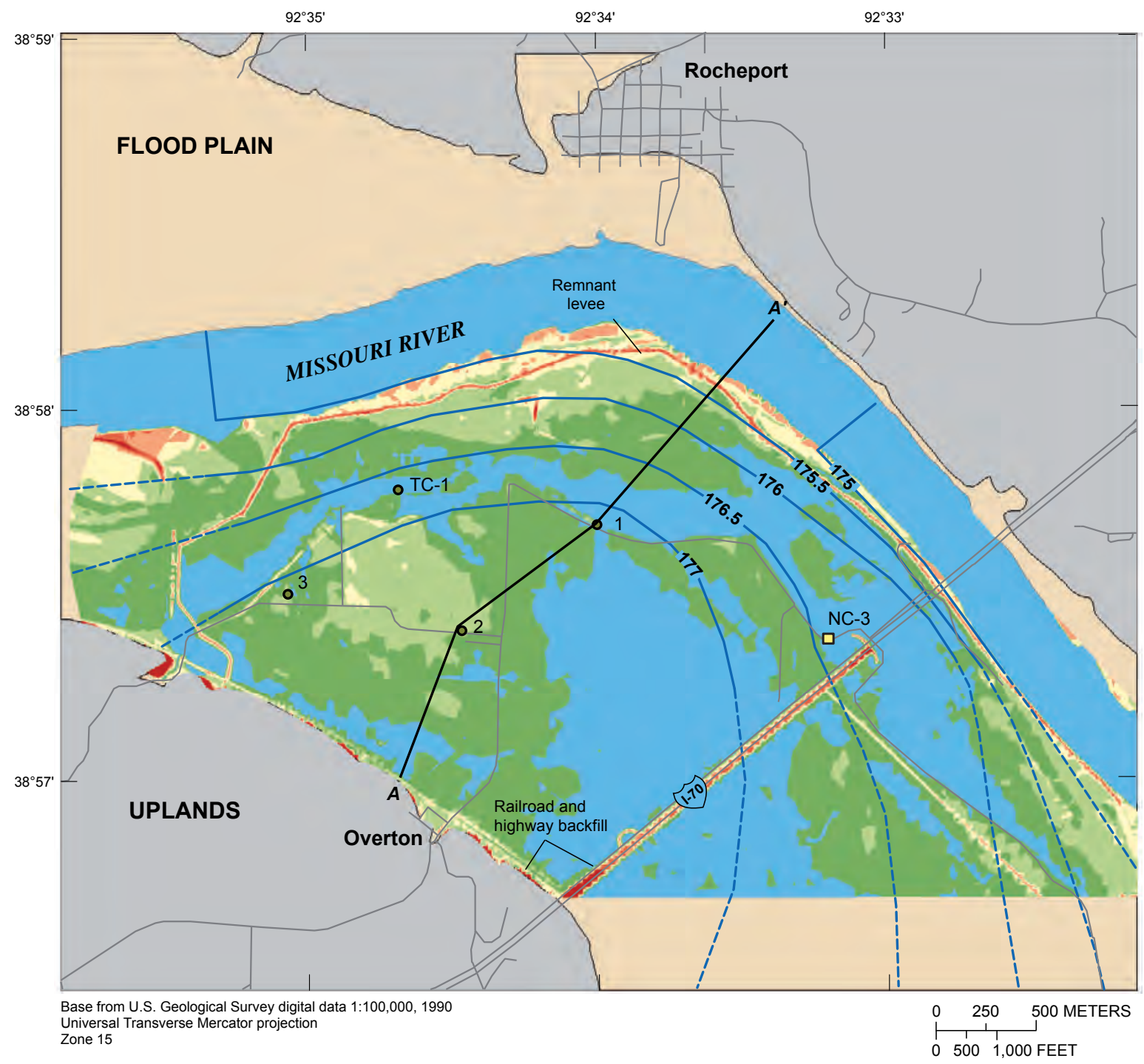

EXPLANATION

DEPTH TO GROUND WATER, IN METERS

Surface water
0 to 1
Greater than 1 to 2
Greater than 2 to 3
Greater than 3 to 4
Greater than 4 to 5
Greater than 5
ROAD
$\square-177$ POTENTIOMETRIC CONTOUR-Shows
altitude at which water would have stood
in a tightly cased well. Dashed where
approximately located. Contour interval
0.5 meter. Datum is NAVD 88

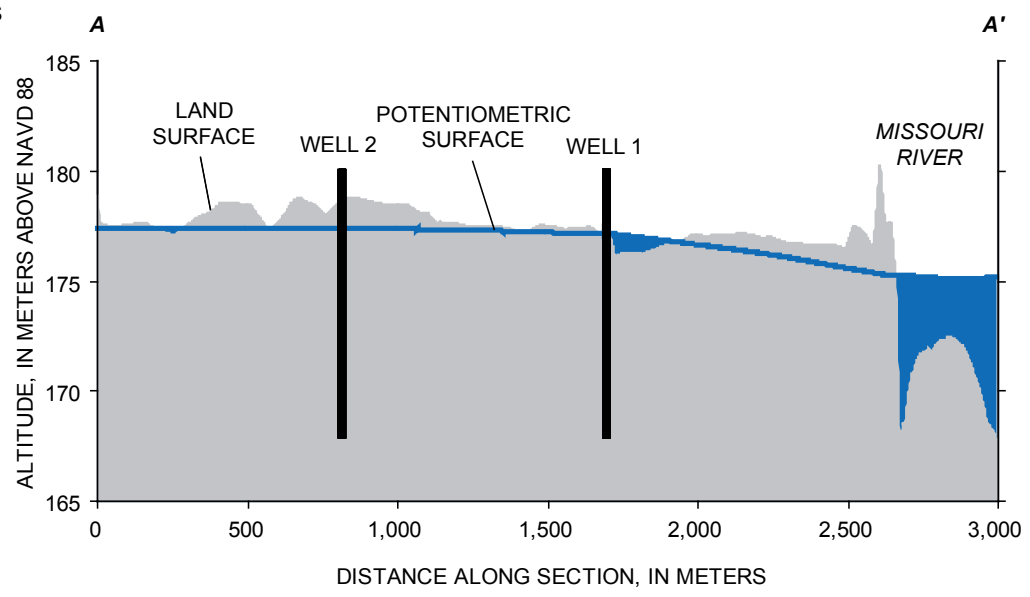

$0^{3}$ WELL AND IDENTIFIER

$\square^{\text {NC-3 REFERENCE POINT AND IDENTIFIER }}$

Figure 8. Potentiometric contours, depth to ground water, and hydrologic section A-A' for pre-chute conditions, Overton Bottoms North, Missouri, October 22, 1998. 


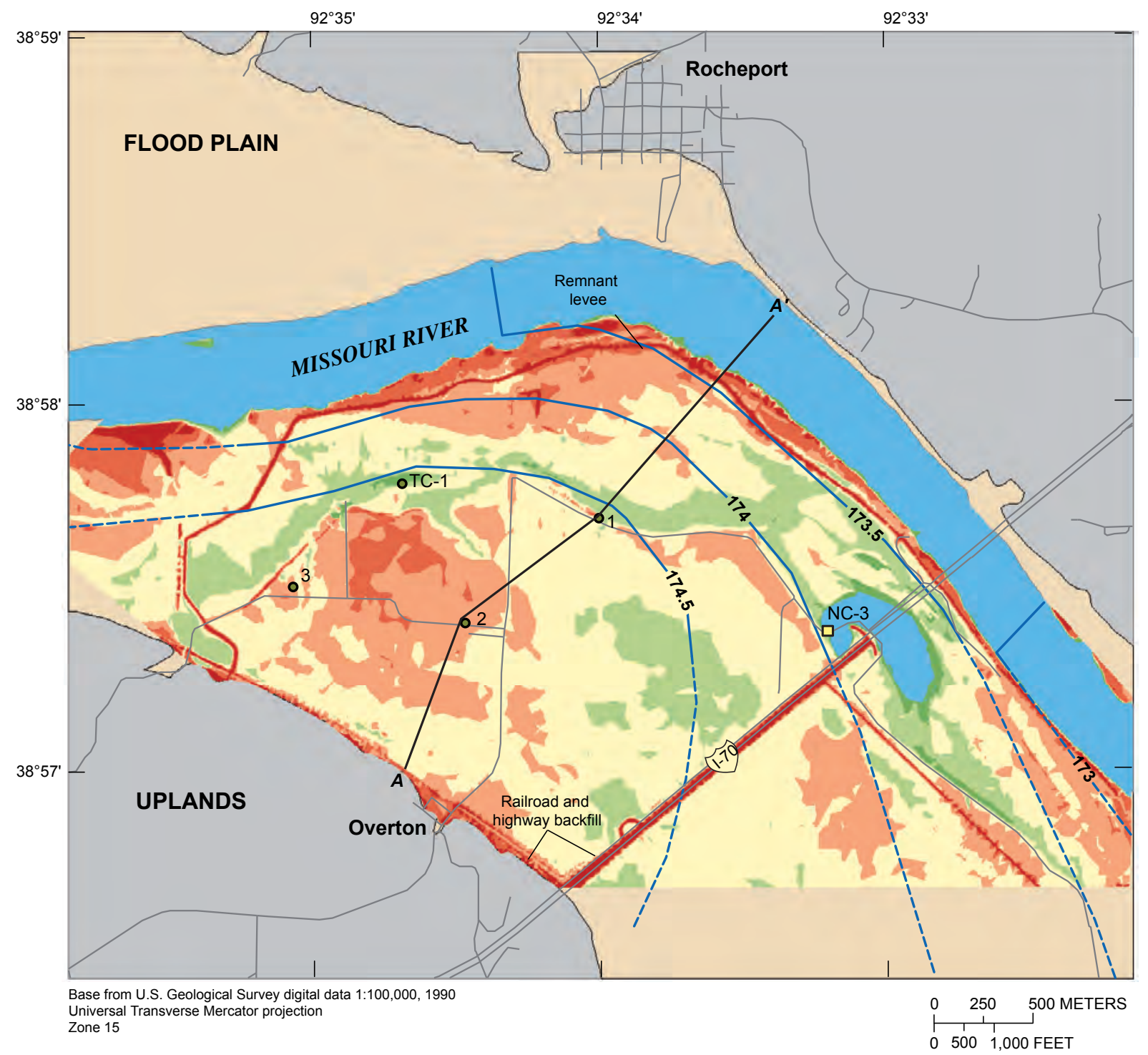

EXPLANATION

DEPTH TO GROUND WATER, IN METERS

Surface wate

0 to 1

Greater than 1 to 2

Greater than 2 to 3

Greater than 3 to 4

Greater than 4 to 5

Greater than 5

ROAD

-174-_ POTENTIOMETRIC CONTOUR-Shows altitude at which water would have stood in a tightly cased well. Dashed where approximately located. Contour interval 0.5 meter. Datum is NAVD 88

$\boldsymbol{A} \longrightarrow \boldsymbol{A}^{\prime}$ TRACE OF SECTION

$0^{3}$ WELL AND IDENTIFIER

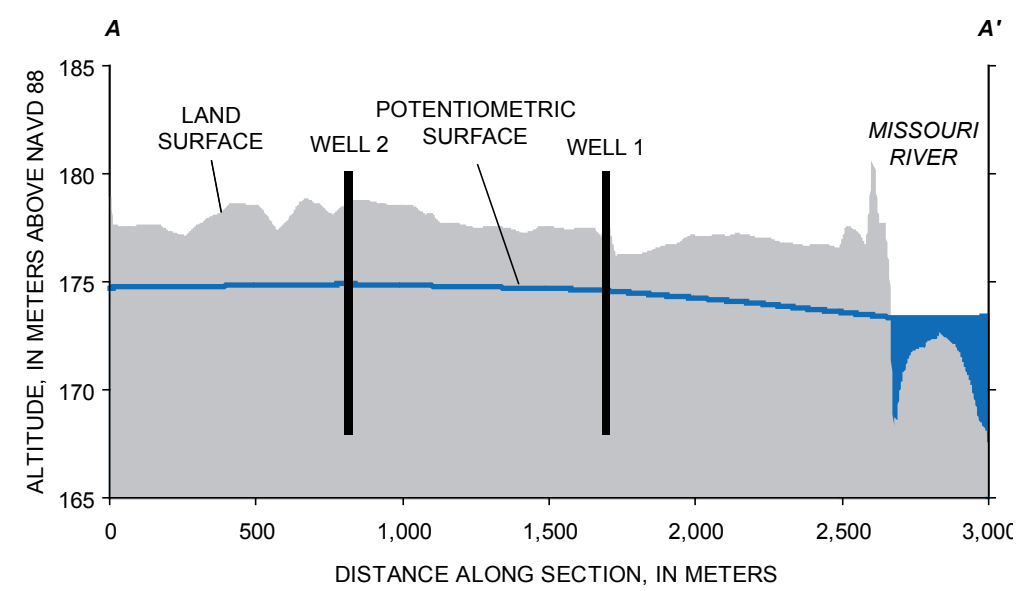

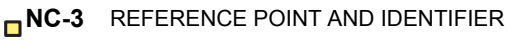

Figure 9. Potentiometric contours, depth to ground water, and hydrologic section $A-A^{\prime}$ for pre-chute conditions, Overton Bottoms North, Missouri, March 23, 1998. 


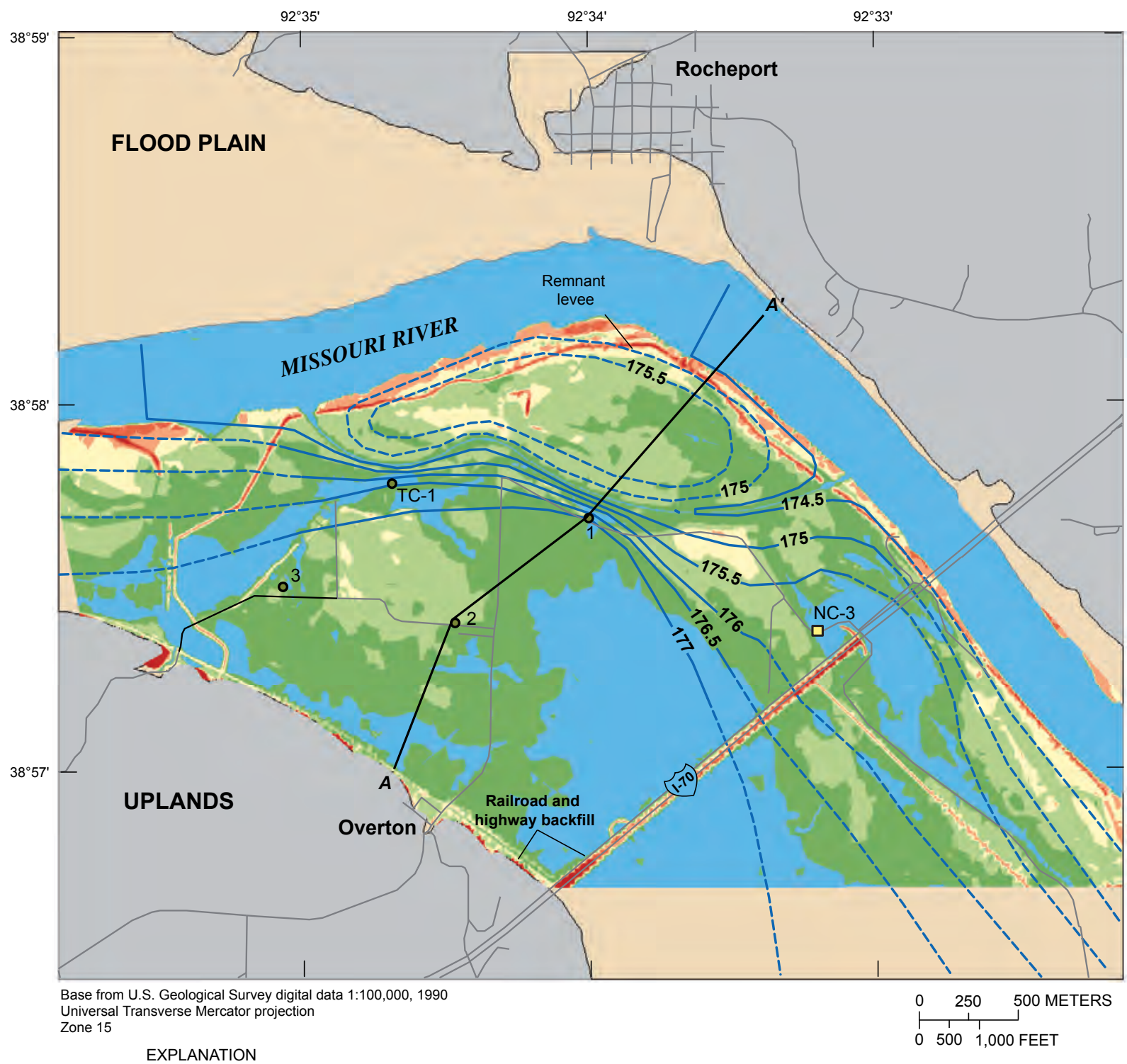

DEPTH TO GROUND WATER, IN METERS

Surface water

0 to 1

Greater than 1 to 2

Greater than 2 to 3

Greater than 3 to 4

Greater than 4 to 5

Greater than 5

ROAD

_177_- POTENTIOMETRIC CONTOUR_Shows altitude at which water would have stood in a tightly cased well. Dashed where approximately located. Contour interval 0.5 meter. Datum is NAVD 88

$\boldsymbol{A} \longrightarrow \boldsymbol{A}^{\prime}$ TRACE OF SECTION

-3 WELL AND IDENTIFIER

$\square^{\text {NC-3 REFERENCE POINT AND IDENTIFIER }}$

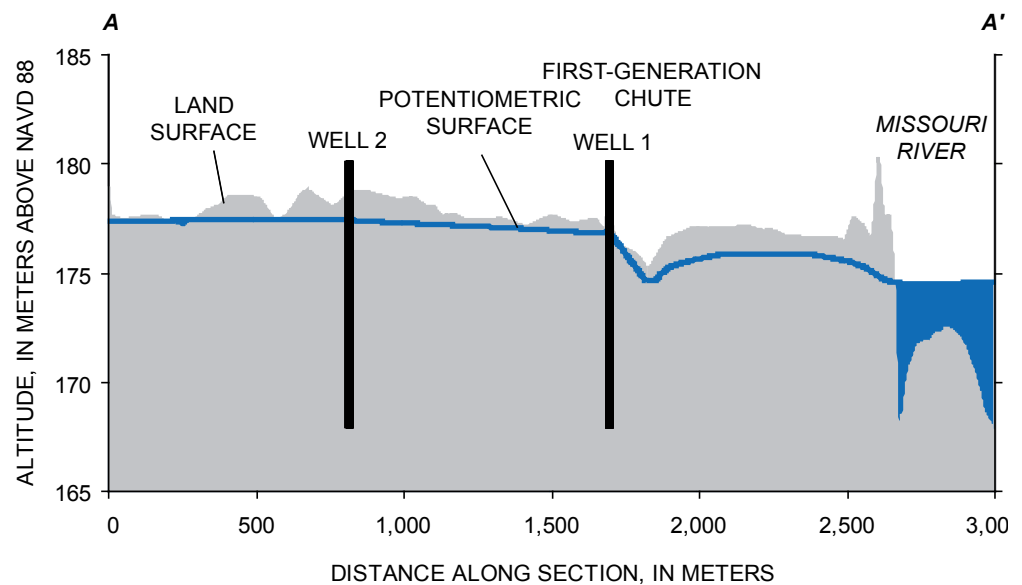

DISTANCE ALONG SECTION, IN METERS

Figure 10. Potentiometric contours, depth to ground water, and hydrologic section $A-A^{\prime}$ for first-generation-chute conditions, Overton Bottoms North, Missouri, June 28, 2001. 


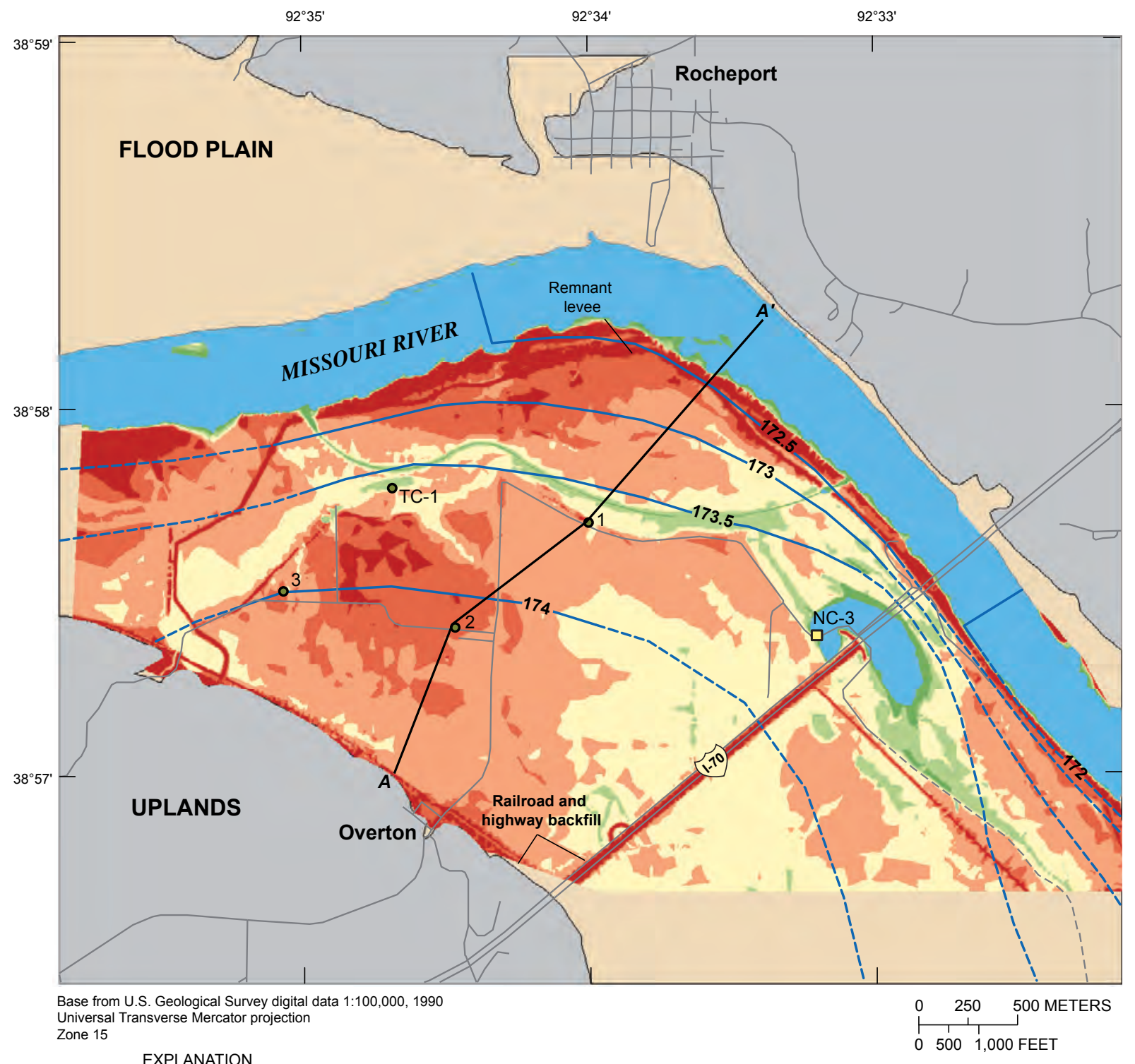

DEPTH TO GROUND WATER, IN METERS

Surface water
0 to 1
Greater than 1 to 2
Greater than 2 to 3
Greater than 3 to 4
Greater than 4 to 5
Greater than 5
ROAD
POTENTIOMETRIC CONTOUR-Shows
altitude at which water would have stood
in a tightly cased well. Dashed where
approximately located. Contour interval
0.5 meter. Datum is NAVD 88

\section{$\boldsymbol{A} \longrightarrow \boldsymbol{A}^{\prime}$ TRACE OF SECTION}

$0^{3}$ WELL AND IDENTIFIER

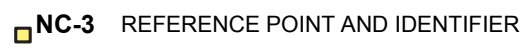

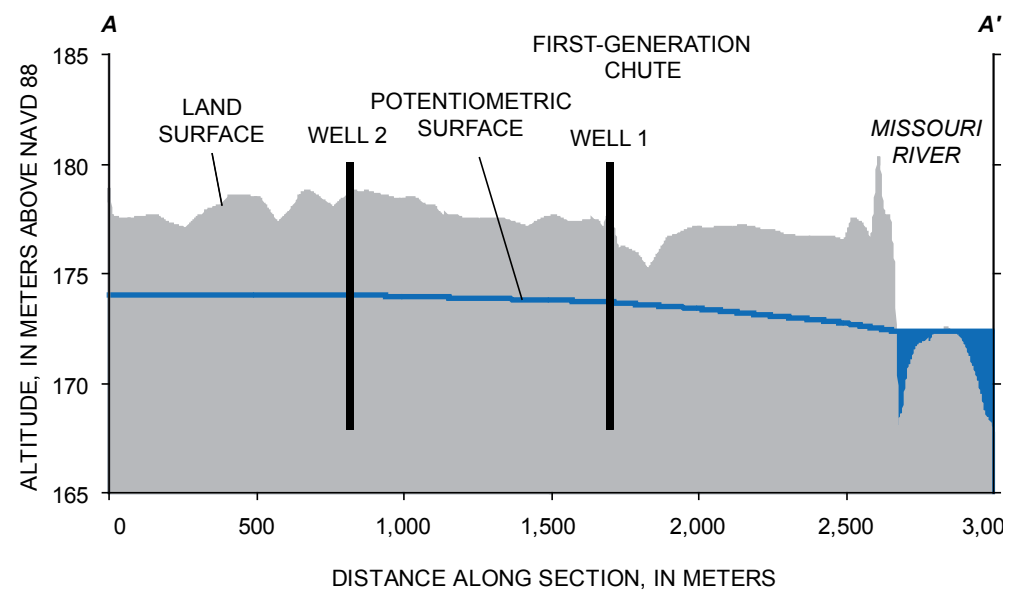

Figure 11. Potentiometric contours, depth to ground water, and hydrologic section $A-A^{\prime}$ for first-generation-chute conditions, Overton Bottoms North, Missouri, September 5, 2001. 


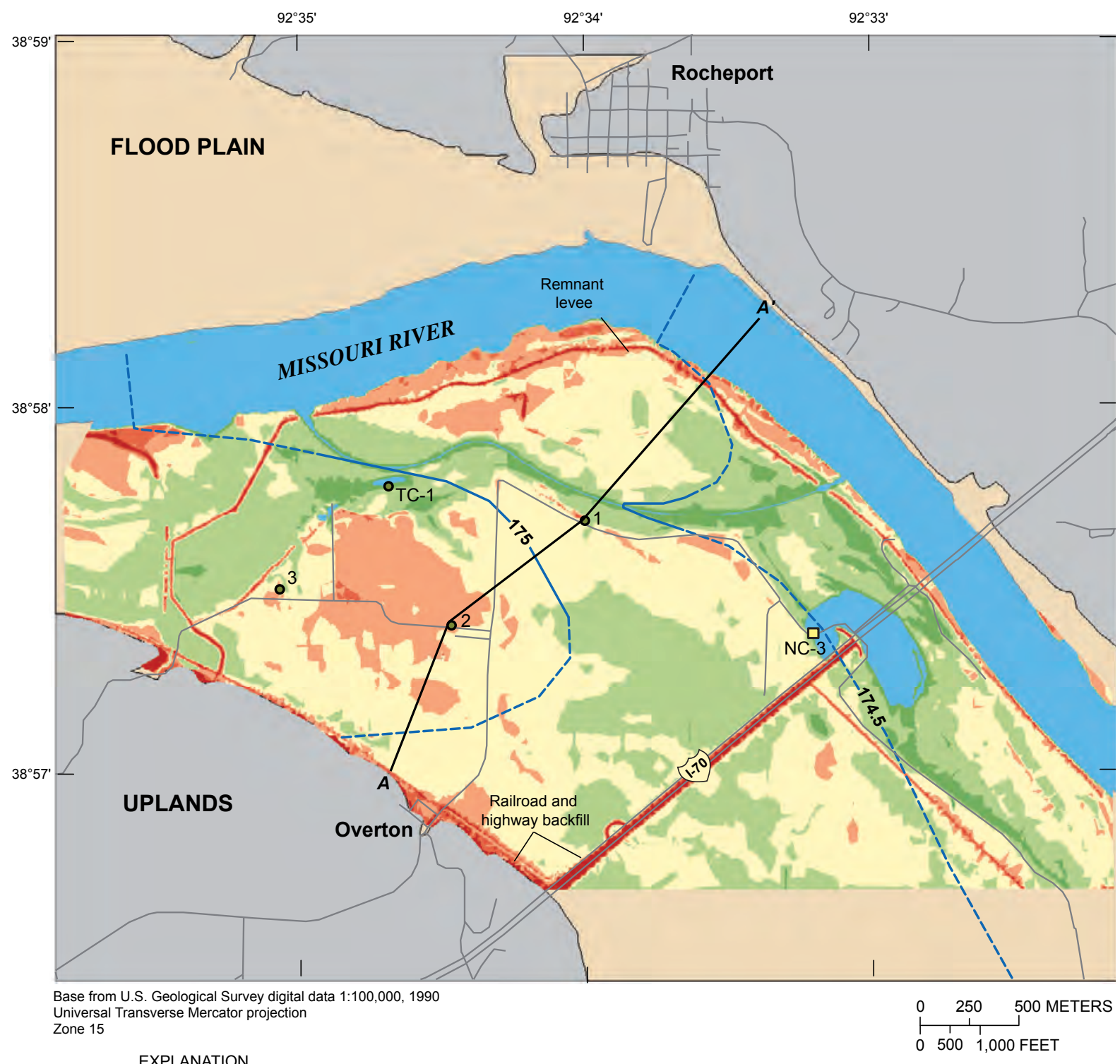

DEPTH TO GROUND WATER, IN METERS

\begin{tabular}{l} 
Surface water \\
0 to 1 \\
Greater than 1 to 2 \\
Greater than 2 to 3 \\
Greater than 3 to 4 \\
Greater than 4 to 5 \\
Greater than 5 \\
\hline $\begin{array}{r}\square \\
\square\end{array}$ \\
ROAD \\
POTENTIOMETRIC CONTOUR-Shows \\
altitude at which water would have stood \\
in a tightly cased well. Dashed where \\
approximately located. Contour interval \\
0.5 meter. Datum is NAVD 88
\end{tabular}

$\boldsymbol{A} \longrightarrow \boldsymbol{A}^{\prime}$ 'TRACE OF SECTION

$0^{3}$ WELL AND IDENTIFIER

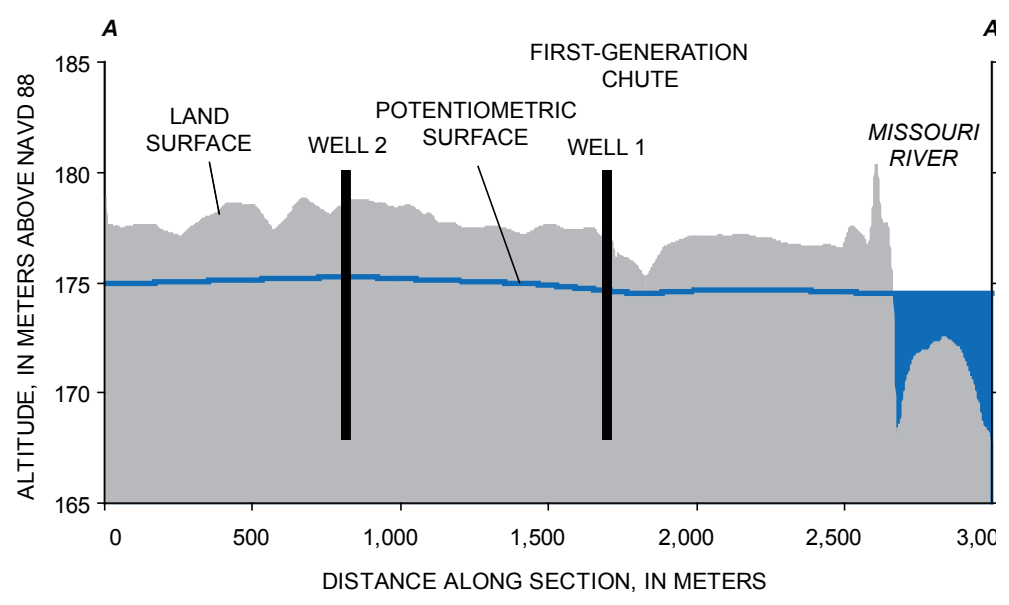

$\square^{\text {NC-3 }}$ REFERENCE POINT AND IDENTIFIER

Figure 12. Potentiometric contours, depth to ground water, and hydrologic section $A-A^{\prime}$ for first-generation-chute conditions, Overton Bottoms North, Missouri, June 13, 2002. 


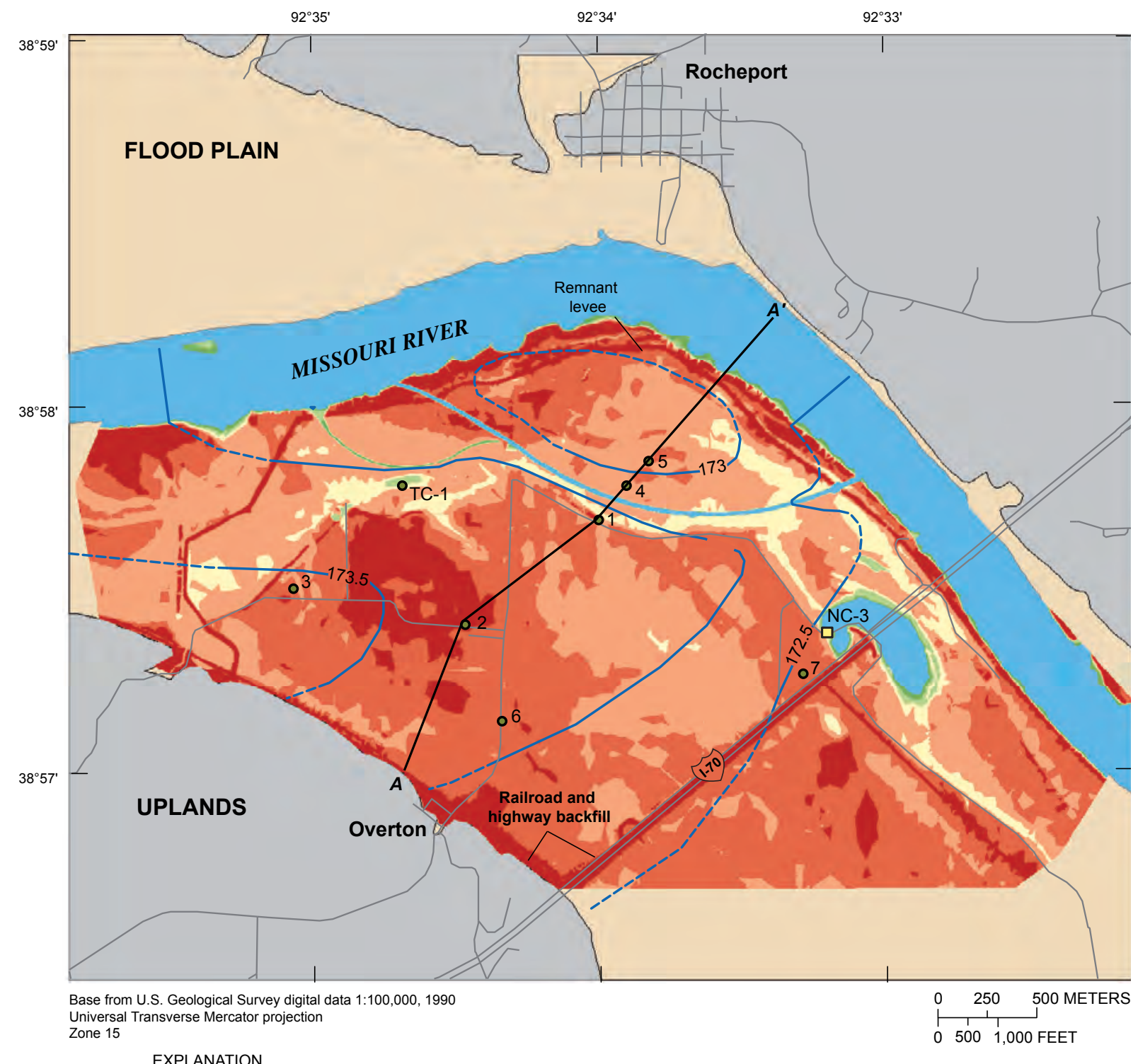

DEPTH TO GROUND WATER, IN METERS

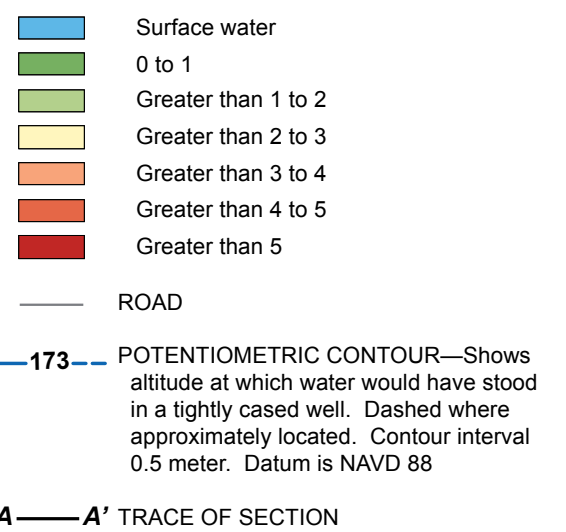

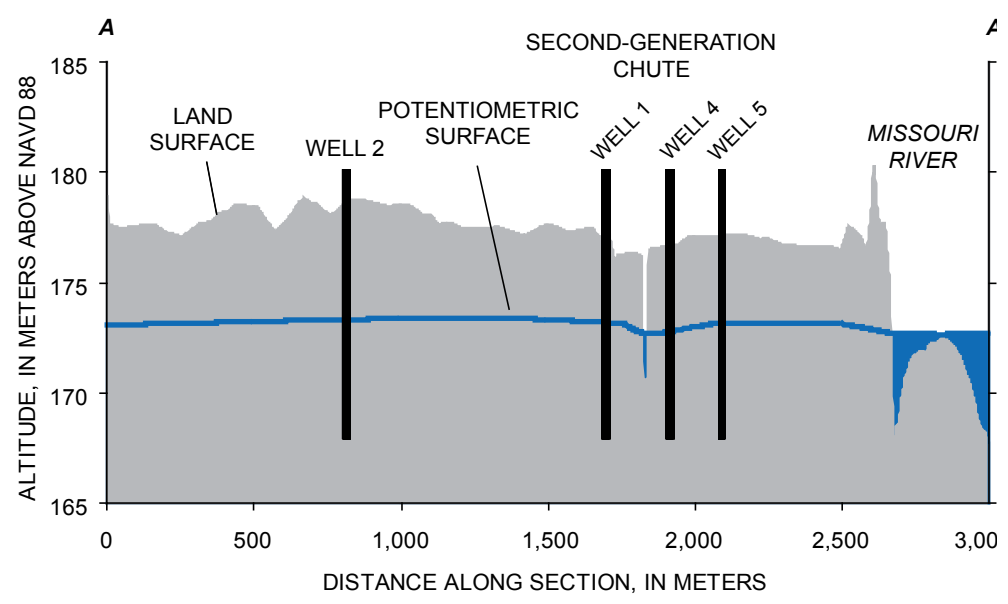

$0^{3}$ WELL AND IDENTIFIER

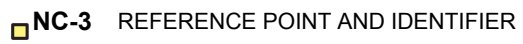

Figure 13. Potentiometric contours, depth to ground water, and hydrologic section $A-A^{\prime}$ for second-generation-chute conditions, Overton Bottoms North, Missouri, July 3, 2003. 


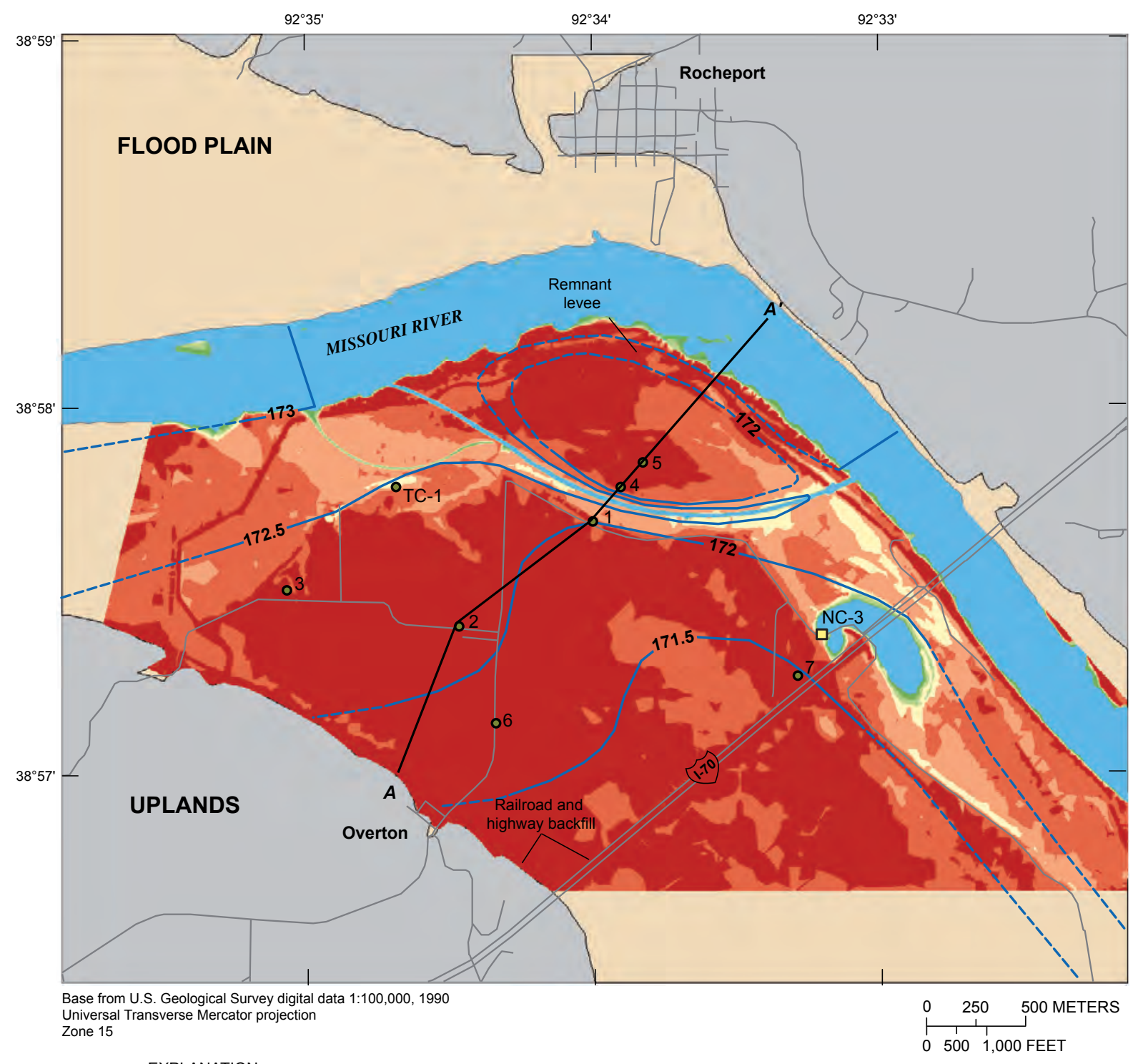

EXPLANATION

DEPTH TO GROUND WATER, IN METERS

Surface water
0 to 1
Greater than 1 to 2
Greater than 2 to 3
Greater than 3 to 4
Greater than 4 to 5
Greater than 5

ROAD

-173- - POTENTIOMETRIC CONTOUR-Shows altitude at which water would have stood in a tightly cased well. Dashed where approximately located. Contour interval 0.5 meter. Datum is NAVD 88

$\boldsymbol{A} \longrightarrow \boldsymbol{A}^{\prime}$ TRACE OF SECTION

$0^{3}$ WELL AND IDENTIFIER

NC-3 REFERENCE POINT AND IDENTIFIER

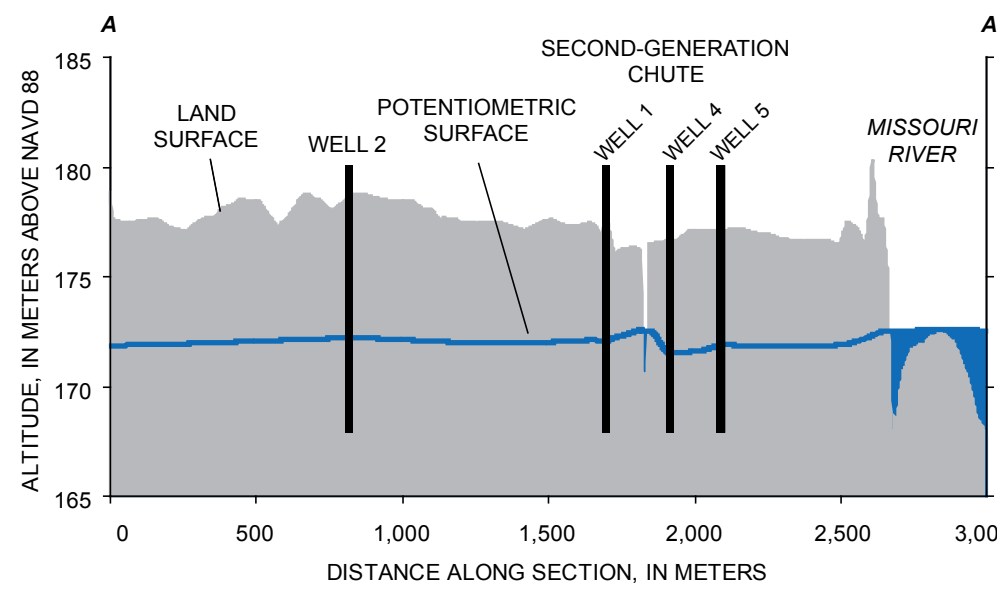

Figure 14. Potentiometric contours, depth to ground water, and hydrologic section $A-A^{\prime}$ for second-generation-chute conditions, Overton Bottoms North, Missouri, December 11, 2003. 


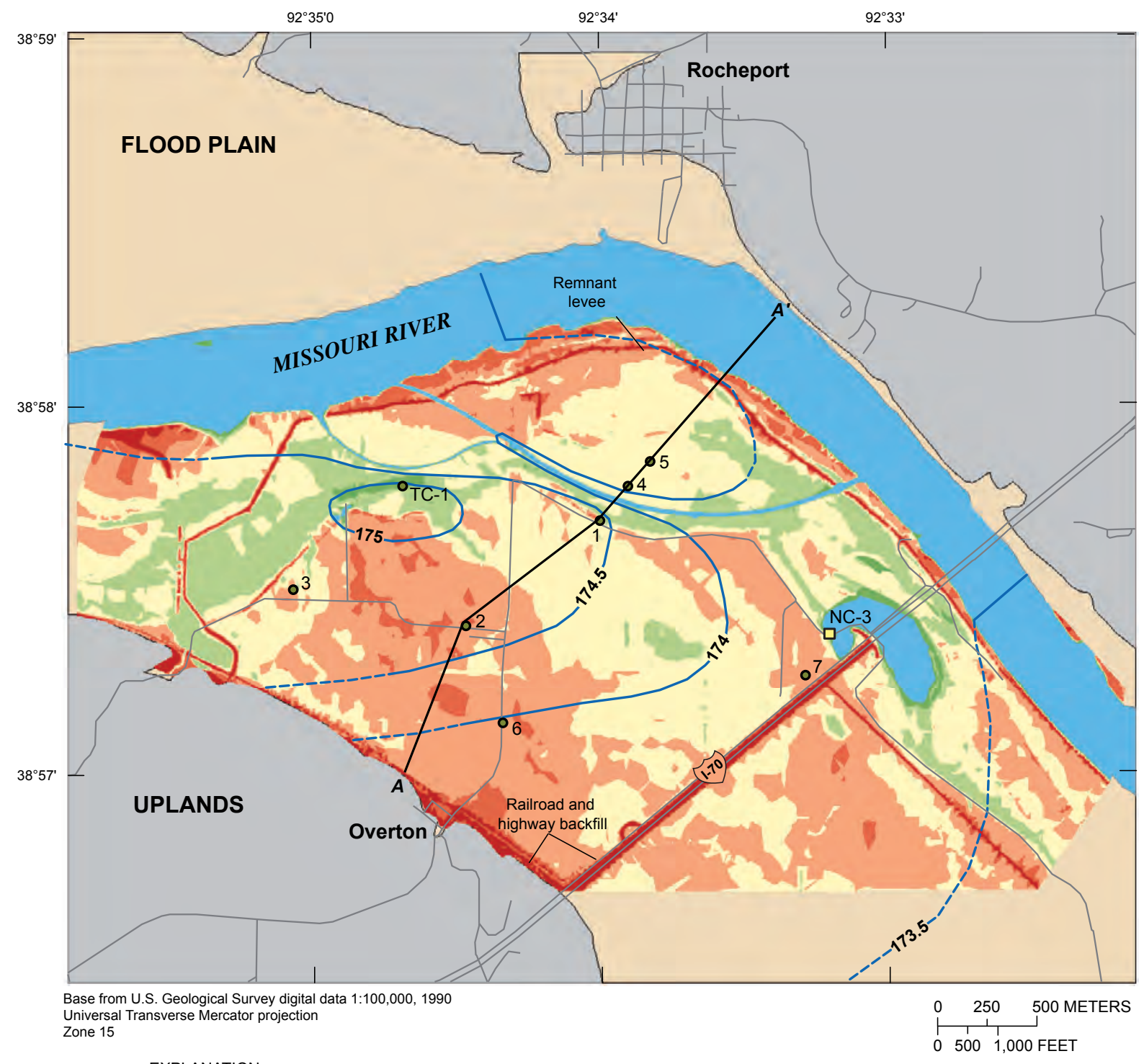

EXPLANATION

DEPTH TO GROUND WATER, IN METERS

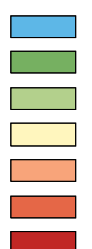

Surface water

0 to 1

Greater than 1 to 2

Greater than 2 to 3

Greater than 3 to 4

Greater than 4 to 5

Greater than 5

ROAD

—175_- POTENTIOMETRIC CONTOUR-Shows altitude at which water would have stood in a tightly cased well. Dashed where approximately located. Contour interval 0.5 meter. Datum is NAVD 88

\section{$\boldsymbol{A} \longrightarrow \boldsymbol{A}^{\prime}$ TRACE OF SECTION}

$0^{3}$ WELL AND IDENTIFIER

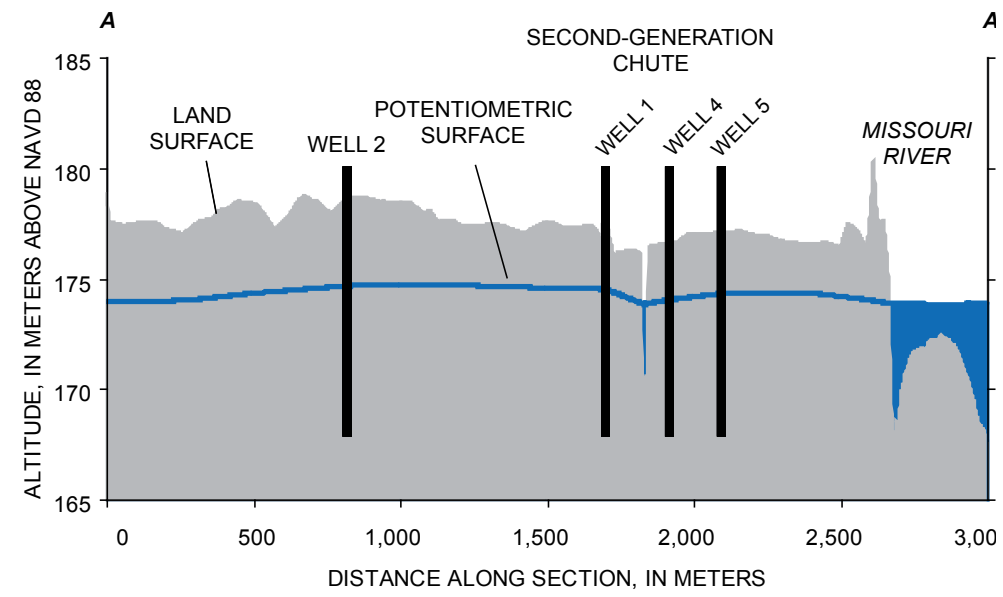

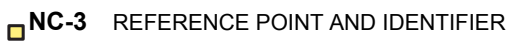

Figure 15. Potentiometric contours, depth to ground water, and hydrologic section $A-A$ ' for second-generationchute conditions, Overton Bottoms North, Missouri, June 23, 2004. 


\section{Seismic Analysis}

A seismic refraction survey of the study area was conducted April 9, 2004, to determine the thickness of the silt/clay top stratum and the depth to the bedrock surface at seven sites (fig. 16). At all sites, an interface between a lower velocity layer and a higher velocity layer was encountered, generally between 5 and $15 \mathrm{~m}$ deep (fig. 17). A second interface between layers of different velocity layer was detected at site 4 at about $20 \mathrm{~m}$. At site 6 , depth to an irregular interface between layers of different velocity ranged between 20 and $40 \mathrm{~m}$.

The velocities of sound for the alluvial deposits expected to be encountered at Overton Bottoms North are listed in table 3 . The range of velocity of sound in unsaturated material generally is lower than the range for saturated material, although the velocity of sound in clay can exceed the velocity of sound for saturated sand and gravel. For most materials listed in table 3 , the upper end of the velocity range is associated with more dense materials located at depth.

The silt/clay and sand materials have similar velocities of sound when unsaturated, and therefore cannot be reliably discriminated. The first interface detected for most seismic survey sites was probably the boundary between unsaturated and saturated alluvial sand; the shallowest depths for the velocity interface are generally deeper than the average thickness for silt/clay top stratum documented in the same area (this volume, chapter 2, fig. 5). The average depth, depth range, and average altitude of detected velocity interfaces for each seismic survey site and the depth to and altitude of the water table measured in nearby monitoring wells on April 9, 2004, are listed in table 4. For sites 1, 2, 3, 4, and 7, the altitude of the first velocity interface is similar to the altitude of the water table measured at nearby wells. This indicates that the first velocity interface at these locations is most likely the water table, although a lithologic change also could be indicated. Site 5 and well 1 are at the same location. For site 5 , the altitude of the first velocity interface is $5.88 \mathrm{~m}$ below the altitude of the water table at well 1 , indicating that the first velocity interface there is most likely a change in lithology. Borehole 82, documented in Holbrook and others (this volume, chapter 2), was located adjacent to site 5; borehole 85 ended in sand $3.7 \mathrm{~m}$ below the ground surface, well above the velocity interface.

For site 6, the altitude of the first velocity interface is 9.9 $\mathrm{m}$ below the altitude of the water table at well 1, $9.8 \mathrm{~m}$ below the altitude of the water table at well 4 , and $9.7 \mathrm{~m}$ below the altitude of the water table at well 5, indicating that the first velocity interface at site 6 most likely is a change in lithology. A deeper velocity interface detected at sites 4 and 6 is at depths typical of bedrock beneath the Missouri River alluvial aquifer. At site 4 this may indicate a change in lithology within the alluvium and at site 6 the higher velocity (greater than $4,800 \mathrm{~m} / \mathrm{s}$, meters per second) indicates the underlying material is most likely limestone. If so, the aquifer is approximately 20 to $35 \mathrm{~m}$ thick at site 6 .

Table 3. Compressional velocity of sound in common Earth materials.

[m/s, meter per second; --, no data; modified from Haeni, 1986]

\begin{tabular}{lcc}
\hline \multicolumn{1}{c}{ Material } & $\begin{array}{c}\text { Unsaturated velocity } \\
(\mathbf{m} / \mathbf{s})\end{array}$ & $\begin{array}{c}\text { Saturated velocity } \\
(\mathbf{m} / \mathbf{s})\end{array}$ \\
\hline Weathered surface material & $120-210^{1}, 305-610^{2}$ & -- \\
Clay & $915-2,740^{2}$ & -- \\
Loess silt and silty sand & $230-760^{3}$ & -- \\
Alluvial sand & $300-1,220^{3}$ & $610-1,830^{2}, 1,070-1,830^{3}$ \\
Alluvial sand and gravel & $360-490^{1}, 460-1,525^{3}$ & $1,220-1,830^{1}, 1,525-2,290^{3}$ \\
Water (sound velocity of saturated materials should be & & -- \\
$\quad$ equal to or greater than sound velocity of water) & $1,460^{1}, 1,430-1,680^{2}$ & -- \\
\hline
\end{tabular}

${ }^{1}$ Clark (1966, p. 204).

${ }^{2}$ Jakosky (1950, p. 660).

${ }^{3}$ Koloski and others (1989). 


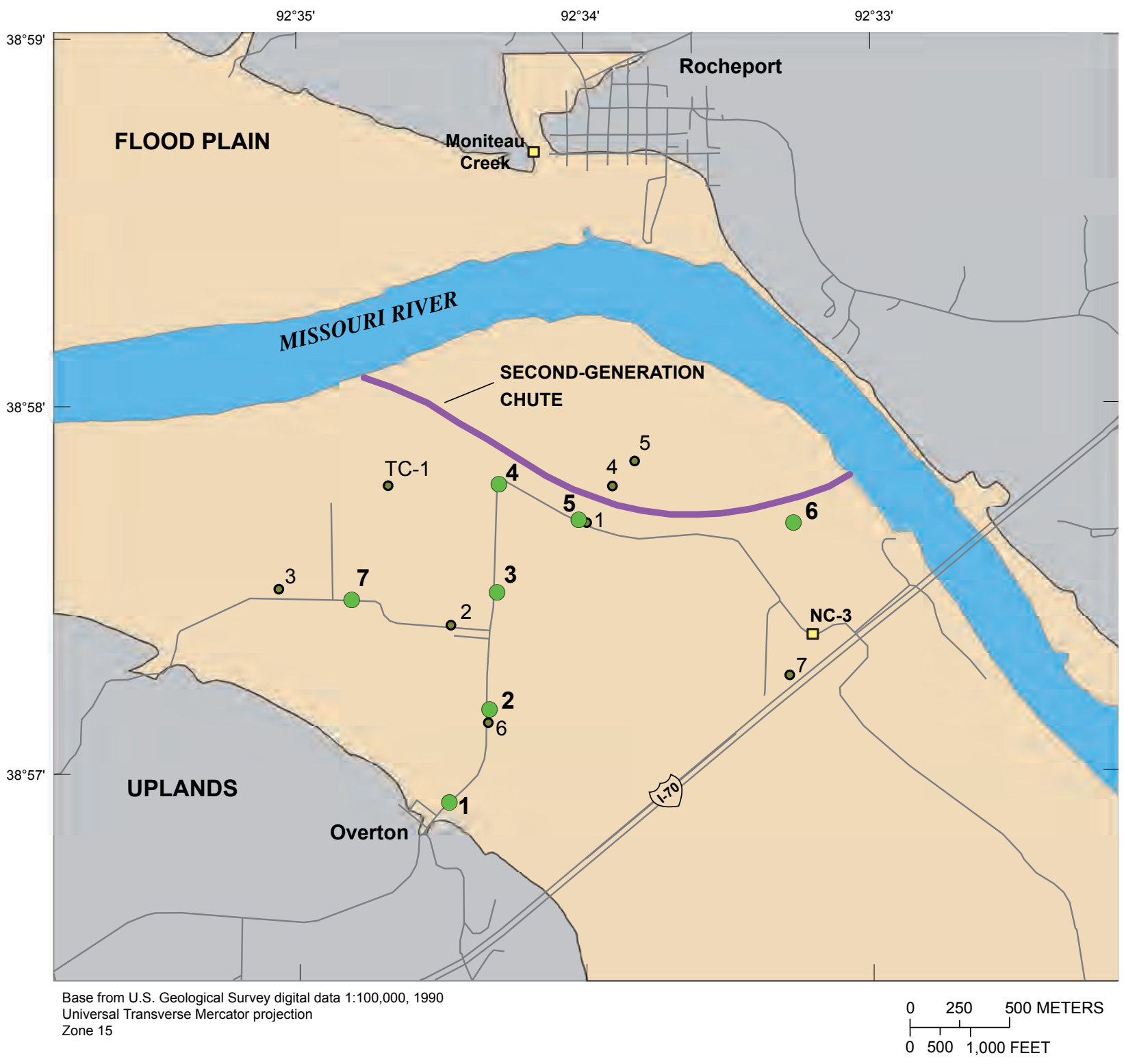

EXPLANATION

$$
\begin{array}{cl}
- & \text { ROAD } \\
0^{3} & \text { WELL AND IDENTIFIER } \\
6 & \text { SEISMIC ARRAY AND NUMBER } \\
\square^{\text {NC-3 }} & \text { REFERENCE POINT AND IDENTIFIER }
\end{array}
$$

Figure 16. Locations of seismic refraction sites at Overton Bottoms North, Missouri, April 9, 2004. 

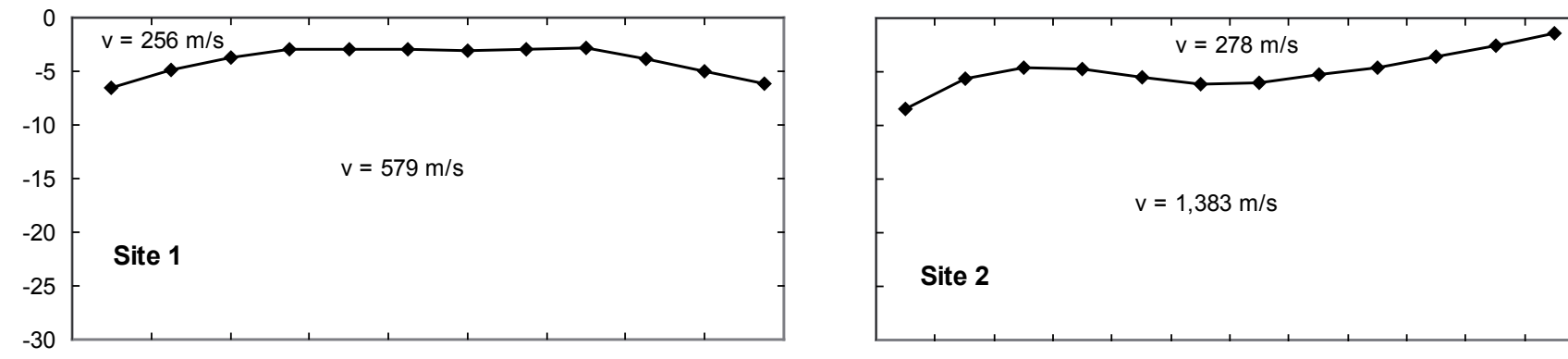

Site 2
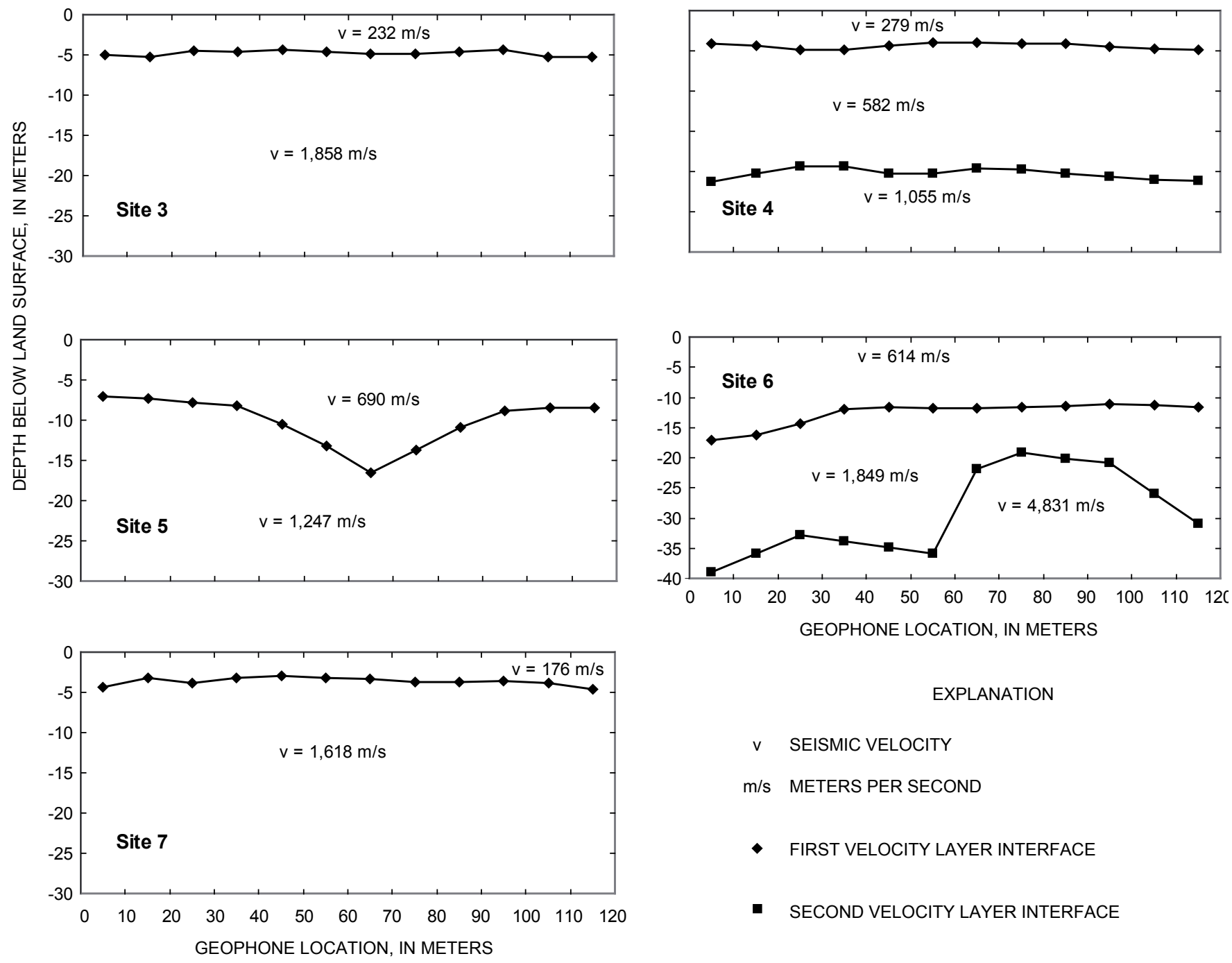

EXPLANATION

v SEISMIC VELOCITY

$\mathrm{m} / \mathrm{s} \quad$ METERS PER SECOND

- FIRST VELOCITY LAYER INTERFACE

- SECOND VELOCITY LAYER INTERFACE

Figure 17. Interpreted seismic sections and velocities of sound from seven seismic refraction survey sites at Overton Bottoms North, Missouri, April 9, 2004. 
Table 4. Comparison of seismic-velocity-interface data and water-level data at Overton Bottoms North, Missouri, April 9, 2004.

[m, meter; --, no data]

\begin{tabular}{|c|c|c|c|c|c|c|c|c|c|c|}
\hline \multirow[b]{2}{*}{$\begin{array}{c}\text { Site } \\
\text { number } \\
\text { (fig. 16) }\end{array}$} & \multirow[b]{2}{*}{$\begin{array}{c}\text { Altitude } \\
(\mathrm{m})\end{array}$} & \multicolumn{3}{|c|}{ First velocity interface } & \multicolumn{3}{|c|}{ Second velocity interface } & \multirow[b]{2}{*}{$\begin{array}{c}\text { Nearest } \\
\text { wells }\end{array}$} & \multirow{2}{*}{$\begin{array}{c}\text { Depth to } \\
\text { water table } \\
04 / 09 / 2004 \\
\text { (m) }\end{array}$} & \multirow[b]{2}{*}{$\begin{array}{l}\text { Altitude } \\
\text { (m) }\end{array}$} \\
\hline & & $\begin{array}{c}\text { Average } \\
\text { depth } \\
\text { (m) }\end{array}$ & $\begin{array}{l}\text { Depth } \\
\text { range } \\
\text { (m) }\end{array}$ & $\begin{array}{c}\text { Average } \\
\text { altitude } \\
\text { (m) }\end{array}$ & $\begin{array}{l}\text { Average } \\
\text { depth } \\
\text { (m) }\end{array}$ & $\begin{array}{c}\text { Depth } \\
\text { range } \\
\text { (m) }\end{array}$ & $\begin{array}{l}\text { Average } \\
\text { altitude } \\
\text { (m) }\end{array}$ & & & \\
\hline 1 & 178.2 & 4.0 & 2.8 to 6.6 & 174.2 & -- & -- & - & Well 6 & 4.5 & 172.6 \\
\hline 2 & 177.5 & 4.9 & 1.4 to 8.5 & 172.6 & -- & -- & -- & Well 6 & 4.5 & 172.6 \\
\hline 3 & 177.9 & 4.8 & 4.3 to 5.3 & 173.1 & -- & -- & -- & Well 2 & 7.2 & 173.3 \\
\hline \multirow[t]{2}{*}{4} & 177.7 & 4.4 & 4 to 4.9 & 173.1 & 20.2 & 19.3 to 21.3 & 157.5 & Well TC-1 & 9.1 & 173.3 \\
\hline & & & & & & & & Well 1 & 6.3 & 173.0 \\
\hline 5 & 177.2 & 10.1 & 7.1 to 16.5 & 167.1 & -- & -- & -- & Well 1 & 6.3 & 173.0 \\
\hline \multirow[t]{3}{*}{6} & 175.7 & 12.7 & 11.1 to 17.1 & 163.1 & 29.3 & 19.2 to 38.9 & 146.5 & Well 1 & 6.3 & 173.0 \\
\hline & & & & & & & & Well 4 & 7.8 & 172.9 \\
\hline & & & & & & & & Well 5 & 9.0 & 172.8 \\
\hline 7 & 178.6 & 3.6 & 2.9 to 4.6 & 175.0 & -- & -- & -- & Well 3 & 6.9 & 173.5 \\
\hline
\end{tabular}

\section{Relations Among Chute Size, River Altitude, and Ground-Water Altitude}

Ground-water altitude is closely related to river altitude at Overton Bottoms North (fig. 5). Well and river hydrographs for pre-chute, first-generation-chute, and second-generationchute conditions indicate the differences in the hydrographs for the three conditions. Although rainfall was slightly greater during pre-chute conditions (table 2), the difference in rainfall among pre-, first-generation-, and second-generation-chute conditions was assumed to be too small to greatly influence ground-water altitude. Recharge for the Missouri River alluvial aquifer has been estimated to be between 2 and 25 percent of rainfall (Fischel and others, 1953; Hedman and Jorgensen, 1990). Compared to pre-chute conditions, rainfall was 0.31 $\mathrm{m}$ less during first-generation-chute conditions and $0.36 \mathrm{~m}$ less during second-generation-chute conditions. Assuming recharge is 20 percent of rainfall, then $0.062 \mathrm{~m}$ less water recharged the aquifer for first-generation-chute conditions than for pre-chute conditions, and $0.072 \mathrm{~m}$ less water recharged the aquifer for second-generation-chute conditions than for prechute conditions. Typical porosity values for alluvial deposits are 40 to 70 percent for clay, 35 to 50 percent for silt, 25 to 50 percent for sand, and 25 to 40 percent for gravel (Freeze and Cherry, 1979). Dividing each recharge difference by a typical porosity for the aquifer (30 percent) estimates the decrease in ground-water level caused by the decrease in recharge. For first-generation-chute conditions, the ground-water level decrease caused by reduced recharge from rainfall could be as much as $0.21 \mathrm{~m}$ during 13 months, or $0.016 \mathrm{~m} / \mathrm{month}$ (meter per month) relative decrease in ground-water level. For second-generation-chute conditions, the ground-water level decrease potentially caused by reduced recharge could be as much as $0.24 \mathrm{~m}$ during 17 months or $0.014 \mathrm{~m} /$ month decrease in ground-water level.

Water flow in the chute occurred less frequently during first-generation-chute conditions than during second-generation-chute conditions. During first-generation-chute conditions, water flowed in the chute from upstream 11 percent of the time; it was in backwater (that is flowing in from only the outlet) 6 percent of the time and dry 83 percent of the time. During second-generation-chute conditions water flowed in the chute 96 percent of the time; it was in backwater 4 percent of the time and was never dry. The wider and deeper secondgeneration chute increased the interaction between surface water and ground water at the study area, because it flowed most of the time and the bottom of the chute was below the water table.

Median river altitude was $173.9 \mathrm{~m}$ during pre-chute conditions, $172.2 \mathrm{~m}$ during first-generation-chute conditions, and $171.9 \mathrm{~m}$ during second-generation-chute conditions. A direct comparison of ground-water altitude of wells TC-1, 1, 2, and 3 between pre-chute, first-generation-chute, and second-generation-chute conditions does not take into account the decrease in river altitude from pre-chute to second-generation-chute conditions and overestimates the effect of chute construction on the decrease in ground-water altitude. A comparison of the difference between ground-water altitude and river altitude among the three periods more closely indicates the relative effect of chute construction on ground-water altitude by partially removing the effect of river stage. In addition, variations in the pre-chute, first-generation-chute, and secondgeneration-chute hydrographs introduce uncertainty into the analysis. When river altitude decreases, the difference between ground-water altitude and river altitude is greater because river altitude decreases faster than ground-water altitude responds. Similarly, when river altitude increases, the difference between ground-water altitude and river altitude is less. Falling, rising, 
and steady river altitude conditions were determined based on the cumulative change in river altitude during the 5 days preceding the ground-water altitude measurement. The 5-day period and the amount of change in river stage were determined through trial and error to provide a period long enough to have an effect on ground-water altitude and ensure the amount of river altitude change was sufficient to measurably change ground-water altitude. If river altitude decreased more than $0.1 \mathrm{~m}$ during this period, river-altitude conditions were falling. If river altitude increased more than $0.1 \mathrm{~m}$ during this period, river-altitude conditions were rising. If river altitude did not change more than $0.1 \mathrm{~m}$ during this period, river-altitude conditions were steady. The boxplots of the difference between measured ground-water altitude and river altitude for combined river-altitude conditions and for falling, rising, and steady river-altitude conditions are shown in figure 18 .

The change in the difference between ground-water and river altitude from pre-chute to first-generation-chute to second-generation-chute conditions indicates the effect on ground-water altitude of chute construction at Overton Bottoms North. The change in median difference between chute conditions for wells TC-1, 1, 2, and 3 for each river-altitude condition are listed in table 5.

The increase in the median difference between groundwater and river altitude at well TC-1 from pre-chute to secondgeneration-chute conditions for combined river-altitude conditions was $0.09 \mathrm{~m}$ (table 5). For all river-altitude conditions, the median difference between ground-water and river altitude at well TC-1 was smaller during pre-chute conditions than during first-generation-chute conditions (fig. 18). This increase in the water level difference indicates that the first-generation chute either increased recharge to the aquifer or caused less drainage from the aquifer to the river near well TC-1.

Because the first-generation chute was close to well TC-1, a more rapid ground-water altitude response to river stage at TC-1 (via the chute) would be expected when river water flowed in the chute, resulting in a smaller difference between ground-water and river altitude. However, chute construction allowed the Missouri River to inundate Overton
Bottoms North more frequently, and at a lower stage, because the chute breached the levee that previously had protected the flood plain from flooding. The top of the breached levee was approximately $180 \mathrm{~m}$. River altitude (fig. 3) exceeded landsurface altitude (fig. 2) near TC-1 during most of June 2001. Well TC-1 is located in a low-lying wetland area of Overton Bottoms North, where flood water ponds and does not rapidly drain from the area as river altitude decreases. Inundation of the flood plain and topographic capture of flood waters in June 2001 and high river altitude likely increased ground-water recharge and raised ground-water altitude. After this period of inundation, river altitude fell from June 2001 to January 2002, and the median difference between ground-water and river altitude became large because the river altitude decreased more quickly than ground-water altitude could respond.

For all river-altitude conditions, the median difference between ground-water and river altitude at well TC-1 was the same or larger during first-generation-chute conditions than during second-generation-chute conditions, and the median difference was smaller for pre-chute conditions than for second-generation-chute conditions. The path of the second generation chute is farther from TC-1 than the path of the firstgeneration chute. Construction of the second-generation chute decreased the median difference between ground-water and river altitude for second-generation-chute conditions compared to first-generation-chute conditions, most likely because the bottom of the second-generation chute intersects more transmissive sand deeper in the aquifer than the first-generation chute causing a quicker ground-water altitude response to river-altitude change. However, the flood plain was inundated several times in June and July 2004, and flood water and high river stage during these events increased ground-water altitude. The increase in ground-water altitude compared to river altitude at well TC-1 during first-generation-chute and secondgeneration-chute conditions indicates that inundation of the flood plain in the absence of protective levees and focused recharge in this low-lying area increased the ground-water altitude more than the drainage of the aquifer into the first- or second-generation chute decreased the ground-water altitude.

Table 5. Change in media difference between ground-water and river altitude for wells TC-1, 1, 2, and 3 for combined, falling, rising, and steady river-altitude conditions.

[m., meter]

\begin{tabular}{|c|c|c|c|c|c|c|c|c|c|c|c|c|}
\hline \multirow[b]{3}{*}{$\begin{array}{l}\text { River- } \\
\text { altitude } \\
\text { condition }\end{array}$} & \multicolumn{12}{|c|}{ Median ground-water altitude change (m) } \\
\hline & \multicolumn{3}{|c|}{ Well TC-1 } & \multicolumn{3}{|c|}{ Well 1} & \multicolumn{3}{|c|}{ Well 2} & \multicolumn{3}{|c|}{ Well 3} \\
\hline & $\begin{array}{c}\text { Pre- } \\
\text { chute to } \\
\text { first- } \\
\text { chute }\end{array}$ & $\begin{array}{l}\text { First- } \\
\text { chute to } \\
\text { second- } \\
\text { chute }\end{array}$ & $\begin{array}{l}\text { Pre- } \\
\text { chute to } \\
\text { second- } \\
\text { chute }\end{array}$ & $\begin{array}{c}\text { Pre- } \\
\text { chute to } \\
\text { first- } \\
\text { chute }\end{array}$ & $\begin{array}{l}\text { First- } \\
\text { chute to } \\
\text { second- } \\
\text { chute }\end{array}$ & $\begin{array}{l}\text { Pre- } \\
\text { chute to } \\
\text { second- } \\
\text { chute }\end{array}$ & $\begin{array}{c}\text { Pre- } \\
\text { chute to } \\
\text { first- } \\
\text { chute }\end{array}$ & $\begin{array}{l}\text { First- } \\
\text { chute to } \\
\text { second- } \\
\text { chute }\end{array}$ & $\begin{array}{l}\text { Pre- } \\
\text { chute to } \\
\text { second- } \\
\text { chute }\end{array}$ & $\begin{array}{c}\text { Pre- } \\
\text { chute to } \\
\text { first- } \\
\text { chute }\end{array}$ & $\begin{array}{c}\text { First- } \\
\text { chute to } \\
\text { second- } \\
\text { chute }\end{array}$ & $\begin{array}{c}\text { Pre- } \\
\text { chute to } \\
\text { second- } \\
\text { chute }\end{array}$ \\
\hline Combined & 0.25 & -0.16 & 0.09 & -0.22 & -0.39 & -0.61 & -0.35 & -0.54 & -0.89 & -0.20 & -0.29 & -0.49 \\
\hline Falling & .18 & -.14 & .04 & -.27 & -.32 & -.59 & -.38 & -.51 & -.89 & -.25 & -.18 & -.43 \\
\hline Rising & .37 & -.35 & .02 & -.22 & -.46 & -.68 & .16 & -.93 & -.77 & -.13 & -.35 & -.48 \\
\hline Steady & .18 & 0 & .18 & -.11 & -.27 & -.38 & -.12 & -.29 & -.41 & -.12 & -.21 & -.33 \\
\hline
\end{tabular}




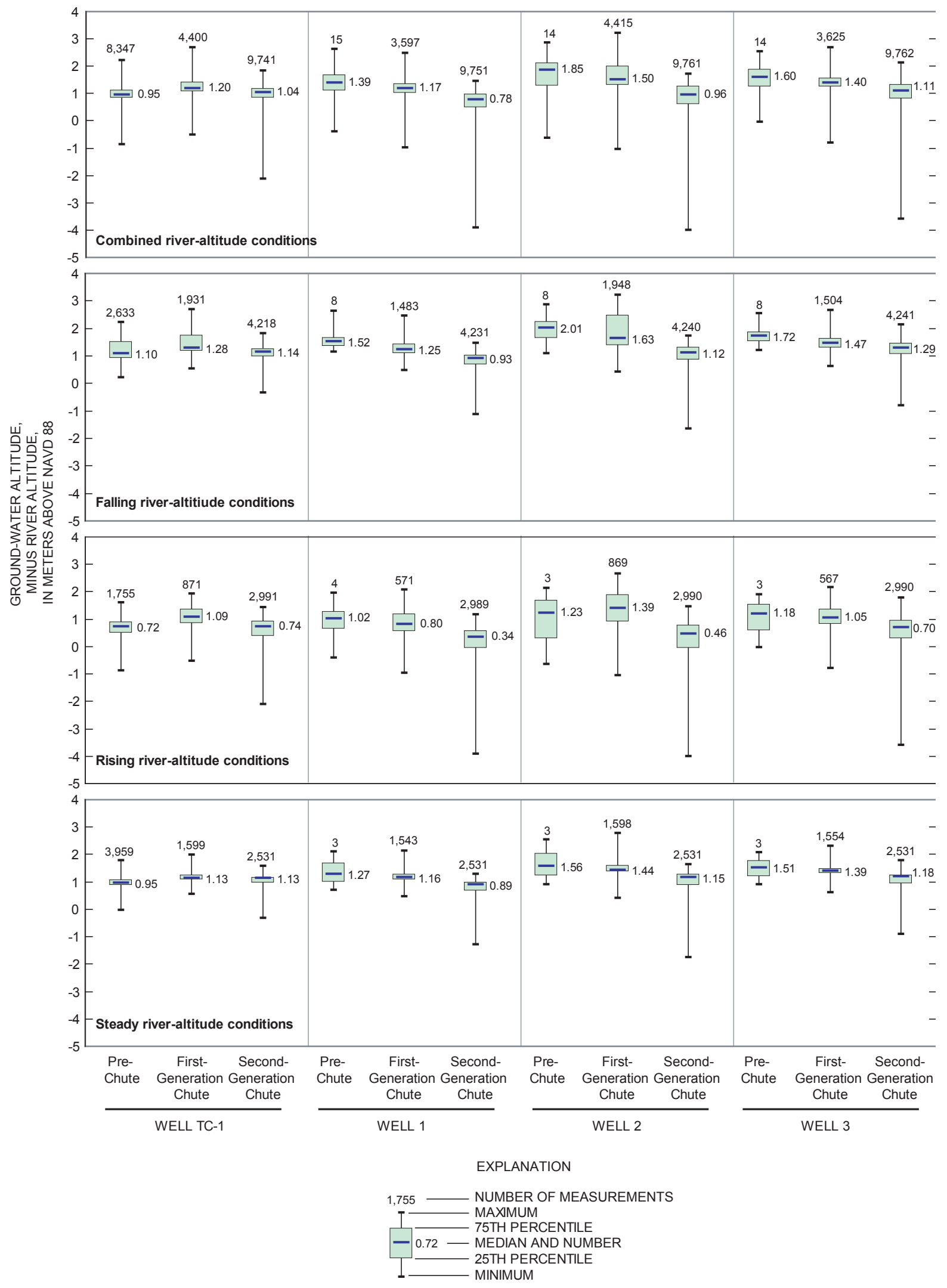

Figure 18. The maximum, 75th percentile, median, 25th percentile, and minimum of the difference between measured ground-water altitude and river altitude for combined, falling, rising, and steady river-altitude conditions, Overton Bottoms North, Missouri. 
Although the second-generation chute decreased ground-water altitude from first-generation-chute conditions, the increased distance of well TC-1 from the second-generation chute decreased the rate of response of ground water to changes in river altitude and raised ground-water altitude at well TC-1.

Well 1 is $120 \mathrm{~m}$ from the chute and is, therefore, one of the best wells for characterizing chute effects on ground-water altitude near the chute. The change in median ground-water altitude at well 1 from pre-chute to second-generation-chute conditions for combined river-altitude conditions was $-0.61 \mathrm{~m}$ (table 5). For all river-altitude conditions the median difference between ground-water and river altitude decreased from pre-chute to first-generation-chute and from first-generation-chute to second-generation-chute conditions for well 1, indicating the construction of the first-generation chute and the second-generation chute caused ground-water altitude to more closely follow changes in river altitude (fig. 18). Groundwater recharge from flood inundation during pre-chute and first-generation-chute conditions did not have the large effect on ground-water altitude at well 1 as at well TC-1. Well 1 is located on higher ground than TC-1, and flood water typically drains from the area as river altitude decreases (fig. 2). The path of the first-generation chute and second-generation chute are identical near well 1 . The decrease in the difference between ground-water and river altitude most likely occurred because the bottom of the second-generation chute intersects the more transmissive sand of the aquifer, allowing groundwater altitude to more closely track river and chute altitude.

Well 2 is 1,350 $\mathrm{m}$ from the Missouri River, $875 \mathrm{~m}$ from the second-generation chute, and $820 \mathrm{~m}$ from the first-generation chute. The change in median ground-water altitude at well 2 from pre-chute to second-generation-chute conditions for combined river-altitude conditions was $-0.89 \mathrm{~m}$ (table 5). For combined, falling, and steady river-altitude conditions, the median difference between ground-water and river altitude decreased from pre-chute to first-generation-chute and from first-generation-chute to second-generation-chute conditions for well 2, indicating the construction of the first-generation chute and then the second-generation chute caused groundwater altitude to more closely follow changes in river altitude (fig. 18). However, for rising river-altitude conditions the median difference between ground-water and river altitude for well 2 increased from pre-chute to first-generation-chute conditions, and then decreased from first-generation-chute to second-generation-chute conditions. This is similar to the response of ground-water altitude for well TC-1 during all river-altitude conditions. Inundation of the flood plain in June 2001 (fig. 5) recharged the aquifer and caused higher than normal ground-water altitude near well 2. High ground-water altitude and small increases in river altitude during first-generation-chute conditions caused the increase in the median difference between ground-water and river altitude at well 2 between pre-chute and first-generation-chute conditions for rising river-altitude conditions.

Well 3 is $920 \mathrm{~m}$ from the Missouri River, 1,150 $\mathrm{m}$ from the second-generation chute, and $745 \mathrm{~m}$ from the first-genera- tion chute. The change in median ground-water altitude at well 3 from pre-chute to second-generation-chute conditions for combined river-altitude conditions was $-0.49 \mathrm{~m}$ (table 5). For all river-altitude conditions the median difference between ground-water and river altitude decreased from pre-chute to first-generation-chute, and from first-generation-chute to second-generation-chute conditions for well 3 . The construction of the first-generation chute and the second-generation chute caused ground-water altitude to more closely follow changes in river altitude (fig. 18). The response of well 3 to hydrologic changes at Overton Bottoms North is similar to that of well 1. Ground-water recharge from flood inundation during pre-chute and first-generation-chute conditions did not have the large effect on ground-water altitude at well 3 as it did for well TC-1 and well 2. Well 3 is on high ground and flood water drains from the area after inundation as river altitude decreases (fig. 2). The path of the second-generation chute is farther from well 3 than the path of the first-generation chute. The decrease in the difference between ground-water and river altitude most likely occurred because the bottom of the second-generation chute intersects the more transmissive sand of the aquifer, allowing ground-water altitude near well 3 to more closely track river and chute altitude.

A transect constructed from wells 1,4 , and 5 perpendicular to the axis of the second-generation chute illustrates the spatial and temporal variability of ground-water altitudes. Hydrologic section A-A' (figs. 13 to 15) shows the potentiometric surface across this transect for selected times during second-generation-chute conditions. Hourly monitoring of ground-water levels in these wells measured the ground-water altitude response to changes in water-level altitude in the chute. The altitude of the water level in the chute, groundwater altitude, water depth in the chute, depth from land surface to ground water, and the minimum, 25 th percentile, median, 75th percentile, and maximum depth to ground water for wells 1, 4, and 5 from June 28, 2003 to August 21, 2004, are shown in figure 19. Median depth to ground water was $5.04 \mathrm{~m}$ at well 1, $4.62 \mathrm{~m}$ at well 4, and $4.26 \mathrm{~m}$ at well 5 .

Ground-water and river-altitude conditions were similar on March 23, 1999 (fig. 9) and June 23, 2004 (fig. 15). A comparison of hydrologic section A-A' for these two times indicates the decrease in ground-water altitude caused by the second-generation chute near wells 1, 4, and 5. From pre-chute to second-generation-chute conditions, median ground-water altitude decreased $0.61 \mathrm{~m}$ at well 1 . Wells 4 and 5 were not installed until the second-generation chute was constructed and pre-chute ground-water altitude data were not available. However, hydrologic conditions at well 1 are similar to wells 4 and 5, and ground-water altitude most likely decreased a like amount. An estimate of median depth to ground water during pre-chute conditions at these wells can be made by subtracting the median decrease calculated for well $1(0.61 \mathrm{~m})$ from the median depth to ground water calculated from hourly groundwater altitude measurements. The estimated median depth to ground water during pre-chute conditions was $4.43 \mathrm{~m}$ for well 1, $4.01 \mathrm{~m}$ for well 4 , and $3.65 \mathrm{~m}$ for well 5 . 
The transect illustrates the fine-scale dynamics of groundwater and surface-water interactions that can be expected in an alluvial flood-plain environment (fig. 19). Near simultaneous peaks for surface water and ground-water wells indicate rapid interaction through transmissive sediments. However, responses can also be spatially variable. For example, during low-water conditions June, 2003 to December, 2003, groundwater altitudes adjacent to the chute in well 1 were higher than those in well 5, located about twice the distance from the chute on the island. During and after the April 2004 flood, however, the relative altitudes were reversed with ground water ponded under the island and presumably draining toward wells 4 and 5. In general, ground water was mounded at shallower depths below the ground surface in the middle of the island (well 5) compared to wells adjacent to the chute (fig. 19).

Chute construction has resulted in a decrease in the difference between ground-water altitude and river altitude in most areas of Overton Bottoms North. The decrease in the difference between ground-water and river altitude is most notable for second-generation-chute conditions. However, chute construction has allowed the Missouri River to inundate Overton Bottoms North more frequently, and at a lower stage, because the levee that previously protected the flood plain was breached at the chute inlet and outlet. If the levee was still in place, and no chutes existed, the Missouri River would not have inundated the flood plain at Overton Bottoms North during the study period. The construction of the chutes has resulted in more frequent surface recharge to the aquifer from flood inundation in low-lying areas. The increase in the difference between ground-water and river altitude was greatest during first-generation-chute conditions, when surface recharge from flood water caused ground-water altitude to increase more than drainage of the aquifer to the first-generation chute, and the Missouri River caused ground-water altitude to decrease.

The decrease in the difference between ground-water and river altitude from pre-chute to second-generation-chute conditions for most areas of Overton Bottoms North indicates that ground-water altitude more closely corresponds to river altitude with the presence of a second-generation chute. Ground-water altitude in areas of the aquifer closer to the river typically respond to river-altitude fluctuations more rapidly than areas farther from the river. Rising river altitude causes ground-water altitude to increase as water goes into bank storage, and falling river altitude causes ground-water altitude to decrease. At Overton Bottoms North, construction of the second-generation chute added another river channel in the study area more inland from the main river channel. This increased the effect of river-altitude changes on ground-water altitude by adding more opportunity for exchange between surface and ground water, resulting in more variable ground-water altitude after the chute was constructed.

During low river stages, the decrease in ground-water altitude with respect to river altitude will most likely reduce or eliminate the effect of ground water on wetland recharge and drainage, especially those that are located near the second- generation chute. However, the reconnection of the flood plain with the Missouri River caused by chute construction and removal of levee protection will increase the effect of high river stage on wetland stage by increasing flood frequency. More frequent flood inundation of low-lying areas combined with slow wetland drainage may increase the area occupied by wetlands during periods of high river stage. When river stage remains low, lack of inundation and a lower ground-water altitude will most likely reduce the water that is available to wetlands. Therefore, chute construction at Overton Bottoms North had the net effect of making wetlands drier during dry periods, and breaching of the levees caused the wetlands to be wetter during and immediately after flood periods.

\section{Summary}

Overton Bottoms North is located along the Missouri River near the towns of Rocheport and Overton, Missouri, and was acquired by the USACE after the floods of 1993 and 1995. In 2000, the USACE constructed a chute at Overton Bottoms North to provide shallow water habitat in the Missouri River for native fish. The USGS collected pre-chute hydrologic data between June 1998 and May 1999, and between June 1999 and July 2000. Hydrologic monitoring resumed at Overton Bottoms North after construction of this first-generation chute; data were collected between June 2001 and June 2002. In 2003, the side-channel chute was deepened, widened, and realigned. Hydrologic data for this second-generation chute were collected between June 2003 and October 2004.

The hydrology at Overton Bottoms North is affected by intermittent seasonal flooding, the interchange of water between the Missouri River and wetlands via ground-water flow during normal river stage, flow in the chute, and local precipitation. Shallow wetlands are most affected by rainfall and flood inundation, whereas deeper wetlands and scours are most affected by ground-water fluctuations caused by riverand chute-stage changes. Variability in rainfall during the three monitoring periods was considered to have a minimal effect on ground-water altitudes.

A seismic refraction survey of the study area was conducted April 9, 2004, to determine the thickness of the silt/clay top stratum and the depth to the bedrock surface at seven sites. At all sites, an interface between a lower velocity layer and a higher velocity layer was encountered, generally between 5 and $15 \mathrm{~m}$ deep; however, typical velocities and comparisons with borehole data indicated that this velocity interface probably resulted from the contrast between saturated and unsaturated alluvium rather than a lithologic difference. Depth to a second velocity interface was detected at site 4 at about $20 \mathrm{~m}$. At site 6, depth to a second irregular interface ranged between 20 and $40 \mathrm{~m}$. These velocity interfaces probably resulted from lithologic contrasts within the alluvium and the contact of alluvium on limestone bedrock. 

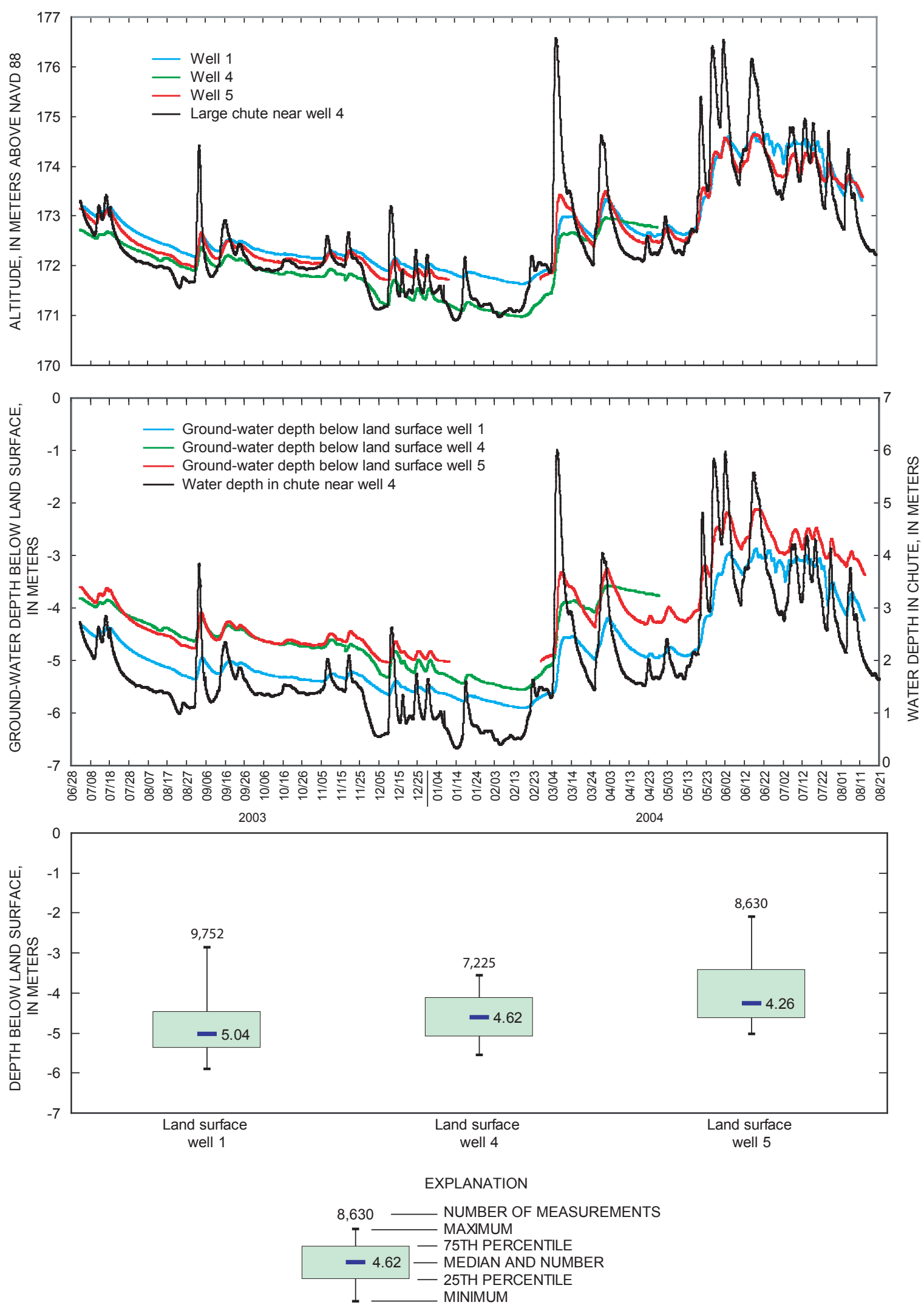

Figure 19. Chute and ground-water altitude, water depth in chute, depth to ground water below land surface, and the minimum, 25th percentile, median, 75th percentile, and maximum depth to ground water below land surface for wells 1, 4, and 5 during second-generation-chute conditions at Overton Bottoms North, Missouri, from June 28, 2003 to August 21, 2004. 
Comparing depth to ground water and potentiometric surfaces for pre-chute, first-generation-chute, and second-generation-chute conditions shows the variability of the surfacewater/ground-water interaction at the study site. Although the effect of chute construction on ground-water flow is shown by the drainage of ground water into the chute, especially during second-generation-chute conditions, the constantly changing river stage, variable rainfall, and rapid response of ground water to these changes illustrate the constantly changing nature of ground-water flow at the study site.

Ground-water altitude is closely related to river-stage altitude at Overton Bottoms North. Water flow in the chute occurred less frequently during first-generation-chute conditions than during second-generation-chute conditions. The wider and deeper second-generation chute increased the interaction between surface water and ground water at the study area because it flowed most of the time, and the bottom of the chute was below the water table.

Effects of river altitude on ground-water altitude varied systematically with stage of chute construction. Depth to ground water was least for pre-chute conditions, greater for first-generation-chute conditions, and largest for second-generation-chute conditions at most wells.

Ground-water response, however, also depended on topographic characteristics of a site and distance from the chute or river. For example, well TC-1 (located in a low-lying wetland area adjacent to the first-generation chute), showed an increase of $0.09 \mathrm{~m}$ in the median difference between groundwater altitude and river altitude from pre-chute to secondgeneration-chute conditions. In contrast, for wells 1,2 , and 3 (located at higher land-surface altitudes), the differences were $-0.61 \mathrm{~m},-0.89 \mathrm{~m}$, and $-0.49 \mathrm{~m}$, respectively, indicating overall lowering of the ground-water altitude relative to the river. In the case of TC-1, inundation of the flood plain by the Missouri River in the absence of protective levees increased the ground-water altitude more than drainage of the aquifer into the first- or second-generation chute decreased ground-water altitude. For wells 1, 2, and 3, generally declining differences between ground-water and river altitudes pre-chute-, to firstgeneration-chute-, to second-generation-chute conditions are attributed to enhanced drainage into the chutes. In particular, intersection of the bottom of the second-generation chute with the highly transmissive sand of the alluvial aquifer appears to have increased the hydrologic interaction between the chute and ground water.

A transect of three wells $(1,4$, and 5) perpendicular to the axis of the side-channel chute confirmed the fine-scale variability of ground-water dynamics in the flood-plain environment. The data showed that ground-water altitudes responded rapidly to surface-water fluctuations, indicating flow through very transmissive sediment. Moreover, the data documented the tendency for ground-water depths to be slightly less in wells away from the chute.

Chute construction has resulted in a decrease in the difference between ground-water and river altitude in most areas of Overton Bottoms North. However, chute construc- tion has allowed the Missouri River to inundate the area more frequently and at a lower stage because the levee that previously protected the flood plain was breached at the chute inlet and outlet. If the levee was still in place, and no side-channel chutes existed, the Missouri River would not have inundated the flood plain at Overton Bottoms North during the study period. Chute construction has resulted in more frequent surface recharge to the aquifer from flood inundation in low-lying areas.

The decrease in the difference between ground-water and river altitude from pre-chute to second-generation-chute conditions for most areas of Overton Bottoms North indicates that ground-water altitude more closely corresponds to river altitude after construction of the chutes. Construction of the second-generation chute added another river channel in the study area more inland from the main river channel. This increased the effect of river altitude changes on ground-water altitude resulting in more variable ground-water altitude after the chute was constructed.

During low river stages, the decrease in ground-water altitude with respect to river altitude most likely will diminish ground water recharge of wetlands, especially those that are located near the second-generation chute. However, the reconnection of the flood plain with the Missouri River caused by chute construction and removal of levee protection will increase the effect of high river stage on wetland stage by allowing more frequent flooding and recharge of the aquifer through the chute banks. More frequent flood inundation of low-lying areas combined with slow wetland drainage may increase the area occupied by wetlands during periods of high river stage. When river stage remains low, lack of inundation and a lower ground-water altitude will most likely decrease water available to wetlands. Therefore, chute construction at Overton Bottoms North had the net effect of making wetlands drier during dry periods and breaching of the levees caused wetlands to be wetter during and immediately after flood periods.

\section{References Cited}

Blevins, D.W., 2004, Hydrology and cycling of nitrogen and phosphorous in Little Bean Marsh-a remnant riparian wetland along the Missouri River in Platte County, Missouri, 1996-1997: U.S. Geological Survey Scientific Investigations Report 2004-5171, 78 p.

Clark, S.P., ed., 1966, Handbook of physical constants: New York, Geological Society of America, Memoir 97, 587 p.

Emmett, L.F., and Jeffery, H.G., 1968, Reconnaissance of the ground-water resources of the Missouri River alluvium between St. Charles and Jefferson City, Missouri: U.S. Geological Survey Hydrologic Investigations Atlas HA-315, 1 sheet, scale 1:125,000. 
Emmett, L.F., and Jeffery, H.G., 1969a, Reconnaissance of the ground-water resources of the Missouri River alluvium between Kansas City, Missouri and the Iowa border: U.S. Geological Survey Hydrologic Investigations Atlas HA-336, 1 sheet, scale 1:125,000.

Emmett, L.F., and Jeffery, H.G., 1969b, Reconnaissance of the ground-water resources of the Missouri River alluvium between Jefferson City and Miami, Missouri: U.S. Geological Survey Hydrologic Investigations Atlas HA-340, 1 sheet, scale 1:125,000.

Emmett, L.F., and Jeffery, H.G., 1970, Reconnaissance of the ground-water resources of the Missouri River alluvium between Miami and Kansas City, Missouri: U.S. Geological Survey Hydrologic Investigations Atlas HA-344, 1 sheet, scale 1:125,000.

Fischel, V.C., Searcy, J.K., and Rainwater, F.H., 1953, Water resources of the Kansas City area, Missouri and Kansas: U.S. Geological Survey Circular 273, 52 p.

Freeze, R.A., and Cherry, J.A., 1979, Groundwater: Englewood Cliffs, N.J., Prentice-Hall, 604 p.

Funk, J.L., and Robinson, J.W., 1974, Changes in the channel of the Lower Missouri River and effects on fish and wildlife: Missouri Department of Conservation Aquatic Service, $112 \mathrm{p}$.

Gann, E.E., Harvey, E.J., Barks, J.H., and Fuller, D.L., 1971, Water resources of northeastern Missouri: U.S. Geological Survey Hydrologic Investigations Atlas HA-372, 4 sheets.

Global Water Instrumentation, Inc., 2002, WL15 Water Level Logger User's Guide: Gold River, Calif., 40 p.

Haeni, F.P., 1986, Application of seismic-refraction techniques to hydrologic studies: U.S. Geological Survey Open-File Report 84-746, 144 p.

Hedman, E.R., and Jorgensen, D.G., 1990, Surface- and ground-water interaction and hydrologic budget of the Missouri River Valley aquifer between Yankton, South Dakota, and St. Louis, Missouri: U.S. Geological Survey Hydrologic Investigations Atlas HA-721, 1 sheet, scale 1:1,500,000.

Jacobson, R.B. and Kelly, B.P., 2004, Hydrology, in, Chapman, D.C., Ehrhardt, E.A., Fairchild, J.F., Jacobson, R.B., Kelly, B.P., Mabee, W.R., Poulton, B.C., and Sappington, L.C., Ecological dynamics of wetlands at Lisbon Bottom, Big Muddy National Fish and Wildlife Refuge, Missouri: U.S. Geological Survey Open-File Report 2004-1036, p. 13-36, accessed 2005, at URL http://www.cerc.usgs.gov/ pubs/MoRiver/OFR_2004-1036.htm.
Jacobson, R.B., Johnson, H.E., Laustrup, M.S., D’Urso, G.J., and Reuter, J.M., 2004, Physical habitat dynamics in four side-channel chutes, Lower Missouri River: U.S. Geological Survey Open-File Report 2004-1071, 60 p., accessed 2005 at URL http://www.cerc.usgs.gov/pubs/MoRiver/OFR 2004-1071/index.htm.

Jakosky, J.J., 1950, Exploration geophysics: Los Angeles, Trija Publishing Co., 1,195 p.

Kelly, B.P., 2001, Relations among river stage, rainfall, ground-water levels, and stage at two Missouri River floodplain wetlands: U.S. Geological Survey Water-Resources Investigations Report 01-4123, 18 p.

Kelly, B.P., and Blevins, D.W., 1995, Vertical hydraulic conductivity of soil and potentiometric surface of the Missouri River alluvial aquifer at Kansas City, Missouri and Kansas, August 1992 and January 1993: U.S. Geological Survey Open-File Report 95-322, 19 p.

Koloski, J.W., Schwarz, S.D., and Tubbs, D.W., 1989, Geotechnical properties of geologic materials: Engineering Geology in Washington, v. 1, Washington Division of Geology and Earth Resources Bulletin 78, 10 p.

National Oceanic and Atmospheric Administration, 1998, Climatological data annual summary, Missouri: Asheville, N.C., National Climate Data Center, v. 102, no. 13, 26 p.

National Oceanic and Atmospheric Administration, 1999, Climatological data annual summary, Missouri: Asheville, N.C., National Climate Data Center, v. 103, no. 13, 26 p.

National Oceanic and Atmospheric Administration, 2000, Climatological data annual summary, Missouri: Asheville, N.C., National Climate Data Center, v. 104, no. 13, 26 p.

National Oceanic and Atmospheric Administration, 2001, Climatological data annual summary, Missouri: Asheville, N.C., National Climate Data Center, v. 105, no. 13, 26 p.

National Oceanic and Atmospheric Administration, 2002, Climatological data annual summary, Missouri: Asheville, N.C., National Climate Data Center, v. 106, no. 13, 26 p.

National Oceanic and Atmospheric Administration, 2003, Climatological data annual summary, Missouri: Asheville, N.C., National Climate Data Center, v. 107, no. 13, 26 p.

National Oceanic and Atmospheric Administration, 2004, Climatological data annual summary, Missouri: Asheville, N.C., National Climate Data Center, v. 108, no. 13, 26 p.

Rimrock Geophysics, Inc., 1999, Seismic Refraction Interpretation Programs: Rimrock Geophysics, Inc., Lakewood, Colo. 
This page intentionally blank. 


\section{Retrospective Analysis of Land Cover at Overton Bottoms North, Missouri}

By Jeffrey D. Spooner and Keith F. Landgraf

Chapter 4 of

Science to Support Adaptive Habitat Management: Overton Bottoms

North Unit, Big Muddy National Fish and Wildlife Refuge, Missouri

In cooperation with the U.S. Fish and Wildlife Service

Scientific Investigations Report 2006-5086

U.S. Department of the Interior

U.S. Geological Survey 


\section{Contents}

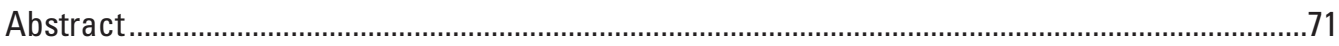

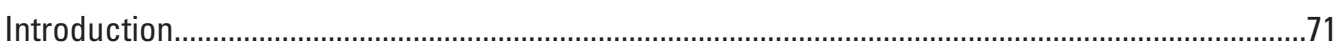

Purpose and Scope

Methods of Image Classification and Change Analysis ..............................................................73

Land-Cover Changes at Overton Bottoms ...............................................................................

Processes and Implications of Land-Cover Change at Overton Bottoms .......................................86

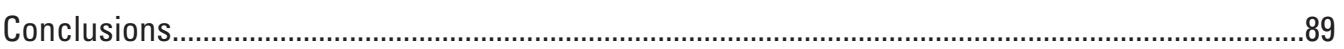

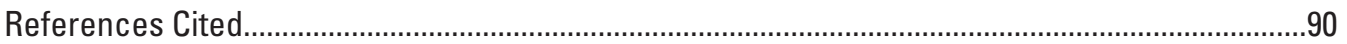

\section{Figures}

1-11. Maps showing-

1. Overton Bottoms North Unit and South Unit conservation areas ..............................72

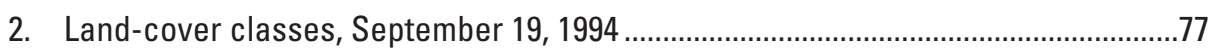

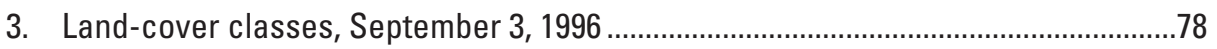

4. Change between September 19, 1994 and September 3, $1996 \ldots \ldots \ldots \ldots \ldots \ldots \ldots \ldots \ldots \ldots \ldots \ldots . . . . .19$

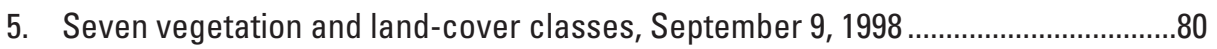

6. Change in land cover between September 3, 1996 and September 9, 1998 ..............81

7. Seven vegetation and land-cover classes, September $6,2000 \ldots \ldots \ldots \ldots \ldots \ldots \ldots \ldots \ldots \ldots . . . .82$

8. Change in land cover between September 9, 1998 and September 6, 2000 ..............83

9. Seven vegetation and land-cover classes, September 4, 2002 ............................84

10. Change in land cover between September 6, 2000 and September 4, 2002 .............85

11. Change in land cover between September 19, 1994 and September 4, 2002 ...........88

12. Patch characteristics of Overton Bottoms land-cover classes .......................................89

\section{Tables}

1. Landsat images...

2. Area totals and proportional abundance for each land-cover class per year .................75

3. Specific area total changes for each land-cover class per year ......................................76

4. Total perimeter length for each land-cover class per year ...............................................86 


\title{
Chapter 4 Retrospective Analysis of Land Cover at Overton Bottoms North, Missouri
}

\author{
By Jeffrey D. Spooner and Keith F. Landgraf
}

\section{Abstract}

We evaluated multi-year trends in land cover to assess how vegetation communities have been affected by hydrologic alteration of the Missouri River flood plain near Overton Bottoms, Missouri. Landsat multispectral satellite image data were used to map seven general classes of the vegetation and land cover on five different dates between September 1994 and September 2002. A supervised classification of the 2002 Landsat image was performed first, and then verified in the field in early September 2004. These observations, ancillary aerial photographs and Ikonos image data were used to produce land-cover maps from each of the four remaining Landsat images. Ten maps were produced: 5 showing the land-cover classes for each year, 4 showing the change in those classes from one date to the next, and 1 showing the overall changes in the classes between 1994 and 2002. Area and edge measurements and patch characteristics were calculated using the five land-cover maps.

The distribution and succession of land cover observed on Overton Bottoms from 1994 to 2002 are consistent with patterns at other sites along the Lower Missouri River. The distribution of cottonwood and willow trees on Overton Bottoms between 1994 and 2002 demonstrates the relation between the spatial and temporal distribution of flood plain land-cover classes and flood-plain landforms. While the total area of cottonwood and willow trees increased from 72 ha (hectares) in 1994 to 702 ha in 2002, the increase was not uniform across Overton Bottoms, but generally limited to areas on the flood plain that are adjacent to the river, unprotected by levees, and undisturbed by human activities. They also demonstrated a preference for surficial geologic units mapped as channel-fill allounits (Holbrook and others, this volume, chapter 2). This suggests a strong relation between surficial Lower Missouri River stratigraphy and the distribution of specific types of Lower Missouri River land cover.

\section{Introduction}

The construction of levees, bank revetments, and wing dikes along the Lower Missouri River has resulted in a substantial reduction in the quantity (spatial and temporal extent) and quality (diversity) of terrestrial and aquatic habitats (Funk and Robinson, 1974; National Research Council, 2002). Efforts during the late 1990's to rehabilitate the river corridor have included modifying the existing channel control structures, rehabilitating flood-plain wetlands, and constructing side channels (Galat and others, 1996; Chapman and others, 2004; Jacobson and others, 2004). The success of these and other habitat rehabilitation and restoration efforts along the Lower Missouri River is dependent on an appreciation for the complexity of terrestrial riverine ecosystems. Questions regarding the interdependence of flood-plain processes and ecosystem structure and function are in the forefront of ecological research interests. The answers to these questions are important to natural resource managers practicing adaptive management along the Lower Missouri River.

A critical component of flood-plain ecology is the spatial and temporal distribution of vegetation. Flood plains typically are dynamic surfaces that are continuously reshaped by erosion and deposition. These processes play an important role in the distribution of flood-plain vegetation within space and time (Hupp and Osterkamp, 1996; Kalliola and Puhakka, 1998; Robertson and Augspurger, 1999). These spatial and temporal patterns of flood-plain vegetation are particularly complex along the Lower Missouri River where recent conversion of agricultural land to conservation purposes has resulted in rapid changes.

Much of the flood plain of the Lower Missouri River, including Overton Bottoms (fig. 1), has been cleared for agriculture since settlement in the early 1800's. The surface has been reworked by plows, row crops have replaced natural 


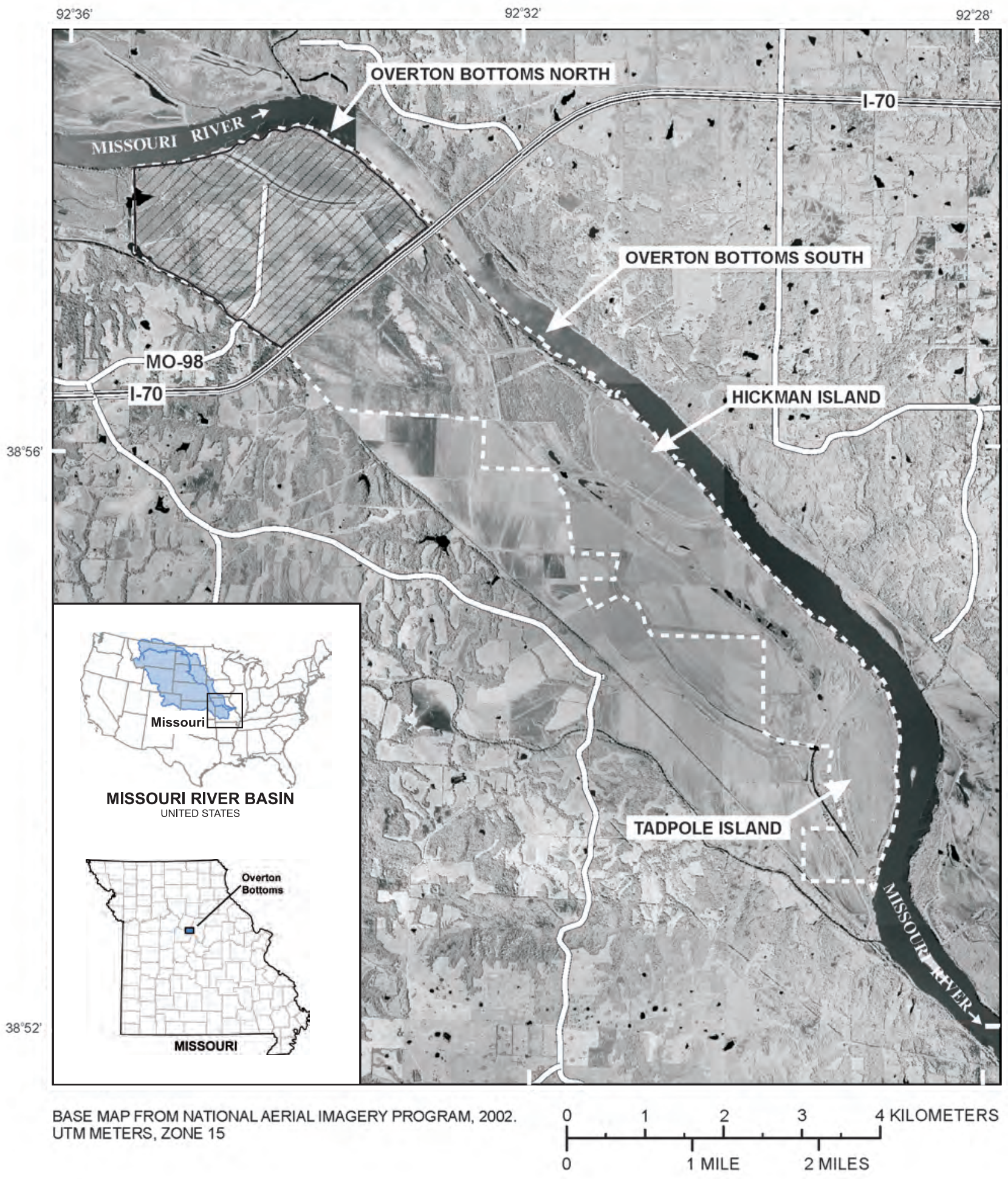

Figure 1. Location of Overton Bottoms North Unit and South Unit conservation areas. 
vegetation, and construction of levees has disconnected the flood plain from the river. These modifications effectively suppressed or substantially altered natural flood-plain biophysical processes. Since acquiring Overton Bottoms in the mid 1990's, managers within the U.S. Army Corps of Engineers (USACE), U.S. Fish and Wildlife Service (USFWS), and the Missouri Department of Conservation (MDC) have allowed much of Overton Bottoms to return to more natural conditions. Levee failures associated with the flood of 1993 were not repaired, and a side-channel chute was constructed in 2000 (Jacobson, this volume, chapter 1). Consequently, much of Overton Bottoms has been subjected to seasonal flooding, and naturally occurring vegetation now occurs over much of the area, especially Overton Bottoms North Unit (fig. 1).

Remotely sensed imagery, which includes multispectral digital satellite image data and aerial photographs, are an ideal source for a retrospective analysis of land-cover changes on the Lower Missouri River flood plain. Nearly continuous multispectral satellite image data acquired since 1972 are available. Less regular aerial photographs acquired since the late 1930's also are available. These two types of data and associated analytical techniques provide an opportunity to map land cover over a large area like the Lower Missouri River flood plain, or at a specific area like Overton Bottoms. Two simple comparisons can be used to evaluate land-cover change on the flood plain: the measured increase or decrease in the total area of a specific land-cover class from one date to another, and the measured changes in their spatial patterns.

Area and edge are two fundamental measures of terrestrial landscapes. They typically are used to help characterize patterns of land cover. One of the simplest and most useful measures of a landscape is the total area of particular landcover type (or its proportional abundance across a specific place), and whether it increases or decreases with time. The total area of a particular land-cover type can be easily calculated, especially when the source of the measurement is rasterimage data. Once individual cells in the image are classified, the area of a particular class is calculated by multiplying the total number of cells by the area of a single cell. Changes with time can be determined by arithmetically comparing area measurements derived from one image to those derived from another.

Edges also are an important feature of most terrestrial landscapes. Their presence, complexity, and distribution provide an indication of the structure, abundance, and variability of habitats across a particular landscape. Although not as easily calculated as area, the total length of the edge of a land-cover type provides a useful landscape measure.

\section{Purpose and Scope}

The purpose of this report is to document the effects of altered hydrology and land use at Overton Bottoms on broad-scale characteristics of vegetation communities. The areal extent is the valley-bottom land within the boundaries of the Overton Bottoms North Unit, a part of the Big Muddy National Fish and Wildlife Refuge (managed by the USFWS) and the Overton Bottoms South Unit (managed by MDC). The time period under consideration is from 1994 to 2002. This period covers the adjustment of Overton Bottoms vegetation communities to breached levees and side-channel chute construction after the 1993 flood.

\section{Methods of Image Classification and Change Analysis}

A hybrid method of land-cover change analysis developed by Loveland and others (2002) was used to estimate the rates of land-cover change on Overton Bottoms since the flood of 1993. This method combines supervised image classification and visual interpretation of Landsat multispectral satellite image data using aerial photographs, additional high resolution satellite imagery, and field observations. Seven general classes of land cover were defined and mapped for each of 5 different dates between September 1994 and September 2002. The seven classes included water, bare ground, weeds/grasses/ forbs, cottonwoods/willows, mature trees, agricultural fields, and roads.

Five Landsat images, three digital aerial orthophotographs and two Ikonos multispectral images were acquired. The Landsat data have an early September acquisition date (table 1). Four images (1994, 1996, 1998 and 2002) are Landsat 5 Thematic Mapper (TM) data. A suitable Landsat 5 TM image for 2000 was not available, so a Landsat 7 image was used. Landsat 7 carries an improved TM sensor called the Enhanced Thematic Mapper (ETM+) that records the same seven bands as the TM sensor aboard Landsat 5, plus an additional sensor that records high resolution panchromatic data. The spatial resolution of bands one through five and seven of both the TM and ETM+ data is $30 \mathrm{~m}$ (meters), with a positional accuracy of $+/-15 \mathrm{~m}$. Although they are less than $30 \mathrm{~m}$ wide, roads could be mapped because of their distinct shape, distinct spectral signature, and high contrast with the landcover classes that they cross. The ancillary data that were used included digital aerial orthophotographs and Ikonos multispectral and panchromatic image data. The orthophotographs were acquired in 1995, 2000, and 2003. The 1995 data are black and white, the 2000 data are natural color, and the 2003 data are color infrared. The Ikonos data were acquired in 2000.

Table 1. Landsat images.

\begin{tabular}{lcc}
\hline \multicolumn{1}{c}{ Sensor } & Scene ID & Acquisition Date \\
\hline TM-5 & 5025033009425710 & September 19, 1994 \\
TM-5 & 5025033009624710 & September 3, 1996 \\
TM-5 & 5025033009825210 & September 9, 1998 \\
ETM+ & 7025033000025050 & September 6, 2000 \\
TM-5 & 5025033000224710 & September 4, 2002 \\
\hline
\end{tabular}


A template was used to clip each of the five Landsat images to the extent of the Overton Bottoms conservation areas to limit the amount of processing and the extent of the analysis. A general center line of the Missouri River formed one side of the template, and a combination of the valley wall and the boundary of the Overton Bottoms conservation area formed the other. Training sets were defined for each of the seven classes by visually interpreting the TM scene, the orthophotographs, and the Ikonos imagery. A supervised classification of the 2002 TM scene was completed using a maximum likelihood classifier. The classification was verified in the field in September 2004 and edited by the analyst using the ancillary photographs and images. The overall thematic accuracy of the classification was 92.8 percent. The thematic accuracy was determined by following the procedures developed for the U.S. Geological Survey (USGS)/National Park Service Vegetation Mapping Program (USGS, 2005).

Land-cover maps for each of the four remaining dates of Landsat imagery were produced by visually interpreting each Landsat scene, supplemented by the ancillary orthophotographs and imagery. For example, the September 2000 landcover data were collected by visually comparing the September 2002 land-cover map to the September 2000 Landsat scene and looking for land-cover changes that had occurred between September 2000 and September 2002. Any identified changes in land cover were manually digitized on-screen to produce a September 2000 land-cover map. The resulting land-cover map was then used as a starting point to interpret the 1998 TM scene, and so forth. Land-cover change estimates were calculated by comparing the area and the total perimeter length of each land-cover class from one year to the next. Patch characteristics were derived from the land-cover maps using the FRAGSTATS program (McGarigal and Marks, 1995). ${ }^{1}$

\section{Land-Cover Changes at Overton Bottoms}

Ten data sets were produced using the Landsat TM images: 5 maps showing the land cover for each year, 4 maps showing the change in those classes from one date to the next, and 1 map showing the overall changes in land cover between 1994 and 2002. The area of each of the classes is summarized by year in table 2. More detailed information about the total area of change from one date to the next, and from the earliest to the latest date is provided in table 3 . The total length of the perimeter, or edge of each of the classes for each year is summarized in table 4.

The map of Overton Bottoms that was produced using the September 19, 1994 TM data is shown in figure 2. The total land area in conservation areas at Overton Bottoms is 2,017 ha. The total area of the image, which includes a portion of

\footnotetext{
${ }^{1}$ Any use of trade, product, or firm names is for descriptive purposes only and does not imply endorsement by the U.S. Government.
}

the Missouri River channel, is 2,348 ha. The most abundant land-cover class in September 1994 was weeds/forbs/grasses, followed by agricultural fields (table 2). Before 1993, most of Overton Bottoms was being farmed, but by 1994, farming had been abandoned over large areas. Some areas, mostly in the northwest (Overton Bottoms North Unit), were covered with sand. A particularly large sand area extends away from Interstate 70 (I-70) towards the southeast; this deposit is a splay produced from scour under I-70 during the 1993 flood. The mature trees-community class is limited to the riparian corridor along the river, a large area just upstream of Hickman Island and an area adjacent to Tadpole Island extending upstream along an abandoned side channel. Most of the area classified as mature tree community is on the river side of the levees. The water class is limited to the main channel of the Missouri River, the abandoned side channel at Tadpole Island, and several flood-plain depressions. The most notable of these is the scour bisected by I-70 just west of the Missouri River. The cottonwoods/willows class is limited to very small areas, and other than roads, represents the least abundant land-cover class in 1994.

The map of Overton Bottoms that was produced using the September 3, 1996 TM data is shown in figure 3. The most notable difference between this map and the one generated using the 1994 TM data is the increased area of the cottonwoods/willows class. This class increased from 72 ha in 1994 to 248 ha in 1996. The total area of cottonwoods/willows in 1996 included 10 ha that had been bare ground, 162 ha that had been weeds/forbs/grasses, and 4 ha that had been agricultural fields in 1994 (table 3). A map of the areas where the land cover had changed between 1994 and 1996 is shown in figure 4. Areas where the land-cover classes did not change are blank (gray-scale background image shows through); areas where the land cover did change are shown in the color of the land-cover class that they became. This figure clearly shows large areas where the land-cover class had changed to cottonwoods/willows. The largest contiguous areas of cottonwoods/willows are Hickman Island, located near the midpoint of Overton Bottoms, and Tadpole Island located at the southeastern end of Overton Bottoms. Both areas are delimited by abandoned river channels. A third, smaller area occupied by discontinuous polygons of cottonwoods/willows is on an unnamed island on the northeastern part of Overton Bottoms. The fourth area occupied by cottonwoods/willows is an area of small discontinuous polygons in the northwestern part of Overton Bottoms.

The weeds/forbs/grasses class continued to be the most abundant land-cover class in September 1996 (table 2). Small discontinuous areas of bare ground or agricultural fields became weeds/forbs/grasses (fig. 4). These areas include a total of 38 ha that had been bare ground, and 24 ha that had been agricultural fields (table 3). Flooding in 1995 resulted in additional damage to agricultural land on Overton Bottoms. It also was during this time that ownership of Overton Bottoms was changing from private to public through the willing sale by private land owners to the USACE, MDC, and USFWS. 
The total area of water, mature trees, and roads remained unchanged from September 1994 to September 1996.

The map of Overton Bottoms that was produced using the September 9, 1998 TM data shows large continuous areas of cottonwoods/willows on the northwest, east, and southeast parts of Overton Bottoms (fig. 5). The total area of cottonwoods/willows increased from 248 ha in September 1996, to 487 ha in September 1998 (table 2). The increased area included 16 ha that had been bare ground and 223 ha that had been weeds/forbs/grasses (table 3). Substantial change from bare ground and weeds/forbs/grasses to cottonwoods/willows can be seen along the northwestern and southeastern margins of Overton Bottoms by comparing figure 3 and figure 5. A map of the change from one land-cover class to another is shown in figure 6. In addition to the large continuous areas that became cottonwoods/willows between September 1996 and September 1998, it is interesting to note small discontinuous areas on the northwestern part of the bottoms west of Missouri Route 98 that changed to cottonwoods/willows during the same time period. Equally interesting is the change that occurred along the western and southern margin of the large area of bare ground southeast of I-70. This area changed from bare ground to a patchwork of weeds/forbs/grasses and cottonwoods/willows. The northern and eastern margin of the same area changed from bare ground to weeds/forbs/grasses (fig. 6). Elsewhere, 8 ha of agricultural fields changed to weeds/forbs/ grasses (table 3 ). The total areas of water, roads, and mature trees remained unchanged.

The map of Overton Bottoms that was produced using the September 6, 2000 ETM+ data shows additional areas of cottonwoods/willows (fig. 7). The total area of cottonwoods/willows increased from 487 ha to 614 ha (table 2). The majority of change occurred on the northern end of Overton Bottoms and along the margin of the large area of bare ground southeast of I-70 (fig. 7). The total area of cottonwoods/willows also increased on Tadpole Island, and a new area of bare ground can be seen on the northern end of Overton Bottoms (figs. 7 and 8). This new area of bare ground is a side channel that was being constructed by the USACE in 2000. The con- struction activity increased the total area of bare ground from 66 ha in September 1998 to 90 ha in September 2000 (table 3). In addition, a new road constructed on the northwest part of the bottoms west of Missouri Route 98 is shown on figures 7 and 8. This new road increased the total area of roads from 51 ha in September 1998 to 61 ha in September 2000. The total area of water increased by 1 ha because a small floodplain depression on the northwestern part of the bottoms was inundated when the ETM+ data were acquired. The construction of the side-channel chute by the USACE on the Overton Bottoms North Unit also reduced the total area of mature trees by 2 ha, which became bare ground or weeds/forbs/grasses. The weeds/forbs/grasses class continued to be the most abundant land-cover class in September 2000 (table 2). A large area near the central part of Overton Bottoms that was classified as agricultural fields in September 1998 changed to weeds/forbs/ grasses in September 2000 (fig. 8). Similarly, 6 ha of bare ground, 2 ha of cottonwoods/willows, and 1 ha of mature trees changed to weeds/forbs/grasses between September 1998 and September 2000 (table 3).

The map of Overton Bottoms that was produced using the September 4, 2002 TM data (fig. 9) shows continued changes in land cover compared to the map of land cover in 2000 (fig. 7). A particularly interesting area is the long linear area of bare ground that borders agricultural fields through the central part of Overton Bottoms shown on figures 9 and 10. This area of bare ground is the result of the construction associated with the relocation of a levee by the USACE. Similarly, the area of bare ground shown in figures 7 and 8 that was cleared to construct the side-channel chute on Overton Bottoms North Unit changed to weeds/grasses/forbs. A second notable change is the increased area of cottonwoods/willows on the northern end of Overton Bottoms North Unit, and on Hickman and Tadpole Islands. There also are more cottonwoods/willows areas replacing weeds/forbs/grasses along the western margin of the bare ground area to the southeast of I-70 and occupying narrow linear areas along the western side of the northwestern part of the bottoms. Overall, the area of cottonwoods/willows increased from 614 ha in September 2000 to 702 ha in 2002

Table 2. Area totals and proportional abundance for each land-cover class by year.

[ha, hectare; \%, percent]

\begin{tabular}{rrrrrrrrrrr}
\hline Land-cover Class & \multicolumn{2}{c}{$\mathbf{1 9 9 4}$} & \multicolumn{2}{c}{$\mathbf{1 9 9 6}$} & \multicolumn{2}{c}{$\mathbf{1 9 9 8}$} & \multicolumn{2}{c}{$\mathbf{2 0 0 0}$} & \multicolumn{2}{c}{$\mathbf{2 0 0 2}$} \\
& (ha) & (\%) & (ha) & (\%) & (ha) & (\%) & (ha) & (\%) & (ha) & (\%) \\
\hline Water & 112 & 5 & 112 & 5 & 112 & 5 & 113 & 5 & 119 & 5 \\
Bare ground & 139 & 6 & 99 & 4 & 66 & 3 & 90 & 4 & 114 & 5 \\
Weeds/forbs/grasses & 1,276 & 54 & 1,167 & 50 & 969 & 41 & 907 & 38 & 854 & 36 \\
Cottonwoods/willows & 72 & 3 & 248 & 10 & 487 & 21 & 614 & 26 & 702 & 30 \\
Mature trees & 228 & 10 & 228 & 10 & 228 & 10 & 226 & 10 & 223 & 9 \\
Agricultural fields & 470 & 20 & 443 & 19 & 435 & 18 & 337 & 14 & 275 & 12 \\
Roads & 51 & 2 & 51 & 2 & 51 & 2 & 61 & 3 & 61 & 3 \\
Total & 2,348 & & 2,348 & & 2,348 & & 2,384 & & 2,348 \\
\hline
\end{tabular}


Table 3. Specific area total changes for each land-cover class per year on Overton Bottoms North. The columns list the land-cover class area total for one year; the rows list the land-cover class and area total for the previous year. For example, the total area of bare ground was 139 ha in 1994. By 1996, 90 ha remained bare ground, but 38 ha became weeds/forbs/grasses, 10 ha became cottonwoods/ willows, and 1 ha became agricultural fields.

\begin{tabular}{|c|c|c|c|c|c|c|c|c|}
\hline & Water & $\begin{array}{l}\text { Bare } \\
\text { Ground }\end{array}$ & $\begin{array}{c}\text { Weeds/forbs/ } \\
\text { grasses }\end{array}$ & $\begin{array}{c}\text { Cottonwoods/ } \\
\text { willows }\end{array}$ & $\begin{array}{c}\text { Mature } \\
\text { trees }\end{array}$ & $\begin{array}{l}\text { Agricultural } \\
\text { fields }\end{array}$ & Roads & Totals \\
\hline & & & & 1996 & & & & 1994 \\
\hline Water (1994) & 112 & 0 & 0 & 0 & 0 & 0 & 0 & 112 \\
\hline Bare ground (1994) & 0 & 90 & 38 & 10 & 0 & 1 & 0 & 139 \\
\hline Weeds/forbs/grasses (1994) & 0 & 9 & 1105 & 162 & 0 & 0 & 0 & 1,276 \\
\hline Cottonwoods/willows (1994) & 0 & 0 & 0 & 72 & 0 & 0 & 0 & 72 \\
\hline Mature trees (1994) & 0 & 0 & 0 & 0 & 228 & 0 & 0 & 228 \\
\hline Agricultural fields (1994) & 0 & 0 & 24 & 4 & 0 & 442 & 0 & 470 \\
\hline Roads (1994) & 0 & 0 & 0 & 0 & 0 & 0 & 51 & 51 \\
\hline \multirow[t]{2}{*}{ Total (1996) } & 112 & 99 & 1,167 & 248 & 228 & 443 & 51 & 2,348 \\
\hline & & & & 1998 & & & & 1996 \\
\hline Water (1996) & 112 & 0 & 0 & 0 & 0 & 0 & 0 & 112 \\
\hline Bare ground (1996) & 0 & 56 & 27 & 16 & 0 & 0 & 0 & 99 \\
\hline Weeds/forbs/grasses (1996) & 0 & 10 & 934 & 223 & 0 & 0 & 0 & 1167 \\
\hline Cottonwoods/willows (1996) & 0 & 0 & 0 & 248 & 0 & 0 & 0 & 248 \\
\hline Mature trees (1996) & 0 & 0 & 0 & 0 & 228 & 0 & 0 & 228 \\
\hline Agricultural fields (1996) & 0 & 0 & 8 & 0 & 0 & 435 & 0 & 443 \\
\hline Roads (1996) & 0 & 0 & 0 & 0 & 0 & 0 & 51 & 51 \\
\hline \multirow[t]{2}{*}{ Total (1998) } & 112 & 66 & 969 & 487 & 228 & 435 & 51 & 2,348 \\
\hline & & & & 2000 & & & & 1998 \\
\hline Water (1998) & 112 & 0 & 0 & 0 & 0 & 0 & 0 & 112 \\
\hline Bare ground (1998) & 1 & 54 & 6 & 5 & 0 & 0 & 0 & 66 \\
\hline Weeds/forbs/grasses (1998) & 0 & 24 & 801 & 135 & 0 & 0 & 9 & 969 \\
\hline Cottonwoods/willows (1998) & 0 & 11 & 2 & 474 & 0 & 0 & 0 & 487 \\
\hline Mature trees (1998) & 0 & 1 & 1 & 0 & 226 & 0 & 0 & 228 \\
\hline Agricultural fields (1998) & 0 & 0 & 98 & 0 & 0 & 337 & 0 & 435 \\
\hline Roads (1998) & 0 & 0 & 0 & 0 & 0 & 0 & 51 & 51 \\
\hline \multirow[t]{2}{*}{ Total (2000) } & 113 & 90 & 907 & 614 & 226 & 337 & 61 & 2,348 \\
\hline & & & & 2002 & & & & 2000 \\
\hline Water (2000) & 113 & 0 & 0 & 0 & 0 & 0 & 0 & 113 \\
\hline Bare ground (2000) & 0 & 42 & 42 & 6 & 0 & 0 & 0 & 90 \\
\hline Weeds/forbs/grasses (2000) & 3 & 39 & 779 & 83 & 0 & 3 & 0 & 907 \\
\hline Cottonwoods/willows (2000) & 0 & 1 & 2 & 611 & 0 & 0 & 0 & 614 \\
\hline Mature trees (2000) & 0 & 3 & 0 & 0 & 223 & 0 & 0 & 226 \\
\hline Agricultural fields (2000) & 3 & 29 & 31 & 2 & 0 & 272 & 0 & 337 \\
\hline Roads (2000) & 0 & 0 & 0 & 0 & 0 & 0 & 61 & 61 \\
\hline \multirow[t]{2}{*}{ Total (2002) } & 119 & 114 & 854 & 702 & 223 & 275 & 61 & 2,348 \\
\hline & & & & 2002 & & & & 1994 \\
\hline Water (1994) & 112 & 0 & 0 & 0 & 0 & 0 & 0 & 112 \\
\hline Bare ground (1994) & 0 & 32 & 29 & 77 & 0 & 0 & 1 & 139 \\
\hline Weeds/forbs/grasses (1994) & 2 & 22 & 709 & 531 & 0 & 3 & 9 & 1,276 \\
\hline Cottonwoods/willows (1994) & 0 & 0 & 0 & 72 & 0 & 0 & 0 & 72 \\
\hline Mature trees (1994) & 0 & 3 & 1 & 1 & 223 & 0 & 0 & 228 \\
\hline Agricultural fields (1994) & 4 & 56 & 116 & 21 & 0 & 273 & 0 & 470 \\
\hline Roads (1994) & 0 & 0 & 0 & 0 & 0 & 0 & 61 & 51 \\
\hline Total (2002) & 119 & 114 & 854 & 702 & 223 & 275 & 61 & 2,348 \\
\hline
\end{tabular}




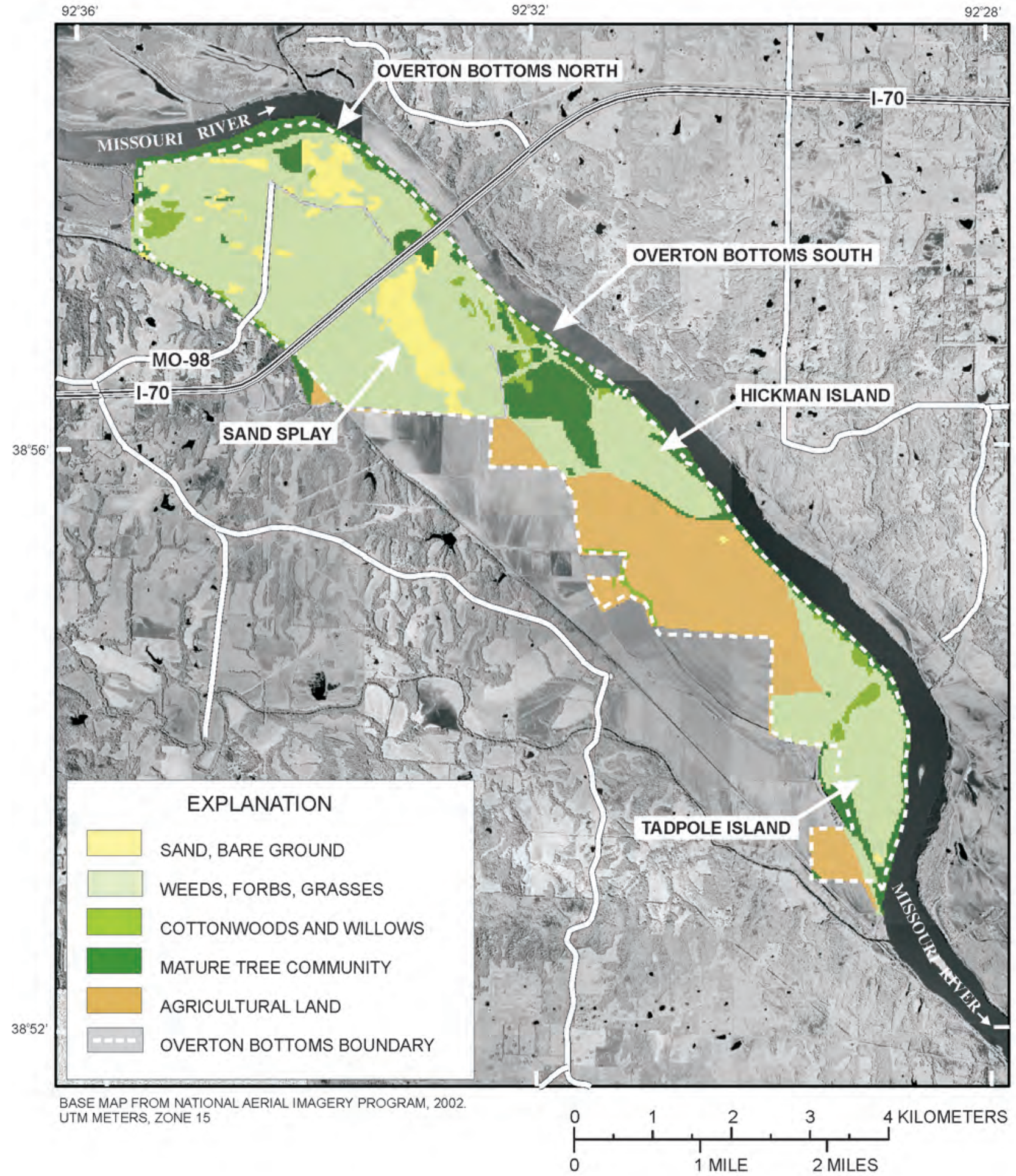

Figure 2. Overton Bottoms showing land-cover classes derived from Landsat TM-5 data acquired September 19, 1994. 


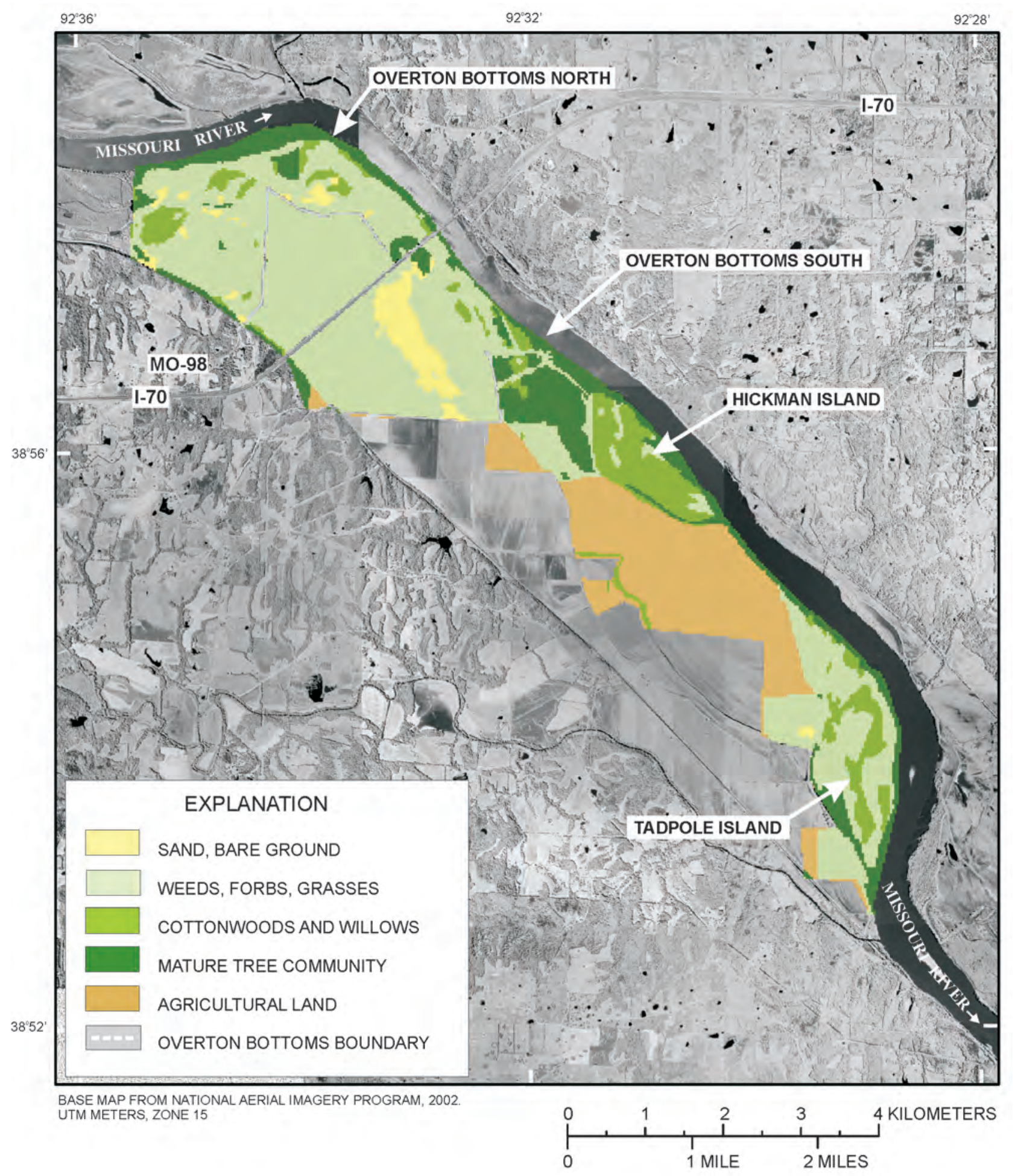

Figure 3. Overton Bottoms showing land-cover classes derived from Landsat TM-5 data acquired September 3, 1996. 


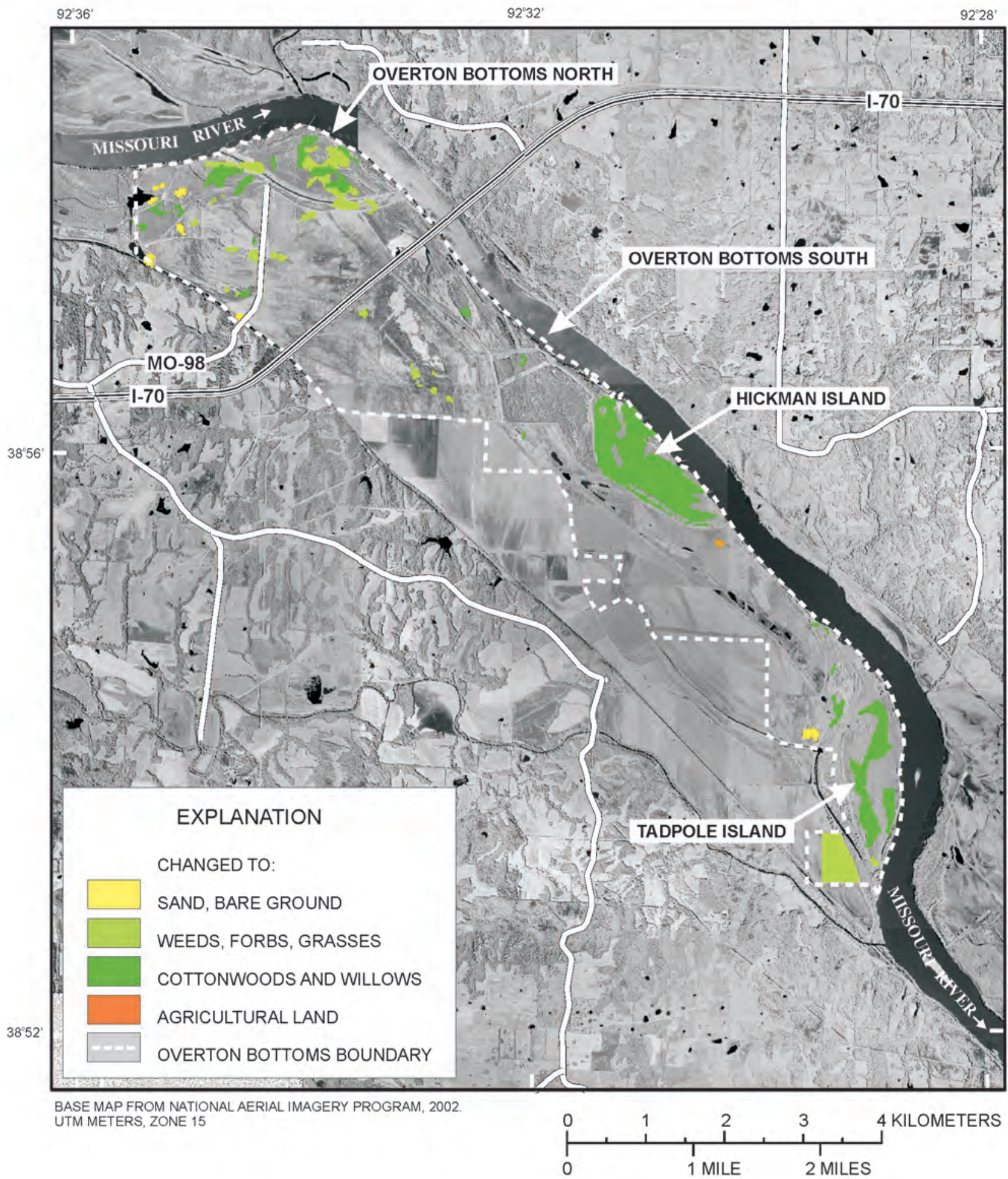

Figure 4. Overton Bottoms showing the change in vegetation and land-cover classes that occurred between September 19, 1994 and September 3, 1996. Areas where the vegetation and land-cover classes did not change are uncolored. Areas where they did change are shown in the color of the vegetation and land-cover class that they became. 


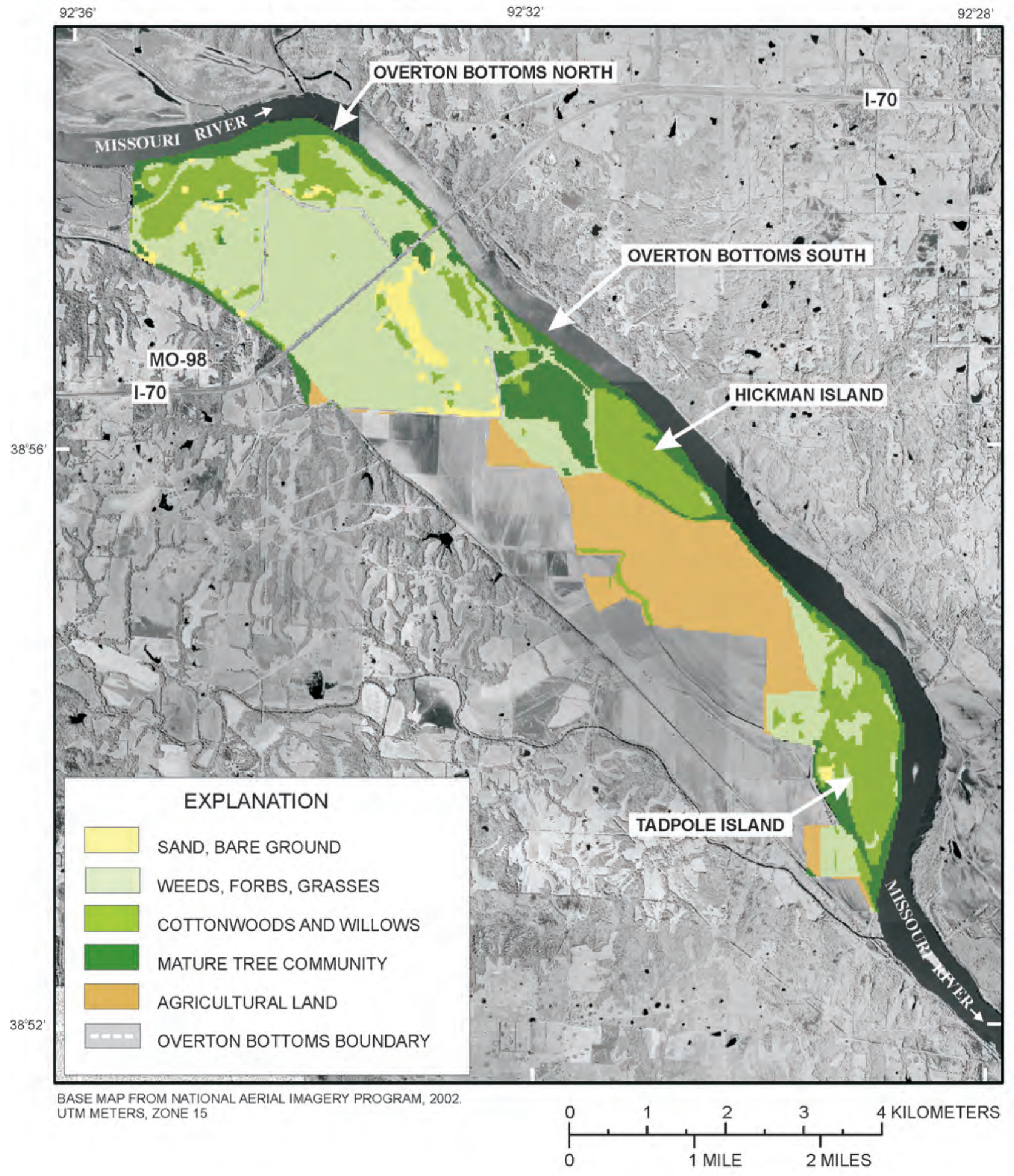

Figure 5. Overton Bottoms showing seven vegetation and land-cover classes derived from TM-5 data acquired September 9, 1998. 


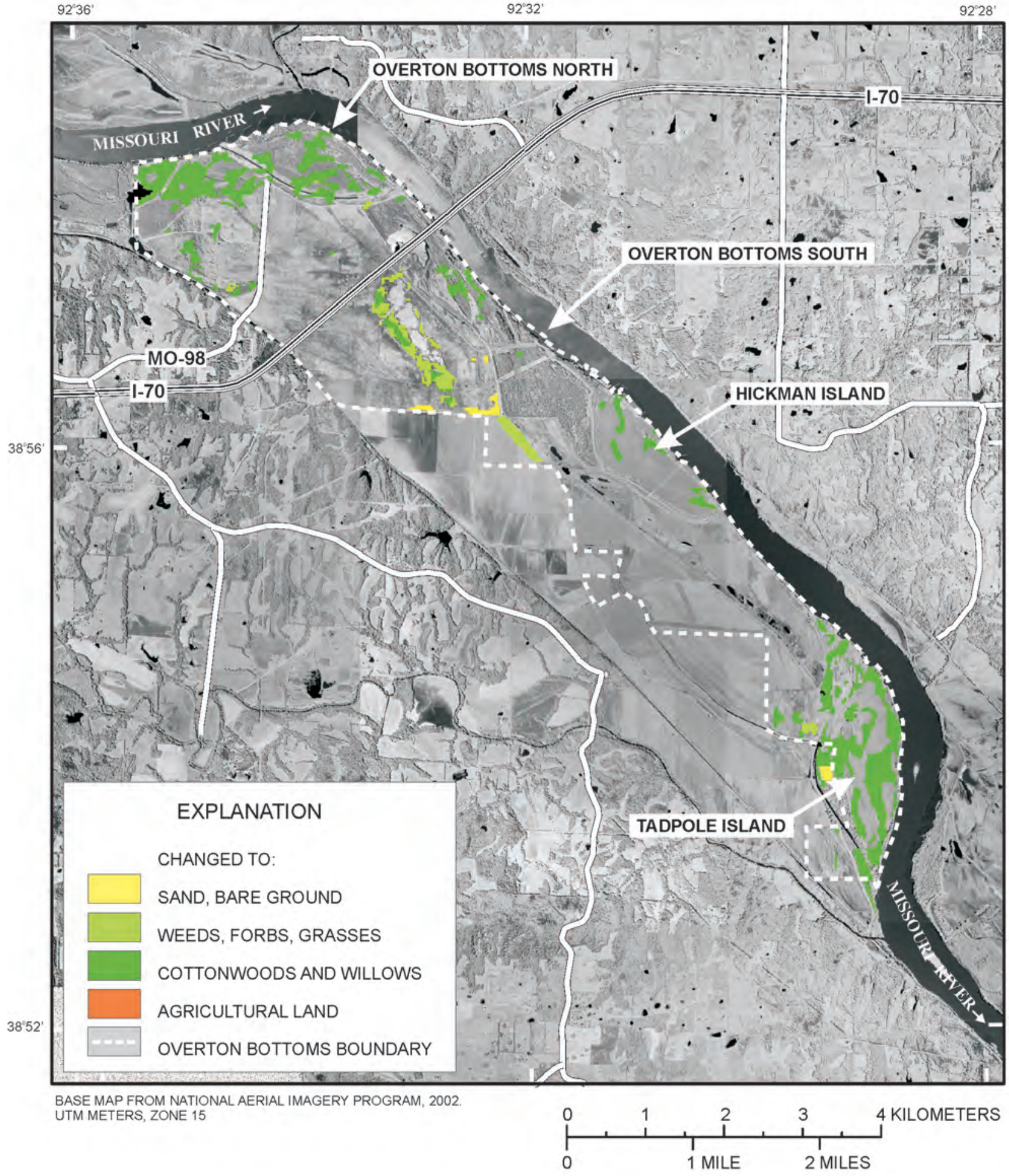

Figure 6. Overton Bottoms showing the change in vegetation and land-cover classes that occurred between September 3, 1996 and September 9, 1998. Areas where the vegetation and land-cover classes did not change are uncolored. Areas where they did change are shown in the color of the vegetation and land-cover class that they became. 


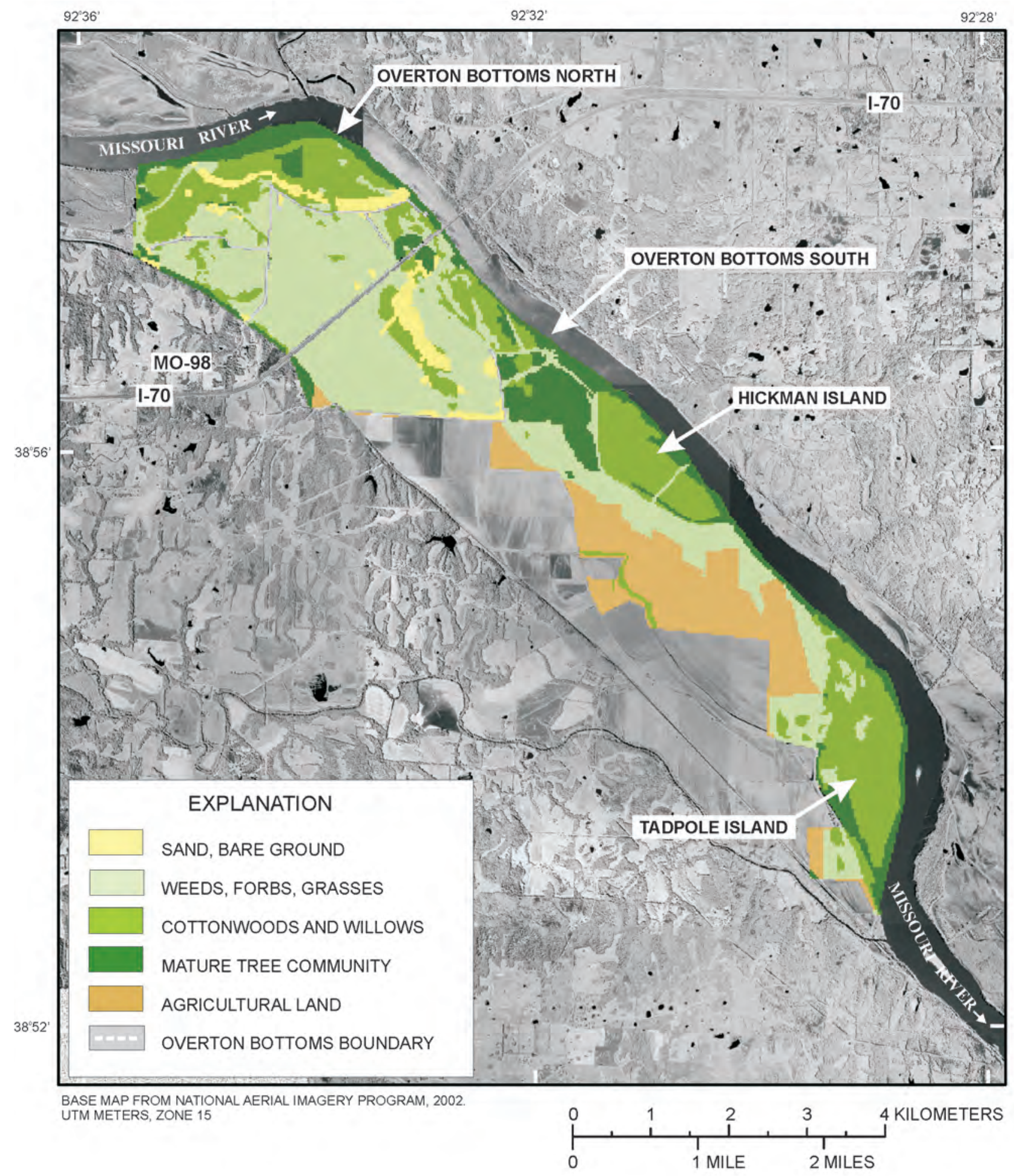

Figure 7. Overton Bottoms showing seven vegetation and land-cover classes derived from ETM+ data acquired September 6, 2000. 


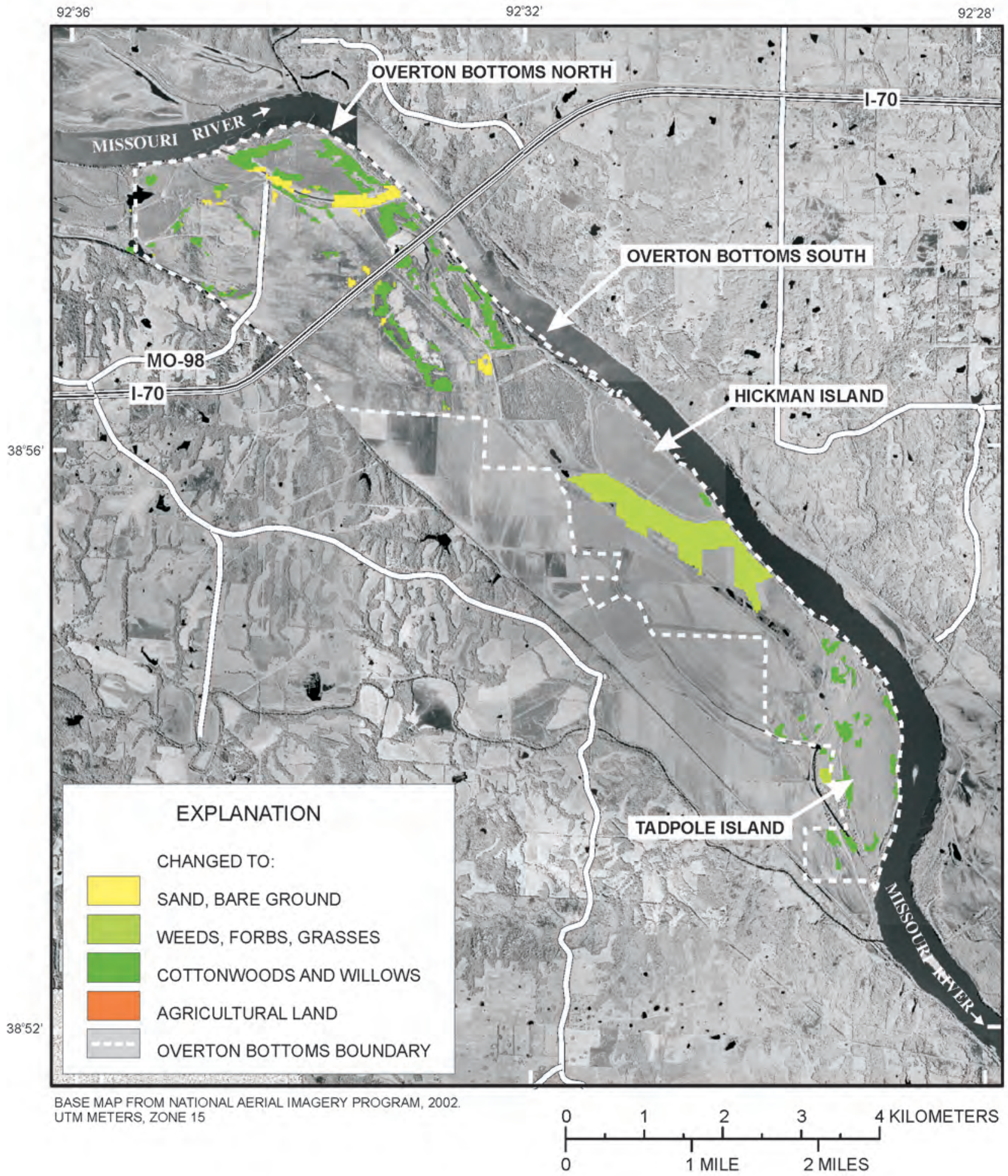

Figure 8. Overton Bottoms showing the change in vegetation and land-cover classes that occurred between September 9, 1998 and September 6, 2000. Areas where the vegetation and land-cover classes did not change are uncolored. Areas where they did change are shown in the color of the vegetation and land-cover class that they became. 


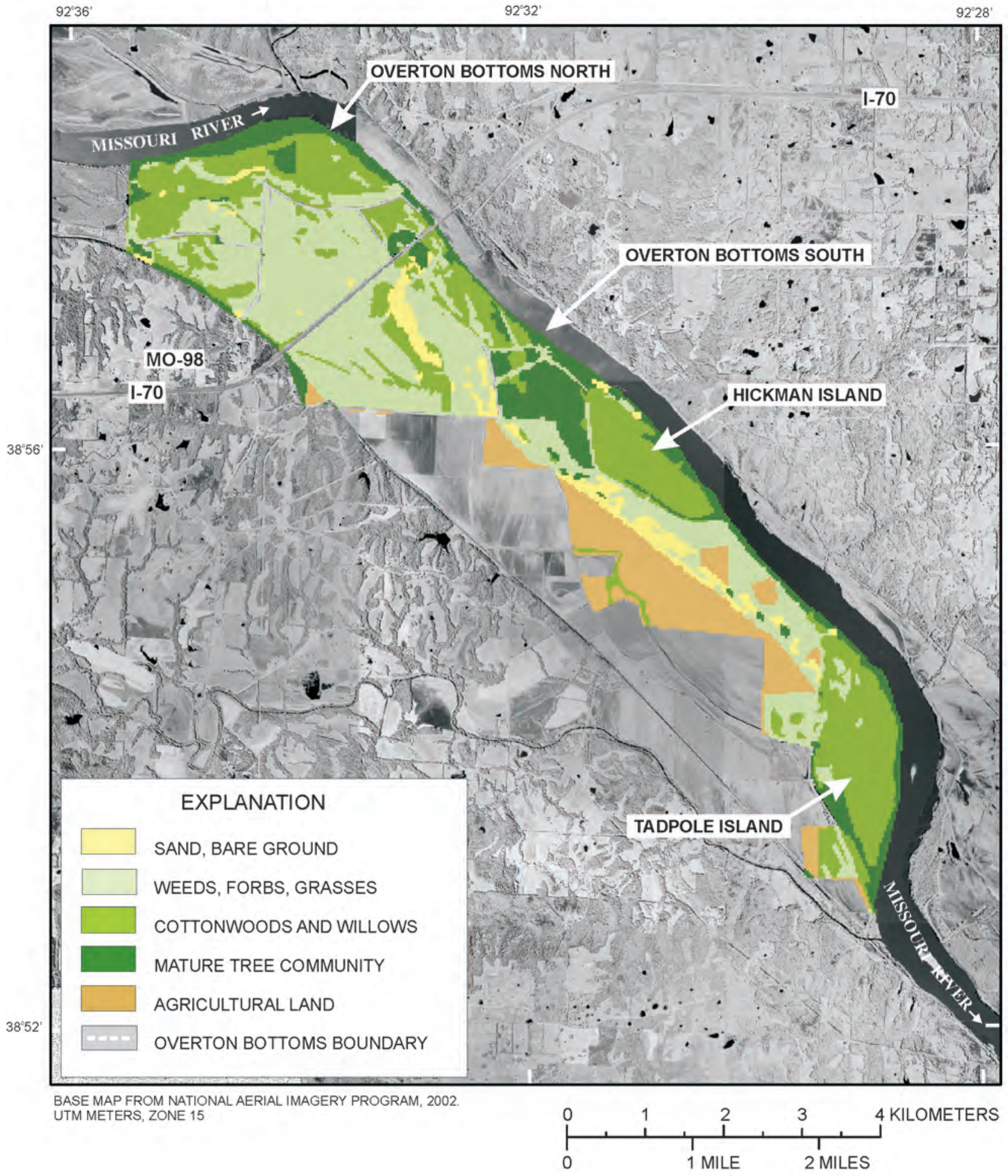

Figure 9. Overton Bottoms showing seven vegetation and land-cover classes derived from TM-5 data acquired September 4, 2002. 


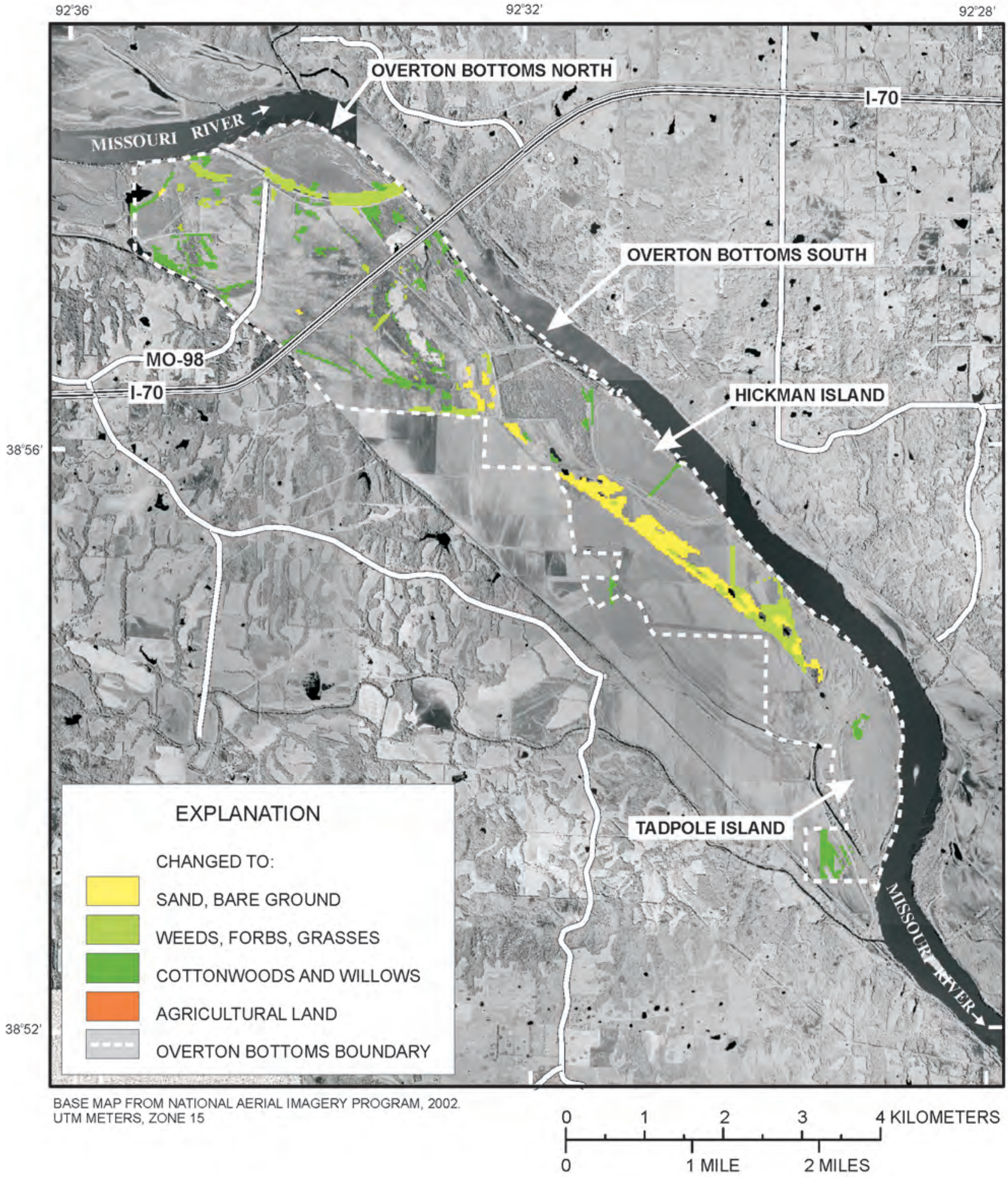

Figure 10. Overton Bottoms showing the change in vegetation and land-cover classes that occurred between September 6, 2000 and September 4, 2002. Areas where the vegetation and land-cover classes did not change are uncolored. Areas where they did change are shown in the color of the vegetation and land-cover class that they became. 
(table 2). Of the total, 6 ha had been bare ground, 83 ha had been weeds/forbs/grasses, and 2 ha had been agricultural fields in September 2000 (table 3).

The total area of water increased 6 ha from 113 ha in September 2000 to 119 ha in September 2002. This change occurred within the area on Overton Bottoms where the levee had been relocated. Weeds/forbs/grasses continued to be the most abundant land-cover class in September 2002 (table 2). Of the total, 42 ha had been bare ground, 2 ha had been cottonwoods/willows, and 31 ha had been agricultural fields in September 2000 (table 3). The total area of mature trees decreased from 226 ha in 2000 to 223 ha in 2002, and the total area of agricultural fields was reduced from 337 ha in 2000 to 275 ha in 2002. Changes in the total area of water, weeds/forbs/ grasses, mature trees, and agricultural fields were all associated with the relocation of the levee.

The most notable change in land cover that occurred on Overton Bottoms between September 1994 and September 2002 was the increase in the total area of cottonwoods/willows from 72 ha in 1994 to 702 ha in 2002 (table 3; figs. 11, 12A, $12 C$ ). Most of this change occurred on the northern part of Overton Bottoms, and on Hickman and Tadpole Islands (fig. 11). Between September 1994 and September 2002, 77 ha of bare ground, 531 ha of weeds/forbs/grasses, 1 ha of mature trees, and 21 ha of agricultural fields changed to cottonwoods/ willows (table 3). Bottomland hardwood trees have also been planted in parts of Overton Bottom North and South, but these plantations were not developed sufficiently to be identified on the multispectral imagery.

The second major change is the reduction of agricultural fields from 470 ha in 1994 to 275 ha in 2002 (table 2). Most of this change occurred between 1998 and 2000 when 98 ha were converted to weeds/forbs/grasses, and between 2000 and 2002 in association with the relocation of the levee. The third most notable change occurred with weeds/forbs/grasses. The total area of this class decreased from 1276 ha in 1994, to 855 ha in 2002. This change occurred across the entire bottom, with 531 ha becoming cottonwoods/willows, and 22 ha becoming bare ground, the latter of which was largely because of the construction associated with the relocation of the levee by the USACE (table 3).

Changes in perimeter-or edge length-have accompanied changes in area between 1994 and 2002 (table 4; fig. 12B). Overall, the total length of the perimeters increased from $334,980 \mathrm{~m}$ in 1994 to $475,800 \mathrm{~m}$ in 2002 . As with area, the length of the perimeters of weeds/forbs/grasses and cottonwoods/willows changed the most. Both increased, although the cottonwoods/willows changed more. The total length of the perimeter of water increased slightly in 2000 and again in 2002. The total perimeter of roads also increased slightly in 2000 and again in 2002, whereas the total perimeter of mature trees decreased slightly in 2000 and again in 2002.

\section{Processes and Implications of Land- Cover Change at Overton Bottoms}

The flood plain of the Lower Missouri River is a dynamic landform that has been shaped by a variety of natural processes and human activities. Complex interactions among these processes and activities have affected the structure, dynamics, and composition of its habitats. In the absence of human activities, flood-plain vegetation classes will occupy sites suitable to their class-specific requirements. The distribution and succession of vegetative land cover observed on Overton Bottoms from 1994 to 2002 are consistent with general patterns observable at other sites along the Lower Missouri River: bare ground is first occupied by weeds/forbs/grasses, and subsequently, depending on site-specific circumstances, by cottonwoods/willows and mature trees. Certainly, human activities affect the patterns of vegetative land-cover distribution or succession, such as the construction associated with the relocation of a levee by the USACE on Overton Bottoms. Bare ground replaced agricultural fields during construction, which was subsequently replaced by weeds/forbs/grasses after the construction was completed.

Table 4. Total perimeter length for each land-cover class per year.

[values are in meters]

\begin{tabular}{lrrrrr}
\hline \multicolumn{1}{c}{ Land-cover Class } & \multicolumn{1}{c}{$\mathbf{1 9 9 4}$} & \multicolumn{1}{c}{$\mathbf{1 9 9 6}$} & \multicolumn{1}{c}{$\mathbf{1 9 9 8}$} & \multicolumn{1}{c}{$\mathbf{2 0 0 0}$} & \multicolumn{1}{c}{$\mathbf{2 0 0 2}$} \\
\hline Water & 50,400 & 50,400 & 50,400 & 50,700 & 53,820 \\
Bare ground & 27,360 & 19,860 & 21,060 & 26,700 & 35,280 \\
Weeds/forbs/grasses & 107,100 & 115,140 & 115,920 & 115,500 & 136,740 \\
Cottonwoods/willows & 28,320 & 57,540 & 86,220 & 103,620 & 119,820 \\
Mature trees & 62,220 & 62,220 & 62,220 & 61,860 & 60,780 \\
Agricultural fields & 28,380 & 27,900 & 27,840 & 29,700 & 31,740 \\
Roads & 31,200 & 31,200 & 31,200 & 37,620 & 37,620 \\
Total & 334,980 & 364,260 & 394,860 & 425,700 & 475,800 \\
\hline
\end{tabular}


Similarly, natural processes and associated landforms seem to affect the distribution or succession of vegetative landcover classes. Flood-plain depressions associated with channel meandering, abandonment, and filling are likely to support a much different assemblage of plants than natural levees or sand splays associated with channel avulsions (for example, Heimann and Mettler-Cherry, 2004; Hupp and Osterkamp, 1996; Scott and others, 1996). The distribution of cottonwoods/willows on Overton Bottoms between 1994 and 2002 suggests a relation between the distribution or succession of vegetative land-cover classes and Lower Missouri River landforms. While the total area of cottonwoods/willows increased from 72 ha in 1994 to 702 ha in 2002, the increase was not uniform across Overton Bottoms, but limited to specific areas on the flood plain. Most notable are those areas that are adjacent to the river, unprotected by levees, and undisturbed by human activities.

A more specific example of the interdependence of the distribution of cottonwoods/willows and landform can be seen on the western side of Overton Bottoms. Along the valley wall northwest of I-70 there are a series of curvilinear polygons of cottonwoods/willows (figs. 7 and 8). Their location correlates well with channel fill allounits mapped by Holbrook and others (this volume, chapter 2, fig. 3). The resolution of the satellite imagery is coarser than the typical width of these features. However, the shape of the polygons mimics the shape of several secondary channels mapped by Holbrook suggesting a land-cover/landform relation between cottonwoods/willows and filled channels.

This relation likely is dependent on the structure and composition of the channel fill features. Channel-fill allounits tend to occupy low areas on the flood plain, and are U-shaped in cross section and filled with fined-grained low permeability strata with internal bedding that is concave up. This structure slows the infiltration of surface water sufficiently to cause water to collect at the surface. The cottonwoods/willows landcover class has expanded along these features since 1994. This preferential pattern of occupation can be seen by comparing the distribution pattern of cottonwoods/willows from 1994 through 2002 to the surfical alluvium map of the area (this volume, chapter 2, fig. 2).

Vegetation community distributions and locations of change also relate broadly to land-surface altitude, presumably through controls on ground-water availability. In the Overton Bottoms North Unit, low-lying land surfaces adjacent to the channel on the north and northwest consistently show shallower depths to ground water compared to areas closer to I-70 (Kelly, this volume, chapter 3, figs. 10-12). As shown in the land-cover maps, the lower areas have preferentially grown up in the cottonwoods/willows community while the higher areas with deeper ground water are dominated by the weeds/forbs/ grasses class (figs. 2, 3, 5, 7, 9, 11).

The only locations with relatively deep ground-water table and cottonwoods/willows growth are curvilinaer channelfill areas (fig. 9) where depth to ground water is presumably less and water retention is probably greater than surrounding areas. Adjacent areas mapped as point-bar allounits have persisted in weeds/forbs/grasses presumably because pointbar allounits are not as effective in retaining water near the surface. Point-bar allounits typically include inter-bedded and inclined permeable sand and mud that direct water down and away from the surface. Weeds/forbs/grasses appear to be more tolerant of this situation than cottonwood or willow seedlings. In each of his scenarios, Kelly's figures 10-15 (this volume, chapter 3) show lower estimated depths to ground water adjacent to I-70 where it crosses Overton Bottoms.

With time, cottonwoods/willows likely will occupy more of Overton Bottoms if trends of the last 10 years continue (fig. 12). During 1994-2002 cottonwoods/willows expanded at the expense of weeds/forbs/grasses so now each class covers approximately one-third of the Overton Bottoms area (fig. $12 A)$.

Mature forest community, agricultural land, bare ground/ sand, and water classes occupy the last one-third of area within the conservation areas. Rates of change of total area of cottonwoods/willows and weeds/grasses/forbs have slowed since 1998. As the area of cottonwoods/willows has increased at the expense of the weeds/forbs/grasses class, the total edge of these two classes has increased (fig. 12B). This trend is indicative of complex intergrowth of patches, in part resulting from preferential growth of cottonwoods/willows along arcuate channel fills. The trend in total core area (area within a 30-m edge buffer around each patch) is similar to percent area in each class (fig. 12C). Mean core area per patch has been decreasing markedly for weeds/forbs/grasses and increasing modestly for cottonwoods/willows (fig. 12D).

These changes in patch characteristics may have implications for habitat quality and quantity for wildlife at Overton Bottoms. Growth of flood-plain forest has been associated with increase of smaller, more scattered patches on the Wisconsin River flood plain (Freeman and others, 2003). These authors noted that increased core patch size is often associated with increased species richness of forest birds (for example, Robbins and others, 1989; Freemark and Merriam, 1986, Yahner and Scott, 1988). However, similar to Overton Bottoms, the Wisconsin River example indicated that forest patches were growing in convolute shapes with abundant edge. While edge has often been considered to increase wildlife habitat value (Leopold, 1933; Logan and others, 1985), forest edges also have been associated with increased predation of some bird species (Paton, 1994). Hence, changes in patch size and shape at Overton Bottoms will probably continue to have substantial effects on habitat quality and availability, but assessment is required on a species by species basis. The underlying template of surficial geology and topography will likely continue to influence a complex spatial pattern of landcover patches. 


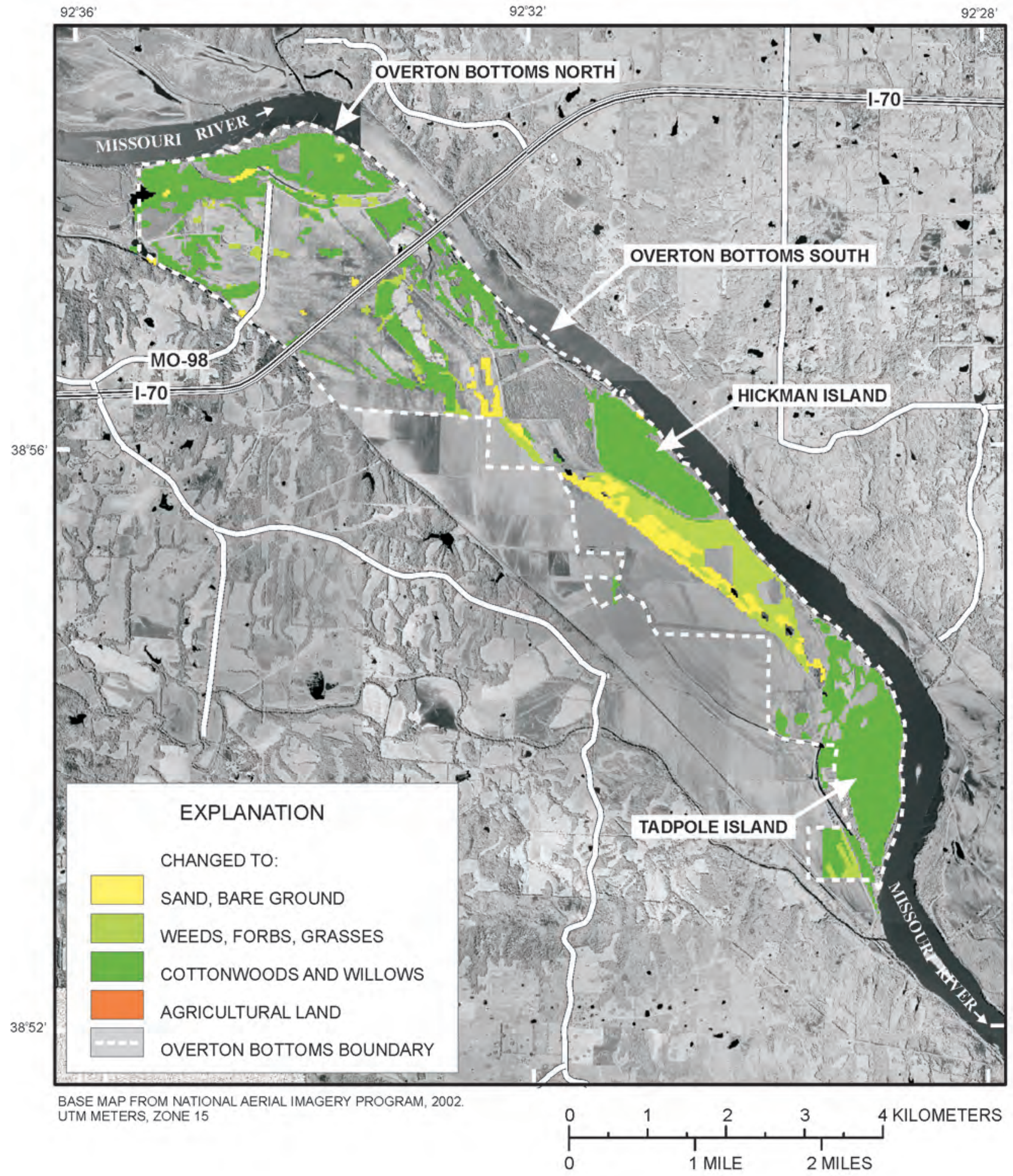

Figure 11. Overton Bottoms showing the change in vegetation and land-cover classes that occurred between September 19, 1994 and September 4, 2002. Areas where the vegetation and land-cover classes did not change are uncolored. Areas where they did change are shown in the color of the vegetation and land-cover class that they became. 


\section{Conclusions}

This investigation demonstrated that Landsat TM satellite image data can be used to map and monitor the spatial and temporal distribution of general land-cover classes along the Lower Missouri River. General patterns observed between 1994 and 2002 are consistent with vegetation succession at other sites along the Lower Missouri River, and there appears to be a strong relation between physical processes and the distribution of vegetative-land cover on the flood plain.

This study has also documented a relation between the distribution of flood-plain land cover and flood-plain land form. This is important to natural resource managers who are interested in rehabilitating or re-establishing specific floodplain habitats along the Lower Missouri River. This project has shown that land-cover distribution patterns are affected by underlying allostratigraphic structures.
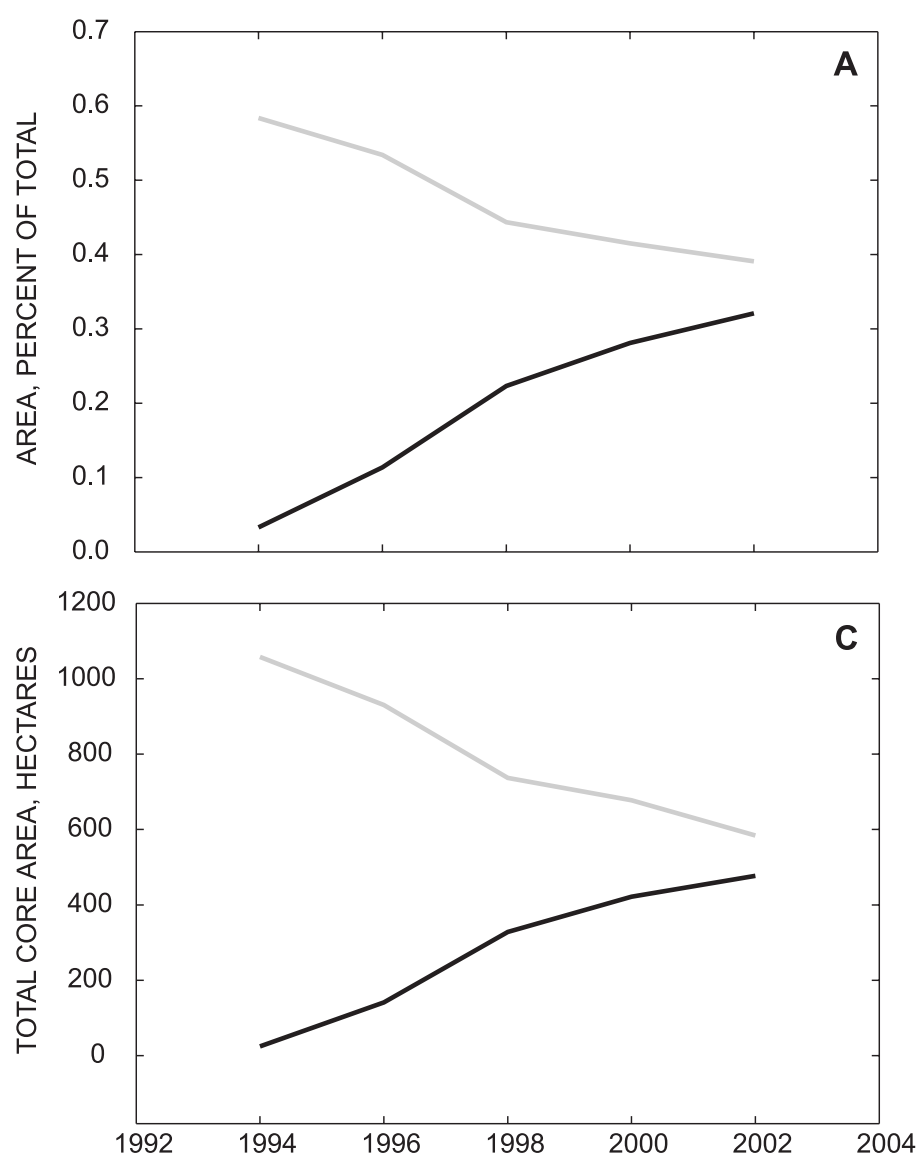

EXPLANATION
Knowing one can help predict the occurrence of the other. Approximately 25 years of TM data is available to map the spatial and temporal distribution of vegetation and general land use of the Lower Missouri River Valley. At sites like Overton Bottoms, land-cover changes can be mapped and analyzed, and used to monitor land-use management strategies and practices, or combined with geologic and hydrologic data to identify sites that are suitable for habitat restoration or rehabilitation.

Additional studies, using higher resolution image data should be conducted to refine our understanding of the relationships between landform, landform processes, and land cover. Our understanding can be further refined by incorporating high-resolution terrain data to look at site-specific surface features, such as the surface expression of filled channels, or small meander-scroll depressions. It would also be useful to continue monitoring Overton Bottoms to determine if landcover trends conform to habitat management objectives. The
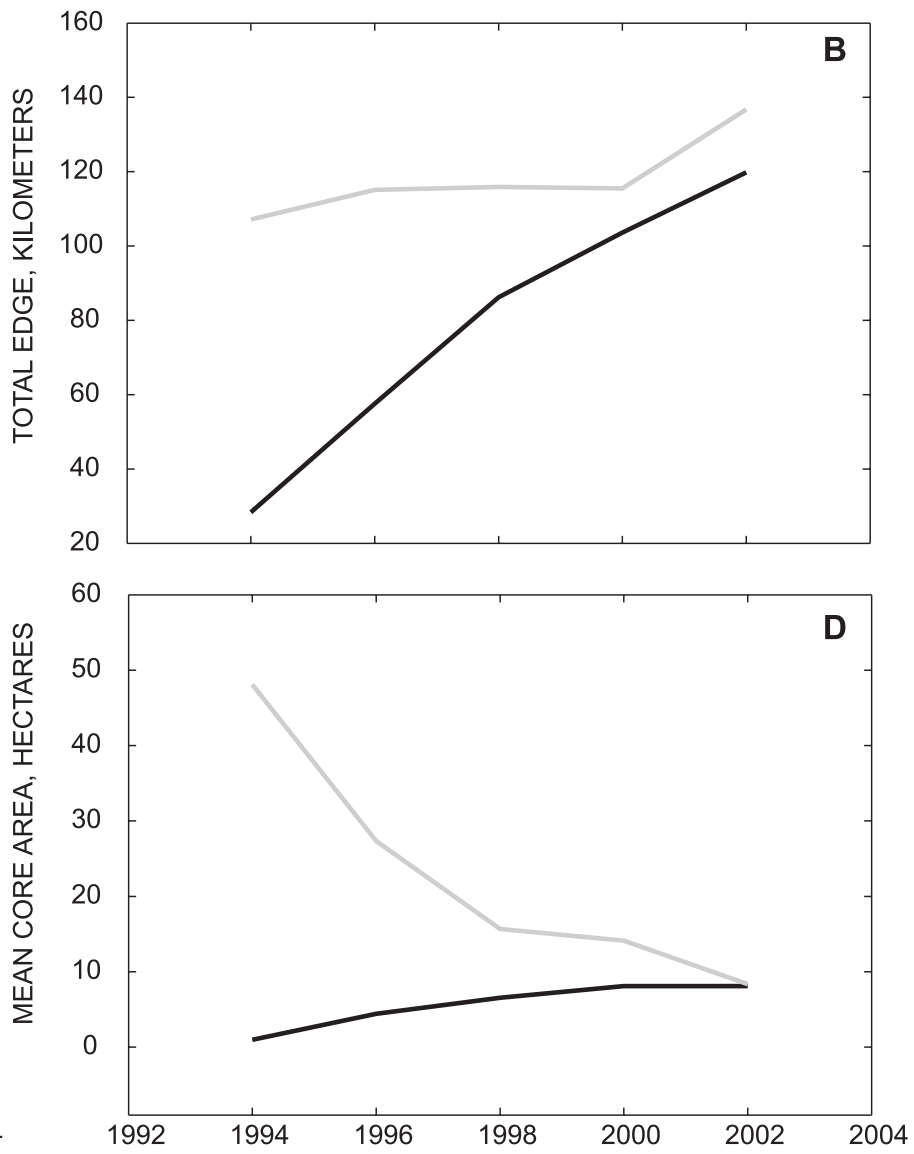

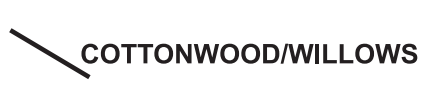

WEEDS/FORBS/GRASSES

Figure 12. Patch characteristics of Overton Bottoms land-cover classes. A. Changes in area of cottonwoods/willows and weeds/forbs/grasses classes through time as percent of total area in conservation areas. B. Changes in edges of cottonwoods/ willows and weeds/forbs/grasses classes through time as total edge length. C. Changes in core area in cottonwoods/willows and weeds/forbs/grasses classes through time as total core area. D. Changes in core area in cottonwoods/willows and weeds/forbs/ grasses classes through time as mean core area per patch. 
increase in the total edge of the weeds/forbs/grasses and cottonwoods/willows suggest increasing complexity of the edges of these land-cover classes. Additional monitoring is required to document trends in these relations and assess effects on wildlife.

\section{References Cited}

Chapman, D.C., Ehrhardt, E. A., Fairchild, J.F., Jacobson, R.B., Kelly, B.P., Mabee. W.R., Poulton, P.C., Sappington, L.C., 2004, Ecological dynamics of wetlands at Lisbon Bottoms, Big Muddy National Fish and Wildlife Refuge, Missouri: U.S. Geological Survey Open-File Report 2004-1036, 160 p.

Chen, J., and Franklin, J.F., 1990, Microclimatic pattern and basic biological responses at the clearcut edges of old-growth Douglas-fir stands: Northwest Environmental Journal, v. 6, p. 424-425.

Freeman, R.E., Stanley, E.H., and Turner, M.G., 2003, Analysis and conservation implication of landscape change in the Wisconsin River floodplain, USA: Ecological Applications, v. 13 , p. 416-431.

Freemark, K.E., and Merriam, H.G., 1986, Importance of area and habitat heterogeneity to bird assemblages in temperate forest fragments: Biological Conservation, v. 36, p. $115-141$.

Funk, J.L., and Robinson, J.W., 1974, Changes in the channel of the Lower Missouri River and effects on fish and wildlife: Missouri Department of Conservation Aquatic Service, $112 \mathrm{p}$.

Galat, D.L., Robinson, J.W., and Hesse, L.W., 1996, Restoring aquatic resources to the Lower Missouri River-issues and initiatives, in Galat, D.L., and Frazier, A.G., eds., Overview of river-flood plain ecology in the upper Mississippi River Basin, v. 3 of Kelmelis, J.A., ed., Science for flood plain management into the 21 st century: Washington, D.C., U.S. Government Printing Office, p. 49-71.

Heimann, D.C., and Mettler-Cherry, P.A., 2004, Hydrologic, soil, and vegetation gradients in remnant and constructed riparian wetlands in West-Central Missouri, 2001-2004: U.S. Geological Survey Scientific Investigations Report 2004-5216, 160 p.

Hupp, C.R., and Osterkamp, W.R., 1996, Riparian vegetation and fluvial geomorphic processes: Geomorphology, v. 14, p. 277-295.

Jacobson, R.B., Johnson, H.E., Laustrup, M.S., D’Urso, G.J., and Reuter, J.M., 2004, Physical habitat dynamics in four side-channel chutes, Lower Missouri River: U.S. Geological Survey Open-File Report 2004-1071, 60 p.
Kalliola, R., and Puhakka, M., 1998, River dynamics and vegetation mosaicism-case study of the river Kamajohka, northernmost Finland: Journal of Biogeography, v. 15, p. 703-719.

Leopold, A., 1933, Game management: New York, Charles Scribners, $481 \mathrm{p}$.

Logan, W., Brown, E.R., Longrie, D., Herb, G. [and others], 1985, Edges, in Brown, E.R., ed., Management of wildlife and fish habitats in forests of western Oregon and Washington, R6-F\&WL-192-1985: Portland, Oreg., U.S. Department of Agriculture, Forest Service, Pacific Northwest Region, p. 115-127.

Loveland, T.R., Sohl, T.L., Stehman, S.V., Gallant, A.L., Sayler, K.L., and Napton, D.E., 2002, A strategy for estimating the rates of recent United States land-cover changes: Photogrammetric Engineering and Remote Sensing, v. 68, p. 1091-1099.

McGarigal, K., and Marks, B.J., 1995, FRAGSTATS-spatial pattern analysis program for quantifying landscape structure, Gen. Tech. Rep. PNW-GTR-351: Portland, Oreg., U.S. Department of Agriculture, Forest Service, Pacific Northwest Research Station, 122 p.

National Research Council, 2002, The Missouri River ecosystem-exploring the prospects for recovery: Washington, D.C., National Academies Press, 141 p.

Paton, P.W.C., 1994, The effect of edge on avian nest success-how strong is the evidence?: Conservation Biology, v. 8, p. 17-26.

Robbins, C.S., Dawson, D.K., and Dowell, B.A., 1989, Habitat area requirements of breeding forest birds of the middle Atlantic states: Wildlife Monographs, v. 103, 34 p.

Robertson, K.M., and Augspurger, C.K., 1999, Geomorphic processes and spatial patterns of primary forest succession on the Bogue Chitto River, USA: Journal of Ecology, v. 87, p. 1052-1063.

Scott, M.L., Friedman, J.M., and Auble, G.T., 1996, Fluvial process and the establishment of bottomland trees: Geomorphology, v. 14, p. 327-339.

U.S. Geological Survey, 2005, USGS-NPS national vegetation mapping program-program documents and standards: U.S. Geological Survey, Reston, Va., accessed November, 2005, at URL http://biology.usgs.gov/npsveg/standards.html.

Yahner, R.H., and Scott, D.P., 1988, Effects of forest fragmentation on depredation of artificial nests: Journal of Wildlife Management, v. 52, p. 158-161. 


\section{Cottonwood (Populus deltoides) Growth Response to Hydrologic Alteration, Overton Bottoms North, Missouri River Flood Plain}

By Thomas M. Faust, Robert B. Jacobson, and Stephen G. Pallardy

Chapter 5 of

Science to Support Adaptive Habitat Management: Overton Bottoms North Unit, Big Muddy National Fish and Wildlife Refuge, Missouri

In cooperation with the U.S. Fish and Wildlife Service

Scientific Investigations Report 2006-5086

U.S. Department of the Interior

U.S. Geological Survey 


\section{Contents}

Abstract
Introduction.
$\quad$ Background
Purpose and Scope
Methods
Results and Discussion
References Cited

\section{Figures}

1. Map showing Overton Bottoms North Unit, Big Muddy Fish and Wildlife Refuge .........95

2. Photographs showing growth-rate measurements .......................................................96

3-10. Graphs showing-

3. Average cottonwood growth rates and environmental variables ............................98

4. Growth rates of cottonwood by week for all plots ................................................99

5-7. Topographic cross sections showing-

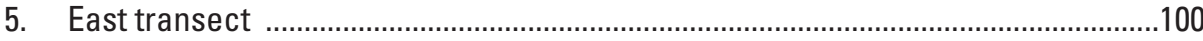

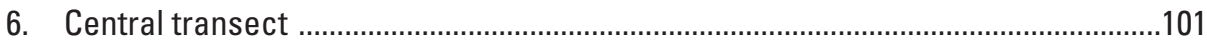

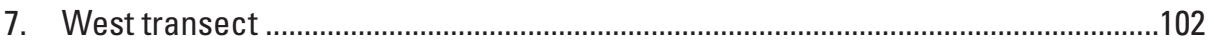

8-10. Graphs showing-

8. Basal area incremental growth rates ....................................................................103

9. Relation between growth rate and density of individual trees in plots ..................104

10. Missouri River discharge during 2004 compared to historical flow durations ......104

\section{Tables}

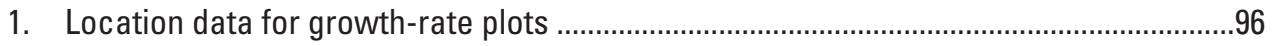

2. Summary basal area and density data for growth-rate plots ...........................................97 


\title{
Chapter 5 \\ Cottonwood (Populus deltoides) Growth Response to Hydrologic Alteration, Overton Bottoms North, Missouri River Flood Plain
}

\author{
by Thomas M. Faust ${ }^{1}$, Robert B. Jacobson², Stephen G. Pallardy'
}

\begin{abstract}
Cottonwood (Populus spp.) regeneration in arid and semiarid regions of North America is a major concern because of documented population declines in the species. Declines have been associated with changes in flow regulation, or the lowering of ground-water altitudes due to flow regulation, or changes in channel morphology. This study assesses the potential impact of a constructed side-channel chute on cottonwood growth on the Missouri River flood plain in central Missouri. Dendrobands were placed on 75 trees across three transects and growth was measured each week June-September, 2004. Changes in growth rate were related to environmental attributes at each site. We hypothesized that an excavated side-channel chute would lower ground-water levels causing water stress in the cottonwood communities. Alternatively, we also hypothesized that the side-channel chute could provide enhanced ground-water recharge during periods of high river discharge. We found that increases in basal area were greater at sites closer to either the channel or the Missouri River, suggesting that the side-channel chute is affecting cottonwood growth by recharging ground-water levels during periods of high discharge. Temporal variations in growth rates were not apparent due to air temperature, solar radiation, or rainfall, and spatial variations did not relate to stand density.
\end{abstract}

\section{Introduction}

Declines in cottonwood communities throughout arid and semi-arid areas of the United States have prompted extensive research on the conditions necessary for regeneration and survival (Johnson, 2002; Shafroth and others, 2002). As obligate riparian species, cottonwood regeneration and survival have been linked to fluvial processes of erosion, deposition, flooding, and drought stress. Changes in these processes by reha-

\footnotetext{
${ }^{1}$ Forestry Department, University of Missouri, Columbia, Missouri

${ }^{2}$ U.S. Geological Survery, Columbia, Missouri
}

bilitation actions may serve to enhance or diminish conditions conducive to survival. The constructed side-channel chute at the Overton Bottoms North Unit, Big Muddy National Fish and Wildlife Refuge, presented an opportunity to address the linkage between altered hydrology and effects on cottonwood growth in a relatively controlled field setting. In particular, we addressed the question of whether the chutes' evident effect on ground-water altitudes serves to enhance or diminish cottonwood growth.

\section{Background}

Riparian vegetation communities are thought to be structured by fluvial dynamics-flooding, erosion, and sediment deposition-which affect all aspects of riparian species' life-histories (Brinson, 1990; Mitsch and Gosselink, 2000; Decamps, 1997). Fluvial dynamics determine the type and size of regeneration sites, influence seedling and adult mortality, control water relations of the vegetation community, and influence availability of nutrients. In addition to dynamics associated with floods, riparian vegetation communities can also be stressed by lack of adequate moisture. This can occur during periods of natural drought (Reily and Johnson, 1982), because of anthropogenic changes in stream discharge (Rood and Mahoney, 1990; Segelquist and others, 1993), and due to changes in channel morphology (Scott and others, 2000).

Water stress has important implications for plant communities because it is probably the most limiting factor in plant growth (Kramer and Boyer, 1995). In riparian systems, water stress can be the result of both low- and high-water conditions; in this paper we are concerned primarily with water stress induced by low-water conditions. Low-water conditions induce water stress in plants when ground-water depths fall below a plant's rooting zone. This results in low levels of soil water potential. As soil moisture declines, water molecules adhere to themselves and soil particles, thereby hindering the continued flow of water into plants (Kozlowski and Pallardy, 1997). 
Plant water stress potentially leads to several different responses. Most woody plants have an evolutionary strategy of desiccation avoidance with the most prevalent response in woody plants being the closure of stomata on leaves. This increases leaf water potential resulting in the decline of water movement through the plant. The reduction in transpiration comes at a physiological cost to the plant because carbon dioxide $\left(\mathrm{CO}_{2}\right)$ also must enter the leaves through the stomata. The decrease of $\mathrm{CO}_{2}$ entering the plant results in the reduction of photosynthesis, which has important implications for plant survival, growth, and competition. Plants have been found to respond to changes in water status through changes in carbon allocation; species in regions with high drought stress have high ratios of root carbon to stem carbon (Keyes and Grier, 1981).

The family Salicaceae, of which the genus Populus is a member, is thought to have evolved in response to the annual spring rise found on large rivers throughout the northern hemisphere (Karrenberg and others, 2002). Eastern cottonwood (Populus deltoides) is found throughout the midwest and southeastern U.S. along all major rivers and their tributaries. They survive on deep infertile soils with ground-water altitudes typically $0.6-1.8 \mathrm{~m}$ (meters) below the surface and rarely occur as well-formed trees at altitudes more than 5-7 m higher than average stream stage. Cottonwood seedling dispersal starts in May in the South and June in the North, continuing through mid-July in both regions (Burns and Honkala, 1990). Cottonwoods are prolific seeders with over 48 million seeds estimated on one tree. Cottonwood seeds are light and can disperse seeds over $30 \mathrm{~m}$ through the air (Johnson, 1965), or over much greater distances by water. Cottonwood germination is thought to be dependent on flooding to provide a baremineral soil substrate for the very shade-intolerant cottonwood seedlings (Karrenberg and others, 2002). The combination of seed-release coordinated with spring floods, large quantities of seedlings, high dispersal rates, and high shade intolerance is thought to be an evolutionary response to the depositional features created by the annual spring floods in most northern hemisphere rivers (Karrenberg and others, 2000).

Carbon allocation in cottonwoods is thought to be concentrated in roots (Woolfolk and Friend, 2003), at least in the early stages of life. Cottonwood seedling roots must grow to maintain contact with the ground water as the flood waters recede. Roots of first-year seedlings may grow as much as 1 $\mathrm{m}$ by the end of the growing season (Segelquist and others, 1993). As the seedlings develop, carbon allocation may be shifted to the stem (Coleman and others, 2004); as a shade intolerant species, competition for light requires rapid height growth. After the seedling stage, tree stem growth is a good measure of water stress because the stem receives the last investments of carbon allocation (Bloom and others, 1985).

Riparian cottonwood (Populus ssp.) communities throughout the arid and semi-arid west have undergone major shifts in species composition and areal extent, attributed to changes in hydrology (Rood and Mahoney, 1990; Johnson, 1994; Scott and others, 1997, Johnson, 2002; Shafroth and others, 2002). Cottonwood survival appears to be limited by different mechanisms among the studied river systems (Segelquist and others, 1993). In northern climates, cottonwood regeneration may be constrained by whether seeds are deposited high enough above the channel to avoid winter ice-scouring (Johnson, 1994; Scott and others, 1997; Auble and Scott, 1998). In other areas, cottonwood seedling survival is thought to be more strongly limited by decreased ground-water levels causing cavitation of the xylem (Rood and Mahoney 1990; Tyree and others, 1994). These authors provide evidence that the gradual decline of stream discharge after flooding allows the growing root system to maintain contact with the ground water and avoid cavitation. Water management projects, such as diversion for irrigation, can result in rapid decreases in flow and ground-water altitudes, causing drought mortality both in seedlings and adults (Tyree and others, 1994). Drought mortality can also have climatic causes. For example, Albertson and Weaver (1945) documented the effects of the 1930's drought on riparian communities; they found over 80 percent mortality of cottonwoods along a small stream in Kansas.

\section{Purpose and Scope}

The engineered side-channel chute at the Overton Bottoms North Unit, Big Muddy National Fish and Wildlife Refuge (fig. 1), presents a field-based opportunity to investigate the connections between ground-water and cottonwood growth. Ground-water dynamics are dependent on many factors such as the source of water, soil texture and stratification, and site geomorphology. In the case of the side-channel chute at Overton Bottoms North, geomorphology has been dramatically changed by excavation of the side-channel chute (Jacobson, this volume, chapter 1). We hypothesize that construction of the side-channel chute may have affected groundwater/cottonwood community connections in two ways: (a) lowering of ground-water levels due to enhanced drainage to the chute may lead to increased moisture stress in the communities adjacent to the chute (the "edge effect"), or (b) with high discharges, the chute may provide enhanced recharge of ground water with consequent increases of growth adjacent to the chute.

This field-based investigation explores these hypotheses within the Missouri River valley-bottom landscape. The intent is to increase understanding of the relative effects of geomorphology, ground-water flow, surface-water flow, surficial geology, climatic events and intra-community competition on cottonwood growth. While this study is not intended to define relations with statistical rigor, we hope that the understanding developed will provide guidance for adaptive management decisions and motivation for more rigorous testing of these ideas. 


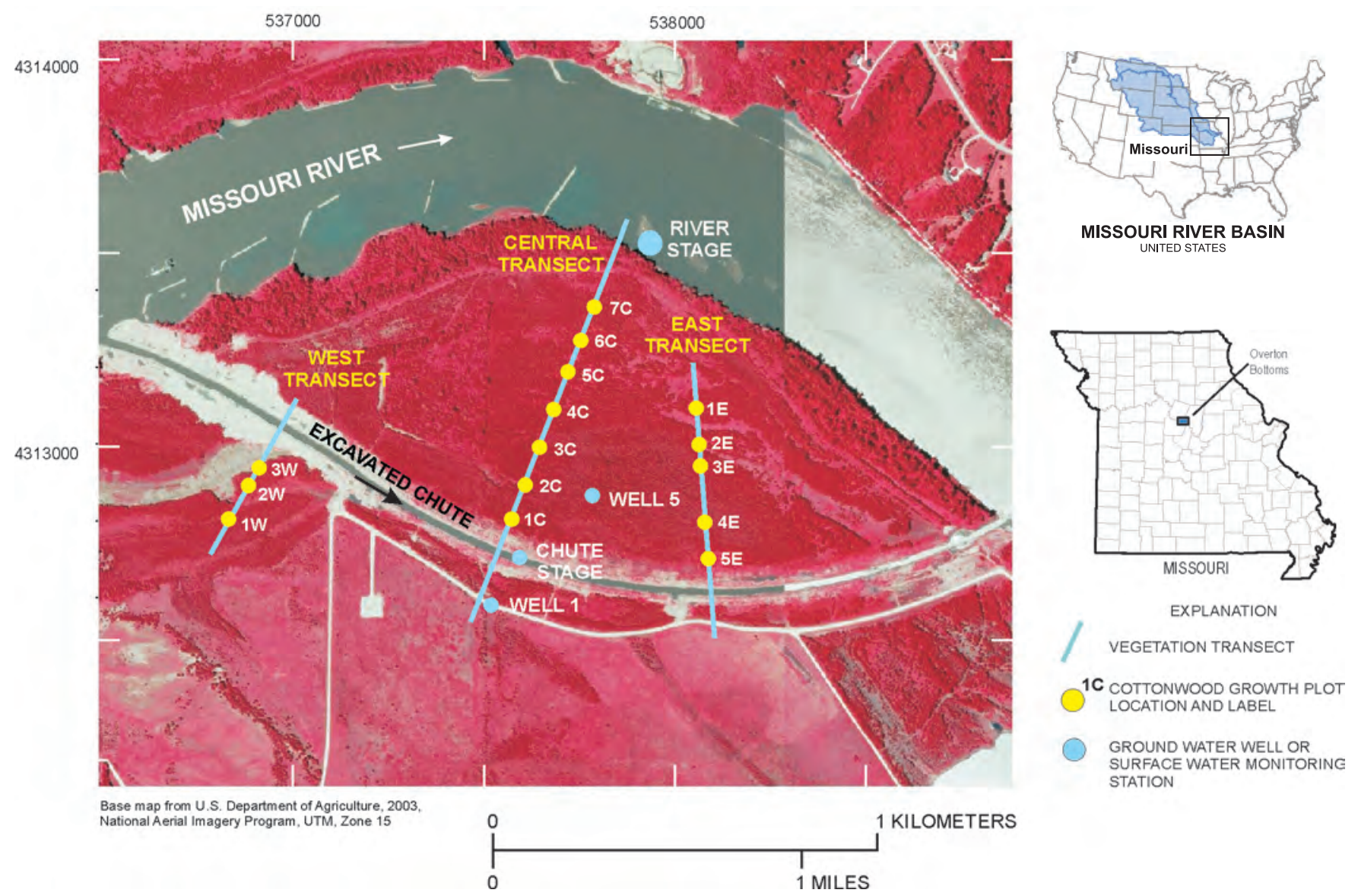

Figure 1. Location of the Overton Bottoms North Unit, Big Muddy National Fish and Wildlife Refuge, showing cottonwood growth-rate sampling transects, plot locations, and ground-water well and river-stage measurement locations.

\section{Methods}

Cottonwood growth was evaluated during summer 2004 on transects aligned perpendicular to the Overton Bottoms North side-channel chute (fig. 1). Data collection was coordinated with hydrologic and surficial geologic assessments in order to provide the most context to explain cottonwood growth rates.

Sampling plots were laid out along three transects (fig. 1, table 1). These transects are labeled as west, central, and east; the east and central transects are on the island created by the chute, while the west transect is on the mainland. Plot locations were mapped in the field with a handheld global positioning system (GPS) unit with typical accuracy of $\pm 5 \mathrm{~m}$. Plots were evaluated for inclusion in the study based on the following criteria: (1) the majority of the canopy had to be eastern cottonwood, (2) there were at least five cottonwoods with different diameters at breast height (dbh) ranging from 9-30 $\mathrm{cm}$ (centimeters) within a $10 \mathrm{~m}^{2}$ (square meters) area, and (3) plots were located along the pre-determined transect. Fifteen plots were selected with nominal spacing at $100 \mathrm{~m}$ intervals (fig. 1, table 1); however, intervals were varied to ensure that plots were centered in cottonwood patches. For example, on the east transect spacing varied from 50 to $150 \mathrm{~m}$ to avoid patches of black willow (Salix nigra) trees.

Dendrobands were used to measure variation in cottonwood growth during the study. Dendrobands are simply thin stainless-steel bands that can be wrapped around a tree stem to measure variation in circumference over time (Cattelino and others, 1986; fig. 2). A spring keeps the dendroband under tension, and a caliper is used to measure changes in tree girth (circumference). Dendrobands were placed on five cottonwood stems per plot. Trees were selected based on three criteria: (1) the crown had to be in the canopy, (2) the trees had no signs of physical or insect damage, and (3) trees had a range of diameters. In addition, initial and final dbh were recorded on all trees selected for dendrobands.

Dendrobands were measured each week from June 21, 2004 to September 21, 2004, with a final measurement on October 5, 2004. The measurements were taken in an established plot order between 7:00 a.m. and 1:00 p.m., with the exception of the first week when bands were being applied 
Table 1. Location data for growth-rate plots.

[UTM, Universal Transverse Mercator; NAVD 88, North American Vertical Datum; m, meters; cm, centimenter]

\begin{tabular}{|c|c|c|c|c|c|c|c|}
\hline Transect & Plot Label & $\begin{array}{c}\text { East } \\
\text { UTM } \\
\text { (m) }\end{array}$ & $\begin{array}{l}\text { North } \\
\text { UTM } \\
\text { (m) }\end{array}$ & $\begin{array}{c}\text { Surface } \\
\text { altitude, } \\
\text { NAVD 88, } \\
\text { (m) }\end{array}$ & $\begin{array}{c}\text { Distance } \\
\text { to chute } \\
\text { (m) }\end{array}$ & $\begin{array}{c}\text { Distance } \\
\text { to river } \\
\text { (m) }\end{array}$ & $\begin{array}{c}\text { Shorter } \\
\text { distance } \\
\text { to water } \\
\text { (m) }\end{array}$ \\
\hline \multirow[t]{3}{*}{ West } & $1 \mathrm{~W}$ & 536846 & 4312804 & 176.9 & 265 & 551 & 265 \\
\hline & $2 \mathrm{~W}$ & 536894 & 4312892 & 176.6 & 165 & 468 & 165 \\
\hline & $3 \mathrm{~W}$ & 536919 & 4312936 & 176.3 & 115 & 450 & 115 \\
\hline \multirow{5}{*}{ Central } & $2 \mathrm{C}$ & 537615 & 4312892 & 176.8 & 175 & 665 & 175 \\
\hline & $3 C$ & 537651 & 4312985 & 177.0 & 275 & 565 & 275 \\
\hline & $4 \mathrm{C}$ & 537686 & 4313079 & 177.0 & 375 & 465 & 375 \\
\hline & $5 \mathrm{C}$ & 537722 & 4313172 & 176.9 & 475 & 365 & 365 \\
\hline & $6 \mathrm{C}$ & 537758 & 4313265 & 177.0 & 575 & 265 & 265 \\
\hline \multirow{3}{*}{ East } & $3 \mathrm{E}$ & 538075 & 4312946 & 176.1 & 315 & 415 & 315 \\
\hline & $4 \mathrm{E}$ & 538086 & 4312796 & 176.7 & 160 & 505 & 160 \\
\hline & $5 \mathrm{E}$ & 538094 & 4312697 & 175.8 & 60 & 610 & 60 \\
\hline
\end{tabular}
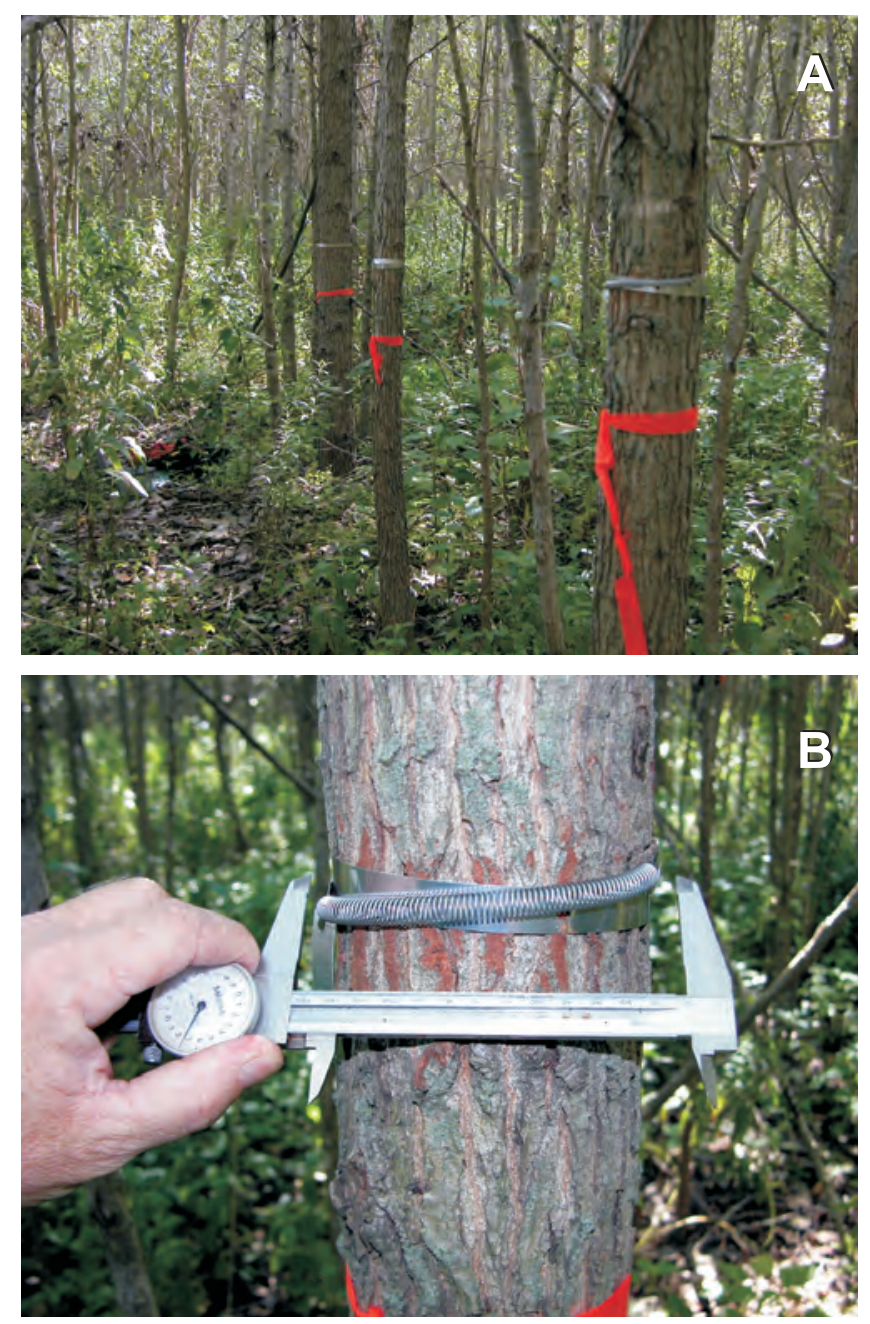

(8:00 a.m.-6:00 p.m.) and August 24 when access to the site was not available until the afternoon (12:00-6:00 p.m.).

Increases in circumference were measured and converted to basal area and basal area increments (BAI) were used to estimate the percentage of growth in the sampled cottonwoods. To estimate the weekly BAI, the starting dbh was converted to a tree circumference and the weekly increase or decrease in the dendroband was added to this circumference. The circumference was then converted into the basal area for the tree that week and the previous week's basal area was subtracted from it.

Because basal area growth can also vary with competition among trees for light, water, or other resources, we also assessed total basal area and number of trees/ha (hectare) for each plot with dendrobands. The variable area plot method was used with the plot center chosen to incorporate all trees with dendrobands. Plot-scale basal area was estimated with a 10X meter prism and number of trees/ha was recorded in a 5 - $\mathrm{m}$ radius plot $\left(78.54 \mathrm{~m}^{2}\right)$. Both basal area and trees/ha were recorded by species (table 2 ).

For comparison with tree-growth rates, we also collected information on geomorphology, surficial geology, groundwater and surface-water hydrology, and climate. Surficial geologic and ground-water information was compiled from data presented in Holbrook and others (this volume, chapter 2) and Kelly (this volume, chapter 3). Surface-water hydrologic

Figure 2. Growth-rate measurements. A. Typical plot showing density of cottonwood and trees selected for measurement. B. Dendroband and measurement with calipers. 
Table 2. Summary basal area and density data for growth-rate plots.

[m, meters; ha, hectare]

\begin{tabular}{|c|c|c|c|c|c|c|c|c|c|}
\hline \multirow[b]{2}{*}{ Transect } & \multirow[b]{2}{*}{$\begin{array}{c}\text { Plot } \\
\text { Label }\end{array}$} & \multicolumn{4}{|c|}{ Basal area (m²/ha) } & \multicolumn{4}{|c|}{ Number/ha } \\
\hline & & $\begin{array}{c}\text { Cottonwood } \\
\text { Populus } \\
\text { deltoides }\end{array}$ & $\begin{array}{c}\text { Boxelder } \\
\text { Acer } \\
\text { negundo }\end{array}$ & $\begin{array}{c}\text { Black } \\
\text { Willow } \\
\text { Salix } \\
\text { nigra }\end{array}$ & Total & $\begin{array}{c}\text { Cottonwood } \\
\text { Populus } \\
\text { deltoides }\end{array}$ & $\begin{array}{c}\text { Boxelder } \\
\text { Acer } \\
\text { negundo }\end{array}$ & $\begin{array}{c}\text { Black } \\
\text { Willow } \\
\text { Salix } \\
\text { nigra }\end{array}$ & Total \\
\hline \multirow[t]{3}{*}{ West } & $1 \mathrm{~W}$ & 90 & & & 90 & 4,000 & & 400 & 4,400 \\
\hline & $2 \mathrm{~W}$ & 70 & & 10 & 80 & 2,700 & & 4,700 & 7,400 \\
\hline & $3 \mathrm{~W}$ & 80 & & 10 & 90 & 4,600 & & 2,800 & 7,400 \\
\hline \multirow[t]{7}{*}{ Central } & $1 \mathrm{C}$ & 130 & & & 130 & 2,200 & & & 2,200 \\
\hline & $2 \mathrm{C}$ & 80 & & & 80 & 3,200 & & & 3,200 \\
\hline & $3 \mathrm{C}$ & 70 & & & 70 & 1,100 & 100 & & 1,200 \\
\hline & $4 \mathrm{C}$ & 120 & 10 & & 130 & 1,100 & 600 & & 1,700 \\
\hline & $5 \mathrm{C}$ & 100 & 20 & & 120 & 1,000 & 800 & & 1,800 \\
\hline & $6 \mathrm{C}$ & 70 & 10 & & 80 & 800 & 600 & & 1,400 \\
\hline & 7C & 110 & & & 110 & 2,000 & 400 & & 2,400 \\
\hline \multirow[t]{5}{*}{ East } & $1 \mathrm{E}$ & 160 & & & 160 & 4,700 & & & 4,700 \\
\hline & $2 \mathrm{E}$ & 100 & & & 100 & 4,200 & & 1,100 & 5,300 \\
\hline & $3 \mathrm{E}$ & 110 & & & 110 & 3,600 & & & 3,600 \\
\hline & $4 \mathrm{E}$ & 100 & & & 100 & 1,300 & & & 1,300 \\
\hline & $5 \mathrm{E}$ & 120 & & & 120 & 3,200 & & & 3,200 \\
\hline
\end{tabular}

data were compiled from Boonville, Missouri streamflow gage (USGS stream-gaging station number 06909000), 8-river km (kilometers) upstream; surface-water altitudes were extrapolated to the study site based on regression models. Climatic data were compiled from the University of Missouri meteorological station at Sanborn Field, Columbia, Missouri, $20 \mathrm{~km}$ west of Overton Bottoms. The Sanborn Field site has a long, high-quality climatic record, but it is not a bottomland site; thus temperatures and solar radiation at Overton Bottoms may vary slightly from the values obtained from Sanborn Field.

\section{Results and Discussion}

The results of the study support the general hypothesis that ground-water changes associated with the side-channel chute can influence cottonwood growth. Generally synchronous trends in growth rates, river discharge, and ground-water altitudes support the idea that water availability was a primary control on cottonwood growth (figs. 3, 4). Increased growth rates adjacent to the chute during the early part of the season when discharges were relatively high support the idea that the side-channel chute was a source for enhanced ground-water recharge that resulted in increased cottonwood growth (figs. 5-8). Plots further from the channel had reduced growth rates during the same time period. Other spatial and temporal factors, including solar radiation, surficial geology, and density of stems in the plots, appear to have had secondary influences on growth rates.
Stem growth rates, averaged over all trees in the survey, showed an initial increase in late June, followed by a nearly steady decline toward an asymptote near zero, or slightly negative values, in early September (fig. $3 A$ ). The timing of the cessation of basal area growth is consistent with other studies that examined height growth in cottonwood seedlings. Pezeshki and Oliver (1985), for example, found that 88 percent of height growth in black cottonwood (Populus trichocarpa) seedlings occurred by late July.

The trend in decreasing growth rates is parallel to the general trend in decreasing river discharge and ground-water levels (fig. 3 and this volume, chapter 3). River discharge declined gradually throughout the summer. Water altitude in the side-channel chute averaged $174.2 \mathrm{~m}$ from June 21 to August 8, and the average declined to $173.2 \mathrm{~m}$ from August 8 to September 21. Small floods interrupted this general trend; some of the floods were associated with local rainfall and some originated from rainfall upstream (fig. $3 B$ ). The most notable floods were in mid-June, just before we began to record growth rates, and August 24 to September 9 at the end of the experiment. Growth rates do not show any clear relation to air temperature or solar radiation events, which were highly variable during this time period. Incident solar radiation and average air temperature both show slight decreasing trends as would be expected from mid- to late-summer.

The three increases in growth rates during the study could correspond to transient increases in ground-water altitude or to local rainfall. It may be that the three distinct peaks in growth rates (G1-G3 on fig. 3A) are lagged responses to small rainfall and flood events (and subsequent ground-water recharge) in 

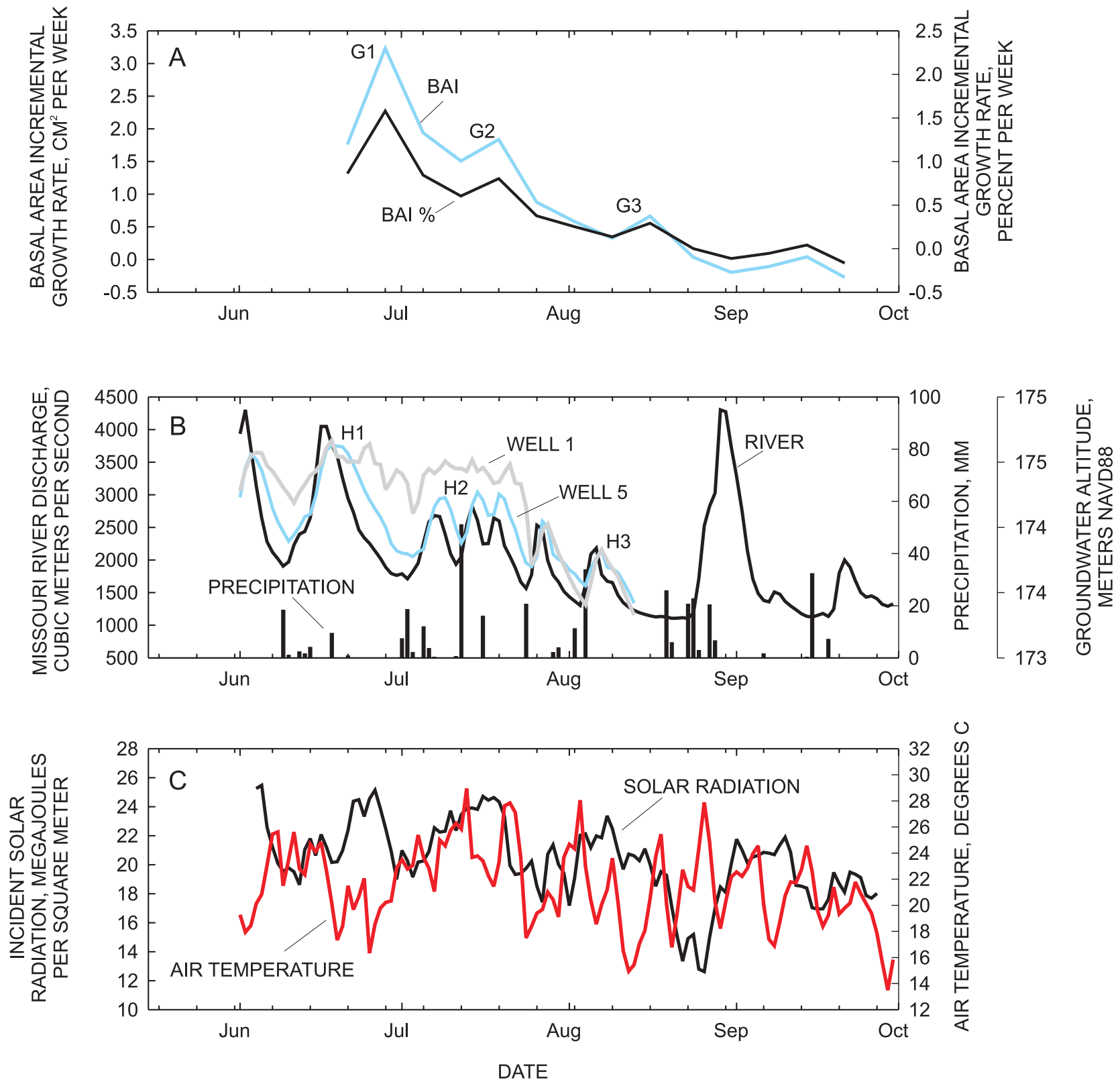

Figure 3. Average cottonwood growth rates and environmental variables. A. Total basal area increment and percent basal area increment weekly averages of all trees, all plots. G1-G3 mark correlated cottonwood growth events. B. River discharge at USGS stream-gaging station, number 06909000, Boonville, Missouri (USGS, 2005), ground-water altitudes in wells 1 and 5 (Kelly, this volume, chapter 3), and daily precipitation at Sanborn Field, Columbia, Missouri (University of Missouri, 2005). H1-H3 mark specific hydrologic events. C. Solar radiation and air temperature at Sanborn Field, Columbia, Missouri (University of Missouri, 2005). 


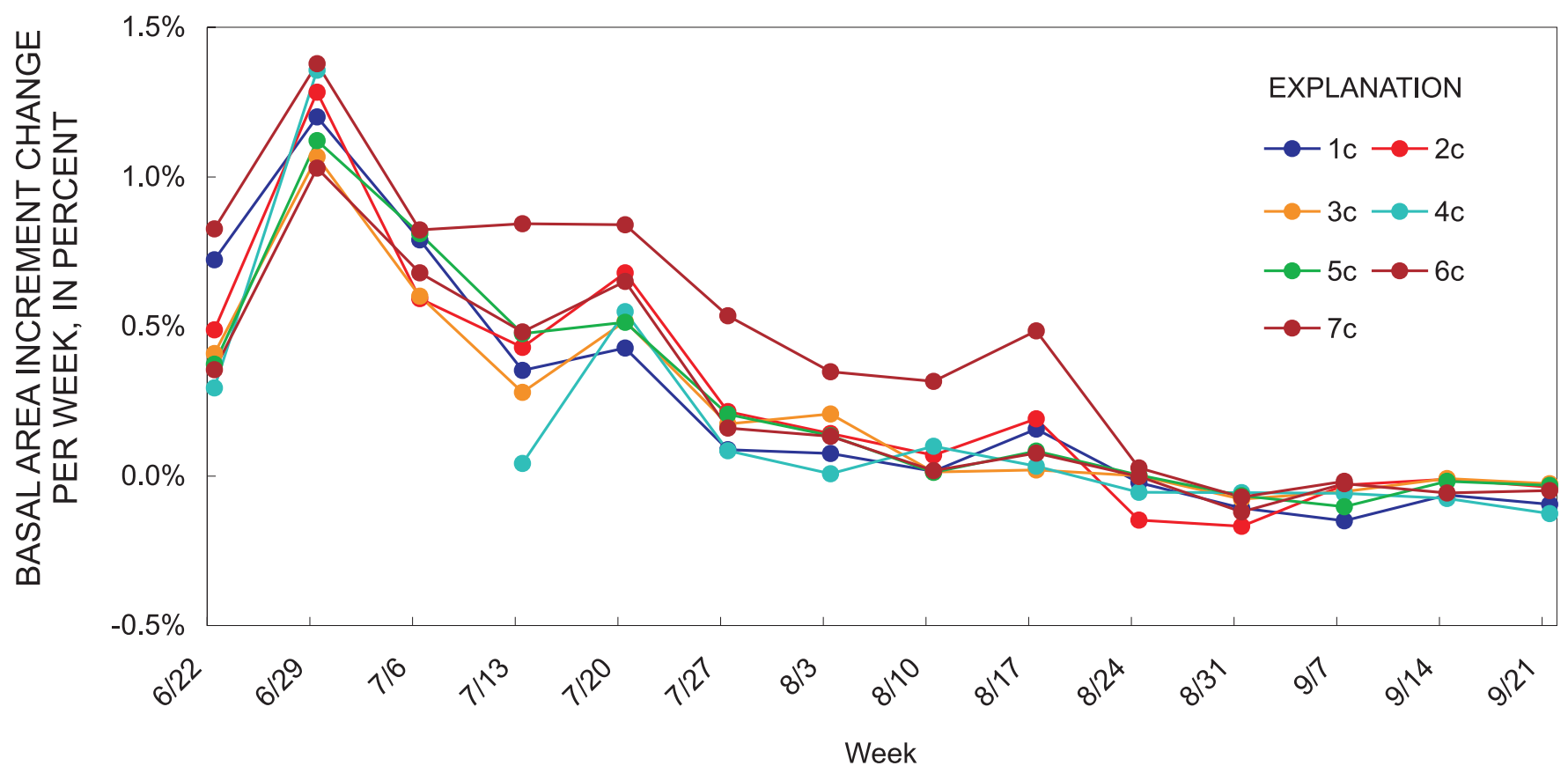

Figure 4. Growth rates of cottonwood by week for all plots on the central transect showing broadly synchronous trends.

mid-June, early-July, and early-August (H1-H3 on fig. $3 B$ ). Although it is impossible to separate the specific effects of local rainfall and river discharge in our dataset, the magnitude and timing of growth spikes appear to correlate better with river- and ground-water peaks than with local rainfall. A growth peak corresponding to the August 24-September 9 flood is notably absent. The trees were probably finished with basal area growth by late August (Pezeshki and Oliver, 1985).

The transient increases in growth rates would be consistent with the idea that cottonwood communities at Overton Bottoms North were undergoing water stress due to lowering of the ground-water altitude. Increased water stress led to lower basal growth rates as stomata closed and photosynthesis was limited by lack of $\mathrm{CO}_{2}$. Transient increases in groundwater levels temporarily revived growth rates, as increased stomatal conduction allowed increased passage of $\mathrm{CO}_{2}$ into the leaves (Pallardy and Kolowski, 1981).

Ground-water levels never fell below expected maximum rooting depths of cottonwood trees during this experiment. Two-year old black cottonwood seedlings, for example, have been found to have rooting depths of over $3 \mathrm{~m}$ and maximum rooting depths probably exceed $7 \mathrm{~m}$ (Pregitzer and Friend, 1996). These values are within the maximum depth of ground water $(4.68 \mathrm{~m})$ found at all well sites on the island at Overton Bottoms North (this volume, chapter 3). Although some roots probably maintain contact with ground water, trees typically have higher densities of roots in the upper levels of soil. For example, it is estimated that 80 percent of hybrid cottonwood roots were only 5 to $20 \mathrm{~cm}$ below the soil surface (Pregitzer and Friend, 1996). Thus it is probable that the higher ground- water levels maintained adequate soil-water conditions in zones of higher root density, thereby allowing for higher water and carbon uptake.

Growth rates showed complex spatial and temporal relations to geomorphic position, surficial geology, and site hydrology (figs. 5-7). In all three transects, growth rates were increased closer to the water source (the side-channel chute or the Missouri River) during the early part of the experimental period, with the exception of $4 C$ and $1 E$. During August and September, growth rates became more uniform and low along the transects, in some cases declining at sites closer to the water source. Temporal variability in growth rates is also evident when plot locations are evaluated by distance to the closest water source (side-channel chute or Missouri River, fig. $8 A-C)$. In general, these relations support the concept of an edge effect, in which the dominant influence of the side-channel chute is enhancement of tree growth through recharge of ground water during high river and chute discharge, and perhaps diminished growth rates during periods of low discharge when the side-channel chute acts to increase ground-water drainage.

Changes in ground-water altitudes lag behind surfacewater altitudes and thereby tend to buffer surface-water influences (fig. $3 B$ and this volume, chapter 3 ). During periods when surface-water altitudes in the side-channel chute and river were high, ground-water altitudes declined away from the river, possibly explaining the gradient of higher growth rates closer to the water source (fig. 6). In contrast, during periods when surface-water altitudes in the side-channel chute and river were low, ground water was "mounded" at higher 

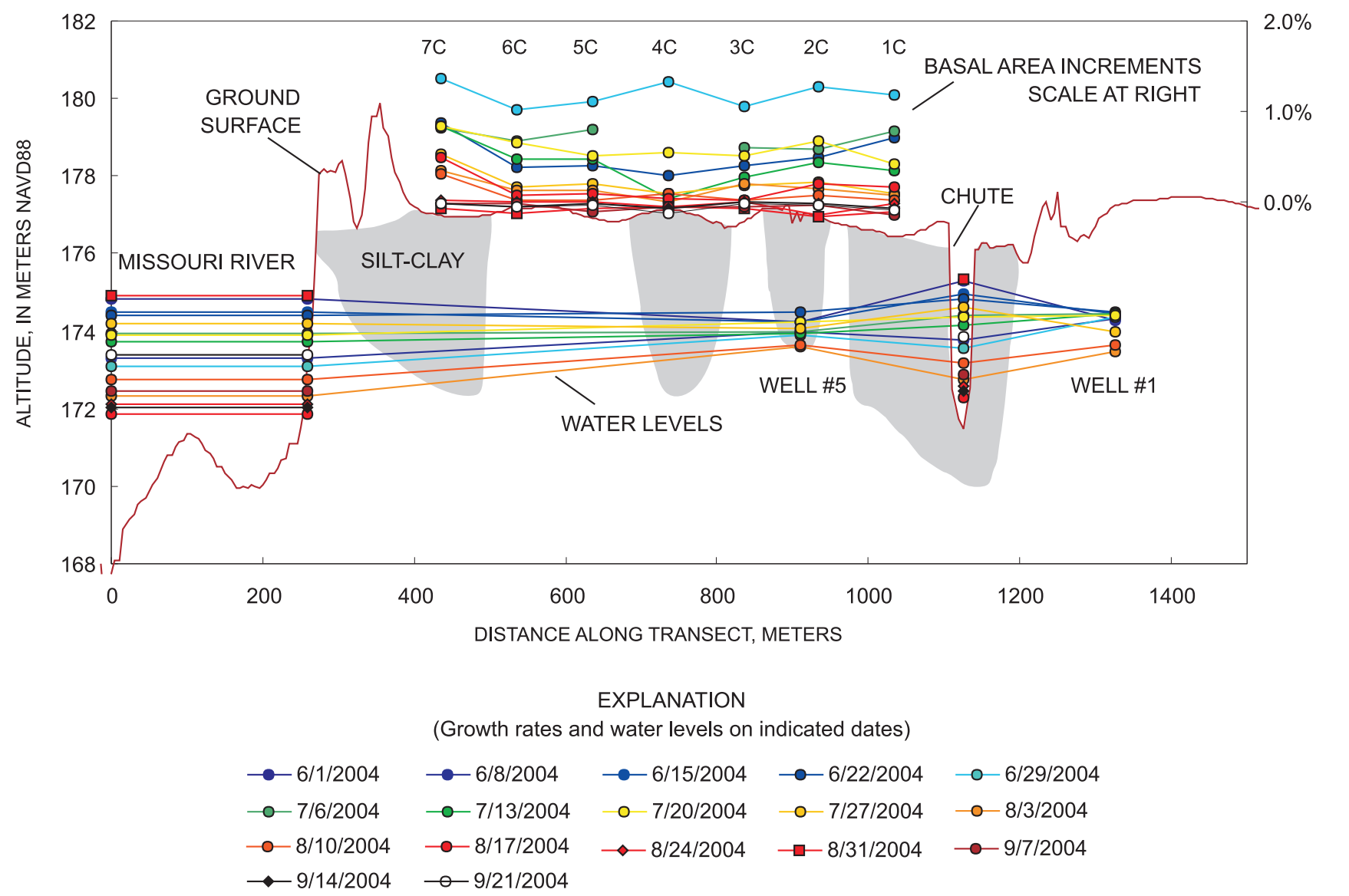

Figure 5. East transect, showing water levels and weekly cottonwood growth rates (basal area increment as percent). Section is oriented looking downstream. Colors for water levels and growth rates generally correspond to date, with June water levels and growth rates depicted in cool (blue and green) colors, changing toward warm colors (yellow to red to black) for late summer to fall dates. Silty-clay sediments indicated are fine channel-fill sediment from Holbrook and others, this volume, chapter 2. Sediments between and below the silty-clay channel fills are dominantly sand.

altitudes in the alluvium, possibly explaining the lower growth rates of trees near the water source (figs. 6, 8).

Some of the spatial variation in growth rates may be explainable by variation in soils and surficial geology along the transects. As indicated in figures 5-7 and discussed in this volume, chapter 2, fine-grained (silt-clay) surficial geologic units (channel-fill allounits) occur preferentially in swales whereas sandy units (point-bar allounits) underlie ridges. The combination of surficial geology and spatially variable ground-water influence potentially confounds interpretation of the role of the side-channel chute. For example, elevated growth rates at the ends and in the middle of the central transect (fig. 6) could relate in part to fine-grained soils that would have higher moisture-holding capacity. Surficial geologic controls are not as apparent on the east and west transects, however. We believe that the surficial geology is potentially a second-order influence on growth rates compared to ground- water altitudes. The relative influence of these factors cannot be assessed further with our available datasets.

The spatial trends in growth rate also do not appear to be the result of varying vegetation competition among the plots. There were two other tree species found on the plots: black willow and boxelder (Acer negundo). Basal area of all trees in the plot ranged from $70 \mathrm{~m}^{2} /$ ha to $160 \mathrm{~m}^{2} / \mathrm{ha}$, averaging 105 $\mathrm{m}^{2} /$ ha, with over 95 percent of this basal area cottonwood. The number of trees/ha ranged from 1,200 to 7,400 individuals/ha.; over 75 percent of these individuals were cottonwood. The mean number of trees/ha was 3,400. Growth rates generally increased as the number of trees/ha increased (fig. 5-9). The near-linear increase in growth rate with increase of stem density is inconsistent with intra- or inter-specific competition for light or other resources. This indicates that spatial variation in growth rates is unlikely to be related to variation in biotic interactions along the transects, and is much more likely to relate to site characteristics. 


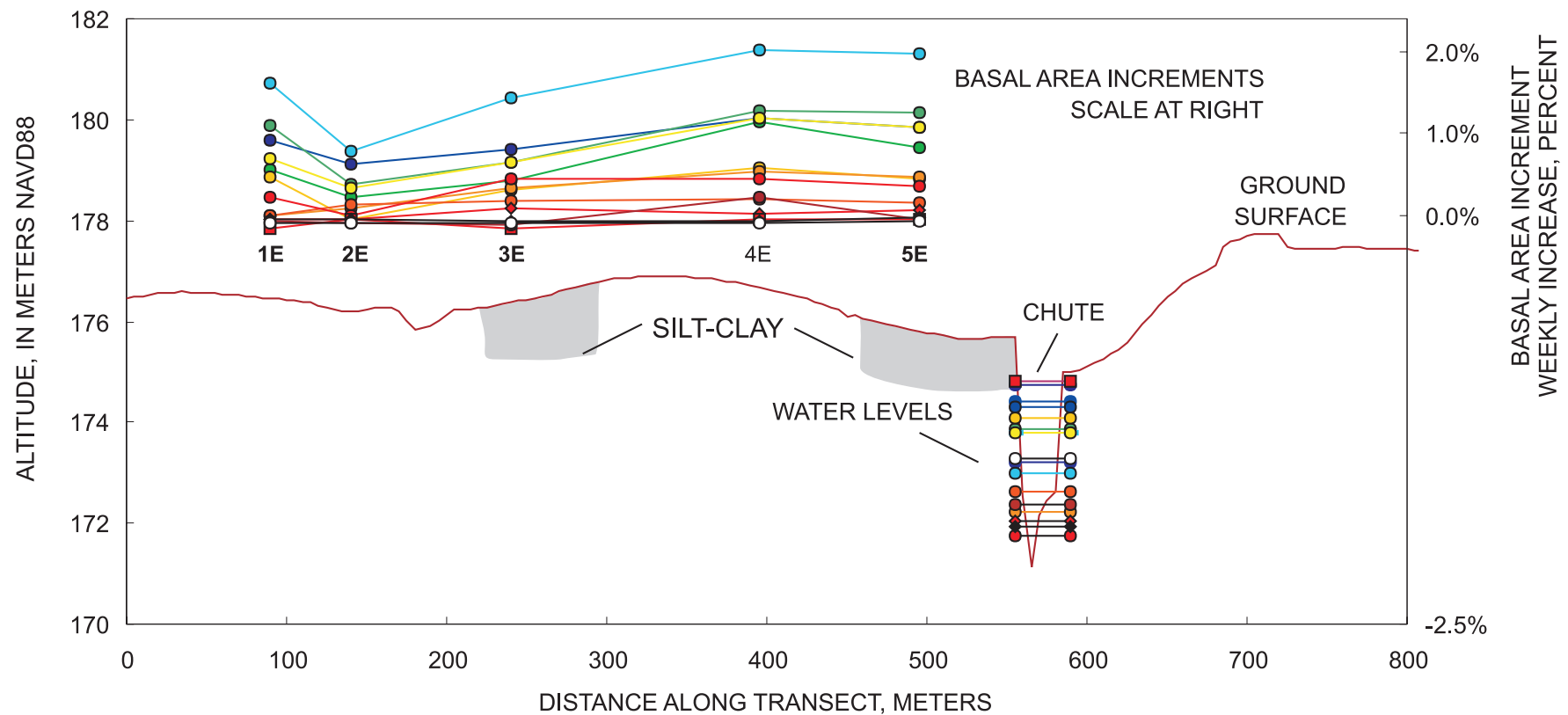

EXPLANATION

(Growth rates and water levels on indicated dates)
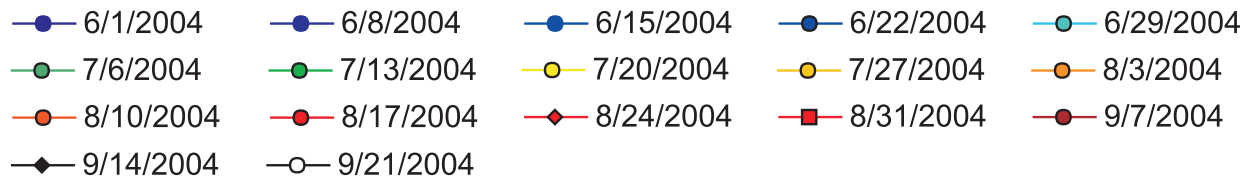

Figure 6. Central transect, showing water levels and weekly cottonwood growth rates (basal area increment as percent). Section is oriented looking downstream. Colors for water levels and growth rates generally correspond to date, with June water levels and growth rates depicted in cool (blue and green) colors, changing toward warm colors (yellow to red to black) for late summer to fall dates. Silty-clay sediments indicated are fine channel-fill sediment from Holbrook and others, this volume, chapter 2. Sediments between and below the silty-clay channel fills are dominantly sand.

The association between cottonwood growth rates and ground-water levels might be explained in part by increased nutrient availability associated with the water rather than being a direct effect of water on transpiration. Several authors have suggested that nitrogen availability can be a substantial limit to cottonwood growth (Woolfolk and Friend, 2003; Coleman and others, 2004). Cottonwood growth in plantations, for example, has been found to correspond positively to nitrogen additions (Woolfolk and Friend, 2003). Under natural conditions, Harner and Stanford (2003) found that cottonwood growing in the gaining reach of a stream had twice the basal area of cottonwood growing in the upstream losing reach. They attributed this to greater nutrient concentration in the gaining reach where microbially-enhanced, nutrient-rich water came to the surface. We did not measure nutrients associated with surface and ground water for this study. Because the study transects are far from the valley wall and poorly connected to upland drainage by either surface- or ground-water flow paths, the Missouri River is the only substantive potential nutrient source. We believe that the generally high nutrient availability in midwestern rivers like the Missouri (Mitsch and others, 2001) indicates that it is unlikely that nutrients are a limiting factor in cottonwood growth.

Another possibility is that growth rates responded to other variables that we did not measure. Consistency of time trends in growth rates among all plots (fig. 4) supports the idea that the primary factors affecting growth rate variability were relatively uniform across the plots. This broadscale consistency points to hydrologic or climatic factors as the primary controls, although these broad-scale factors may be mediated by plot-specific factors. However, the temporal patterns of growth were not clearly related to precipitation events or variability in temperature and solar radiation (fig. $3 A, 3 C$ ). Spatial variations in growth rates relative to distance to water source support the inference that growth rates related directly to ground-water altitude. Ground water remains as the variable 


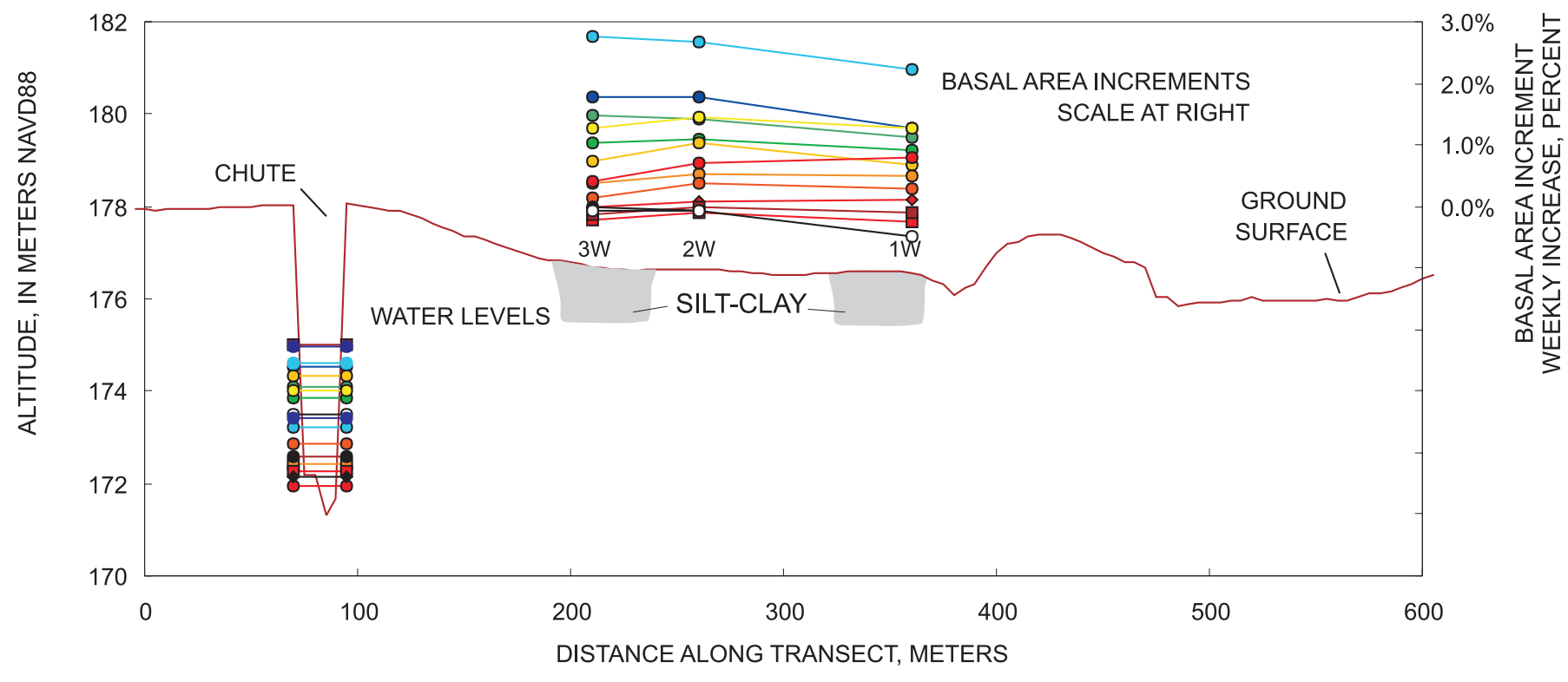

EXPLANATION

(Growth rates and water levels on indicated dates)

\begin{tabular}{|c|c|c|c|c|}
\hline$\longrightarrow 6 / 1 / 2004$ & $\longrightarrow-6 / 8 / 2004$ & $\rightarrow-6 / 15 / 2004$ & $\rightarrow-6 / 22 / 2004$ & - $-6 / 29 / 2004$ \\
\hline$-7 / 6 / 2004$ & $-0-7 / 13 / 2004$ & o $7 / 20 / 2004$ & - $-7 / 27 / 2004$ & $-0-8 / 3 / 2004$ \\
\hline$-0-8 / 10 / 2$ & - 8/17/2004 & $\diamond-8 / 24 / 2004$ & $\square-8 / 31 / 2004$ & $\multimap-9 / 7 / 2004$ \\
\hline , & - & & & \\
\hline
\end{tabular}

Figure 7. West transect, showing water levels and weekly cottonwood growth rates (basal area increment as percent). Section is oriented looking downstream. Colors for water levels and growth rates generally correspond to date, with June water levels and growth rates depicted in cool (blue and green) colors, changing toward warm colors (yellow to red to black) for late summer to fall dates. Silty-clay sediments indicated are fine channel-fill sediment from Holbrook and others, this volume, chapter 2 . Sediments between and below the silty-clay channel fills are dominantly sand.

most likely to explain both temporal and spatial trends we observed in cottonwood growth rates.

The effects noted in this field experiment should be interpreted within the context of the long-term hydrologic variability of this portion of the Lower Missouri River. The summer of 2004 was relatively wet and characterized by large fluctuations in discharge (fig. 10); the discharge was commonly greater than the long-term daily median and events in mid-late May and late-July exceeded the 10th percentile of flow for that time of year. Although our results indicate that the side-channel chute provided enhanced ground-water recharge and consequent increases in cottonwood growth rates during this study, these results should not be extended to predict effects in a lowdischarge year. Low-water conditions during this study only occurred after significant growth had stopped, so the effects of low water during the early part of the growing season cannot be assessed. Possibly, low water during the early part of the growing season might have had the opposite "edge effect" in which water stress and low growth would be more prevalent adjacent to the side-channel chute. Alternatively, in years with extended periods of high discharge, the chute could reduce cottonwood growth due to root hypoxia, which limits water uptake in plants. Results of ground-water monitoring over a multi-year timeframe (this volume, chapter 3) indicate that the overall trend has been for the side-channel chute to lower ground-water altitudes.

\section{Conclusions}

The results from this study support the hypothesis that during periods of high-river flow, the side-channel chute recharges ground water and enhances cottonwood growth. Cottonwood growth was found to be higher in plots closer to the river or side-channel chute. Cottonwood growth followed the decline of river and ground-water altitudes, and periods of increased water height were followed by periods of increased 


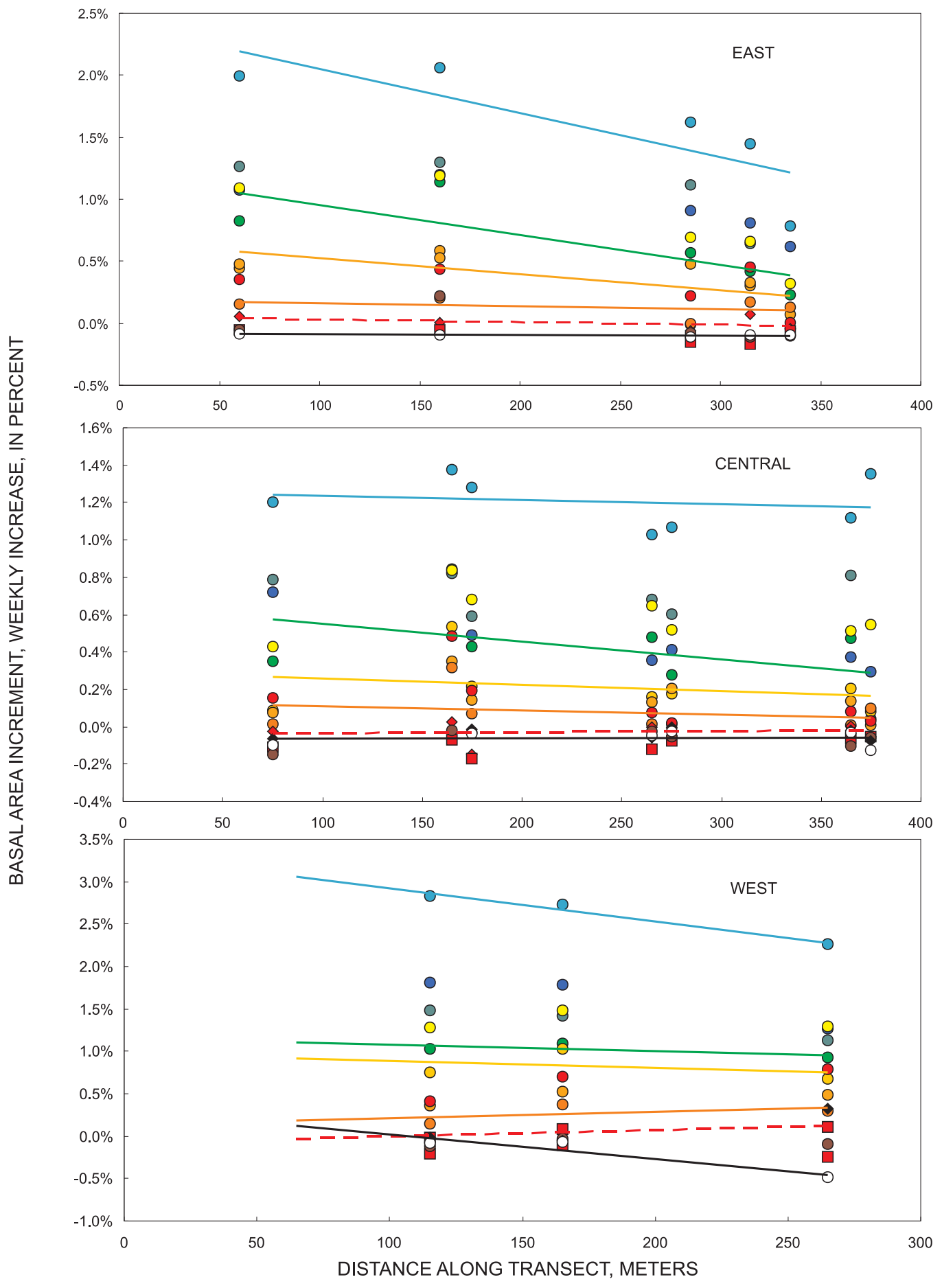

\section{EXPLANATION}

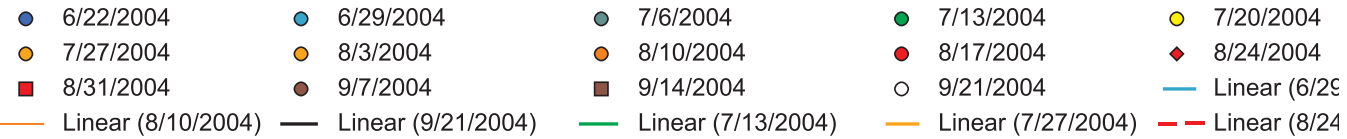

Figure 8. Basal area incremental growth rates as a function of distance from the nearest water source, either the Missouri River channel or the side-channel chute. Linear regression model lines are shown for approximately every other week to illustrate trend from higher growth rates nearest the water source early in the season to spatially uniform low rates late in the season. 


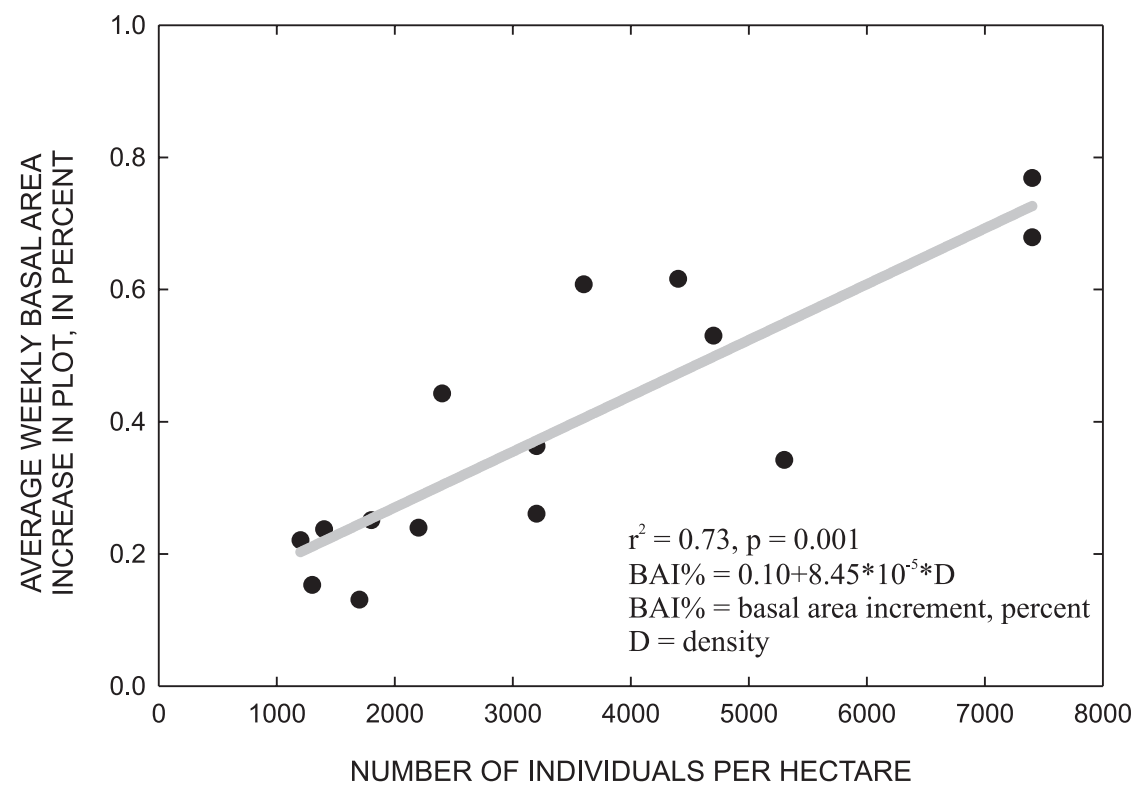

Figure 9. Relation between growth rate and density of individual trees in plots. The increase in growth rate with increasing density indicates a dominant site environmental control on growth rates rather than a light competition effect, which would have a inverse relation.

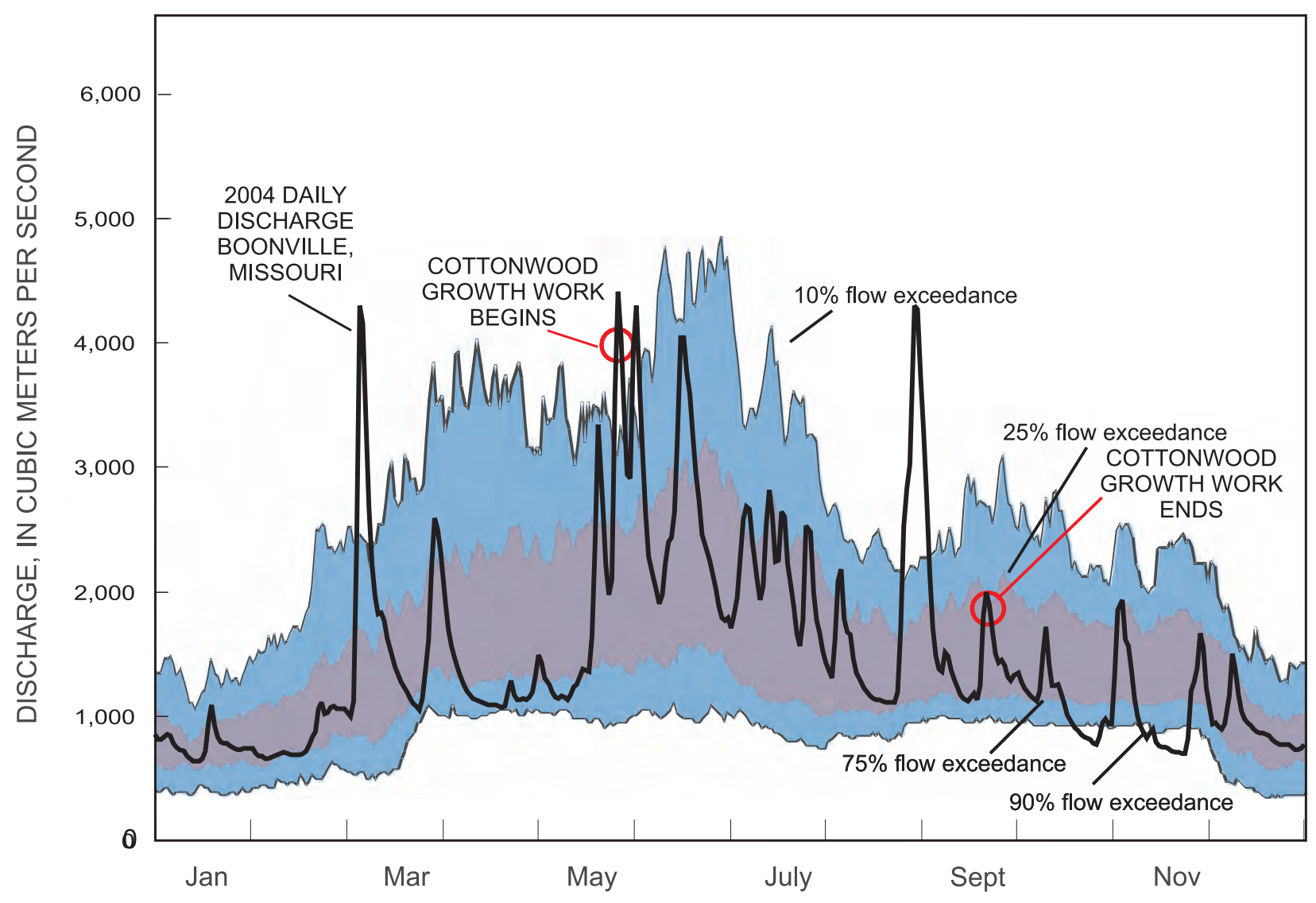

Figure 10. Missouri River discharge during 2004 compared to historical flow durations. 2004 was a relatively wet year, with daily discharges exceeding the 25 percent flow exceedance multiple times during the growing season. 
cottonwood growth. In addition, variation in cottonwood growth could not be attributed to differences in air temperature, solar radiation, or competition for light.

Conclusions drawn from this study need to be considered in the context that the study occurred only for one, unusually wet season. The following year, 2005, the Missouri River basin experienced an extensive drought which could have altered the results of this study. For example, low river discharge may have resulted in the plots closest to the channel having the lowest growth rates due to the "edge" effect. However, the general conclusion that the side-channel chute is instrumental in altering ground-water levels and affecting cottonwood water relations would still be valid.

The side-channel chute was designed to provide more shallow-water habitat in the Missouri River flood plain, mainly to promote recovery of native and endangered aquatic species. While the alteration of ground-water flow has the potential to adversely affect riparian vegetation communities, this study indicates that there is not necessarily an acute trade-off between management of aquatic and riparian species. In this case, it is apparent that a side-channel chute can alter flood-plain hydrology in ways that have positive effects on growth rates of riparian cottonwood communities.

\section{References Cited}

Albertson, F.W., and Weaver, J.L., 1945, Injury and death or recovery of trees in prairie climate: Ecological Monographs, v. 15 , p. $393-433$.

Auble, G.T., and Scott, M.L., 1998, Fluvial disturbance patches and cottonwood recruitment along the Upper Missouri River, Montana: Wetlands, v. 18, p. 546-556.

Bloom, A.J., Chapin, F.S., III, and Mooney, H.A., 1985, Resource limitation in plants-an economic model: Annual Review of Ecology and Systematics, v. 16, p. 363-392.

Brinson, M.M., 1990, Riverine Forests, in, Lugo, A., Brinson, M., and Brown, S., eds., Forested Wetlands: New York, NY, Elsevier, p. 87-141.

Burns, R.M., and Honkala, B.H., 1990, Silvics of North America, part 2, hardwoods: Washington D.C., U.S. Department of Agriculture Handbook 654, 877 p.

Cattelino, P.J., Becker, C.A., and Fuller, L.G., 1986, Construction and installation of homemade dendrometer bands: Northern Journal of Applied Forestry, v. 3, p. 73-75.

Coleman, M.D., Friend, A.L., and Kern, C.C., 2004, Carbon allocation and nitrogen acquisition in a developing Populus deltoides plantation: Tree Physiology v . 24, p. 1347-1357.
Decamps, H., 1997, The renewal of floodplain forests along rivers-a landscape perspective: Verh. Internat. Verein. Limnol., v. 26, p. 35-59.

Harner, M.J., and Stanford, J.A., 2003, Differences in cottonwood growth between a losing and gaining reach of an alluvial floodplain: Ecology, v. 84, p. 1453-1458.

Johnson, R.L., 1965, Regenerating cottonwood from natural seedfall: Journal of Forestry, v. 63, p. 33-36.

Johnson, W.C., 1994, Woodland expansion in the Platte River, Nebraska-patterns and causes: Ecological Monographs, v. 64, p. 45-84.

Johnson, W.C., 2002, Riparian vegetation diversity along regulated rivers-contribution of novel and relic habitats: Freshwater Biology, v. 47, p. 749-759.

Karrenberg, S., Edwards, P.J., and Kollmann, J., 2002, The life history of Salicaceae living in the active zone of floodplains: Freshwater Biology, v. 47, p. 733-748.

Keyes, M.R., and Grier, C.C., 1981, Above- and below-ground net production in 40-year-old Douglas-fir stands on low and high productivity sites: Canadian Journal of Forest Research, v. 11, p. 599-605.

Kozlowski, T.T., and Pallardy, S.G., 1997, Physiology of woody plants: San Diego, Calif., Academic Press, 399 p.

Kramer, P.J., and Boyer, J.S., 1995, Water relations of plants and soils: San Diego, Calif., Academic Press, 495 p.

Mitsch, W.J., Day, J.W., Jr., Gilliam, J.W., Groffman, P.M., Hey, D.L., Randall, G.W., and Wang, N., 2001, Reducing nitrogen loading to the Gulf of Mexico from the Mississippi River Basin-strategies to counter a persistent ecological problem: Bioscience, v. 51, p. 373-388.

Mitsch, W.J., and Gosselink, G.J., 2000, Wetlands, 3rd edition: New York, John Wiley \& Sons, Inc., 920 p.

Pallardy, S.G., and Kozlowski, T.T., 1981, Water relations of Populus clones: Ecology, v. 62, p. 159-169.

Pezeshki, S.R., and Oliver, C.D., 1985, Early growth patterns of red alder and black cottonwood in mixed species plantations: Forest Science, v. 31, p. 190-200.

Pregitzer, K.S., and Friend, A.L., 1996, The structure and function of Populus root systems, in Steller, R.F., ed., Biology of Populus and its implications for management and conservation: Ottawa, Ontario, NRC Research Press, p. $331-354$.

Reily, P.W., and Johnson, W.C., 1982, The effects of altered hydrologic regime on tree growth along the Missouri River in North Dakota, USA: Canadian Journal of Botany, v. 60, p. 2410-2423. 
Rood, S.B., and Mahoney, J.M., 1990, Collapse of riparian poplar forests downstream from dams in western prairiesprobable causes and prospects for mitigation: Environmental Management, v. 14, p. 451-464.

Scott, M.L., Auble, G.T., and Friedman, J.M., 1997, Flood dependency of cottonwood establishment along the Missouri River, Montana, USA: Ecological Applications, v. 7, p. 677-690.

Scott, M.L., Lines, G.C., and Auble, G.T., 2000, Channel incision and patterns of cottonwood stress and mortality along the Mojave River, California: Journal of Arid Environments, v. 44 , p. $399-414$.

Segelquist, C.A., Scott, M.L., and Auble, G.T., 1993, Establishment of Populus deltoides under simulated alluvial groundwater declines: American Midland Naturalist, v. 130, p. 274-285.

Shafroth, P.B., Stromberg, J.C., and Patten, D.T., 2002, Riparian vegetation response to altered disturbance and stress regimes: Ecological Applications, v. 12, p. 107-123.

Tyree, M.T., Kolb, K.J., Rood, S.B., and Patino, S., 1994, Vulnerability to drought-induced cavitation of riparian cottonwoods in Alberta-a possible factor in the decline of the ecosystem: Tree Physiology, v. 14, p. 455-466.

U.S. Geological Survey, 2005, National water quality information system: Reston, Va., U.S. Geological Survey, accessed 2005, at URL http://waterdata.usgs.gov/mo/nwis/uv/?site no $=06909000$.

University of Missouri, 2005, Missouri agricultural weather: Columbia, Mo., University of Missouri Atmospheric Science Department at the College of Agriculture, Food and Natural Resources, accessed 2005, at URL http://agebb. missouri.edu/weather.

Woolfolk, W.T.M., and Friend, A.L., 2003, Growth response of cottonwood roots to varied $\mathrm{NH}_{4}: \mathrm{NO}_{3}$ ratios in enriched patches: Tree Physiology, v. 23, p. 427-432. 


\section{Implications for Adaptive Habitat Management of the Overton Bottoms North Unit, Big Muddy National Fish and Wildlife Refuge, Missouri}

By Carol A. Finn and Robert B. Jacobson

Chapter 6 of

Science to Support Adaptive Habitat Management: Overton Bottoms

North Unit, Big Muddy National Fish and Wildlife Refuge, Missouri

In cooperation with the U.S. Fish and Wildlife Service

Scientific Investigations Report 2006-5086

U.S. Department of the Interior

U.S. Geological Survey 


\section{Contents}

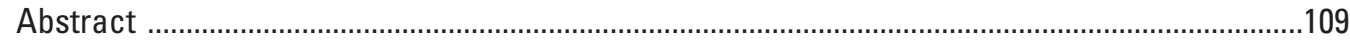

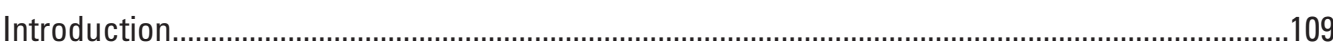

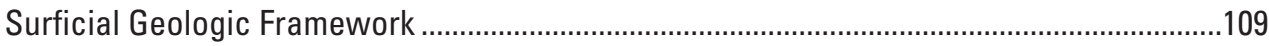

Hydrologic Framework and Responses to Reconnection of the Flood Plain........................110

Land Cover Responses to Hydrologic Reconnection ........................................................110

Cottonwood Growth Responses to Hydrologic Alteration ....................................................111

Scientific Investigations and Adaptive Management of the Missouri River Flood Plain ..............111

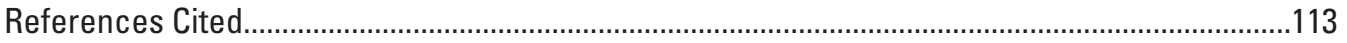

Suggested citation:

Finn, C.A., and Jacobson, R.B., 2006, Implications for adaptive management of the Overton Bottoms North Unit, Big Muddy National Fish and Wildlife Refuge, Missouri, chap. 6 of Jacobson, R.B., ed., Science to support adaptive habitat management-Overton Bottoms North Unit, Big Muddy National Fish and Wildlife Refuge, Missouri: U.S. Geological Survey, Scientific Investigations Report 2006-5086, p. 107-113. 


\title{
Implications for Adaptive Habitat Management of the Overton Bottoms North Unit, Big Muddy National Fish and Wildlife Refuge, Missouri
}

\author{
Carol A. Finn and Robert B. Jacobson
}

\section{Abstract}

Integrated, landscape-scale investigations of ecological responses to hydrologic reconnection of the flood plain at Overton Bottoms, Missouri, demonstrate the value of multidisciplinary approaches to adaptive management of flood-plain restoration. Surficial geologic mapping at Overton Bottoms North Unit documented the foundation of materials and topography that influence the spatial distribution of water on the flood plain. Surface and subsurface hydrologic investigations documented the temporal variability of hydrologic events affecting the flood plain, and how surficial geology and excavation of a side-channel chute influenced the spatial distribution of water. Decade-scale monitoring of vegetation community responses in flood-plain areas reconnected to the flood plain documented trends of increasing cottonwood/ willow patch area at the expense of weeds/forbs/grasses area. Comparison of trends in cottonwood/willow expansion with surficial geologic and hydrologic characteristics suggests patterns of colonization are systematically controlled by hydrology, and mediated by surficial geology and topography. A season-long experiment quantifying cottonwood growth rates adjacent to the chute demonstrated annual-scale sensitivity of vegetation communities to hydrologic alterations of the valley bottom. During a season of relatively high flow, cottonwood growth rates adjacent to the chute were frequently as much as two times faster than those located several hundred meters from the chute, presumably because ground-water recharge from the chute prevented soil moisture from being a growth-limiting factor. The integrated, landscape-scale understanding gained from these studies should provide useful information to guide design and management of similar rehabilitation projects in flood plains for large rivers.

\section{Introduction}

The Overton Bottoms area, Missouri, presented an opportunity to evaluate ecosystem responses of flood-plain rehabilitation in a field-scale experiment. The flood-plain area was opened to the Missouri River when levees broke in 1993 , and subsequent excavation of a side-channel chute increased the hydrologic connection between the flood plain and mainstem channel. This report presented an integrated analysis of interactions among geologic, hydrologic, and vegetation characteristics at the site. As a case study, the project provided some new insights into functions of flood-plain ecosystems; these insights will hopefully be tested, replicated, and refined at other sites. In addition, the studies provided specific information that should be useful for performance evaluation of the Overton Bottoms restoration project. In general, the study illustrated the value of scientific information in design and management of flood-plain rehabilitation projects.

\section{Surficial Geologic Framework}

Underlying sediments and topography determine much about how the river interacts with its flood plain, including how often it is flooded and how efficiently it retains water. Chapter 2 in this report documented the surficial flood-plain stratigraphy of the Overton Bottoms North Unit, evaluated geologic effects on physical and biotic processes, and suggested some implications for bottomland management. The results show that surficial geology of Missouri River valley bottoms presents a three-dimensional mosaic of sharply contrasting material properties that would be expected to have a strong effect on hydrologic characteristics, ecosystem processes, and habitat potential.

Detailed mapping and cross sections at Overton Bottoms North also provided understanding to inform models of how the Missouri River has changed during the late Holocene. Models of historical river changes can help define reference conditions to guide restoration activities. They also provide a conceptual framework for extending geologic mapping to other areas. Unlike wide valley segments upstream, the bedrock-bounded reach of the Missouri River in the Overton Bottoms area records only deposits from a relatively young, low-sinuosity, island-braided system. This recent geologic view of the river adds three-dimensional understanding of the reference condition to sparse historical information. 
The distribution of contrasting channel-fill and point-bar units identified at Overton Bottoms North has a potentially strong influence on interaction of surface and ground water. Generally, channel fills (channel-fill allounits) will be better at retaining surface water than point-bar allounits because they are relatively impermeable and occur in topographic depressions. Fine-grained, low-permeability strata in channel fills, however, can also diminish infiltration of surface water and recharge of the alluvial aquifer. Because of their topographic position and low permeability, channel-fill allounits have high potential for natural wetlands and would provide good opportunities for construction of engineered wetlands.

Where overlying top strata are thin, point-bar allounits can be areas of enhanced recharge to the alluvial aquifer. These units also are more prone to rapid infiltration and drainage, and will tend toward comparatively xeric species. Pointbar units do not have high potential for engineered wetlands, and they may present risks of increased contamination of the aquifer in the event of chemical spills.

\section{Hydrologic Framework and Responses to Reconnection of the Flood Plain}

Hydrologic assessment at Overton Bottoms North Unit (Chapter 3) quantified the effects of reconnection of the flood plain to the mainstem Missouri River. The Overton Bottoms reach provided a unique opportunity to evaluate hydrologic functions in the flood plain before and after side-channel chute construction, and after subsequent adaptive re-excavation of the chute. The objectives of the study were to quantify relations among river stage, chute stage, ground-water levels, and rainfall; and to quantify how hydrologic reconnection due to chute construction altered the hydrology at Overton Bottoms.

Monitoring of ground-water altitudes after the initial reconnection in 1993 demonstrated that ground water varied closely with river altitude at Overton Bottoms North. This is probably an inherent feature of Missouri River bottomlands resulting from the high permeability of sandy deposits, and would tend to occur even in bottomlands surrounded by levees. Breaching of levees and chute construction, however, served to enhance the coupling of surface and ground water. Because of a conservative initial design, water flow in the first-generation chute occurred less frequently than in the second-generation chute. Hence, effect of the first-generation chute on ground water was measurable, yet modest. The wider and deeper second-generation chute increased the interaction between surface water and ground water because its geometry allowed water to flow through it most of the year and because the bottom of the chute was excavated into permeable sand units below the water table. Depth to ground water and variability of depth to ground water generally increased from the pre-chute condition, to the first-generation-chute conditions, and was greatest for second-generation-chute conditions at most monitoring wells. Between pre-chute and second-gen- eration-chute conditions, the median water level at several observation wells decreased $0.5-0.9 \mathrm{~m}$.

When water flows in the river were relatively high, the chute construction allowed the Missouri River to inundate Overton Bottoms more frequently and at a lower stage compared to the pre-chute condition. Prior to breaching of the levee, water flowed onto the flood plain about once every 10 years. After the levee was breached, water flowed onto the flood plain about three days per year on average. And, since construction of the second-generation chute, flow is present through the chute about 345 days per year. Increased hydrologic connection increased inundation of low-lying areas, recharge to wetlands, and variability of the ground-water table. During low-water conditions, however, the chute served to drain adjacent wetlands. Therefore, chute construction at Overton Bottoms North had the net effect of making wetlands drier during dry periods and wetter during and immediately after flood periods.

\section{Land Cover Responses to Hydrologic Reconnection}

Breaching of levees at Overton Bottoms during the 1993 flood and eventual conversion of much of the agricultural land to conservation purposes during 1993-2002 provided an opportunity to evaluate how valley-bottom vegetation communities would adjust to hydrologic reconnection under minimal management intervention (chapter 4). Landsat Thematic Mapper (TM) multispectral satellite image data were used to map generalized classes of vegetation and land cover on five different dates between September 1994 and September 2002. Ten mapped data sets documented how the vegetation communities changed over time: 5 classified images showed the land-cover classes for each year, 4 images showed the change in those classes from one date to the next, and 1 image documented the overall changes in the classes between 1994 and 2002. Each classified image also was analyzed for spatial characteristics of the vegetation classes to characterize patch dynamics.

The dominant change observed at Overton Bottoms 1994-2002 was expansion of willows and cottonwoods at the expense of former agricultural land that had grown into weeds/forbs/grasses. While the area of cottonwoods and willows increased by a factor of 10 (72 ha to 702 ha) during this period, the increase was not uniform. Growth was most pronounced in low-lying areas adjacent to the river where depth to ground water was shallow and soils were relatively moist. In these low-lying flood-plain areas surficial geologic units seemed to have little control on the size and shape of cottonwoods/willows expansion areas.

On higher alluvial surfaces, growth of the cottonwoods/ willows class was more strongly controlled by surficial geology. Cottonwoods/willows growth was concentrated in channel-fill allounits as identified and mapped in chapter 2. 
The channel fills presumably have greater retention of soil moisture than surrounding point-bar areas, and therefore provide somewhat more amenable conditions for germination and growth of cottonwoods/willows seedlings. In contrast, the permeability and structure of adjacent point-bar allounits in this area limits water availability.

The documented temporal trends suggest that the cottonwoods/willows class will continue to increase in area, although at a decreasing rate. Trends of patch characteristics also suggest that mean core area and total edge will continue to increase. As discussed in chapter 4, these patch characteristics may affect habitat quality for wildlife. The correspondence between cottonwoods/willows patches and channel-fill geologic units suggests that the surficial geology template will lead to persistent, arcuate patches of cottonwoods/willows if natural colonization processes are not interrupted.

\section{Cottonwood Growth Responses to Hydrologic Alteration}

The study in Chapter 5 assessed the direct effect of the second-generation side-channel chute on cottonwood growth at the Overton Bottoms North Unit. Growth rates were assessed using dendrobands that were placed on 75 trees across three transects oriented perpendicular to the chute. Growth was measured each week June-September, 2004, during a period characterized by somewhat wetter-than-usual conditions. The experimental design was intended to explore the question of whether the chute's evident effect on groundwater altitude (as documented in chapter 3 ) serves to enhance or diminish cottonwood growth.

Cottonwood growth was found to be higher in plots closer to the river or side-channel chute. Moreover, growth appeared to fluctuate with hydrologic condition: periods of increased water flow were associated with periods of increased cottonwood growth. During the latter part of the growing season, cottonwood growth followed the decline of river and the ground-water table. Although the period of monitoring was relatively short, these results support the hypothesis that during periods of high river flow, the side-channel chute recharges ground water and enhances cottonwood growth. Variation in cottonwood growth could not be attributed to differences in other factors like air temperature, solar radiation, or competition for light.

The side-channel chute was designed to provide more shallow-water habitat in the Missouri River corridor, mainly to promote recovery of native and endangered aquatic species. While the alteration of ground-water flow has the potential to adversely affect riparian wetland communities during dry periods, this study indicated that during wet periods the opposite can happen. Hence, the results suggest that there is not necessarily an acute trade-off between management of aquatic and riparian species in which enhancement of habitat for one necessarily diminishes habitat for the other. Monitoring over a longer period would be necessary to establish long-term effects of the chute on growth rates and woody community structure.

\section{Scientific Investigations and Adaptive Management of the Missouri River Flood Plain}

Our scientific investigations at Overton Bottoms opportunistically used a flood-plain rehabilitation project as a field-scale quasi-experiment. The experiment yielded new insights into landscape-scale ecological responses and generated hypotheses for additional testing. The experiment, in turn, also provided new understanding that should be highly applicable to adaptive management of rehabilitation projects in the Missouri River flood plain. In particular, the experiment demonstrated how surficial geology and hydrology create the fundamental mosaic of habitat potential on a typical bottomland. Documentation of how hydrology, vegetation patterns, and cottonwood growth rates have been altered and continue to change as a result of rehabilitation indicates how the project has performed and whether it is likely to meet long-term project objectives. We believe that this integrated understanding also will be useful to inform land acquisition decisions, and design and management of similar projects.

Surficial alluvium and its topographic expression mediate the distribution of water (and therefore energy and nutrients) in the Overton Bottoms flood plain. It follows that understanding of the geologic, topographic, and hydrologic framework of a bottomland site provides substantial information on the characteristics of habitat that can be supported on the site. For example, surficial alluvium maps depict the spatial distribution of sediments with a wide range of potential for inundation, and for transmitting and retaining water. Recognition of the characteristics and spatial patterns of these sediment units could be useful in design of wetlands and alignments of side-channel chutes. In the case of wetlands, design of wetland cells along water-retaining channel-fill allounits would result in arcuate wetland areas that would mimic those of the natural flood plain and would be inherently more efficient at retaining water than cells arcuated across permeable units. In the case of side-channel chute alignments, recognition of locations, sediment characteristics, and thickness of channel-fill allounits should provide useful information for alignments and channel dimensions. In particular, understanding of sediment distributions would be important for designing whether water in the chute is purposefully isolated from adjacent valley-bottom alluvium, or whether excavations extend into permeable sediments to enhance transmission of water into the alluvial aquifer. Understanding of the distribution of sediment properties would also be useful in predicting costs of chute construction and whether a side-channel chute is likely to migrate rapidly or slowly. For example, if the design objective for a chute is to 
promote dynamic aquatic habitats by encouraging rapid lateral erosion and migration, the alignment should avoid channel-fill allounits that would have sediment with higher resistance to erosion compared to point-bar allounits.

Hydrologic responses to reconnection of Overton Bottoms North with the Missouri River demonstrate some of the trade-offs inherent in side-channel chute constructions. In the pre-chute condition, Overton Bottoms North was connected to the river through breached levees during overbank flooding events. Without a chute to enhance ground-water and surfacewater drainage, ground-water altitudes remained high and water drained slowly from the flood plain whenever overbank floods occurred. The first-generation chute increased aquatic habitat availability in the chute itself and increased the number of flow events that connected with the flood plain. At the same time, the first-generation chute also decreased ground-water altitudes during low-flow conditions, resulting in enhanced drainage of wetlands. This affect was increased for the deeper, wider second-generation chute. This result indicates that land managers should be aware of the potential trade-off between gains to aquatic habitats and losses of wetlands.

Integrated effects of hydrologic reconnection and the surficial alluvium framework were observed in the retrospective analysis of vegetation community classes. The remotely sensed observations from 1994-2002 captured mainly effects of relatively passive vegetation management wherein natural processes of succession and expansion were allowed to occur. This passive approach would presumably minimize cost to land managers, but may not achieve specific management goals such as habitat enhancement for particular species or elimination of invasive species. The results document that the cottonwoods/willows class increased in extent, core area, and total edge, especially in low-lying areas adjacent to the river channel, whereas in higher parts of the valley bottom, the cottonwoods/willows class expanded preferentially into areas mapped as channel-fill allounits. Under passive management, arcuate patches of cottonwoods/willows will probably continue to expand along ancient channel fills in the higherelevation parts of the Overton Bottoms North, increasing total area of this vegetation class and total edge habitat. The cottonwoods/willows class has been slower to expand in pointbar allounits between the channel fills, presumably because of lower soil moisture in these landscape positions. This observation indicates that managers could target point-bar units preferentially to establish more xeric grass or tree species, while retaining channel fills for wetlands and mesic species.

The single-season study of cottonwood growth rates was a more specific assessment of the trade-off between aquatic habitat enhancement and potential degradation of terrestrial habitat: did the hydrologic gradients created by the side-channel chute have a measurable effect on growth rates of trees adjacent to the chute? Although it was hypothesized that the increased ground-water drainage adjacent to the chute would decrease growth rates, the opposite effect was documented as cottonwoods grew faster adjacent to the chute during the wet, early part of the growing season. Other potential factors-such as surficial geology and stand-density dependent growth-were discounted as insignificant. Although growth rates were actually increased as a result of the chute during this relatively wet season, declines in growth rates adjacent to the chute later in the season when river flows decreased also indicated that growth rates could be sensitive to low flow conditions as well. These results confirm that woody vegetation growth can be affected by side-channel chutes, although the effect is not always negative. The implication for adaptive management of bottomland resources is that side-channel chutes can be expected to alter hydrologic gradients in ways that can be significant to adjacent vegetation communities. Chute alignments that minimize depth and excavation in highly transmissive sediment would minimize this effect.

The studies presented here may also be useful in setting a baseline for continued monitoring and evaluation of responses to rehabilitation. Long-term evaluations of rehabilitation projects are rare (Bernhardt and others, 2005; Downs and Kondolf, 2002) and the existing level of documentation at Overton Bottoms may be unprecedented. The hydrologic drivers at Overton Bottoms North can be expected to change over time as the morphology of the second-generation sidechannel chute adjusts to the discharge and characteristics of its bed and banks. The second-generation chute is relatively young (created in 2003) and geomorphic monitoring indicates that it is actively eroding and widening (Jacobson and others, 2004; Robert Jacobson, oral commun., 2005). Adjustments to the chute morphology will alter its effects on ground-water and surface-water connections and wetland distributions, as well as directly affecting flood-plain habitats by eroding and depositing new sediments. Changes to morphology also can be expected to change the hydrologic gradients adjacent to the chute, with consequent effects on vegetative growth rates and community structure. In addition, as shown in chapter 4, vegetation community classes are continuing to change total extent and shape, and these successional and colonization trends can be expected to continue.

Whether these changes will be consistent with long-term management goals of the Overton Bottoms area is difficult to predict. However, these studies documented that the Overton Bottoms North ecosystem (as measured by physical habitat and vegetation variables) is continuing its dynamic trend of change that began in 1993. Continued monitoring of selected characteristics of this site would provide managers with additional information on what to expect as similar rehabilitation sites adjust to hydrologic reconnection. Such information may prove useful in aligning management goals with the inherent habitat potential of the landscape.

One important piece of information that would come from such monitoring are the typical rates of ecological change and consequently how long monitoring should be maintained. Design of effective long-term monitoring needs 
to balance information content and cost (Palmer and others, 2005). We recommend continued monitoring of fundamental drivers (hydrology) and first-order effects (geomorphic changes to the chute) complemented with monitoring of selected biological indicators. Biological indicators should have clear importance to management goals or ecosystem processes, and they should be chosen to minimize errors associated with sampling variability. Remotely sensed mapping of vegetation community changes is a relatively cost-effective means to monitor broad scale changes, although at modest spatial (30-m) and temporal (annual) resolution.

The USGS Lower Missouri River Central Region Integrated Science Program (CRISP) project was carried out to contribute integrated scientific assessments to adaptive management in the Missouri River corridor. The project has documented: (1) the fundamental role of surficial geology in determining habitat potential of the valley-bottom landscape, (2) connections among surface water, ground water, and wetlands, (3) influence of surficial geology and topography on vegetation community colonization patterns in passively managed bottomlands, and (4) enhancement of cottonwood growth rates adjacent to the constructed side-channel chute. This information is directly applicable to pressing management and policy decisions, including strategies for acquisition of conservation land and design of habitat restoration projects.

The project was designed to incorporate geologic, hydrologic, geographic, and biologic disciplinary expertise to develop a comprehensive assessment of how management actions have affected habitats of a part of the Big Muddy National Fish and Wildlife Refuge, and how results of that assessment can be incorporated back into management and design decisions. The results have demonstrated the synergy of integrated science by uncovering landscape-scale relations affecting patterns and dynamics of flood-plain habitats that would not be apparent as a result of single-discipline approaches. We believe that the results of this study will contribute to the continued involvement of science in adaptive management, and should prove beneficial to the design of similar rehabilitation projects on the Lower Missouri River.

\section{References Cited}

Bernhardt, E.S., Palmer, M.A., Allan, J.D., Abell, R., Alexander, G., Brooks, S., Carr, J., Clayton, S., Dahm, C., Follstad Shah, J., Galat, D.L., Gloss, S., Goodwin, P., Hart, D.H., Hassett, B., Jenkinson, R., Katz, S., Kondolf, G.M., Lake, P.S., Lave, R., Meyer, J.L., O’Donnell, T.K., Pagano, L., Sudduth, E., 2005, River restoration in the United States-a national synthesis: Science, v. 308, p. 636-637.

Downs, P.W., and Kondolf, G.M., 2002, Post-project appraisals in adaptive management of river channel restoration: Environmental Management, v. 29, p. 477-496.
Jacobson, R.B., Johnson, H.E., Laustrup, M.S., D’Urso, G.J., and Reuter, J.M., 2004, Physical habitat dynamics in four side-channel chutes, Lower Missouri River: U.S. Geological Survey Open-File Report 2004-1071, 60 p., accessed February, 2006, at URL http://www.cerc.usgs.gov/pubs/MoRiver/ OFR_2004-1071.htm

Palmer, M.A., Bernhardt, E.S., Allen, J.D., Lake, P.S., Alexander, G., Brooks, S., Carr, J., Clayton, S., Dahm, C.N., Follstad Shah, J., Galat, D.L., Gloss, S., Goodwin, P., Hart, D.D., Hassett, B., Jenkinson, R., Kondolf, G.M., Lave, R., Meyer, J.L., O’Donnell, T.K., Pagano, L., and Sudduth, E., 2005, Standards for ecologically successful river restoration: Journal Of Applied Ecology, v. 42, p. 208-217. 


\section{Glossary}

A

Allostratigraphic Allostratigraphy defines map units based on recognition and delineation of their bounding discontinuities (for example, channel scours, valley scours, traceable soil horizons).

Allounit A mapping measurement unit derived from allostratigraphic techniques.

Alluvium Clay, silt, sand, gravel, or other particulate material deposited by a river or stream. Alluvial valley fill refers to these sediment deposits.

Aquatic habitat The native environment or specific surroundings where a plant or animal naturally grows or lives in, on, or near the water.

Anthropogenic Derived from human activities.

Avulsion A relatively sudden shift of the river channel to a new location leaving an abandoned channel.

B

Basal area The cross sectional area of a tree trunk or stem at breast height.

\section{C}

Cavitation Applied to tree physiology, the blockage of the sap column by a large negative water potential resulting in the infiltration of air into the xylem.

Channel Fill Alluvial sediments that have been deposited in a former river channel.

\section{D}

Deposition The accumulation of sediments because of slowing movement of transporting water.

Digital Elevation Model (DEM) A digital representation of elevation data in a raster form (see raster below). DEMs consist of a sampled array of elevations at regularly spaced intervals.

\section{E}

Erosion The wearing away and removal of earth materials by weathering, solution, corrosion, or transportation by running water, waves, moving ice, and wind currents.

Evapotranspiration The combined processes by which water is transferred from the earth's surface to the atmosphere through evaporation of water, the capillary fringe of the groundwater table, and the transpiration of ground water by plants whose roots tap the capillary fringe of the ground-water table.

Fluvial Refers to topics related to flowing water.

\section{G}

Geochronology The science of determining the age of rocks, fossils, and sediments using a variety of dating methods.

Geomorphology The study of landforms, including their origin and evolution, and the processes that shape them.

\section{H}

Holocene Epoch A geologic time extending from about 10,000 years ago to the present.

Hydroperiod The seasonal and cyclical pattern of water in a stream, river, or wetland.

L

Lithofacies A mappable subdivision of a designated stratigraphic unit based on physical sedimentary characteristics, including mineralogy and particle size distribution.

Lithology The study, description, and classification of the physical character of a rock, sediment, or geologic formation.

Landsat Thematic Mapper (TM) A satellite instrument that detects and records electromagnetic radiation from the earth; used for mapping land cover distributions.

\section{M}

Meander loop allounit An allostratigraphic unit comprising a point bar and bounding channel-fill allounits. Interpreted to record 
lateral migration of a single point bar during development of a single river meander.

Mississippian period In geologic time, the period from 360-325 million years ago.

Multi-spectral digital satellite image Satellite-based images composed from multiple bands of the visible or infrared region of electromagnetic radiation.

Optically stimulated luminescence (OSL) dating A method of establishing the age of sediments based on time elapsed since their last exposure to light prior to burial.

\section{0}

Orthophotographic image An image that has been rectified to remove distortion.

\section{$\mathbf{P}$}

Paleozoic Era The geologic eras extending from 544 to 248 million years ago.

Panchromatic image An image constructed from many discrete wavelength bands rather than individual bands; typically used to describe images produced from dedicated equipment aboard earth observation satellites.

Pedology The scientific study of soils, their origins, characteristics, and uses.

Pleistocene Epoch In geologic time, 1.8 million to approximately 10,000 years ago.

Point bar Landform on the inside of river bends where sediment accumulates as the bend migrates laterally across the valley.

Potentiometric surface Surface that represents the static head of water in an aquifer; it is defined by the altitude to which water will rise in tightly cased wells from a given point in an aquifer.

Pressure transducers Instrumentation used to measure water levels in ground-water level monitoring wells.

\section{$\mathbf{0}$}

Quaternary Period In geologic time, from 1.8 million years ago to the present, encompassing the Holocene and Pleistocene epochs.

Quasi-experiments Systematic experiments with controls and treatments, but lacking complete randomization.
R

Raster image data Spatial data acquired by a remote sensing device and expressed as a matrix of cells or pixels (an abbreviation for picture element).

Riparian Relating to the banks of a river or stream, and to associated plant and animal communities.

S

Sedimentology Study of the history and processes of sediment transport and deposition.

Seismic refraction survey A geophysical survey that utilizes the refraction of seismic waves on geologic layers and rock/soil units in order to characterize the subsurface geologic conditions and geologic structure.

Side-channel chute Secondary river channels that typically cut across a river bend.

Siliciclastic bedrock formations Rock units composed primarily of silicate mineral fragments.

Splay A typically sandy deposit formed when river water flows overbank and expands laterally, dropping its sediment.

Stochastic Characterized by random probability.

Stomata Pores in the epidermis of a leaf or stem through which gases and water vapor pass.

Strata A layer of sedimentary rock or sediment with relatively uniform composition.

Stratigraphy The branch of geology concerned with the formation, composition, ordering in time, and arrangement in space of sedimentary rocks and sediments.

Substrate Topmost layer of sediment at the bottom of a river or lake.

Surficial geology The study of sediment and soils at and near the land surface.

$\mathbf{T}$

Transmissivity The rate of water transmission through a unit width of porous sediment or rock.

Transpiration The process by which water vapor escapes from plants through the leaves to enter the atmosphere. 
Trophic level The position occupied by an organism in a food chain.

Xeric plant species A plant that requires little moisture or a habitat containing little moisture.

$\mathbf{X}$

Xylem Supporting and water-conducting tissue of vascular plants.

\section{Acronyms}

BAI Basal area increments

DEM Digital elevation model

DBH Diameter at breast height

GPS Global Positioning System

MDC Missouri Department of Conservation

NAD 83 North America Datum of 1983

NAVD 88 North America Vertical Datum of 1988

NGVD 29 National Geodetic Vertical Datum of 1929

NWIS National Water Quality Information System

OSL Optically stimulated luminescence

SWH Shallow water habitat

TM Thematic mapper

USACE U.S. Army Corps of Engineers

USFWS U.S. Fish and Wildlife Service

USGS U.S. Geological Survey 
